\title{
The sun-moths (Lepidoptera: Castniidae) of Western Australia: an inventory of distribution, larval food plants, habitat, behaviour, seasonality and conservation status
}

\author{
Andrew A.E. Williams', Matthew R. Williams², Edward D. Edwards ${ }^{3}$ \\ and Rebecca A.M. Coppen² \\ ${ }^{1}$ Department of Parks and Wildlife, Woodvale Wildlife Research Centre, Locked Bag 104, \\ Bentley Delivery Centre, Western Australia 6983, Australia. \\ 2 Department of Parks and Wildlife, Keiran McNamara Conservation Science Centre, \\ 17 Dick Perry Avenue, Kensington, Western Australia 6983, Australia. \\ ${ }^{3}$ CSIRO Australian National Insect Collection, National Research Collections Australia, \\ PO Box 1700, Canberra, Australian Capital Territory 2610, Australia. \\ *Corresponding author: andy.williams@dpaw.wa.gov.au
}

\begin{abstract}
Information on the distribution, larval food plants, habitat, behaviour, flight period and conservation status is reviewed for the following sun-moth (Castniidae) species which occur in Western Australia, arranged in order: Synemon sophia species group: Synemon catocaloides Walker 1865, Synemon leucospila Meyrick 1891, Synemon maja Strand 1911, Synemon nupta Westwood 1877, Synemon sophia White 1841, Synemon sp. 'Bob Hay', Synemon sp. nr. discalis, Synemon sp. 'Leeman', Synemon sp. 'Mount Ragged', Synemon sp. 'Perth' (species group complex), Synemon sp. 'Yarloop'. Synemon directa species group: Synemon directa Westwood 1877, Synemon sp. 'Victoria Rock'; Synemon magnifica species group: Synemon notha Westwood 1877, Synemon sp. 'Moirs Rock', Synemon sp. 'Mount Dale', Synemon sp. 'Ravensthorpe'. Synemon laeta species group: Synemon edwardsi Williams and Williams 2016, Synemon gratiosa Westwood 1877, Synemon jcaria R. Felder 1874. Synemon 'grass-feeding' species group: Synemon austera Meyrick 1891, Synemon brontias Meyrick 1891, Synemon nais Klug 1850, Synemon obscurella Westwood 1877, Synemon phaeoptila Turner 1906, Synemon wulwulam Angel 1951, Synemon sp. 'Alan Graham', Synemon sp. 'Eradu' and Synemon sp. 'Roper River'. Their phylogeny, life cycles, threats faced, management implications and future conservation are discussed.
\end{abstract}

KEYWORDS: Australia, phylogeny, species richness, flight-time triggers, hill-topping behaviour, fireprone environment

\section{INTRODUCTION}

Sun-moths belong to the Castniidae, a family of very unusual diurnal moths. They look superficially like butterflies and, as their name implies, almost invariably fly in warm to hot sunny conditions. Like butterflies, they have clubbed antennae, and in many species the hind wing is brightly coloured although the forewings are dull and cryptically marked. The monophyly of Castniidae is well supported from molecular research but the systematic position of this family is unresolved (Kallies et al. 2016). This family in all probability had its origin in southern Gondwana, and today is represented in South and Central America and Australia, as well as south-east Asia (Edwards et al. 1999). In Australia, sun-moths are found predominantly across the temperate southern parts of the continent, but also occur in the inland semi-arid zone and tropical north.

Compared with Australia's well documented butterfly fauna (Braby 2000, 2004, 2016; Orr and Kitching 2010) the continent's Castniidae are relatively poorly known. This is especially true for Western Australia, where 13 of the 29 species recognised in this paper are yet to be formally described and which represent more than half of the approximately 45 Australian species of sun-moth (Edwards 1997). At present, E. D. Edwards' (ANIC) Castniidae database and the Atlas of Living Australia 
website are the only online inventories where data on the distribution of Australian sun-moths is readily available. Even here, information on many Western Australian sun-moth species is scant.

This paper reviews the published information on the distribution, larval food plants, habitat, behaviour, flight periods and conservation status of the Western Australian sun-moths, and presents new data for many species. For each of the 29 species recorded, a set of colour photographs of specimens is given, together with maps of their distribution. The sun-moth illustrations are all presented at the same scale, so that the sizes of the different species can be compared. The data for each species includes lists of historical and previously unpublished records, and recent (2000-2016) records. A provisional determination of conservation status is given for each species. The correlation between the mouth parts of adult sun-moths (their ability to feed) and their flight times is discussed. The genetic relationships of some Western Australian sun-moth species is also discussed.

\section{METHODS}

The historical records have primarily been taken from E.D. Edwards' (ANIC) Castniidae database and the Atlas of Living Australia website. For the most part, the new information presented in this paper was gathered between 2010 and 2013, when the Western Australian Department of Parks and Wildlife conducted surveys to determine the distribution and conservation status of the graceful sun-moth Synemon gratiosa (Bishop et al. 2010a,b; Gamblin et al. 2010; Williams M. et al. 2012). During this period, the distribution, food plants and habitat preferences of two closely allied species - the claret sun-moth, Synemon jcaria (Williams A. et al. 2012, Williams and Williams 2013a,b), and the recently described splendid sun-moth, Synemon edwardsi (Williams and Williams 2013b, 2016a) — were also determined. Several other sun-moth species were studied opportunistically, primarily in the Wheatbelt, South-West and South Coast biogeographic regions (Figure 1). More recently, surveys have been extended eastwards to include the semi-arid Goldfields and the western portion of the Nullarbor Plain, and northwards into the Gascoyne, Pilbara and Kimberley (Figure 1). As a result, the Department now has a substantial sun-moth reference collection and a comprehensive database on the Western Australian Castniidae fauna (Williams and Williams 2016b). This collection will be lodged in the Western Australian Museum. Additional locality data or specimen photographs have been obtained from specimens held in the Western Australian Museum, the Australian National Insect Collection, the Northern
Territory Museum, and the private collections of Dr. Axel Kallies, Mr. Paul Hutchinson, Mr. Magnus Peterson, Mr. Tony Tomlinson and Dr. Michael Braby.

For each taxon, a provisional assessment of its conservation status is given. Specimen locality data has been used to map each taxon's distribution and determine its occurrence within Western Australia's conservation estate. Some species were found to have limited distributions, but were common and widespread where they occurred. Others had a wider distribution, but occurred only in small isolated colonies. These factors were taken into account when assessing conservation status. With the exception of $S$. gratiosa, which is already listed Federally as 'nearthreatened' and as a 'priority 4' species under Western Australian State legislation, the conservation status of these Western Australian species is listed under one of the following three headings: (1) not threatened, (2) data deficient and (3) data deficient - possibly endangered. Reasons for allocating each conservation status are given.

Nomenclature for the sun-moths follows the E.D. Edwards' (ANIC) Castniidae database and includes the provisional identification name tags allocated by E.D. Edwards for species for which formal scientific names and descriptions are yet to be published. E.D. Edwards and A. Kallies are actively working on a

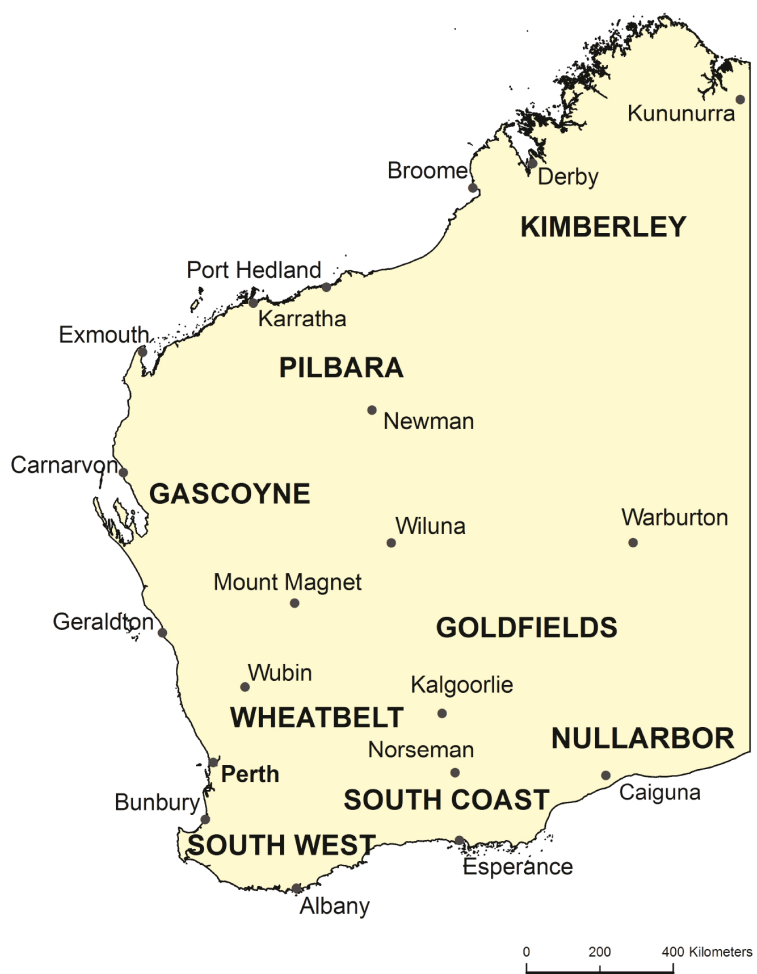

FIGURE 1 Map of Western Australia showing Major Biogeographic Regions and towns. (Source: Department of Parks and Wildlife, Science and Conservation Division) 
monograph of the Australian sun-moths in which these undescribed species will be named. In this paper the Western Australian sun-moths are placed in the species groups recognised by E.D. Edwards in his taxonomic arrangement of the Australian Castniidae (unpublished list). Within each species group the species are listed in alphabetical order, with the described taxa listed first followed by the undescribed taxa. Phrase names are not to be interpreted as establishing new species as per Article 8.3 of the Code (ICZN 1999). Plant nomenclature and common names are those current (July 2015) in FloraBase, the Department of Parks and Wildlife's online list of the Western Australian flora. Specimens listed under Historical Records are located in ANIC and those listed under Recent Records are located in WAM unless stated otherwise.

\section{ABBREVIATIONS}

The following abbreviations refer to institutional and private collections in which specimens referred to in this paper are located. Institutional collections: ANIC $=$ CSIRO Australian National Insect Collection, Canberra; WAM = Western Australian Museum, Perth; NTM $=$ Northern Territory Museum, Darwin; DAFC $=$ Western Australian Department of Agriculture and Food Collection, Perth; QM = Queensland Museum, Brisbane; BMNH = British Museum of Natural History, London; HEC = Hope Entomological Collections, Oxford University Museum of Natural History, Oxford; $\mathrm{MM}=$ Macleay Museum, Sydney; UQ = University of Queensland Collection, now in QM; AM = Australian Museum, Sydney; MNHU = Museum für Naturkunde, Berlin. Private collections: AKC = Axel Kallies Collection, Melbourne; PHC $=$ Paul Hutchinson Collection, Perth; MPC = Magnus Peterson Collection, Perth; TTC = Tony Tomlinson Collection, Exmouth; MFBC $=$ Michael Braby Collection, Canberra. Numbers with C-prefix refer to the WA Department of Parks and Wildlife Castniidae data base.

\section{FAMILY CASTNIIDAE}

\section{Synemon sophia species group}

\section{Synemon catocaloides Walker 1865 (Western Red Sun-moth)}

Figure 2

\section{BRIEF DESCRIPTION}

Synemon catocaloides is the largest of the Western Australian spring flying sun-moths. In males the average wingspan is $45 \mathrm{~mm}$, while the wingspan of some females may be $55 \mathrm{~mm}$. In both sexes, the upper side of the forewing is dull grey, with variable blackish markings. Some individuals, particularly females from the semi-arid zone, also have quite extensive white markings. The base colour on the upper side of the hind wing is dull black, with very extensive bright red bands and markings. In both sexes, the underside of the forewing is brownish-black, with two prominent red bands. In females, the innermost of these bands is broader and extends across the wing. There are also extensive red markings on the underside of the hind wing. In specimens from the northern parts of the range, the colour on the upper side of the hind wing tends to be more orange; in those found further south, more scarlet.

\section{DISTRIBUTION}

Synemon catocaloides is endemic to Western Australia. It occurs across the central and northern Wheatbelt and into the adjacent semi-arid zone. It has been recorded as far north as Meadow Station, in the Gascoyne region (ANIC Castniidae database), and as far south as Durokoppin Nature Reserve. Inland, it has been found at Latham and at Buntine Nature Reserve near Wubin, at Sandford Rock Nature Reserve, at Karroun Hill Nature Reserve and and at Southern Cross (Figure 3).

\section{LARVAL FOOD PLANT}

The larval food plant is Tussocky Cord-rush, Ecdeiocolea monostachya F. Muell. The distribution of the sun-moth closely matches that of the larval food plant.

\section{HABITAT}

This sun-moth is found in a variety of woodland and shrubland habitats where its larval food plant is often dominant in the understory.

\section{BEHAVIOUR AND FLIGHT PERIOD}

At times the sun-moth may be locally abundant, particularly in areas where E. monostachya is common. The species is known for periodic mass emergences, presumably in response to favourable weather. Males search actively among the cord-rush plants for unmated females. Gravid females oviposit in sand at the base of these plants. Over most of its range, $S$. catocaloides flies in October. North of Kalbarri, however, adults have also been recorded in August and September.

\section{CONSERVATION STATUS}

Not threatened. This species is widespread, locally common, and well represented in the conservation estate. There are 28 historical and 13 recent records.

\section{HISTORICAL RECORDS}

Swan River, location and date not recorded, $\mathrm{Mr}$ Diggles collection in BMNH; Cunderdin, 31 39' 00" S, $117^{\circ} 14^{\prime} 00^{\prime \prime}$ E, 23 Oct 1913, R. Illidge; Coorow, 29 53' $00^{\prime \prime} \mathrm{S}, 116^{\circ} 00^{\prime} 00^{\prime \prime} \mathrm{E}, 15$ Oct 1938 , collector unknown; Wongan Hills, $30^{\circ} 54^{\prime} 00^{\prime \prime} \mathrm{S}, 116^{\circ} 43^{\prime} 00^{\prime \prime} \mathrm{E}, 31$ Oct 1958, I.F.B. Common; Coorow, $29^{\circ} 53^{\prime} 00^{\prime \prime} \mathrm{S}, 116^{\circ} 01^{\prime}$ 00" E, 04 Nov 1958, I.F.B. Common; Dalwallinu, 30 
17' 00" S, $116^{\circ} 40^{\prime} 00^{\prime \prime}$ E, 11 Oct 1975, R.P. McMillan (WAM); $5 \mathrm{~km} \mathrm{SW}$ of Meadow Homestead, 26 44' 00" S, $114^{\circ} 35^{\prime}$ 00" E, 02 Oct 1976, A.M. Douglas and M.J. Douglas (WAM); $49 \mathrm{~km}$ NE of Wubin, $29^{\circ} 47^{\prime} 00^{\prime \prime} \mathrm{S}$, $117^{\circ} 00^{\prime}$ 00" E, 27 September 1981, I.D. Naumann and J.C. Cardale; Southern Cross, $31^{\circ} 13^{\prime} 00^{\prime \prime}$ S, $119^{\circ} 20^{\prime} 00^{\prime \prime}$ E, 08 Oct 1983, R.P. McMillan (WAM); $18 \mathrm{~km}$ E by S of Kalbarri, $27^{\circ} 44^{\prime} 00^{\prime \prime}$ S, $114^{\circ} 21^{\prime} 00^{\prime \prime}$ E, 19 Oct 1984 , D.C.F. Rentz; $9 \mathrm{~km}$ ENE of Kalbarri, $27^{\circ} 43^{\prime} 00^{\prime \prime} \mathrm{S}, 114^{\circ}$ 16' 00" E, 07 Oct 1990, I.F.B. Common; $49 \mathrm{~km} \mathrm{NE}$ of Wubin, $29^{\circ} 47^{\prime} 00^{\prime \prime} \mathrm{S}, 117^{\circ} 00^{\prime} 00^{\prime \prime}$ E, 08 Sep 1992, E.D. Edwards, $18 \mathrm{~km} \mathrm{SE}$ of Mullewa, $28^{\circ} 39^{\prime} 00^{\prime \prime} \mathrm{S}, 115^{\circ}$
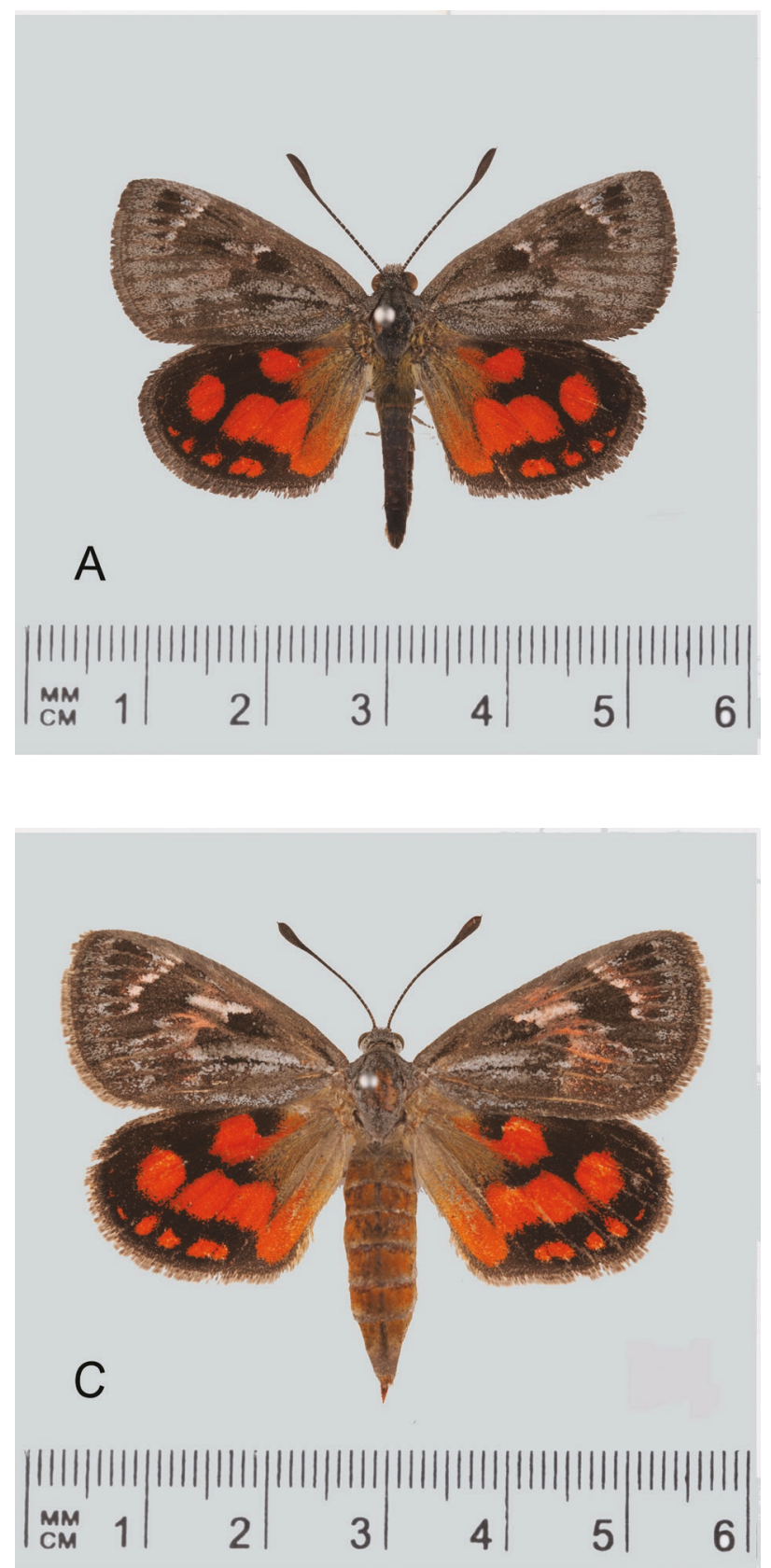

39' 00" E, 10 Oct 1992, E.D. Edwards; Tenindewa, $28^{\circ}$ 37' 00" S, $115^{\circ} 22^{\prime}$ 00" E, 11 Oct 1992, E. D. Edwards; Ambania, $28^{\circ} 41^{\prime} 00^{\prime \prime} \mathrm{S}, 115^{\circ} 22^{\prime} 00^{\prime \prime} \mathrm{E}, 11$ Oct 1992, E. D. Edwards; Loop Road, Kalbarri National Park, $27^{\circ} 41^{\prime}$ 00" S, $114^{\circ} 16^{\prime} 00^{\prime \prime}$ E, 14 Oct 1992, E. D. Edwards and E. S. Nielsen; $2 \mathrm{~km} \mathrm{SW}$ of Eneabba, $29^{\circ} 50^{\prime} 00^{\prime \prime} \mathrm{S}, 115^{\circ}$ 15' 00" E, 29 Oct 1992, E.D. Edwards and E.S. Nielsen; $44 \mathrm{~km}$ N of Galena Bridge, $27^{\circ} 26^{\prime} 00^{\prime \prime} \mathrm{S}, 114^{\circ} 40^{\prime} 30^{\prime \prime}$ E, 25 Sep 1993, M. Powell and M. Golding; Durocoppin Nature Reserve, $29^{\circ} 50^{\prime} 00^{\prime \prime} \mathrm{S}, 117^{\circ} 45^{\prime} 00^{\prime \prime}$ E, 03 Nov 1993, A.R. Main; Watheroo National Park, $30^{\circ} 07^{\prime}$ 50" S, $115^{\circ}$ 50' 40" E, 11 Oct 1994, M.R. Williams;
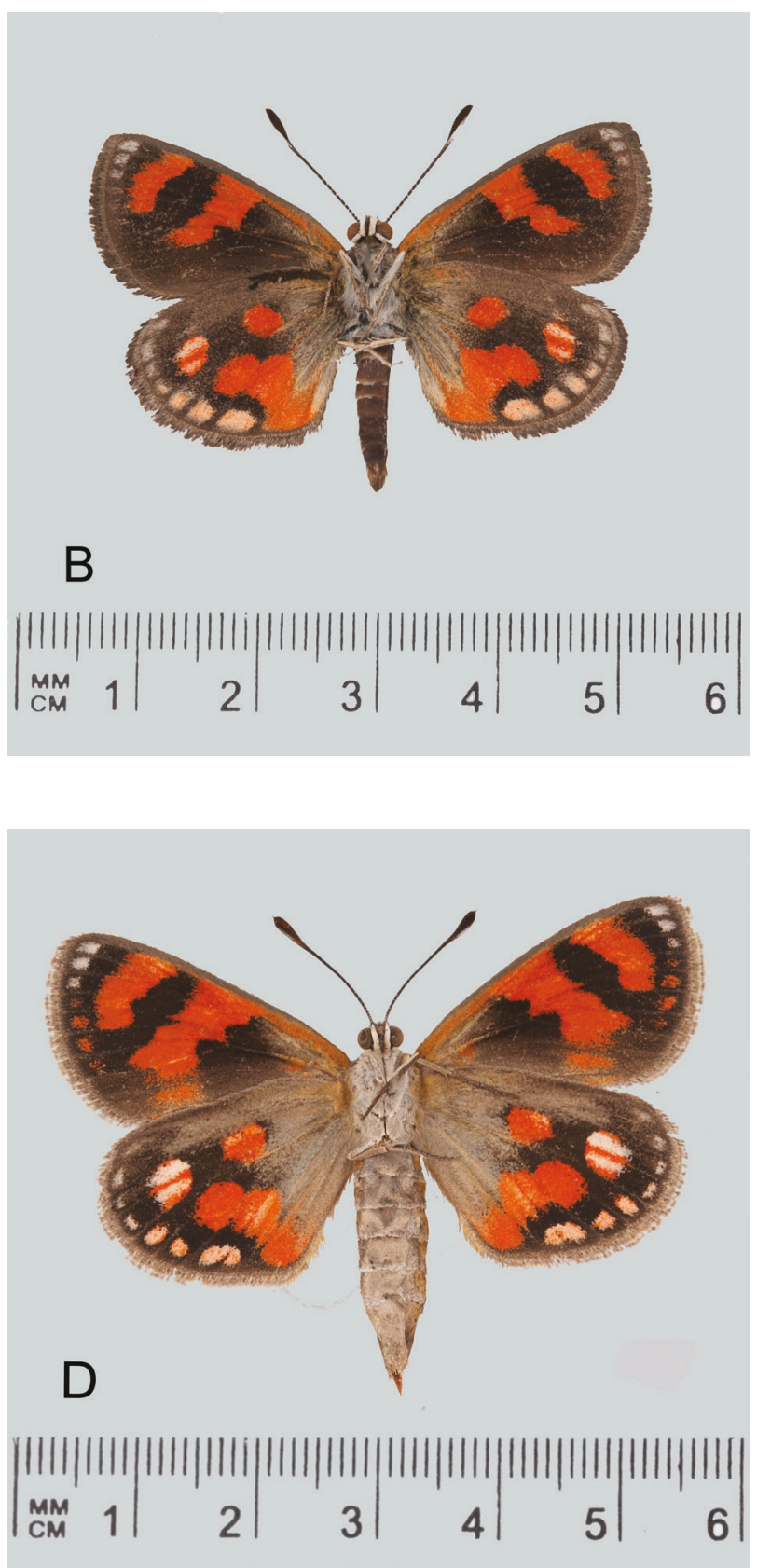

FIGURE 2 Synemon catocaloides. A, ô Dorsal; B, ô Ventral (C2745) Western Australia, Wubin (WAM); C, 9 Dorsal; D, o Ventral (C0725) Western Australia, Indarra Spring Nature Reserve (WAM). (Photos: Brian Hanich, Western Australian Museum.) 


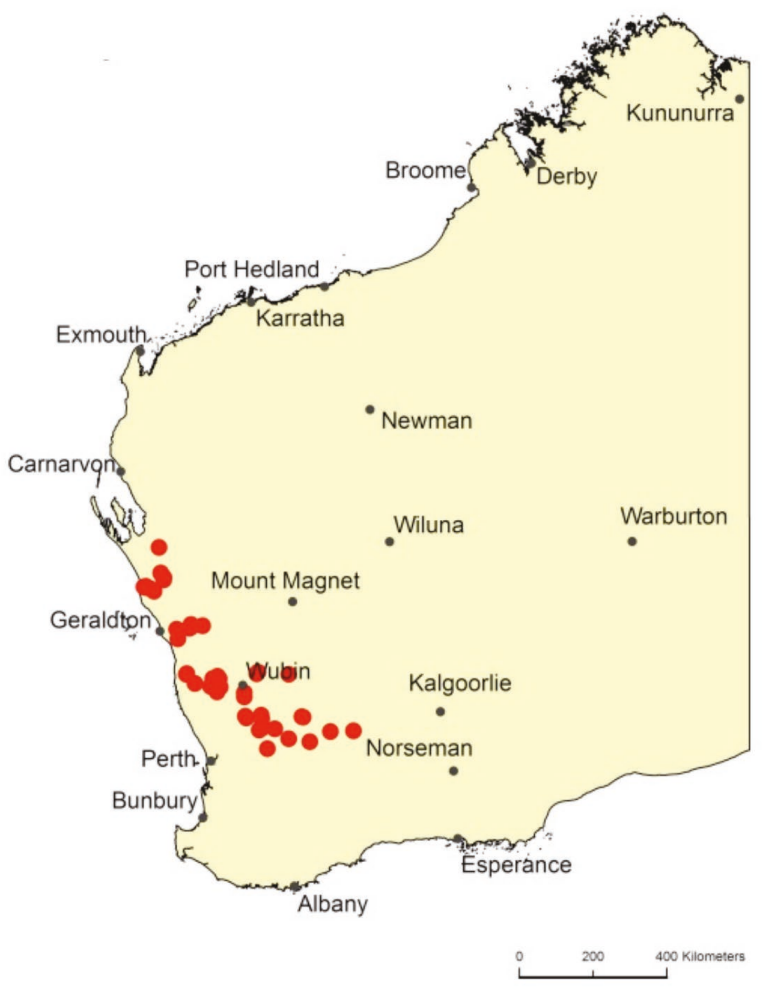

FIGURE 3 Map of Western Australia showing distribution of Synemon catocaloides.

Watheroo National Park, $30^{\circ} 16^{\prime} 00^{\prime \prime} \mathrm{S}, 116^{\circ} 00^{\prime} 00^{\prime \prime}$ E, 13 Oct 1994, A.A.E. Williams; $56 \mathrm{~km} \mathrm{~N}$ of Murchison Crossing, $27^{\circ} 21^{\prime} 22^{\prime \prime} \mathrm{S}, 114^{\circ} 37^{\prime}$ 38" E, 03 Aug 1995, M.R. Williams; $5 \mathrm{~km}$ NNE of Eurardy Homestead, $27^{\circ} 31^{\prime} 45^{\prime \prime} \mathrm{S}, 114^{\circ} 41^{\prime}$ 53" E, 04 Oct 1997, T.F. Houston (WAM); Meanarra Junction, Kalbarri, $27^{\circ} 42^{\prime} 00^{\prime \prime} \mathrm{S}$, $14^{\circ} 13^{\prime} 00^{\prime \prime}$ E, 04 Oct 1999, L. Kaila; Dowerin, 31 ${ }^{\circ} 12^{\prime}$ $00^{\prime \prime} \mathrm{S}, 117^{\circ} 02^{\prime} 00^{\prime \prime} \mathrm{E}$, date not recorded, L.J. Newman (DAFC); Merredin, 31 ${ }^{\circ} 29^{\prime} 00^{\prime \prime} \mathrm{S}, 118^{\circ} 16^{\prime} 00^{\prime \prime} \mathrm{E}$, date not recorded, L.J. Newman; South Eneabba Nature Reserve, $29^{\circ} 49^{\prime} 00^{\prime \prime} \mathrm{S}, 115^{\circ} 16^{\prime} 00^{\prime \prime} \mathrm{E}$, date not recorded, R.P. McMillan; Pithara, $30^{\circ} 23^{\prime} 00^{\prime \prime} \mathrm{S}, 116^{\circ} 40^{\prime} 00^{\prime \prime} \mathrm{E}$, date not recorded, collector unknown.

\section{RECENT RECORDS}

Wyalkatchem Nature Reserve, $31^{\circ} 10^{\prime} 14^{\prime \prime} \mathrm{S}, 117^{\circ} 24^{\prime}$ 49" E, 20 Oct 2006, A.A.E. Williams; Manmanning Nature Reserve, $30^{\circ} 54^{\prime} 49^{\prime \prime} \mathrm{S}, 117^{\circ} 05^{\prime} 38^{\prime \prime} \mathrm{E}, 30$ Oct 2009,A.A.E. Williams; Amery Nature Reserve, 31 09' 01" S, $117^{\circ} 05^{\prime} 47^{\prime \prime}$ E, 30 Oct 2009, A.A.E. Williams; Manmanning Dam Nature Reserve, 30 49' 55" S, $17^{\circ}$ 04' 52" E, 30 Oct 2009, A.A.E. Williams; Capamauro Nature Reserve, $29^{\circ} 56^{\prime} 18^{\prime \prime} \mathrm{S}, 115^{\circ}$ 54' 09" E, 07 Oct 2010, A.A.E. Williams; Indarra Spring Nature Reserve, $28^{\circ} 42^{\prime} 42^{\prime \prime} \mathrm{S}, 115^{\circ} 1^{\prime}$ 50" E, 09 Oct 2010, A.A.E. Williams; Wicherina Reserve, E of Geraldton, $28^{\circ} 44^{\prime}$ 00" S, 115 01' 02" E, 09 Oct 2010, A.A.E. Williams; Burma Road Nature Reserve, $28^{\circ} 58^{\prime} 12^{\prime \prime} \mathrm{S}, 115^{\circ} 02^{\prime}$ 44" E, 09 Oct 2010, A.A.E. Williams; Marchagee
Nature Reserve, $29^{\circ} 56^{\prime} 33^{\prime \prime} \mathrm{S}, 116^{\circ} 03^{\prime} 32^{\prime \prime} \mathrm{E}, 16$ Oct 2010, A.A.E. Williams; Barbalin Nature Reserve, $30^{\circ}$ 52' 51" S, $118^{\circ} 06^{\prime} 25^{\prime \prime}$ E, 18 Oct 2010, T. Gamblin; Sandford Rock Nature Reserve, $31^{\circ} 13^{\prime} 58^{\prime \prime} \mathrm{S}, 118^{\circ}$ 46' 13" E, 19 Oct 2010, A.A.E. Williams; Durokoppin Nature Reserve, $31^{\circ} 24^{\prime} 28^{\prime \prime} \mathrm{S}, 117^{\circ} 45^{\prime} 03^{\prime \prime} \mathrm{E}, 18$ Oct 2010, A.A.E. Williams; Elphin Nature Reserve, $30^{\circ} 51^{\prime}$ 41" S, $116^{\circ} 41^{\prime} 42^{\prime \prime}$ E, 26 Oct 2010, A.A.E. Williams; $100 \mathrm{~km} \mathrm{~N}$ of Northampton, $27^{\circ} 28^{\prime} 18^{\prime \prime} \mathrm{S}, 114^{\circ} 42^{\prime} 23^{\prime \prime}$ E, 08 Sep 2011, A.A.E. Williams; Kalbarri National Park, $27^{\circ} 48^{\prime}$ 26" S, 114 27' 59" E, 08 Sep 2011, A.A.E. Williams; Nature Reserve at Gunyidi, $30^{\circ} 08^{\prime} 54^{\prime \prime} \mathrm{S}$, $116^{\circ} 04^{\prime} 47^{\prime \prime}$ E, 11 Oct 2011, A.A.E. Williams; 46 km NE of Wubin, 29 49' 14" S, $116^{\circ} 58^{\prime} 09^{\prime \prime}$ E, 01 Oct 2012, A.A.E. Williams and E.P. Williams; Wundowlin Nature Reserve, $30^{\circ} 52^{\prime} 16^{\prime \prime} \mathrm{S}, 118^{\circ} 04^{\prime} 32^{\prime \prime}$ E, 08 Oct 2012, A.A.E. Williams and M.R. Williams; Eurardy Station (photograph), $27^{\circ} 39^{\prime} 15^{\prime \prime}$ S, 114 43' 58" E, 09 Sep 2014, V. Westcott; Nature Reserve at Gunyidi, $30^{\circ}$ $08^{\prime} 54^{\prime \prime}$ S, $116^{\circ} 04^{\prime} 47^{\prime \prime}$ E, 16 Oct 2015, A.A.E. Williams; Alexander Morrison National Park, 30 03' 37" S, $115^{\circ}$ 27' 39" E, 16 Oct 2015, A.A.E. Williams; Karroun Hill Nature Reserve, $30^{\circ} 14^{\prime} 34^{\prime \prime}$ S, $118^{\circ} 23^{\prime}$ 59" E, 10 Oct 2016, A.A.E. Williams and M.R. Williams; Buntine Water Reserve (photograph), 29 $9^{\circ} 58^{\prime} 53^{\prime \prime} \mathrm{S}, 116^{\circ} 34^{\prime}$ 10" E, 16 Oct 2016, F. Hort and J. Hort; Buntine Water Reserve, 29 58' 54" S,116 ${ }^{\circ} 34^{\prime} 1^{\prime \prime}$ E, 19 Oct 2016, A.A.E. Williams; Buntine Nature Reserve, $29^{\circ} 58^{\prime}$ 49" S, $116^{\circ} 37^{\prime}$ 05" E, 19 Oct 2016, A.A.E. Williams; Latham, $41 \mathrm{~km} \mathrm{NNW}$ of Wubin, $29^{\circ} 44^{\prime} 54^{\prime \prime} \mathrm{S}, 116^{\circ} 27^{\prime}$ 06" E, 19 Oct 2016, A.A.E. Williams.

\section{Synemon leucospila Meyrick 1891 (White-spotted Sun-moth)}

Figure 4

\section{BRIEF DESCRIPTION}

This is a medium sized sun-moth with slightly rounded wings. In both sexes, the upper side of the forewing is patterned with black, grey and white markings, with the white markings being more pronounced in females. The upper side of the hind wing is blackish, with a series of distinct white or creamy-white spots, including a white or creamy-white discal spot. The underside is grey to blackish-grey, the forewing with two distinct broad whitish bands. In both sexes, the innermost of these bands generally extends across the wing. A line of cream-white terminal spots runs along the outer edge of the forewing. The hind wing pattern is similar to that above, but paler.

\section{DISTRIBUTION}

Synemon leucospila is a Western Australian endemic, with a near-coastal distribution from near Perth north to Kalbarri (Figure 5). 


\section{LARVAL FOOD PLANT}

The larval food plant at Howatharra Nature Reserve is Lepidosperma tenue, a species restricted to the northern part of the south-western region. Voucher specimens of this sedge have been lodged in the Western Australian Herbarium.

\section{HABITAT}

In Kalbarri National Park, S. leucospila is found in open low heath where numerous sedge species occur. At Howatharra Nature Reserve the species is found on vegetated rocky hillsides, while at Lake Logue Nature
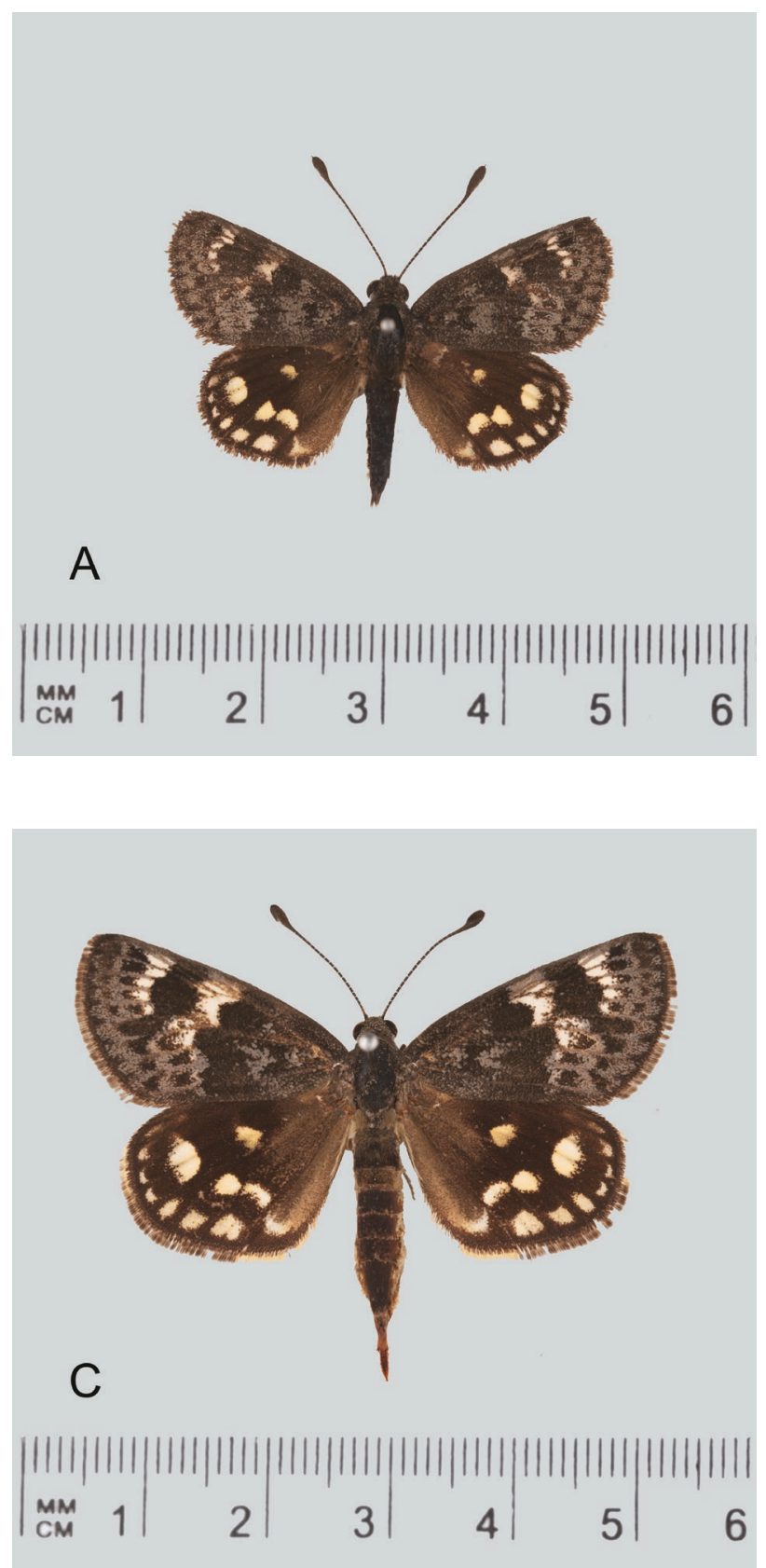

Reserve it occurs in winter-wet areas with low shrubs and sedges. At Bartlett's Well Nature Reserve the species is locally common in an area of very open Marri (Corymbia calophylla) woodland where a Mesomelaena sp. sedge is common in the low shrub understory.

\section{BEHAVIOUR AND FLIGHT PERIOD}

Synemon leucospila is a relatively slow flying species. Adults are active in sunny conditions. The males do not appear to establish individual territories but course close to the ground over areas of heath and sedges. Females are less active than males and are usually
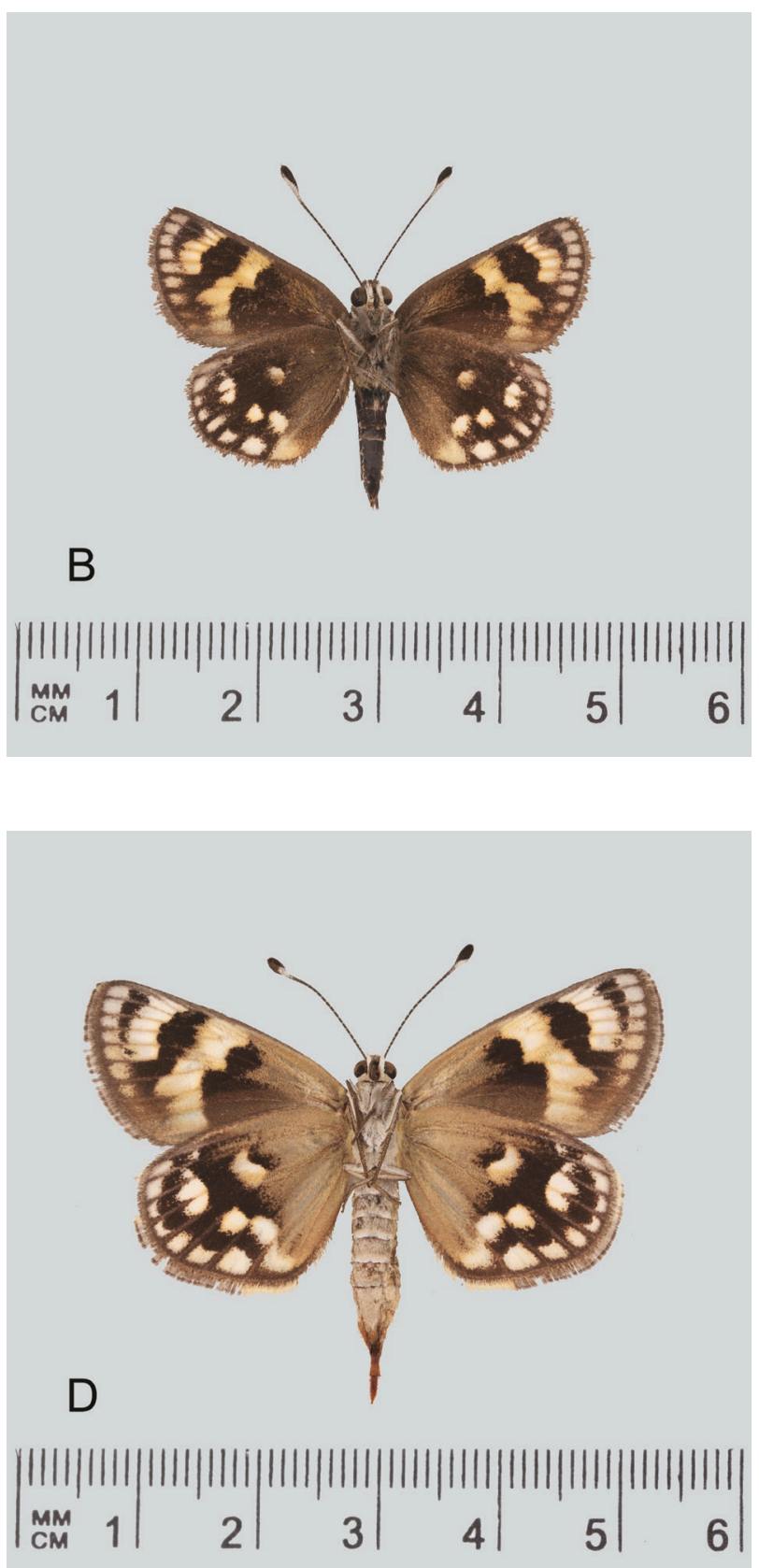

FIGURE 4 Synemon leucospila. A, ô Dorsal; B, đ̂ Ventral (C0808) Western Australia, Kalbarri National Park (WAM); C, o Dorsal; D, o Ventral (C0807) Western Australia, Kalbarri National Park (WAM). (Photos: Brian Hanich, Western Australian Museum.) 


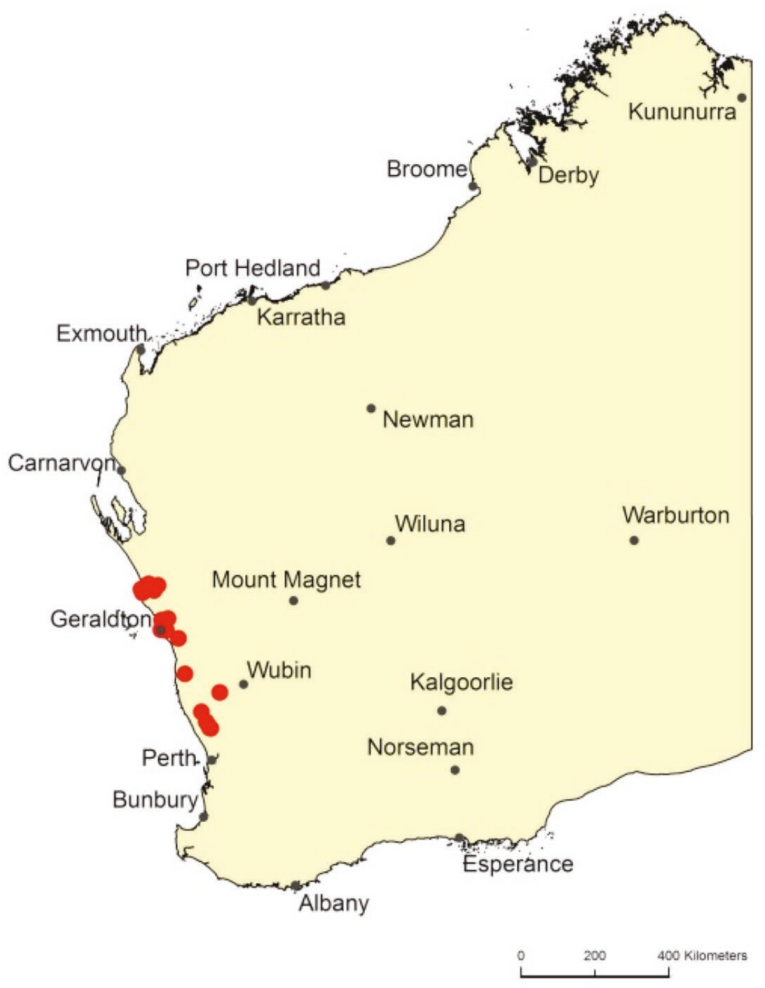

FIGURE 5 Map of Western Australia showing distribution of Synemon leucospila.

seen near sedges. At Howatharra Nature Reserve, this spring flying sun-moth often visits flowers including Verticordia spp. and Waitzia suaveolens. It flies from mid October to mid November.

\section{CONSERVATION STATUS}

Not threatened. This species is widespread, locally common, and well represented in the conservation estate. There are 16 historical and 14 recent records.

\section{HISTORICAL RECORDS}

Geraldton (general), $28^{\circ} 46^{\prime} 00^{\prime \prime} \mathrm{S}, 114^{\circ} 37^{\prime} 00^{\prime \prime}$ E, 01 Novr 1886, E. Meyrick (BMNH); Moonyoonooka, $28^{\circ}$ 46' 48" S, 114 43' 12" E, 07 Nov 1912, G.F. Berthoud; Watheroo, 30 $18^{\prime} 00^{\prime \prime} \mathrm{S}, 116^{\circ} 03^{\prime} 00^{\prime \prime}$ E, 08 Nov 1912, G.F. Berthoud; Moonyoonooka near Geraldton, 28 47' 00" S, 114 45' 00" E, 09 Nov 1913, G.F. Berthoud (AM); Kalbarri National Park, $27^{\circ} 41^{\prime}$ 00" S, 114 33' 00" E, 06 Nov 1968, N. McFarland; Moresby Range, Howatharra, $28^{\circ} 32^{\prime} 00^{\prime \prime} \mathrm{S}, 114^{\circ} 38^{\prime} 00^{\prime \prime} \mathrm{E}, 22$ Oct 1977, N. McFarland; $30 \mathrm{~km}$ NNE of Geraldton, $28^{\circ} 33^{\prime} 00^{\prime \prime} \mathrm{S}, 114^{\circ} 40^{\prime} 00^{\prime \prime} \mathrm{E}$, 15 Nov 1977, N. McFarland; $20 \mathrm{~km}$ E by S of Kalbarri, $27^{\circ} 45^{\prime} 00^{\prime \prime} \mathrm{S}, 114^{\circ} 22^{\prime} 00^{\prime \prime}$ E, 19 Oct 1984, D.C.F. Rentz; $17 \mathrm{~km} \mathrm{~S}$ of Kalbarri, $27^{\circ} 52^{\prime} 00^{\prime \prime} \mathrm{S}, 115^{\circ} 10^{\prime} 00^{\prime \prime} \mathrm{E}, 20$ Oct 1984, D.C.F. Rentz; Bartlett's Well Nature Reserve, $31^{\circ} 10^{\prime} 03^{\prime \prime} \mathrm{S}, 115^{\circ} 48^{\prime} 16^{\prime \prime}$ E, 19 Nov 1991, T.F. Houston (WAM); Loop Road, Kalbarri National Park, 27 41' 00" S, $114^{\circ} 16^{\prime} 00^{\prime \prime}$ E, 14 Oct 1992, E.D. Edwards and E.S. Nielsen; Loop Road, Kalbarri National Park, 27³9' 00"
S, $114^{\circ} 19^{\prime}$ 00" E, 16 Oct 1992, E.D. Edwards and E.S. Nielsen; Near Howatharra Hill, $28^{\circ} 33^{\prime} 00^{\prime \prime}$ S, $114^{\circ} 39^{\prime}$ 00" E, 28 Oct 1992, E.D. Edwards and E.S. Nielsen; 7

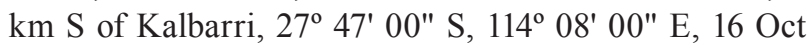
1992, E.D. Edwards and E.S.Nielsen; Kalbarri National Park, $27^{\circ} 43^{\prime} 30^{\prime \prime}$ S, 114 19' 52" E, 03 Oct 1995, M.R. Williams; Nabawa, NNE of Geraldton, $28^{\circ} 30^{\prime} 00^{\prime \prime} \mathrm{S}$, $114^{\circ}$ 47' 30" E, 14 Nov 1998, S.R. Patterson (WAM).

\section{RECENT RECORDS}

Moore River National Park, $31^{\circ} 06^{\prime} 10^{\prime \prime} \mathrm{S}, 115^{\circ} 46^{\prime} 13^{\prime \prime}$ E, 09 Nov 2009, A.A.E. Williams; Howatharra Nature Reserve, $28^{\circ} 32^{\prime}$ 52" S, $114^{\circ} 39^{\prime}$ 56" E, 10 Nov 2009, A.A.E. Williams; Lake Logue Nature Reserve, $29^{\circ} 50^{\prime}$ $50^{\prime \prime}$ S, $115^{\circ} 12^{\prime} 22^{\prime \prime}$ E, 10 Nov 2009, A.A.E. Williams; Kalbarri National Park, $27^{\circ} 48^{\prime}$ 50" S, 114 26' 59" E, 11 Nov 2009, A.A.E. Williams; N of Moore River National Park, 31 01' 04" S, $115^{\circ} 43^{\prime}$ 13" E, 13 Nov 2009, A.A.E. Williams; Burma Road Nature Reserve, $28^{\circ} 58^{\prime} 46^{\prime \prime} \mathrm{S}$, $115^{\circ} 02^{\prime} 44^{\prime \prime}$ E, 09 Oct 2010, A.A.E. Williams; Kalbarri National Park, $27^{\circ} 39^{\prime} 53^{\prime \prime}$ S, $114^{\circ} 17^{\prime} 34^{\prime \prime}$ E, 11 Oct 2010, A.A.E. Williams; Yandin Nature Reserve, 30 46' 23" S, 115 36' 15" E, 23 Oct 2010, A.A.E. Williams; Boonanaring Nature Reserve, $31^{\circ} 10^{\prime} 46^{\prime \prime} \mathrm{S}, 115^{\circ} 50^{\prime}$ 04" E, 23 Oct 2010, A.A.E. Williams; Bartlett's Well Nature Reserve, $31^{\circ} 10^{\prime} 03^{\prime \prime} \mathrm{S}, 115^{\circ} 48^{\prime} 16^{\prime \prime}$ E, 23 Oct 2010, A.A.E. Williams; ENE of Howatharra Nature Reserve, 28 31' 59" S, 114 44' 13" E, 23 Oct 2013, A.A.E. Williams; Kalbarri National Park — Euardy boundary, $27^{\circ} 32^{\prime}$ 57" S, $114^{\circ} 31^{\prime} 41^{\prime \prime}$ E, 04 Nov 2014, A.A.E. Williams; Brand Highway, Red Gully Creek, $31^{\circ}$ $05^{\prime} 08^{\prime \prime}$ S, $115^{\circ} 45^{\prime} 46^{\prime \prime}$ E, 26 Oct 2015, A.A.E. Williams; Howatharra Nature Reserve, $28^{\circ} 32^{\prime} 53^{\prime \prime} \mathrm{S}, 114^{\circ} 39^{\prime} 58^{\prime \prime}$ E, 20 Oct 2016, A.A.E. Williams.

\section{Synemon maja Strand 1911 (Major Sun-moth)}

Figure 6

\section{BRIEF DESCRIPTION}

This is a medium to large sun-moth. Males have a wingspan ranging from 35 to $45 \mathrm{~mm}$, females have a wingspan of approximately $45 \mathrm{~mm}$. In both sexes, the upper side of the forewing is grey, with broad irregular subapical and posmedian whitish bands edged with blackish grey. These pale forewing bands are distinctive and become even more pronounced in worn specimens. The upper side of the hind wing is blackish, with a bold pattern of large yellow to orange-yellow markings. The underside pattern of both wings is similar to the upper side, but the bands and spots are yellow or whitishyellow.

\section{DISTRIBUTION}

Synemon maja is a Western Australian endemic. Most specimens have been recorded from two sites inland from Geraldton: near Howatharra Hill, $25 \mathrm{~km}$ north- 
north-east of Geraldton, and at Canna Silo (Leda Nature Reserve), $120 \mathrm{~km}$ east-south-east of Geraldton. A few specimens provisionally identified as $S$. maja (ANIC Castniidae database) have also been collected west of Quairading, in the central Wheatbelt (Figure 7).

\section{LARVAL FOOD PLANT}

The larval food plant has not been identified.

\section{HABITAT}

At Howatharra Nature Reserve the habitat is species rich heath and sedge growing on rocky hillsides. At
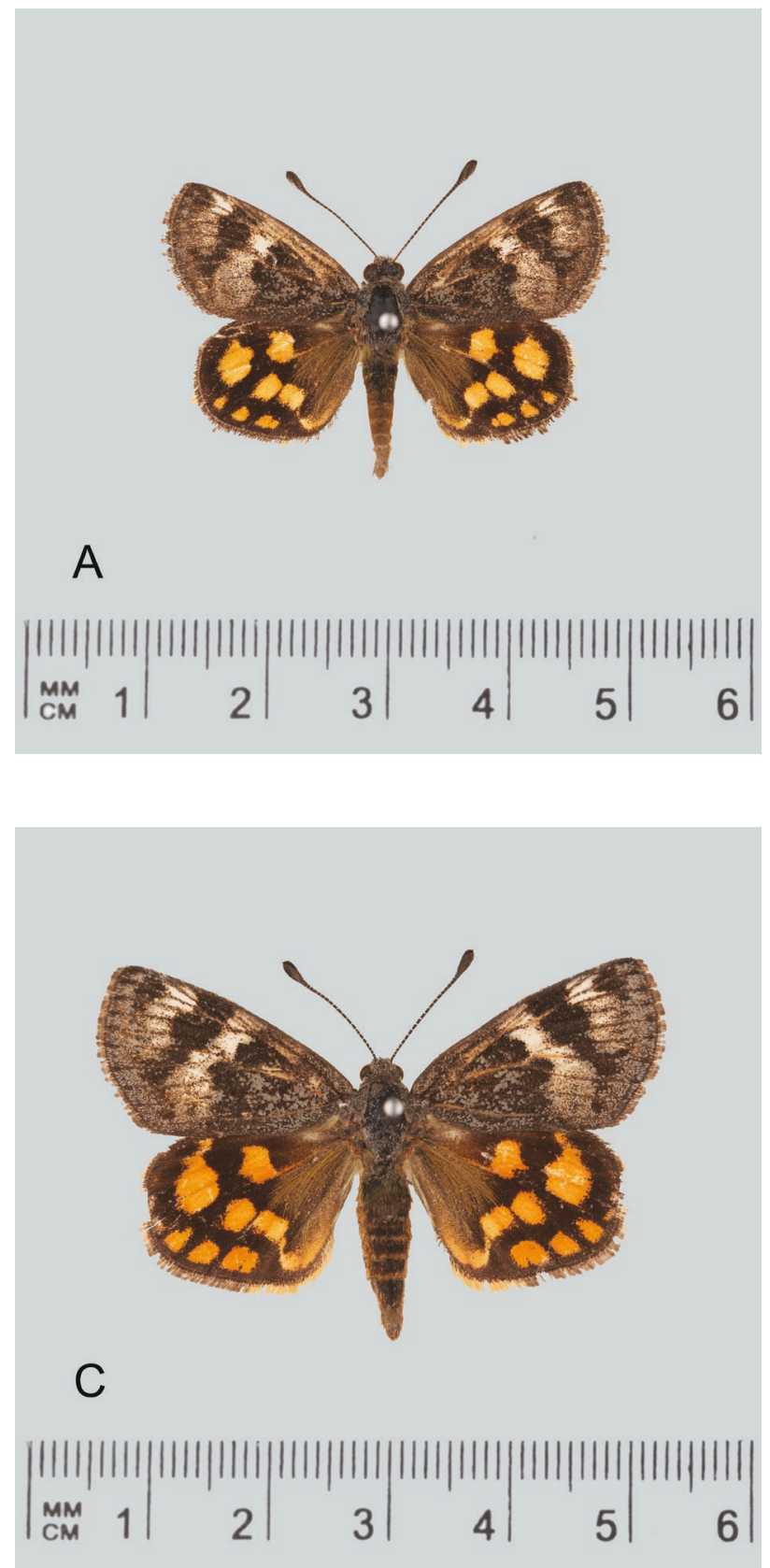

Cana Silo (Leda Nature Reserve), the habitat is Acaciadominated woodland over patches of large, fine-leafed tussock sedge.

\section{BEHAVIOUR AND FLIGHT PERIOD}

Synemon maja flies slowly amongst shrubs and sedges on the hillsides at Howatharra Nature Reserve. The likely food plant there is a large broad-leafed sedge (E.D. Edwards, personal communication, 2010). Adults also feed readily at flowers of Verticordia sp. shrubs. The flight period is October to early November.
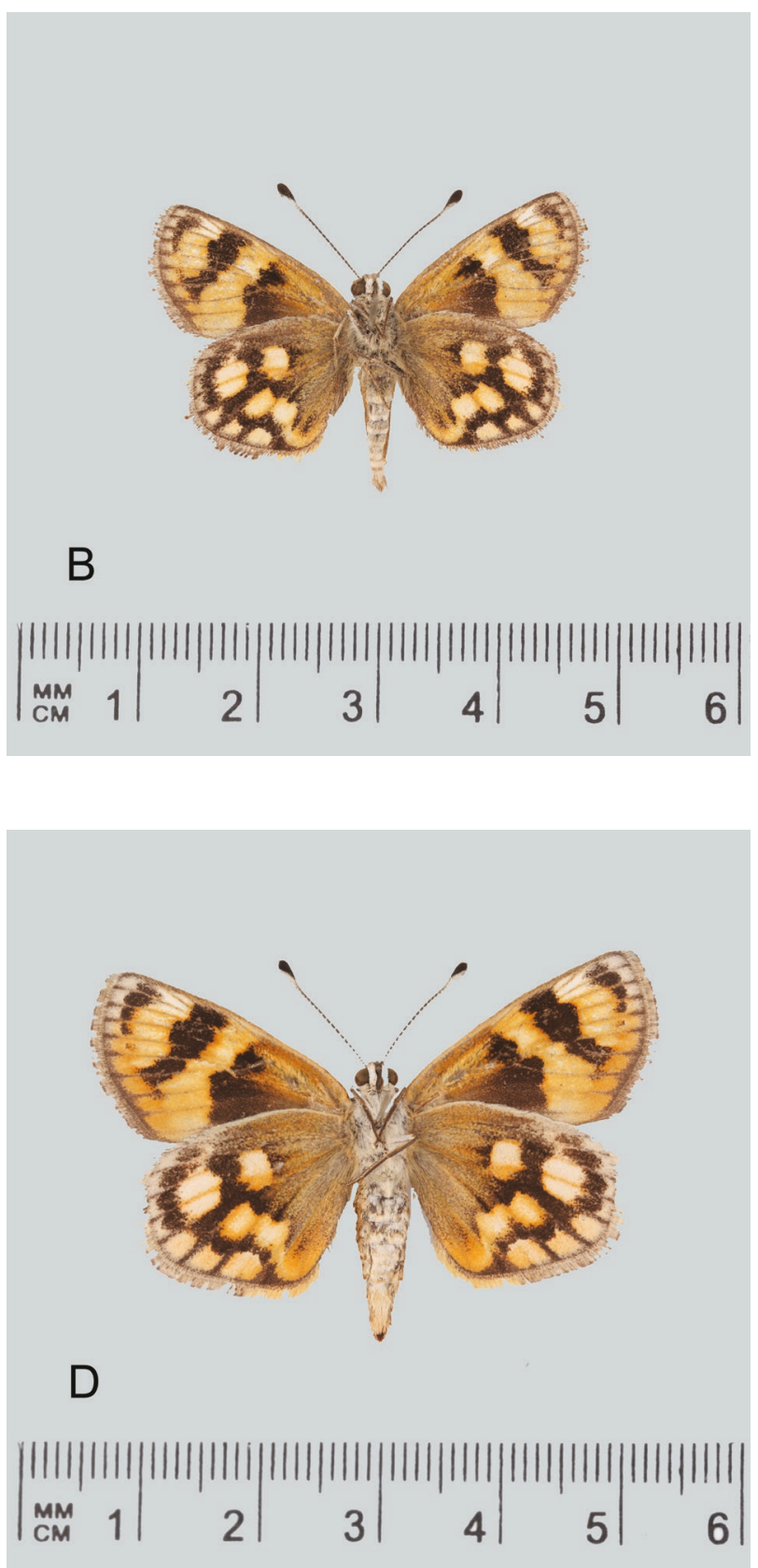


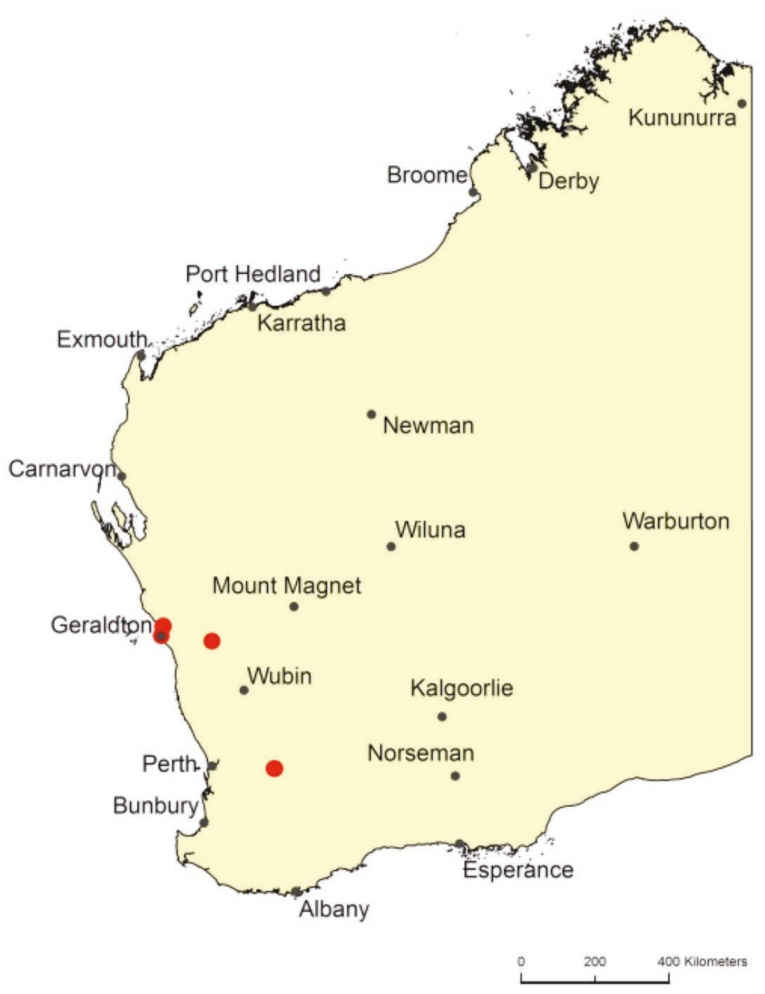

FIGURE 7 Map of Western Australia showing distribution of Synemon maja.

\section{CONSERVATION STATUS}

Data deficient. Synemon maja has a limited distribution, and is presently known only from two small nature reserves east of Geraldton, and from remnant bushland west of Quairading in the central Wheatbelt. There are few specimens in collections, even though the species flies in spring. Insufficient surveys have been conducted to accurately determine the species' conservation status. There are six historical and one recent records.

\section{HISTORICAL RECORDS}

Geraldton (general), $28^{\circ} 46^{\prime} 00^{\prime \prime} \mathrm{S}, 114^{\circ} 37^{\prime} 00^{\prime \prime}$ E, 05 Nov 1886, E. Meyrick (BMNH); $2 \mathrm{~km} \mathrm{~W}$ of Quairading, 32 01' 00" S, $117^{\circ} 23^{\prime} 00^{\prime \prime}$ E, 11 Oct 1987, R.P. Field (MV); $5 \mathrm{~km} \mathrm{~W}$ of Quairading, 32 01' 00" S, $117^{\circ} 22^{\prime}$ 00" E, 01 Nov 1992, E.D. Edwards and E.S. Nielsen; Canna Silo (Leda Nature Reserve), $28^{\circ}$ 54' 00" S, $115^{\circ} 51^{\prime} 00^{\prime \prime}$ E, 10 Oct 1992, E.D. Edwards; Howatharra Hill Reserve, $28^{\circ} 32^{\prime} 00^{\prime \prime} \mathrm{S}, 114^{\circ} 40^{\prime} 00^{\prime \prime}$ E, 12 Oct 1992, E.D. Edwards and E.S. Nielsen; Near Howatharra Hill, $28^{\circ} 33^{\prime} 00^{\prime \prime}$ S, $114^{\circ} 39^{\prime} 00^{\prime \prime}$ E, 12 Oct 1992, E.D. Edwards, E.S. Nielsen.

\section{RECENT RECORDS}

Howatharra Nature Reserve, $28^{\circ} 32^{\prime} 52^{\prime \prime} \mathrm{S}, 114^{\circ} 39^{\prime}$ 49" E, 09 Oct 2010, A.A.E. Williams.

\section{Synemon nupta Westwood 1877 (Ruby Sun-moth)}

Figure 8

\section{BRIEF DESCRIPTION}

Synemon nupta is a large sun-moth. Males have an average wingspan of $40 \mathrm{~mm}$; females are larger, and may have a wingspan approaching $55 \mathrm{~mm}$. The upper side of the forewing is grey, with variable blackish and white markings. Some individuals have quite extensive white markings, particularly females from the semi-arid zone. The upper side of the hind wing is predominantly black, with the basal area a rich, dark ruby-red, or (rarely) orange-yellow. The underside of the wings is mostly black, with some restricted dark red markings on the forewing and white spotting on the hind wing. In flight the ruby sun-moth always appears dark.

\section{DISTRIBUTION}

This sun-moth is a Western Australian endemic. It has a south-western distribution, excluding the extreme southwest corner of the State, and occurs predominantly within the Wheatbelt region. Isolated populations also occur in the Jarrah (Eucalyptus marginata) forest east of Perth. Specimens have previously been recorded at Gleneagles, east of Perth; Gabbin, east of Koorda; southwards to Lake Grace and Ravensthorpe; and eastwards to Grasspatch (ANIC Castniidae database). Recent records extend the species' range north to Elphin Nature Reserve near Wongan Hills, south to Cocanarup Reserve near Ravensthorpe, and east to Burra Rock and Queen Victoria Rock in the semi-arid zone, as well as 'The Diamonds Hill' in Cape Arid National Park (Figure 9).

\section{LARVAL FOOD PLANT}

The larval food plant on the inland sandy plains between Yellowdine and Coolgardie, in the northeastern part of the species range, is Lepidosperma rigidulum (Kuk.) K.L. Wilson. This plant has a wide range that matches that of $S$. nupta fairly well.

\section{HABITAT}

Synemon nupta is found in a variety of habitats. The westernmost localities are within Jarrah forest east of Perth. Here, the sun-moths are usually found near the base of large granite outcrops with surrounding heath and sedgeland. In the Wheatbelt, S. nupta occurs in species rich heath and in sedgeland. At Queen Victoria Rock and Burra Rock, in the semi-arid zone, the species is found in patchy mallee and Tamma (Allocasuarina campestris) shrubland over mixed sedges, on yellow sandplains.

\section{BEHAVIOUR AND FLIGHT PERIOD}

In open heath and sedgeland habitats, males fly close to the ground. They do not appear to establish territories 
but course over large areas of breeding habitat in search of unmated females. They periodically settle, on low shrubs, sticks, or on the ground. Females are less frequently seen, and are usually active round the bases of their sedge larval food plants. Where the large sedge L. rigidulum is common alongside the Great Eastern Highway between Yellowdine and Coolgardie, the sunmoth is often abundant in October. The flight period varies with location: in more northern localities, ruby sun-moths appear in October; further south, they emerge later. In the Jarrah forest, near Perth, $S$. nupta has been recorded in December and January.
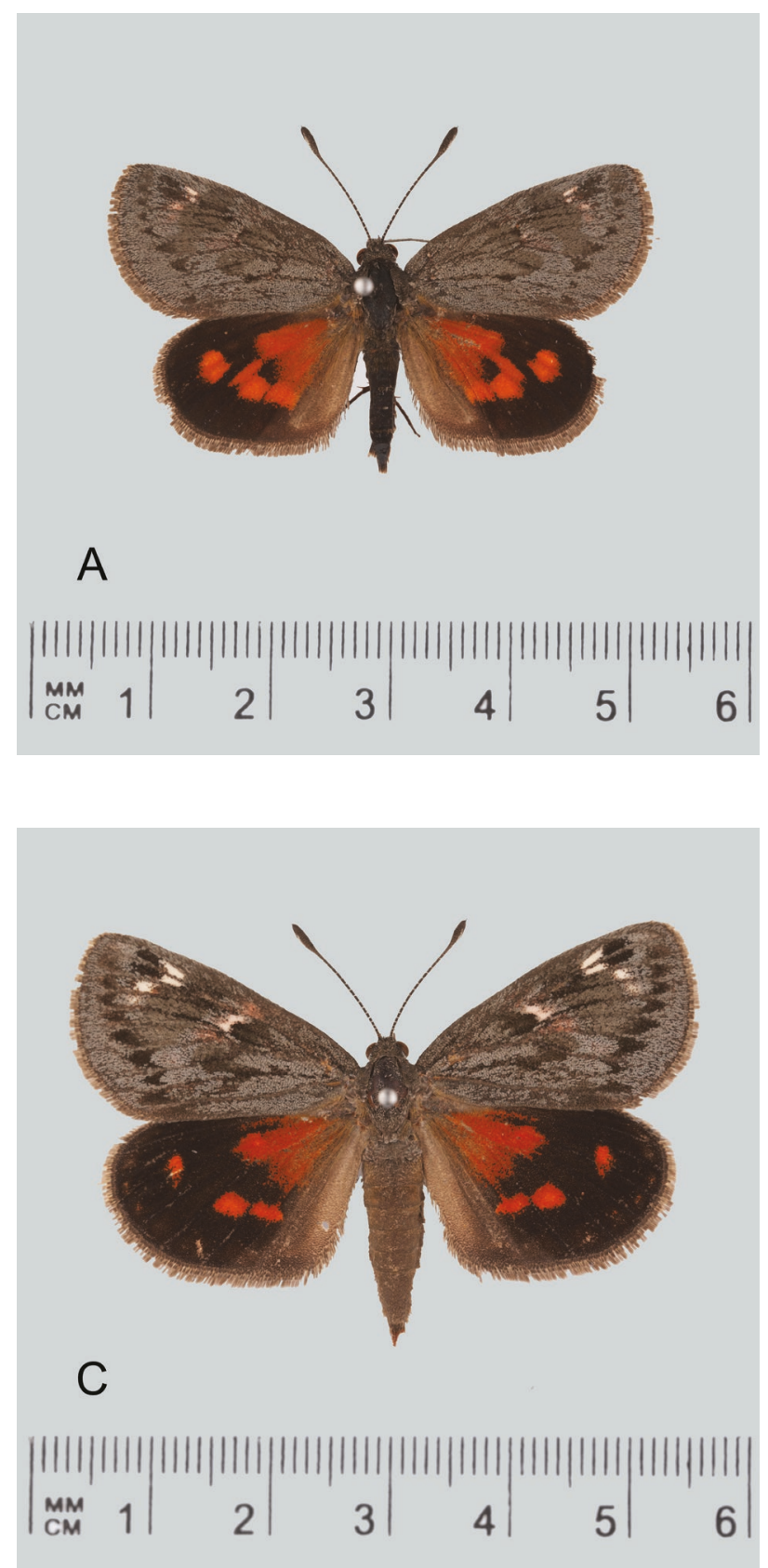

\section{CONSERVATION STATUS}

Not threatened. This species is widespread, locally common, and well represented in the conservation estate. There are 25 historical and 33 recent records.

\section{HISTORICAL RECORDS}

Western Australia, location and date not recorded, collector unknown (HEC); Kellerberrin, $31^{\circ} 38^{\prime} 00^{\prime \prime} \mathrm{S}$, $117^{\circ} 43^{\prime} 00^{\prime \prime} \mathrm{E}$, date not recorded, collector unknown (WAM); Kukerin, $33^{\circ} 12^{\prime} 00^{\prime \prime} \mathrm{S}, 117^{\circ} 43^{\prime} 00^{\prime \prime} \mathrm{E}$, date not recorded, collector unknown; Tammin, 31 $37^{\prime} 48^{\prime \prime} \mathrm{S}$, $117^{\circ} 28^{\prime} 48^{\prime \prime} \mathrm{E}$, date not recorded, collector unknown;
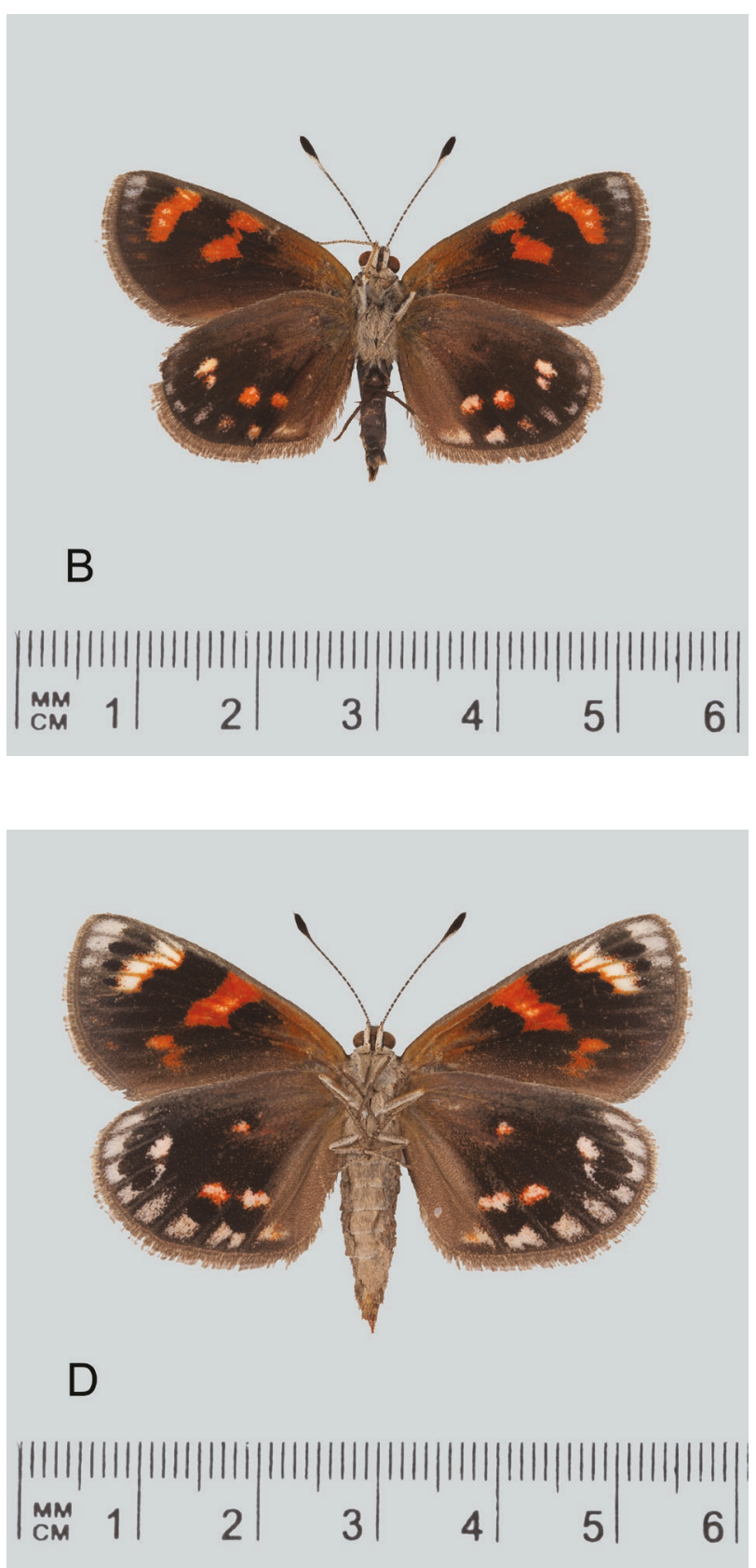


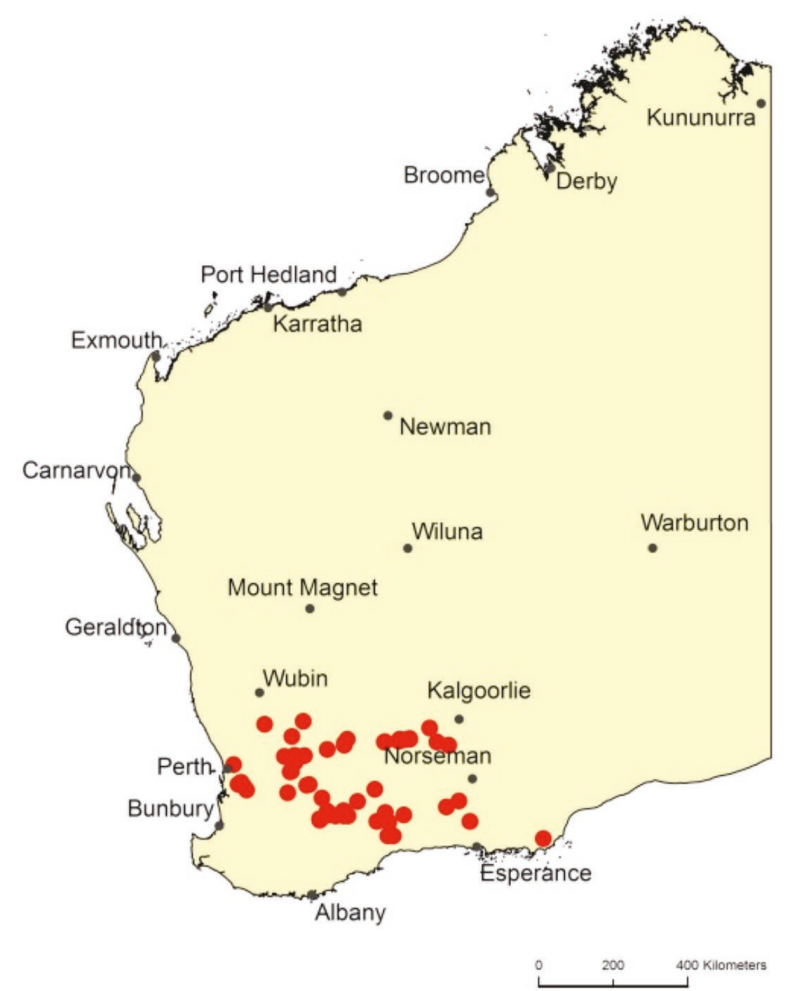

FIGURE 9 Map of Western Australia showing distribution of Synemon nupta.

Swan River, $31^{\circ} 51^{\prime} 00^{\prime \prime} \mathrm{S}, 116^{\circ} 00^{\prime} 00^{\prime \prime} \mathrm{E}$, date not recorded, L.J. Newman (WAM); Merredin, 31 29' $00^{\prime \prime} \mathrm{S}, 118^{\circ} 28^{\prime} 00^{\prime \prime}$ E, date not recorded, L.J. Newman (WAM); Lake Grace, $33^{\circ} 06^{\prime} 00^{\prime \prime} \mathrm{S}, 118^{\circ} 28^{\prime} 00^{\prime \prime} \mathrm{E}$, date not recorded, K. Carnaby; Cunderdin, $31^{\circ} 39^{\prime} 00^{\prime \prime} \mathrm{S}$, $117^{\circ} 13^{\prime} 48^{\prime \prime}$ E, 07 Oct 1913, R. Illidge; Cunderdin, 31 ${ }^{\circ}$ $39^{\prime} 00^{\prime \prime} \mathrm{S}, 117^{\circ} 13^{\prime} 48^{\prime \prime}$ E, 29 Oct 1913, R. Illidge (SAM);

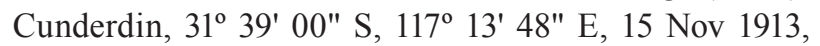
R. Illidge; 17 miles $\mathrm{W}$ of Ravensthorpe, $33^{\circ} 35^{\prime} 00^{\prime \prime} \mathrm{S}$, $119^{\circ} 44^{\prime} 00^{\prime \prime}$ E, 23 Nov 1958, I.F.B. Common; 9 mi. S by

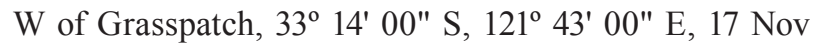
1969, Key and Upton; Near Emu Rock, E of Hyden, $32^{\circ}$ 27' 00" S, $119^{\circ} 25^{\prime} 00^{\prime \prime}$ E, 08 Nov 1979, T.F. Houston (WAM); Gabbin, 30 48' 00" S, $117^{\circ} 41^{\prime}$ 00" E, 22 Oct 1981, R.P. McMillan (WAM); Chandler Rd, Gleneagles State Forest, 32 $2^{\circ} 17^{\prime} 00^{\prime \prime}$ S, $116^{\circ} 11^{\prime} 00^{\prime \prime}$ E, 15 Dec 1984, R.W. Hay; $90 \mathrm{~km} \mathrm{E}$ of Southern Cross, 31 14' 00" S, $120^{\circ} 16^{\prime} 00^{\prime \prime}$ E, 27 Oct 1987, R.W. Hay; Yellowdine, $31^{\circ} 18^{\prime} 00^{\prime \prime} \mathrm{S}, 119^{\circ} 39^{\prime} 00^{\prime \prime}$ E, 27 Oct 1987, R.W. Hay; Quairading Bushland, 32 01' 00" S, $117^{\circ} 24^{\prime} 00^{\prime \prime} \mathrm{E}$, 03 Nov 1989, H. Bollam; 66 km E of Southern Cross, $31^{\circ} 14^{\prime} 00^{\prime \prime} \mathrm{S}, 120^{\circ} 01^{\prime} 00^{\prime \prime}$ E, 18 Oct 1991, R.W. Hay; $2 \mathrm{mi}$. SW of Quairading, $32^{\circ} 01^{\prime} 00^{\prime \prime} \mathrm{S}, 117^{\circ} 24^{\prime} 00^{\prime \prime} \mathrm{E}$, 02 Nov 1992, E.D. Edwards, E.S. Nielsen; $35 \mathrm{~km} \mathrm{E}$ of Yellowdine, 31 $11^{\circ} 00^{\prime \prime} \mathrm{S}, 120^{\circ} 00^{\prime} 00^{\prime \prime} \mathrm{E}, 03$ Nov 1992, E.D. Edwards, E.S. Nielsen; Cocanarup Reserve, $33^{\circ} 35^{\prime}$ 00" S, $119^{\circ} 52^{\prime} 00^{\prime \prime}$ E, 04 Nov 1994, A.A.E. Williams; Quairading, 32 01' 00" S, $117^{\circ} 24^{\prime} 00^{\prime \prime}$ E, 18 Nov 1994, A.A.E. Williams; Dragon Rocks Nature Reserve, $32^{\circ}$
45' 00" S, 11900'00" E, 24 Nov 1996, T.F. Houston (WAM); Peak Charles National Park, 32 $53^{\circ}$ 00" S, $121^{\circ}$ 09' 00" E, 02 Nov 1996, A.A.E. Williams.

\section{RECENT RECORDS}

Heathland Nature Reserve, $33^{\circ} 06^{\prime} 00^{\prime \prime} \mathrm{S}, 118^{\circ} 40^{\prime} 00^{\prime \prime}$ E, 01 Nov 2003, A.A.E. Williams; Wyalkatchem Nature Reserve, $31^{\circ} 10^{\prime} 14^{\prime \prime} \mathrm{S}, 117^{\circ} 24^{\prime} 49^{\prime \prime}$ E, 20 Oct 2007, A.A.E. Williams; Salmon Gums, $32^{\circ} 44^{\prime} 10^{\prime \prime} \mathrm{S}, 121^{\circ} 27^{\prime}$ $08^{\prime \prime}$ E, 02 Nov 2008, M. Peterson (MPC); Powerline Track, Albany Highway, 32 $28^{\prime}$ 03" S, $116^{\circ} 19^{\prime} 07^{\prime \prime}$ E, 23 Nov 2009, A.A.E. Williams; Tutanning Nature Reserve, $32^{\circ} 32^{\prime} 09^{\prime \prime} \mathrm{S}, 117^{\circ} 18^{\prime} 42^{\prime \prime}$ E, 24 Nov 2009, A.A.E. Williams; Quairading Bushland, $32^{\circ} 01^{\prime} 29^{\prime \prime} \mathrm{S}, 117^{\circ} 22^{\prime}$ 12" E, 18 Oct 2010, A.A.E. Williams; Westonia, 31 ${ }^{\circ} 19^{\prime}$ $35^{\prime \prime}$ S, $118^{\circ} 41^{\prime} 02^{\prime \prime}$ E, 19 Oct 2010, A.A.E. Williams; Carrabin, 31 22' 50" S, $118^{\circ} 40^{\prime} 38^{\prime \prime}$ E, 19 Oct 2010, A.A.E. Williams; Sandford Rock Nature Reserve, $31^{\circ} 14^{\prime}$ 08" S, 118 45' 16" E, 20 Oct 2010, T. Gamblin; 95 km E of Southern Cross, $31^{\circ} 12^{\prime} 47^{\prime \prime}$ S, $120^{\circ} 15^{\prime} 32^{\prime \prime}$ E, 21 Oct 2010, A.A.E. Williams; Yellowdine Nature Reserve, $31^{\circ}$ 17' 43" S, 119 39' 33" E, 21 Oct 2010, A.A.E. Williams; Queen Victoria Rock Nature Reserve, $31^{\circ} 18^{\prime} 03 " \mathrm{~S}, 120^{\circ}$ 55' 09" E, 21 Oct 2010, A.A.E. Williams; $43 \mathrm{~km} \mathrm{E}$ of

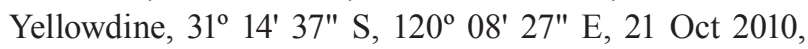
A.A.E. Williams; Elphin Nature Reserve, $30^{\circ} 52^{\prime} 14^{\prime \prime}$ S, $116^{\circ} 45^{\prime}$ 04" E, 26 Oct 2010, A.A.E. Williams; Kukerin Bushland, 33 10' 26" S, 118 04' 39" E, 01 Nov 2010, A.A.E. Williams; Kulin Bushland, $32^{\circ} 39^{\prime} 49^{\prime \prime}$ S, $118^{\circ}$ 08' 26" E, 01 Nov 2010, A.A.E. Williams; South Buniche Nature Reserve, $33^{\circ} 06^{\prime} 06^{\prime \prime} \mathrm{S}, 118^{\circ} 46^{\prime} 06^{\prime \prime}$ E, 02 Nov 2010, A.A.E. Williams; Old Newdegate Road, 33 ${ }^{\circ} 14^{\prime}$ 00" S, 19² 27' 59" E, 02 Nov 2010, A.A.E. Williams; Pallarup Nature Reserve, $33^{\circ} 15^{\prime} 12^{\prime \prime} \mathrm{S}, 19^{\circ} 45^{\prime} 28^{\prime \prime} \mathrm{E}$, 02 Nov 2010, A.A.E. Williams; Corrigin Bushland, $32^{\circ}$ $20^{\prime} 18^{\prime \prime} \mathrm{S}, 117^{\circ} 49^{\prime} 50^{\prime \prime}$ E, 02 Nov 2011, A.A.E. Williams; Charles Gardner Nature Reserve, $31^{\circ} 46^{\prime} 57^{\prime \prime}$ S, $117^{\circ} 29^{\prime}$ 53" E, 02 Nov 2011, A.A.E. Williams; 23 km NE of Lake Grace, $32^{\circ} 58^{\prime} 15^{\prime \prime}$ S, $118^{\circ} 39^{\prime} 43^{\prime \prime}$ E, 20 Nov 2011, A.A.E. Williams; Tarin Rock Nature Reserve, $33^{\circ} 06^{\prime} 28^{\prime \prime}$ S, $118^{\circ}$ 12' 25" E, 21 Nov 2011, A.A.E. Williams; North Tarin Rock Nature Reserve, $32^{\circ} 58^{\prime} 53^{\prime \prime} \mathrm{S}, 118^{\circ} 16^{\prime} 02^{\prime \prime}$ E, 21 Nov 2011, A.A.E. Williams; Kathleen Nature Reserve, $33^{\circ} 00^{\prime} 56^{\prime \prime} \mathrm{S}, 119^{\circ} 40^{\prime} 27^{\prime \prime} \mathrm{E}, 22$ Nov 2011, A.A.E. Williams; Frank Hann National Park, $33^{\circ} 04^{\prime} 37^{\prime \prime}$ S, $120^{\circ}$ 07' 07" E, 22 Nov 2011, A.A.E. Williams; Sullivan Rock, Albany Highway, $32^{\circ} 22^{\prime} 36^{\prime \prime}$ S, $116^{\circ} 15^{\prime} 08^{\prime \prime}$ E, 02 Dec 2011, A.A.E. Williams; Blue Rock, ENE of Jarrahdale, $32^{\circ} 19^{\prime} 40^{\prime \prime} \mathrm{S}, 116^{\circ} 06^{\prime} 52^{\prime \prime} \mathrm{E}, 16$ Dec 2011, A.A.E. Williams; Diamonds Hill, Cape Arid National Park, $33^{\circ} 39^{\prime} 01^{\prime \prime}$ S, $123^{\circ} 29^{\prime} 48^{\prime \prime}$ E, 01 Nov 2012, C.G. Miller; Kunjin Bushland, 32 21' 06" S, $117^{\circ} 46^{\prime}$ 12" E, 07 Nov 2012, A.A.E. Williams; Burra Rock, $S$ of Coolgardie, $31^{\circ}$ 22' 54" S, 121 $12^{\circ}$ '08" E, 11 Oct 2012, A.A.E. Williams and M.R. Williams; Sullivan Rock, Albany Highway, $32^{\circ}$ $22^{\prime} 36^{\prime \prime}$ S, $116^{\circ} 15^{\prime} 01^{\prime \prime}$ E, 01 Jan 2013, A.A.E. Williams; 1 km SE of Caenyie Rock, 30 57' 36" S, 120 44' 44" E, 12 Oct 2015, A.A.E. Williams. 


\section{Synemon sophia White 1841 (Flame Sun-moth)}

Figure 10

\section{BRIEF DESCRIPTION}

Synemon sophia is a distinctive, medium sized sunmoth with very rounded wings. In both sexes, the upper side of the forewing has a mix of black, whitish and grey markings, which in fresh specimens give the wing a grizzled appearance. The upper side of the hind wing is dull black, with large dark orange spots and markings. The bright orange hind wing markings may fade to
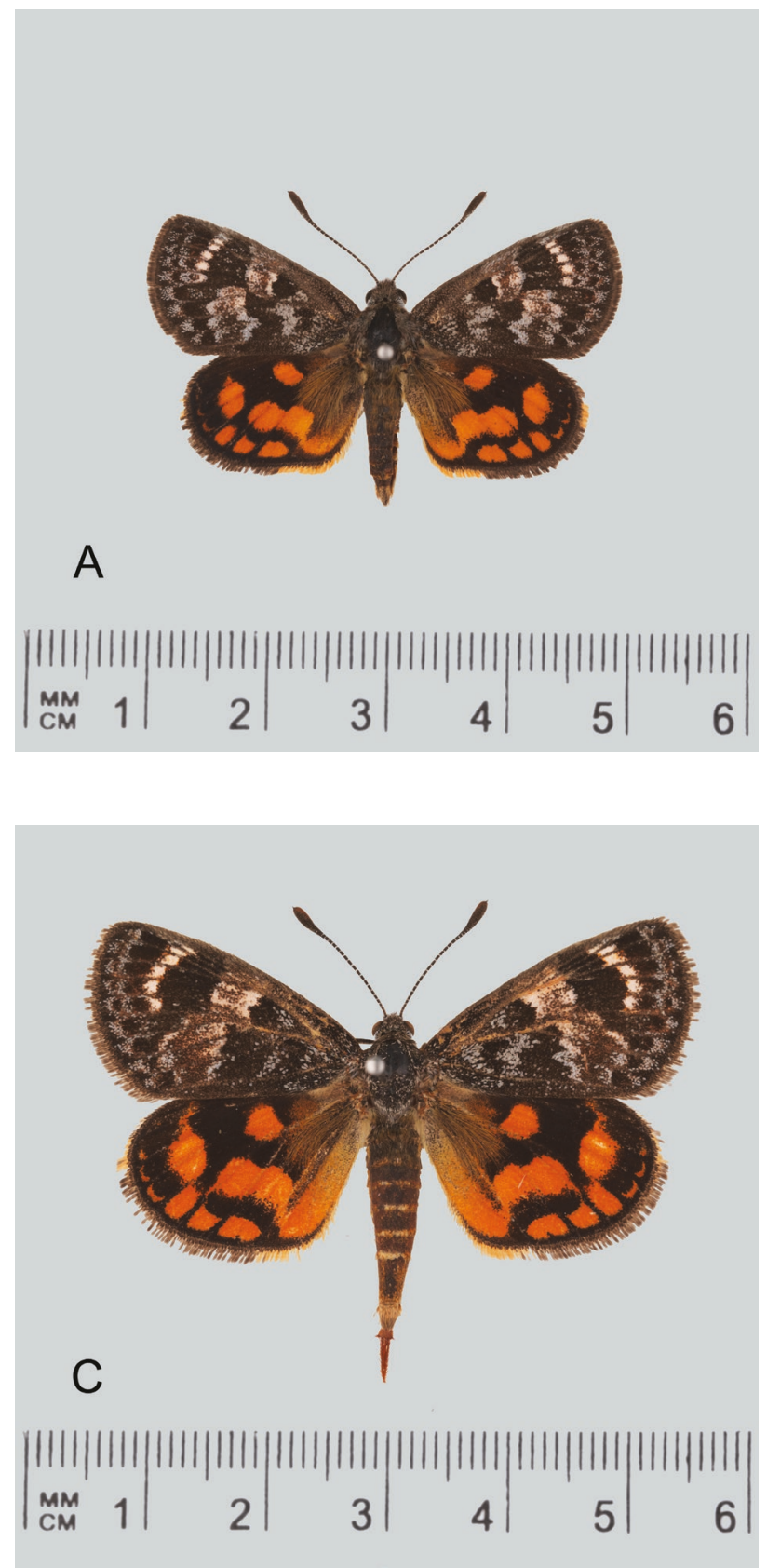

orange-yellow in specimens that have been on the wing for some time. The underside ground colour is black, with extensive orange bands and markings. In both sexes the large orange apical subterminal spot on the hind wing is overlain with smaller white markings. In females the broad central forewing band extends across the underside of the wing.

\section{DISTRIBUTION}

The earliest historical records for $S$. sophia are from King George Sound, Albany, and Wilson Inlet, near Denmark, but the species is almost certainly extinct
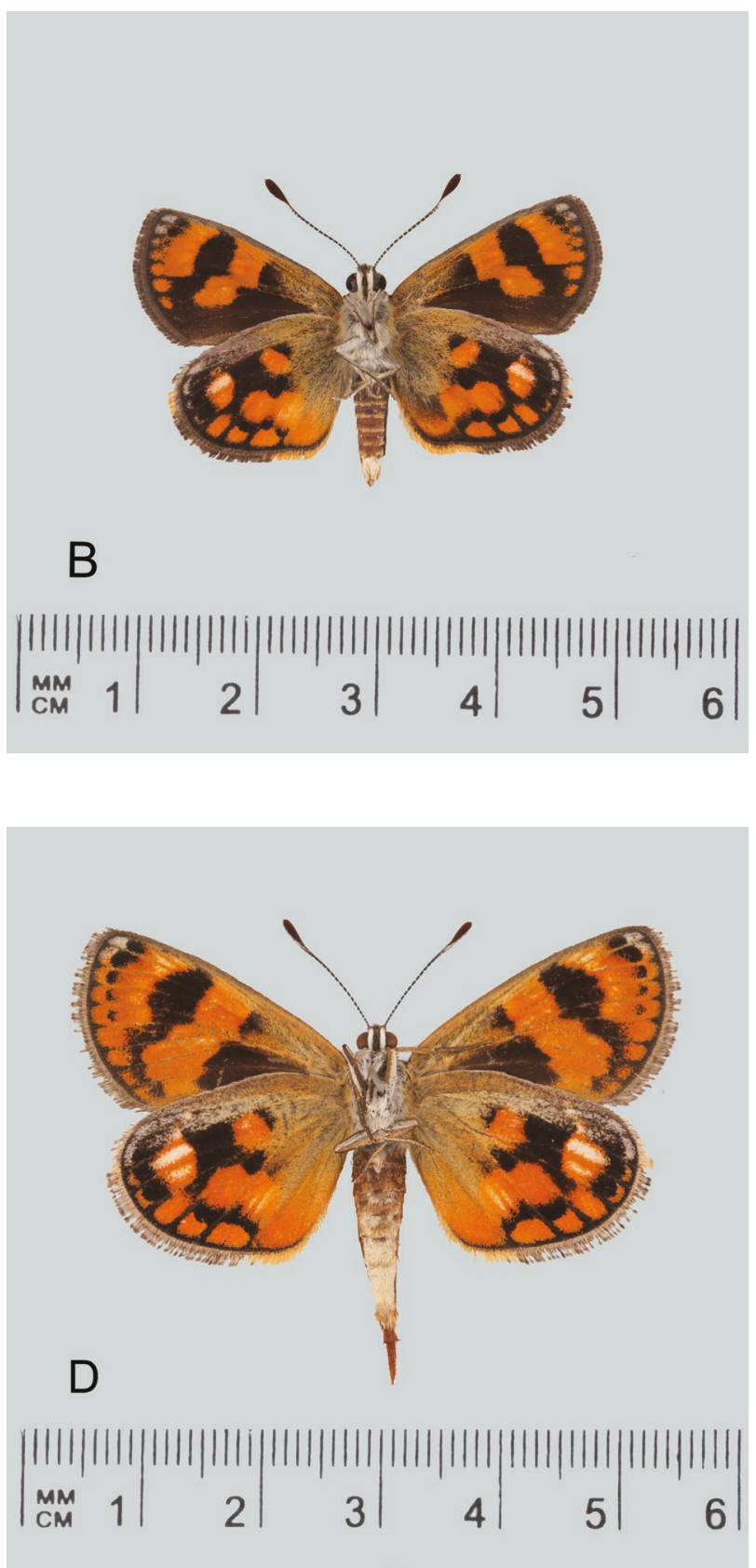

FIGURE 10 Synemon sophia. A, ô Dorsal; B, ô Ventral (C0863) Western Australia, Crystal Springs (WAM); C, ㅇ Dorsal; D, q Ventral (C1192) Western Australia, Crystal Springs (WAM). (Photos: Brian Hanich, Western Australian Museum.) 


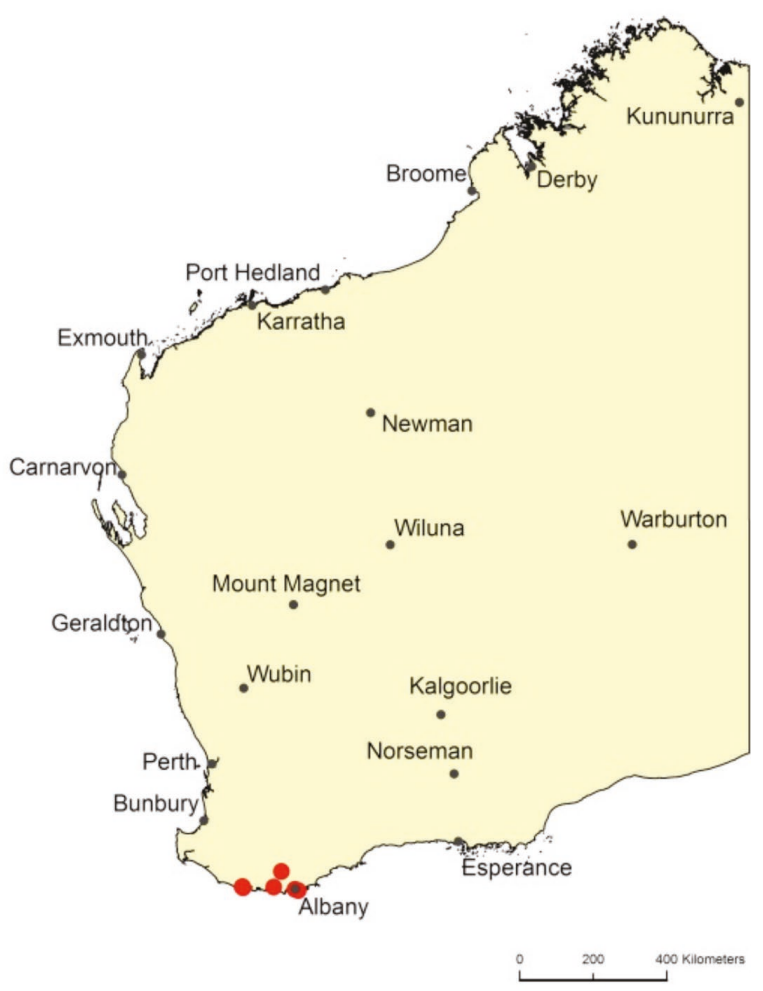

FIGURE $11 \quad$ Map of Western Australia showing distribution of Synemon sophia.

at these localities. In November 1996, E.D. Edwards collected two females at Hooper Road, Albany, both of which had been on the wing for some time and had orange-yellow hind wing markings. The species has not been recorded again at the Hooper Road site, which has been degraded by off-road vehicle use. In December 1970, S. sophia was recorded by G.A. Holloway and H. Hughes at Crystal Springs, near Walpole. All collections since 1996 have come from this location. Despite there being suitable looking habitat elsewhere along the south-west coast, this remains the only known extant population for S. sophia (Figure 11).

\section{LARVAL FOOD PLANT}

The larval food plant is unknown.

\section{HABITAT}

At Crystal Springs the main habitat is a winter-wet, peaty swamp with tall mixed sedges. The sun-moths occur in both the swampland and on adjacent higher ground near exposed granite sheets, where the habitat is very open eucalypt woodland over shrubs and sedges.

\section{BEHAVIOUR AND FLIGHT PERIOD}

Synemon sophia is active in sunny periods between 10:00 and 15:00 WST. The sun-moths invariably settle whenever the sun is shaded by cloud. Males do not establish clearly defined territories, but course over extensive areas of habitat in search of unmated females. The flight period is from early November to early December. Males are more frequently seen than females.

\section{CONSERVATION STATUS}

Data deficient - possibly endangered. Synemon sophia is now known from only one extant population near Walpole. Two specimens were collected at Hooper Road near Albany in 1996, but the species has not been recorded there again. Synemon sophia is thought to be extinct at its historical localities at King George Sound, Albany, and at Wilson Inlet, near Denmark. Insufficient surveys have been conducted to accurately determine its conservation status. Urban development in potentially suitable habitat along the south and south-west coast must be regarded as a likely threatening process. There are five historical and six recent records.

\section{HISTORICAL RECORDS}

Albany, King George Sound, 35 03' 00" S, $117^{\circ} 58^{\prime}$ 00" E, 16 Dec 1840, G. Grey (BMNH); Albany, King George Sound, 35 01' 00" S, $117^{\circ} 53^{\prime} 00^{\prime \prime}$ E, date not recorded, collector unknown (MM); Wilson Inlet, Denmark, $34^{\circ}$ 58' 00" S, $117^{\circ} 22^{\prime}$ 00" E, 11 Nov 1911, G.M. Goldfinch Collection (AM); Crystal Springs, W of Walpole, 34 ${ }^{\circ} 59^{\prime}$ 00" S, $116^{\circ} 37^{\prime}$ 00" E, 14 Dec 1970, G.A. Holloway and H. Hughes (AM); Hooper Road, Albany, 34 34' 48" S, $117^{\circ} 33^{\prime} 00^{\prime \prime}$ E, 26 Nov 1996, E.D. Edwards.

\section{RECENT RECORDS}

Walpole, Crystal Springs, $34^{\circ} 57^{\prime} 36^{\prime \prime} \mathrm{S}, 116^{\circ} 36^{\prime} 00^{\prime \prime}$ E, 02-04 Nov 2007, D. Hilton (AKC); Walpole, Crystal Springs, $34^{\circ} 57^{\prime} 35^{\prime \prime}$ S, $116^{\circ} 36^{\prime} 02^{\prime \prime}$ E, 03 Dec 2009, T. Gamblin; Walpole, Crystal Springs, $34^{\circ} 57^{\prime} 35^{\prime \prime} \mathrm{S}, 116^{\circ}$ 35' 59" E, 16 Nov 2010, T. Gamblin; Walpole, Crystal Springs, $34^{\circ} 57^{\prime} 35^{\prime \prime}$ S, $116^{\circ} 35^{\prime}$ 59" E, 17 Nov 2010, A.A.E. Williams; Walpole, Crystal Springs, $34^{\circ}$ 57' $^{\prime}$ $22^{\prime \prime}$ S, $116^{\circ} 35^{\prime} 18^{\prime \prime}$ E, 18 Nov 2010, A.A.E. Williams; Walpole, Crystal Springs, $34^{\circ} 57^{\prime} 35^{\prime \prime}$ S, $116^{\circ} 35^{\prime} 59^{\prime \prime}$ E, 19 Nov 2010, T. Gamblin.

\section{Synemon sp. 'Bob Hay' (Darkling Sun-moth)}

Figure 12

\section{BRIEF DESCRIPTION}

Synemon sp. 'Bob Hay' is unusual, in that it lacks the brightly coloured hind wings characteristic of many south-western Australian sun-moths. The upper surface of the forewing is patterned with variable shades of grey and lined with diffuse blackish markings. Some individuals, particularly females, have distinct white median and subapical markings near the leading edge of the forewing. The upper side of the hind wing is greyish-black, with a slightly iridescent sheen in oblique light. The underside is greyish-black, the forewing with whitish median and subapical markings near the leading 
edge of the forewing, the hindwing variably patterned with white spots and markings. In males, the area along the inner leading edge of the forewing is slightly iridescent yellow-brown.

\section{DISTRIBUTION}

Synemon sp. 'Bob Hay' is a Western Australian endemic. The first specimen was collected at Dedari in 1958. Subsequent specimens were recorded from three locations in the southern Wheatbelt: Dragon Rocks Nature Reserve, Tarin Rock Nature Reserve, and Dongolocking Nature Reserve (ANIC Castniidae database). It is now known to occur from Kalbarri
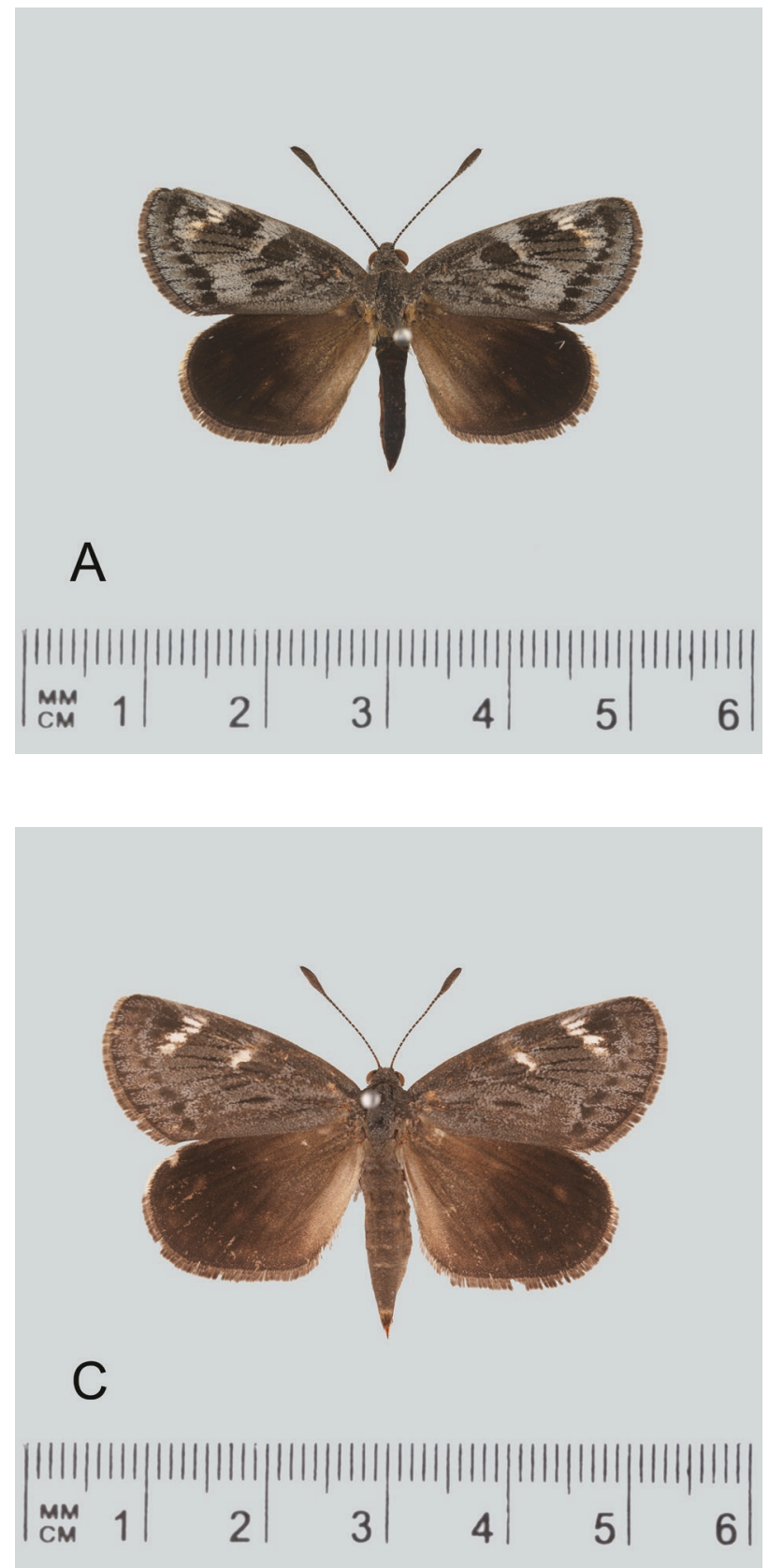

National Park in the north, southwards through the Wheatbelt to Tarin Rock Nature Reserve and Pallarup Nature Reserve, and inland to Caenyie Rock near Coolgardie and near McDermid Rock on the HydenNorseman Road (Figure 13).

\section{LARVAL FOOD PLANT}

The small semaphore sedge Mesomelaena preissii Nees is a confirmed larval food plant. The sunmoth's behaviour in and around Tussocky Cord-rush Ecdeiocolea monostachya F. Muell. suggests that this too may be a larval food plant.
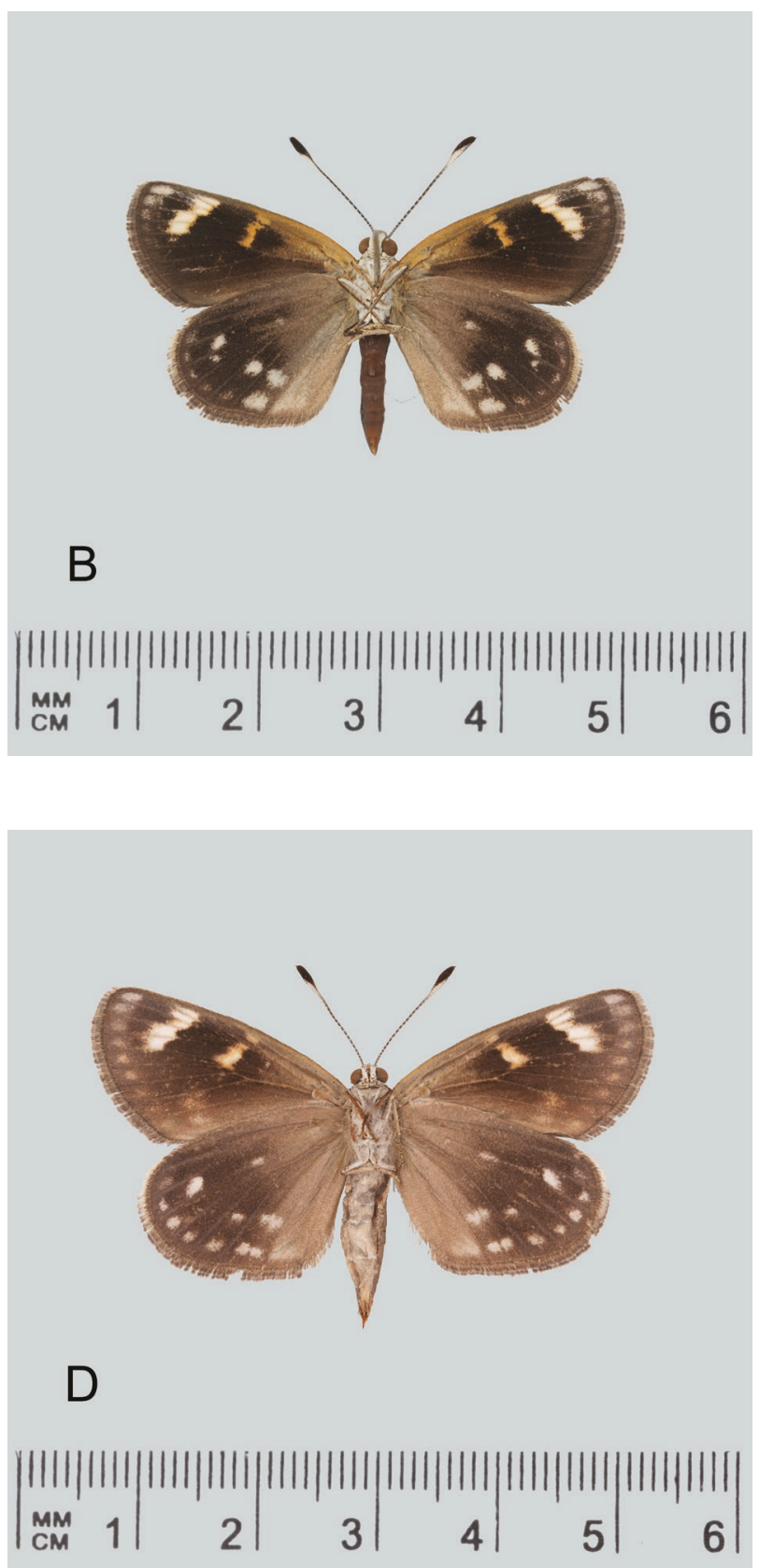

FIGURE 12 Synemon sp. 'Bob Hay'. A, ô Dorsal; B, ổ Ventral (C2983) Western Australia, Wyalkatchem (WAM); C, $q$ Dorsal; D, o Ventral (C1335) Western Australia, Kulin-Holt Rock Road (WAM). (Photos: Brian Hanich, Western Australian Museum.) 


\section{HABITAT}

This sun-moth is found in heath, shrubland and sedgeland, often in association with Tamma (Allocasuarina campestris). In the more northerly parts of its range $S$. sp. 'Bob Hay' is frequently found where E. monostachya and small semaphore sedges Mesomelaena species occur together.

\section{BEHAVIOUR AND FLIGHT PERIOD}

This summer flying sun-moth is active in sunny conditions from 09:30 to 16:30 WST. Males fly over areas of open low heath or sedgeland in search of unmated females. Although the sun-moths are sombre grey in colour, they look dark and can easily be seen in flight. When cloud cover appears the sun-moths seek shelter. They have a peculiar habit of settling on the underside of a low horizontal branch of a shrub, often close to the ground. In this position they are very difficult to detect. Their flight period is from mid February to March. Populations in southern localities emerge earlier than those in the north. At Quairading Nature Reserve, females have been observed and photographed ovipositing at the bases of the small semaphore sedge, M. preissi, which grows on white sandy-clay soils in Tamma (Allocasuarina campestris) shrubland (Magnus Peterson, personal observation 2015).

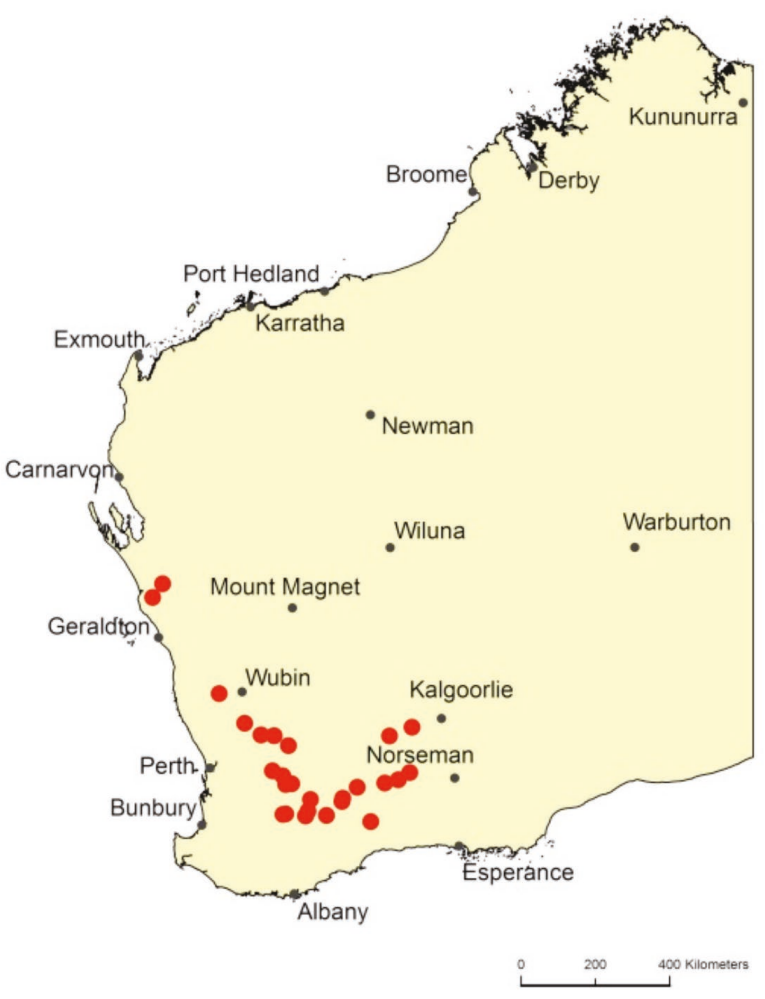

FIGURE 13 Map of Western Australia showing distribution of Synemon sp. 'Bob Hay'.

\section{CONSERVATION STATUS}

Not threatened. This species is widespread, locally common, and well represented in the conservation estate. There are five historical and 26 recent records.

\section{HISTORICAL RECORDS}

Dedari, location not recorded, January 1958, A.M. Douglas, R.P. McMillan (WAM); Dongolocking Nature Reserve, 330 05' 00" S, $117^{\circ} 37^{\prime} 00^{\prime \prime}$ E, 20 Feb 1996, T.F. Houston and C.K. Boase (WAM); $50 \mathrm{~km} \mathrm{~W}$ of Dedari, $31^{\circ} 10^{\prime} 28^{\prime \prime} \mathrm{S}, 120^{\circ} 11^{\prime} 56^{\prime \prime}$ E, 02 Feb 1997, P. Hutchinson (PHC); Tarin Rock, 330 07' 00" S, $118^{\circ} 10^{\prime} 00^{\prime \prime} \mathrm{E}, 17 \mathrm{Feb}$ 1997, E.S. Nielsen; Dragon Rocks, $32^{\circ} 46^{\prime} 00^{\prime \prime}$ S, $119^{\circ} 03^{\prime}$ 00" E, 18 Feb 1997, E.S. Nielsen.

\section{RECENT RECORDS}

$18 \mathrm{~km} \mathrm{~W}$ of Corrigin, $32^{\circ} 21^{\prime} 19^{\prime \prime} \mathrm{S}, 117^{\circ} 41^{\prime} 21^{\prime \prime} \mathrm{E}, 10$ Feb 2008, M. Peterson; $25 \mathrm{~km} \mathrm{SE}$ of Quairading, $32^{\circ}$ 08' 37" S, $117^{\circ} 36^{\prime} 57^{\prime \prime}$ E, 15 Feb 2010, A.A.E. Williams; Corrigin Bushland, $32^{\circ} 20^{\prime} 21^{\prime \prime} \mathrm{S}, 117^{\circ} 49^{\prime} 52^{\prime \prime}$ E, 15 Feb 2010, A.A.E. Williams; North Tarin Rock Nature Reserve, 330 00' 12" S, $118^{\circ} 13^{\prime} 39^{\prime \prime}$ E, 15 Feb 2010, A.A.E. Williams; Hopkins Nature Reserve, $32^{\circ} 43^{\prime}$ 11" S, $118^{\circ} 17^{\prime} 16^{\prime \prime}$ E, 16 Feb 2010, A.A.E. Williams; Heathland Nature Reserve, $33^{\circ} 06^{\prime} 13^{\prime \prime}$ S, $118^{\circ} 40^{\prime} 20^{\prime \prime}$ E, 16 Feb 2010, A.A.E. Williams; Tarin Rock Nature Reserve, $33^{\circ} 07^{\prime} 11^{\prime \prime} \mathrm{S}, 118^{\circ} 10^{\prime} 10^{\prime \prime} \mathrm{E}, 16$ Feb 2010, A.A.E. Williams; Dongolocking Nature Reserve, $33^{\circ}$ 04' 10" S, 117 41' 19" E, 17 Feb 2010, A.A.E. Williams; Elphin Nature Reserve, 30 51' 43" S, $116^{\circ} 41^{\prime} 32^{\prime \prime}$ E, 20 Feb 2010, A.A.E. Williams; Amery Nature Reserve, $31^{\circ}$ $08^{\prime} 52^{\prime \prime}$ S, $117^{\circ} 05^{\prime} 41^{\prime \prime}$ E, 20 Feb 2010, A.A.E. Williams; Wyalkatchem Nature Reserve, 31 $11^{\circ} 14^{\prime \prime}$ S, $117^{\circ} 24^{\prime} 16^{\prime \prime}$ E, 20 Feb 2010, A.A.E. Williams; Durocoppin Nature Reserve, 31 ${ }^{\circ} 24^{\prime} 29^{\prime \prime}$ S, $117^{\circ} 45^{\prime} 07^{\prime \prime}$ E, 20 Feb 2010, A.A.E. Williams; Nature Reserve at Gunyidi, $30^{\circ} 08^{\prime}$ 46" S, 116 04' 39" E, 01 Mar 2010, A.A.E. Williams; Kulin - Holt Rock Road, 32 $41^{\prime} 21^{\prime \prime}$ S, $119^{\circ} 04^{\prime} 01^{\prime \prime}$ E, 15 Feb 2011, A.A.E. Williams; Pallarup Nature Reserve, $33^{\circ}$ $15^{\prime} 22^{\prime \prime}$ S, 119 44' 46" E, 15 Feb 2011, A.A.E. Williams; $100 \mathrm{~km} \mathrm{~N}$ of Northampton, $27^{\circ} 28^{\prime} 15^{\prime \prime} \mathrm{S}, 114^{\circ} 42^{\prime} 24^{\prime \prime}$ E, 24 Mar 2011, A.A.E. Williams; Kalbarri National Park, $27^{\circ} 48^{\prime} 24^{\prime \prime}$ S, 114 $28^{\circ} 03^{\prime \prime}$ E, 24 Mar 2011, A.A.E. Williams and M.R. Williams; Wyalkatchem Nature Reserve, $31^{\circ} 10^{\prime} 13^{\prime \prime} \mathrm{S}, 117^{\circ} 24^{\prime} 18^{\prime \prime}$ E, 15 Feb 2013, A.A.E. Williams; Wyalkatchem Nature Reserve, $31^{\circ}$ 10' 13" S, 117 24' 18" E, 28 Feb 2013, A.A.E. Williams; Quairading Nature Reserve, $32^{\circ} 01^{\prime} 23^{\prime \prime} \mathrm{S}, 117^{\circ} 21^{\prime} 59^{\prime \prime} \mathrm{E}$, $17 \mathrm{Feb} 2015$, M. Peterson (MPC); $52 \mathrm{~km} \mathrm{E}$ of Hyden, $32^{\circ}$ $25^{\prime} 20^{\prime \prime} \mathrm{S}, 19^{\circ} 24^{\prime} 59^{\prime \prime} \mathrm{E}, 11 \mathrm{Feb} 2016$, A.A.E. Williams; $115 \mathrm{~km} \mathrm{E}$ of Hyden, 32 $19^{\prime} 07^{\prime \prime} \mathrm{S}, 120^{\circ} 04^{\prime} 57^{\prime \prime} \mathrm{E}, 11$ Feb 2016, A.A.E. Williams; $147 \mathrm{~km}$ E of Hyden, 32 ${ }^{\circ}$ 14' 19" S, $120^{\circ} 24^{\prime} 30^{\prime \prime}$ E, 11 Feb 2016, A.A.E. Williams; 6 $\mathrm{km} \mathrm{SW}$ of McDermid Rock, 32 ${ }^{\circ} 03^{\prime} 54^{\prime \prime} \mathrm{S}, 120^{\circ} 41^{\prime} 31^{\prime \prime}$ E, 12 Feb 2016, A.A.E. Williams; $1 \mathrm{~km} \mathrm{SW}$ of Caenyie Rock, $30^{\circ} 57^{\prime} 37^{\prime \prime} \mathrm{S}, 120^{\circ} 44^{\prime} 42^{\prime \prime}$ E, 14 Feb 2016, A.A.E. Williams; Amery Nature Reserve, $31^{\circ} 09^{\prime} 05^{\prime \prime} \mathrm{S}, 117^{\circ} 05^{\prime}$ 21" E, 27 Feb 2016, A.A.E. Williams. 


\section{Synemon sp. nr. discalis (Western orange-spotted Sun-moth)}

Figure 14

\section{BRIEF DESCRIPTION}

Synemon sp. nr. discalis has a wingspan of approximately $30-35 \mathrm{~mm}$ in males and $40 \mathrm{~mm}$ in females. The wing pattern in both sexes is similar. The upper side of the forewing is dark grey, suffused with blackish markings. In most individuals there is a very small white median spot and some suffused subapical whitish spots near the leading edge of the forewing.
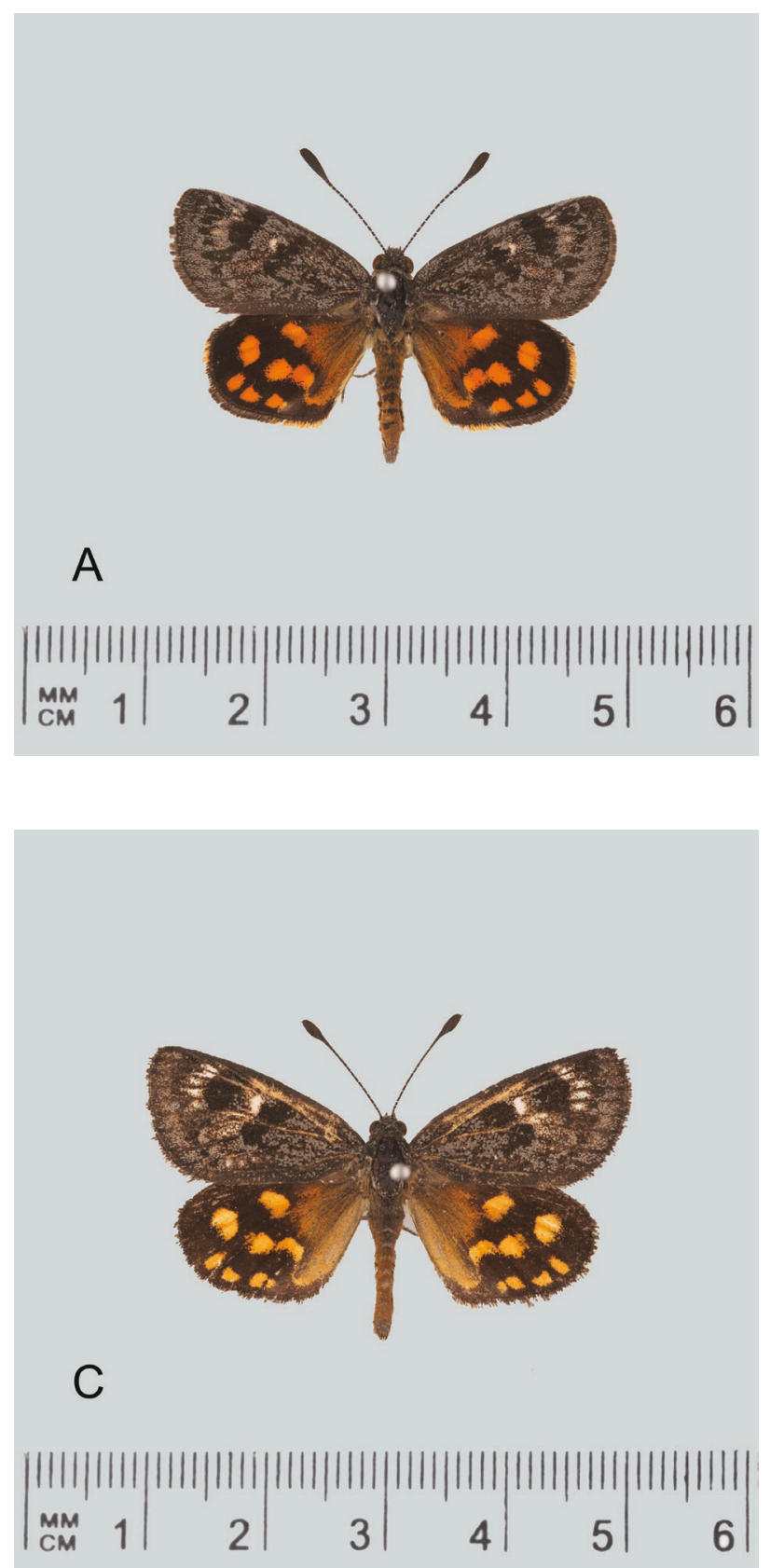

Females are similar to males, but the white median and subapical spots on the upper side of the forewing are more pronounced. The upper side of the hind wing is brownish-black, with a distinct orange discal spot. There are three prominent orange postmedian spots across the centre of the wing, the innermost of which often 'tails' into the inner margin next to the abdomen. This inner margin is yellowish-orange and may appear slightly iridescent in oblique light. Three or four subterminal orange spots are located close to the trailing edge of the hind wing. The underside of the forewing has two prominent pale orange-brown bands, the outer one overlain with whitish spots. There is also a line of small
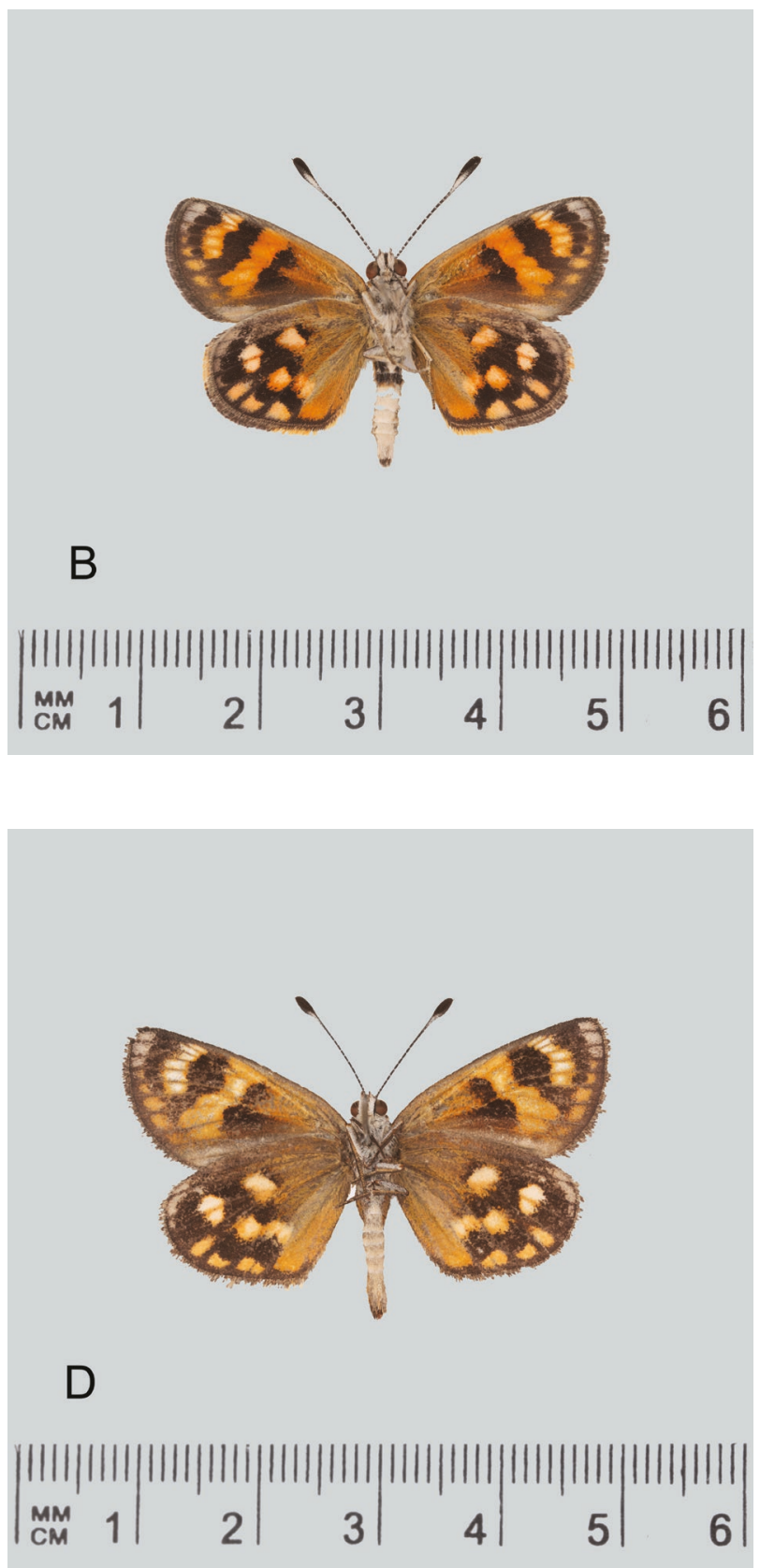

FIGURE 14 Synemon sp. nr. discalis. A, đ̃ Dorsal; B, đ Ventral (C3068) Western Australia, Jimberlana Hill (WAM); C, o Dorsal; D, o Ventral (C3062) Western Australia, Jimberlana Hill (WAM). (Photos: Brian Hanich, Western Australian Museum.) 


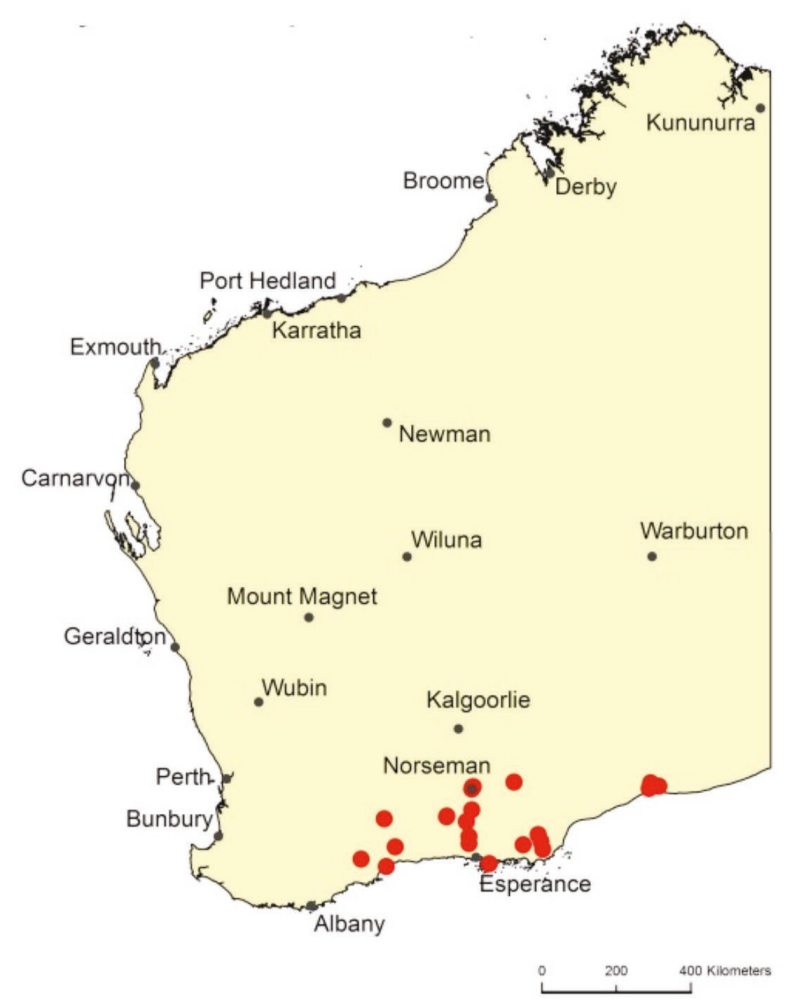

FIGURE 15 Map of Western Australia showing distribution of Synemon sp. nr. discalis.

paler apical-terminal spots close to the outer edge of the forewing. The underside of the hind wing has markings similar to those on the upper surface, but paler.

\section{DISTRIBUTION}

Synemon sp. nr. discalis is a Western Australian endemic, where it has a south to south-eastern distribution. The (ANIC) Castniidae database lists several localities, including Salmon Gums, Norseman, Pine Hill, $(18 \mathrm{~km}$ north of Mount Ragged), and Cocklebiddy. The species has been recorded as far west as Peak Charles National Park, at sites along the Norseman-Esperance Highway, at Jimberlana Hill, at Mount Ragged in Cape Arid National Park, and at Cocanarup Reserve near Ravensthorpe (Figure 15). Specimens from Fitzgerald River National Park and Esperance are provisionally placed here. A similar eastern Australian species, Synemon discalis Strand 1911, occurs in Victoria and South Australia (Douglas 2004; Grund 2012). The precise locality for the $S$. discalis holotype male is not stated in the original descrption, but inferred to be South Australia (Douglas 2004).

\section{LARVAL FOOD PLANT}

The larval food plant at the base of Jimberlana Hill near Norseman is Gahnia aff. aristata (F. Muell.) Benth. (Russell Barrett, personal communication).

\section{HABITAT}

Synemon sp. nr. discalis is usually found in open mallee and shrubland habitats growing on sandy clay soils. In Peak Charles National Park the habitat is often denser mallee shrubland.

\section{BEHAVIOUR AND FLIGHT PERIOD}

Males are seen more often than females. They are active in warm to hot, sunny conditions and are usually seen flying in open areas near their larval food plants. At Peak Charles National Park, males use vehicle tracks as flight-paths through the dense mallee shrubland. Synemon sp. nr. discalis flies in October and early November.

\section{CONSERVATION STATUS}

Not threatened. This species is restricted to south and south-eastern Western Australia. It is found in Cape Arid National Park, Peak Charles National Park and Cape Le Grand National Park, as well as Jimberlana Hill conservation area near Norseman. There are 16 historical and seven recent records.

\section{HISTORICAL RECORDS}

Norseman (general), 32 $12^{\prime} 00^{\prime \prime} \mathrm{S}, 121^{\circ} 47^{\prime} 00^{\prime \prime} \mathrm{E}, 26$ Oct 1958, I.F.B. Common; $35 \mathrm{mi}$. S of Norseman, $32^{\circ} 42^{\prime}$ 00" S, $121^{\circ} 47^{\prime} 00^{\prime \prime}$ E, 21 Oct 1966, L.E. Couchman, R. Couchman; Fraser Range, $32^{\circ} 02^{\prime} 00^{\prime \prime} \mathrm{S}, 122^{\circ} 48^{\prime} 00^{\prime \prime} \mathrm{E}$, 15 Oct 1967, J.C. Le Souef; Salmon Gums, 32 59' 00" S, $121^{\circ} 39^{\prime} 00^{\prime \prime}$ E, 17 Oct 1967, J.C. Le Souef; Eyre, 32 $08^{\prime} 00^{\prime \prime}$ S, $126^{\circ} 18^{\prime} 00^{\prime \prime}$ E, 19 Oct 1967, J.C. Le Souef; 4 miles NNE of Norseman, 32 09' 00" S, $121^{\circ} 48^{\prime} 00^{\prime \prime} \mathrm{E}$, 12 Oct 1968, Britton Upton Balderson; 9 mi. S by W of Cocklebiddy, 32 11' 00" S, $126^{\circ} 04^{\prime}$ 00" E, 03 Nov 1969, Key and Upton; Cocklebiddy, $32^{\circ} 05^{\prime} 00^{\prime \prime} \mathrm{S}, 126^{\circ} 10^{\prime} 00^{\prime \prime}$ E, 20 Oct 1977, A. Atkins; $10 \mathrm{~km} \mathrm{~S}$ of Cocklebiddy, $32^{\circ}$ 08' 00" S, 1260 06' 00" E, 20 Oct 1977, A. Atkins; Twin Bays, Fitzgerald River National Park, 34 04' 00" S, $119^{\circ}$ 43' 00" E, 27-28 Oct 1979, T.F. Houston (WAM); Pine Hill, $18 \mathrm{~km} \mathrm{~N}$ of Mt. Ragged, 33 $18^{\circ} 00^{\prime \prime} \mathrm{S}, 123^{\circ} 23^{\prime}$ 00" E, 13 Oct 1991, R.W. Hay; Cocanarup Reserve, 33 35' 49" S, $119^{\circ}$ 55' 42" E, 04 Nov 1994, M.R. Williams; Cape Arid National Park, Mt. Ragged, 33 $27^{\prime} 56^{\prime \prime}$ S, $123^{\circ} 27^{\prime} 08^{\prime \prime}$ E, 05 Nov 1994, M.R. Williams; Cape Le Grand National Park, 33 ${ }^{\circ} 59^{\prime}$ 57" S, $122^{\circ} 12^{\prime}$ 24" E, 07 Nov 1994, M.R. Williams; Peak Charles National Park, $32^{\circ} 52^{\prime} 00^{\prime \prime} \mathrm{S}, 121^{\circ} 10^{\prime} 24^{\prime \prime} \mathrm{E}, 19$ Oct 1996, P. Hutchinson (PHC); $20 \mathrm{~km} \mathrm{~N}$ of Lake King, 32 ${ }^{\circ} 55^{\prime} 05^{\prime \prime} \mathrm{S}, 119^{\circ} 39^{\prime}$ 46" E, 20 Oct 1996, P. Hutchinson (PHC).

\section{RECENT RECORDS}

Fitzgerald River National Park, $33^{\circ} 53^{\prime} 12^{\prime \prime} \mathrm{S}, 119^{\circ}$ 06' 21" E, 03 Nov 2000, M.R. Williams; Peak Charles

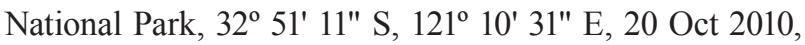
A.A.E. Williams; Esperance, $33^{\circ} 48^{\prime} 14^{\prime \prime}$ S, $121^{\circ} 51^{\prime} 51^{\prime \prime}$ E, 03 Nov 2010, A.A.E. Williams; Esperance-Norseman Highway, 33 $30^{\prime} 41^{\prime \prime}$ S, $121^{\circ} 42^{\prime} 55^{\prime \prime}$ E, 03 Nov 2010, A.A.E. Williams; $10 \mathrm{~km} \mathrm{~N}$ of Scaddan, 33 20' 29" S, $121^{\circ} 42^{\prime}$ 54" E, 03 Nov 2010, A.A.E. Williams; Diamonds Hill, Cape Arid National Park, $33^{\circ} 39^{\prime} 01^{\prime \prime}$ S, $123^{\circ} 29^{\prime} 48^{\prime \prime}$ E, 01 Nov 2012, C. Meyer, C.L. Miller and S. Brown; Jimberlana Hill, Norseman, 32 $08^{\prime} 2^{\prime} 9^{\prime \prime} \mathrm{S}, 121^{\circ} 49^{\prime} 01^{\prime \prime}$ E, 2-6 Oct 2013, A.A.E. Williams. 


\section{Synemon sp. 'Leeman' (Little Western Sun-moth)}

Figure 16

\section{BRIEF DESCRIPTION}

This is a small sun-moth. Males and females are of similar size, with wing-spans of 30-35 mm. In both sexes, the upper side of the forewing has a delicate pattern of grey and black markings, often with some fine whitish subapical and postmedian markings. The base colour on the upper side of the hind wing is blackishbrown, with a very small orange-yellow discal spot and
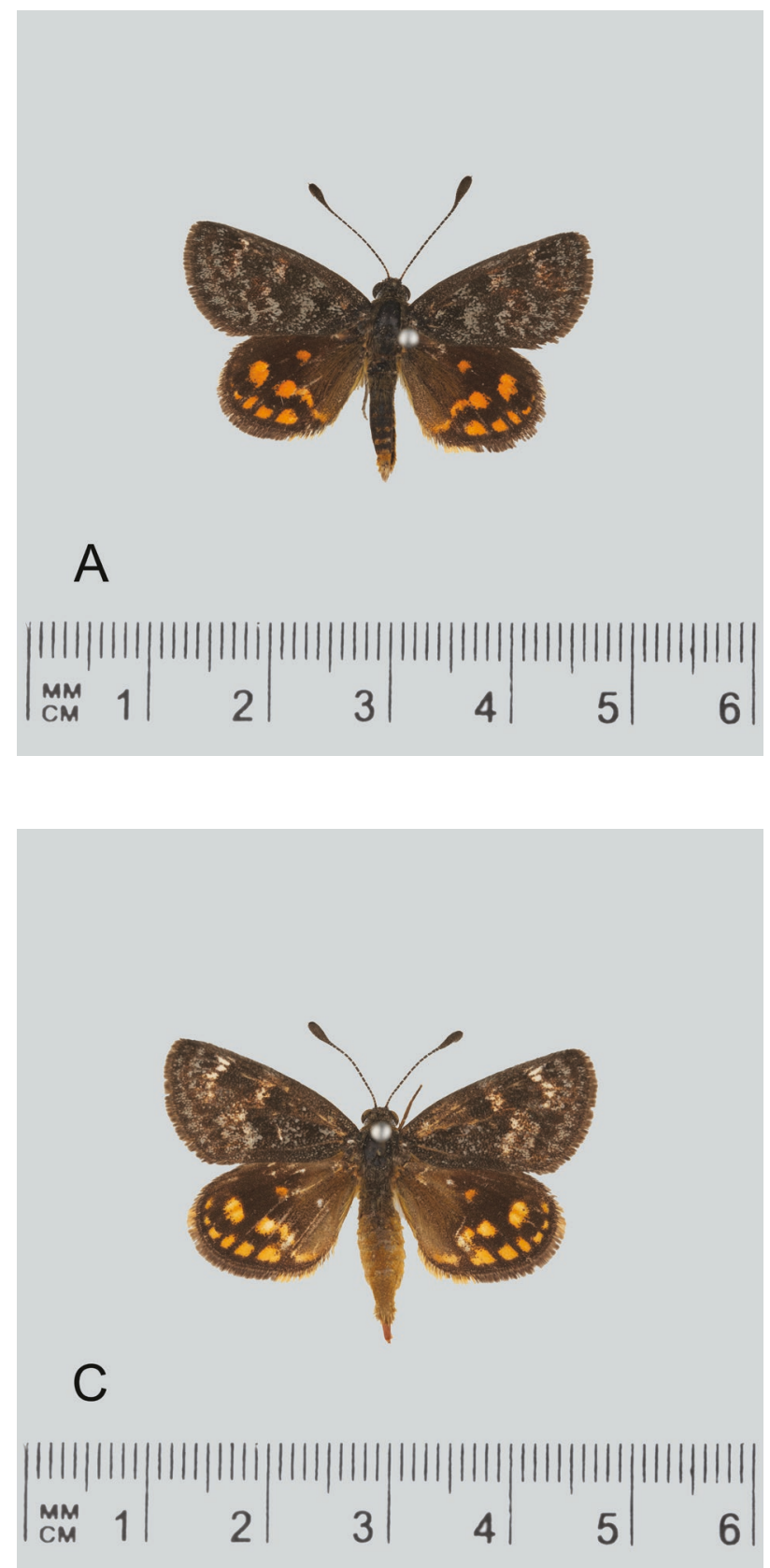

a band of three orange-yellow postmedian spots, which may be partially fused. The outer wing margin has a row of small orange-yellow subterminal spots. The underside of the forewing is blackish-brown, with two broad irregular orange-yellow bands. The outer edge of the wing has a row of small orange-yellow terminal spots. The markings on the underside of the hind wing are similar to those on the upper side.

\section{DISTRIBUTION}

This sun-moth is endemic to Western Australia. It has a restricted distribution along the west coast north of
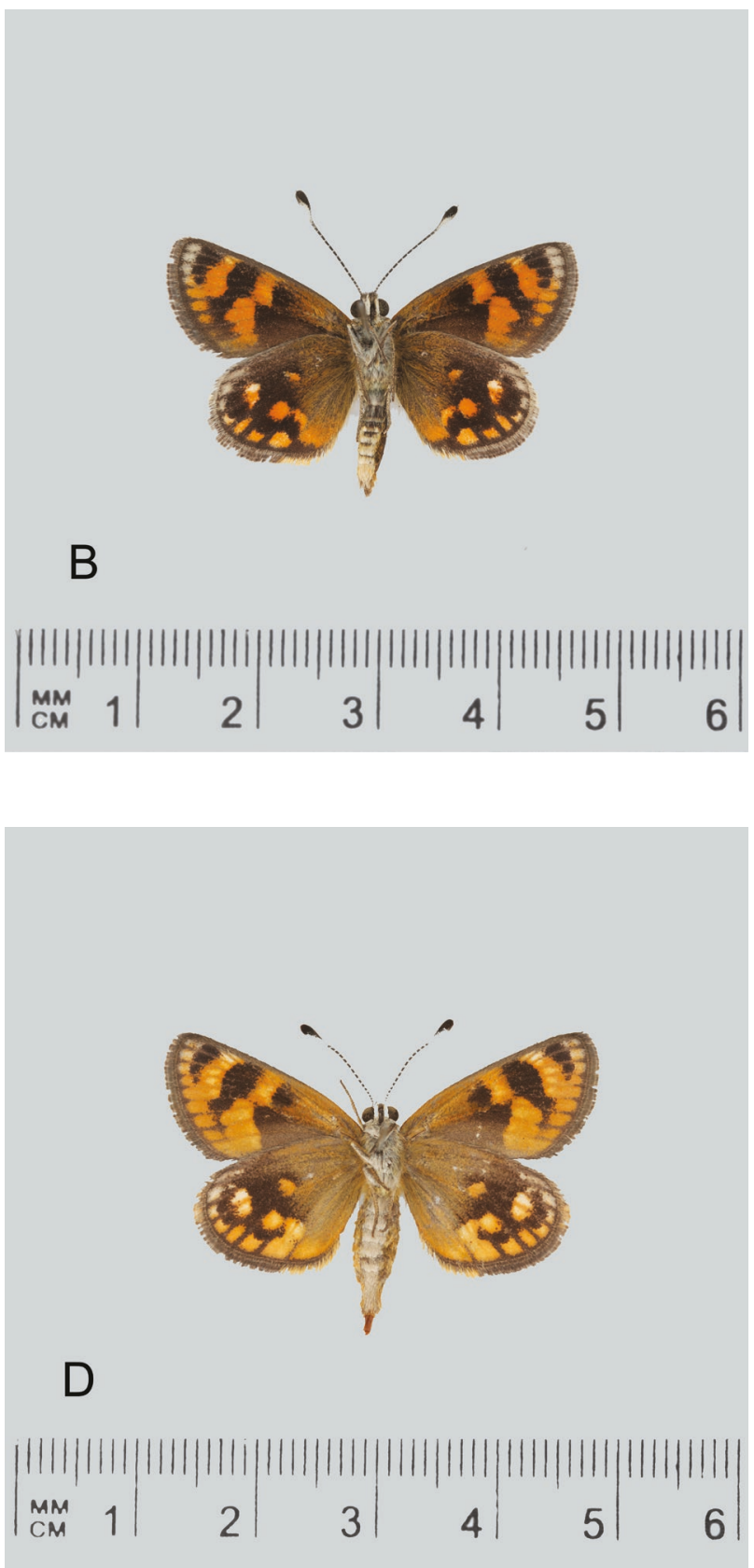

FIGURE 16 Synemon sp. 'Leeman'. A, ô Dorsal; B, ô Ventral (C0694) Western Australia, Green Head (WAM); C, o Dorsal; D, o Ventral (C0693) Western Australia, Green Head (WAM). (Photos: Brian Hanich, Western Australian Museum.) 


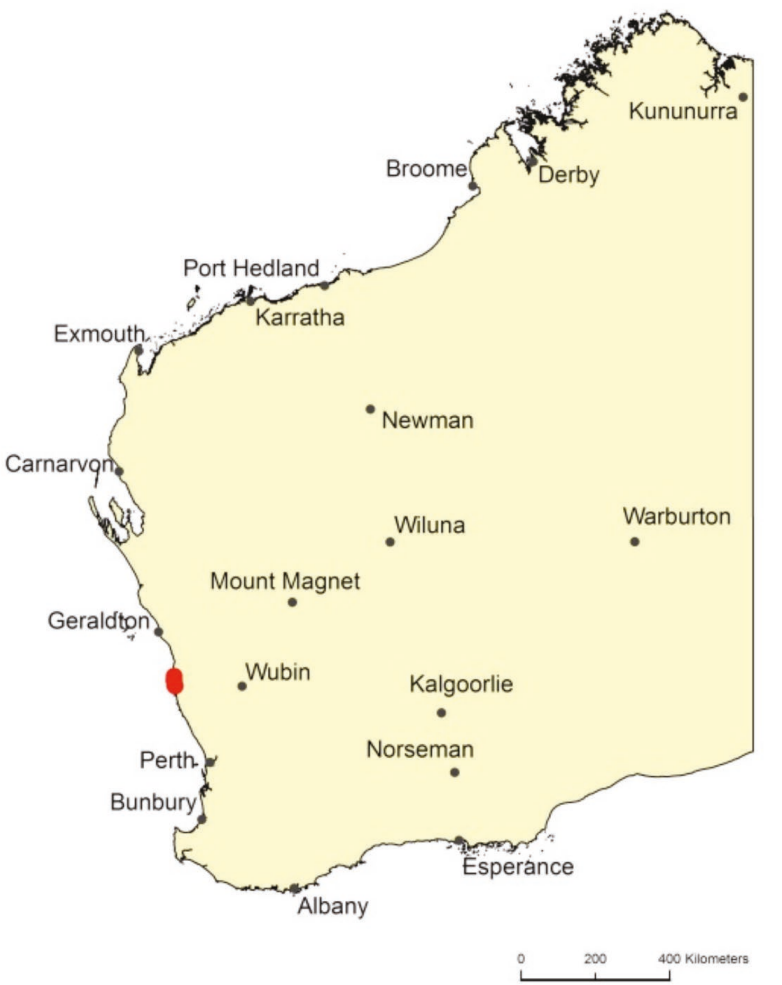

FIGURE 17 Map of Western Australia showing distribution of Synemon sp. 'Leeman'.

Perth, from Green Head to Coolimba, $10 \mathrm{~km}$ north of Leeman (Figure 17).

\section{LARVAL FOOD PLANT}

The larval food plant is undoubtedly Woolly Bog-rush Schoenus lanatus Labill. (Russell Barrett identification, personal communication, 2013), a sedge which grows abundantly in all the locations where the sun-moth has been found. In most instances it is the only sedge present, and females have been observed moving down inside the sedge clumps.

\section{HABITAT}

At Green Head and Leeman the habitat for $S$. sp. 'Leeman' is mixed Melaleuca and Acacia thicket, growing on near-coastal limestone pavement overlain with a thin layer of sandy topsoil. Near Green Head, the sun-moths are most often encountered along roads, where slashed roadside verges have allowed the continued growth of low shrubs and the small larval food plant sedges. Similarly, near Leeman, the sun-moths were active on a 100 metre wide mowed perimeter firebreak south of the town. At Coolimba Road, the species flies in sheltered swales between vegetated near-coastal sand dunes.

\section{BEHAVIOUR AND FLIGHT PERIOD}

Synemon sp. 'Leeman' is locally common. Adults are active in sunny conditions, from mid morning to mid afternoon. They fly close to the ground, settling periodically on low plants. Males do not exhibit territorial behavior, but fly randomly over areas where the small larval food plant sedge is abundant. Specimens have been collected in early and mid October.

\section{CONSERVATION STATUS}

Data deficient. Further surveys are required to document the full extent of this small sun-moth's distribution and the proportion of the population which exists in the conservation estate. There are four historical and four recent records.

\section{HISTORICAL RECORDS}

$2 \mathrm{~km} \mathrm{~S}$ of Leeman, 29 $58^{\prime} 00^{\prime \prime} \mathrm{S}, 114^{\circ} 59^{\prime} 00^{\prime \prime} \mathrm{E}, 14$ Oct 1988, R.W. Hay; $2 \mathrm{~km} \mathrm{~S}$ of Leeman, $29^{\circ} 58^{\prime} 00^{\prime \prime}$ S, $114^{\circ} 59^{\prime} 00^{\prime \prime}$ E, 25 Oct 1988, R.W. Hay; $2 \mathrm{~km} \mathrm{~S}$ of Leeman, $2^{\circ} 58^{\prime} 00^{\prime \prime} \mathrm{S}, 114^{\circ} 59^{\prime} 00^{\prime \prime} \mathrm{E}, 30$ Oct 1992, E.D. Edwards and E.S. Nielsen; $9 \mathrm{~km} \mathrm{~N}$ of Leeman, 29 $52^{\prime}$ 00" S, $114^{\circ} 59^{\prime}$ 00" E, 25 Oct 1996, M. Golding and M. Powell.

\section{RECENT RECORDS}

$5 \mathrm{~km} \mathrm{~S}$ of Green Head, $30^{\circ} 05^{\prime} 49^{\prime \prime} \mathrm{S}, 115^{\circ} 00^{\prime} 27^{\prime \prime} \mathrm{E}$, 08 Oct 2010, A.A.E. Williams; Near Green Head, $30^{\circ}$ 04' 39" S, $114^{\circ} 59^{\prime} 52^{\prime \prime}$ E, 08 Oct 2010, A.A.E. Williams; $500 \mathrm{~m} \mathrm{~S}$ of Leeman, $29^{\circ} 57^{\prime} 26^{\prime \prime} \mathrm{S}, 114^{\circ} 58^{\prime} 39^{\prime \prime} \mathrm{E}, 08$ Oct 2010, A.A.E. Williams; $10 \mathrm{~km} \mathrm{~N}$ of Leeman, 29 51' 31" S, $114^{\circ} 59^{\prime} 02^{\prime \prime}$ E, 15 Oct 2010, M.R. Williams and T. Gamblin.

\section{Synemon sp. 'Mount Ragged' (Hilltop Sun-moth)}

Figure 18

\section{BRIEF DESCRIPTION}

Synemon sp. 'Mount Ragged' is a distinctive medium sized sun-moth with angular forewings. In males, the upper side of the forewing is grey with a broad whitish postmedian band bordered in black. A group of whitish subapical spots form a parallel though less distinct band towards the outer tip of the wing. The upper side of the hind wing in the male is blackish, with a discrete orange-brown discal spot and a line of partially fused orange-brown postmedian spots, the innermost of which tails into the dorsum alongside the abdomen. Close to the trailing edge of the hind wing are two distinct white terminal spots enclosed within the black outer border. In males, the basal area on the underside of both wings is orange-brown. The ground colour on the remainder of the wings is dull black. The forewing has two broad orange-brown or orange-white bands and a row of fine white terminal spots. The underside of the male hind wing is patterned with orange-brown and white spots and markings. In females, the forewing shape and upper side pattern is similar to that of the male, though the 
termen is more rounded. The hind wing upper side is blackish with a large elongate orange-yellow discal spot and a line of large partially fused orange-yellow postmedian spots, the innermost of which tails into the dorsum alongside the abdomen. Close to the trailing edge of the hind wing are two distinct but very much smaller pale orange-yellow or whitish-yellow terminal spots enclosed within the black outer border; in males these spots are white. On the underside the basal area on both wings is orange-yellow. The outer portion on the underside of the female's forewing has a broad postmedian and subapical orange-yellow band, the latter with two elongate parallel white spots alongside the costa. A row of small white or yellow-white spots are located close to the termen. On the underside of the female's hindwing the orange-yellow basal area extends into the dorsum and joins the broad orangeyellow postmedian band. An irregular black median band extends part-way down across the wing between the orange-yellow basal area and the orange-yellow postmedian band. The outer edge of the hind wing from apex to tornus is broadly bordered in black. This border encloses a narrow line of very small white terminal spots and two larger white spots towards the tornus.
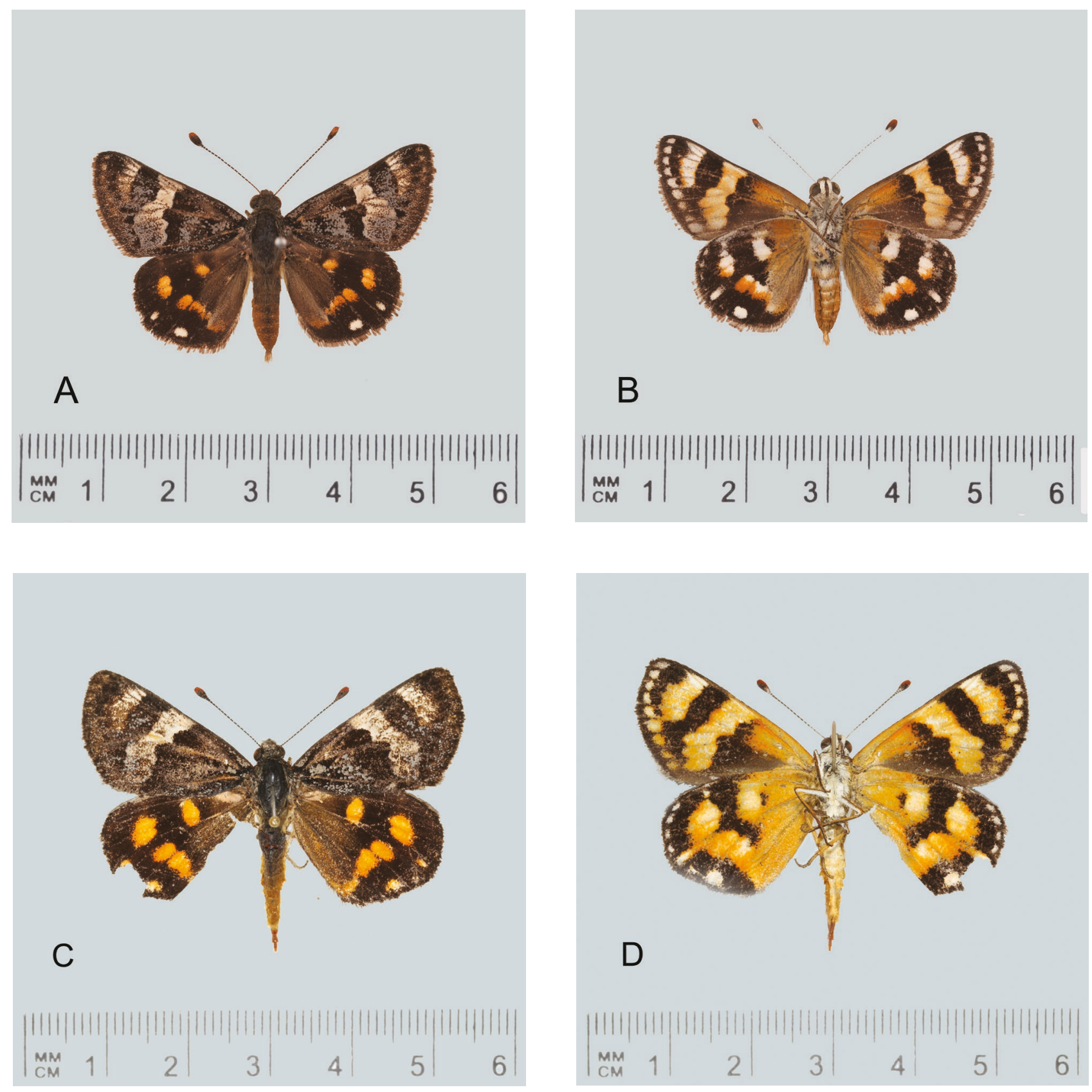

FIGURE 18 Synemon sp. 'Mount Ragged'. A, đ̃ Dorsal; B, ô Ventral (C0627) Western Australia, Stirling Range (WAM); C, o Dorsal; D, o Ventral (ANIC31015296) Western Australia, 26 km east of Ravensthorpe (ANIC). (Photos: A-B, Brian Hanich, Western Australian Museum; C-D, You Ning Su, CSIRO, Canberra.) 


\section{DISTRIBUTION}

This south coastal taxon is a Western Australian endemic. It is known from Stirling Range National Park in the west, east to Ravensthorpe, Mount Ragged in Cape Arid National Park, and the area round Israelite Bay (ANIC Castniidae database). More recently it has been located on West Mount Barren in Fitzgerald River National Park (Figure 19).

\section{LARVAL FOOD PLANT}

The larval food plant is unknown.

\section{HABITAT}

This species generally favours mixed mallee and heathland.

\section{BEHAVIOUR AND FLIGHT PERIOD}

Synemon sp. 'Mount Ragged' is a medium sized fast flying sun-moth. It is the only sun-moth species in Western Australia which commonly exhibits classic hill-topping behaviour; hence its common name. Males can readily be located at the summits of prominent hills, where they often fly together with other hill-topping butterflies. At Stirling Range National Park males commonly hill-top at the summit of the look out hill on Redgum Pass Road and on Mondurup Peak, and at Fitzgerald River National Park males hill-top at the summit of West Mount Barren. The male sun-moths fly

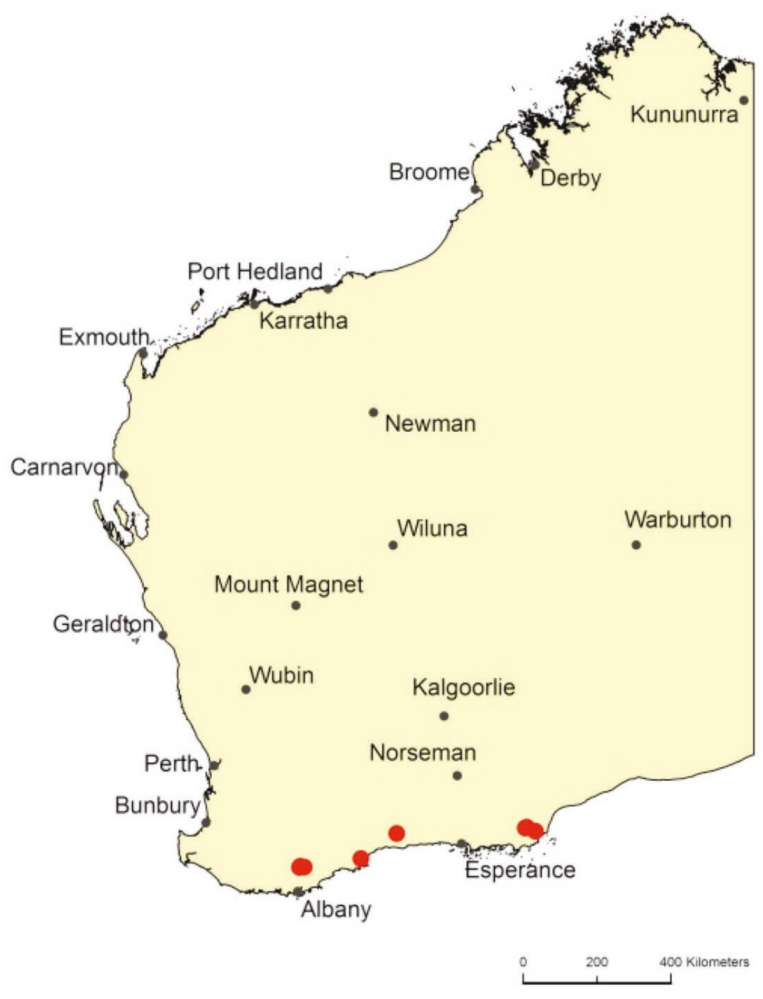

FIGURE 19 Map of Western Australia showing distribution of Synemon sp. 'Mount Ragged'. in sunny conditions, periodically settling on prominent shrubs at the tops of the hills. Females are rarely seen. Synemon sp. 'Mount Ragged' is on the wing in December and January.

\section{CONSERVATION STATUS}

Data deficient. Although this species is known from relatively few localities, most of these are in Western Australian conservation estate, so the species is probably secure. Targeted searches on prominent vegetated hilltops between Stirling Range National Park and Nuytsland Nature Reserve, and north into the Wheatbelt, would likely provide data on the species' overall distribution and areas of local abundance. There are seven historical and three recent records.

\section{HISTORICAL RECORDS}

Stirling Range National Park, $34^{\circ} 25^{\prime} 00^{\prime \prime} \mathrm{S}, 118^{\circ} 03^{\prime}$ 00" E, 13 Jan 1974, K.E. Carnaby; Mount Ragged, 33 $27^{\prime} 00^{\prime \prime} \mathrm{S}, 123^{\circ} 28^{\prime}$ 00" E, 10 Dec 1974, K.T. Richards (DAFC); 3 km SW of Mt Ragged, 33 28' 00" S, $123^{\circ} 26^{\prime}$ 00" E, 18 Dec 1989, R.P. Field; 20 km WNW of Israelite Bay, 33 33' 00" S, $123^{\circ} 41^{\prime}$ 00" E, 29 Dec 1990, M.S. Moulds and B.J. Moulds; $26 \mathrm{~km}$ E of Ravensthorpe, $33^{\circ}$ 36' 00" S, $120^{\circ} 18^{\prime} 00^{\prime \prime}$ E, 06 Jan 1993, E.D. Edwards and E.S. Nielsen; Stirling Range National Park, 34 29' 24" S, $117^{\circ}$ 57' 00" E, 28 Jan 1994, A.A.E. Williams; Cape Arid National Park, Mt Ragged, 33 $27^{\prime} 00^{\prime \prime}$ S, $123^{\circ} 28^{\prime}$ 00" E, 17 Dec 1995, M.S. Moulds.

\section{RECENT RECORDS}

Stirling Range National Park, $34^{\circ} 25^{\prime} 31^{\prime \prime}$ S, $117^{\circ} 56^{\prime}$ 06" E, 16 Dec 2004, A.A.E. Williams; Stirling Range National Park, $34^{\circ} 25^{\prime} 31^{\prime \prime}$ S, $117^{\circ} 56^{\prime} 06^{\prime \prime}$ E, 29 Dec 2009, A.A.E. Williams; Fitzgerald River National Park, $34^{\circ} 12^{\prime}$ 59" S, $119^{\circ} 25^{\prime}$ 59" E, 11 Jan 2015, A.A.E. Williams.

\section{Synemon sp. 'Perth' species complex (Common Spring Sun-moth)}

Figure 20

\section{BRIEF DESCRIPTION}

Synemon sp. 'Perth' species complex (hereafter referred to as Synemon sp. 'Perth') is a medium sized sun-moth. Males have an average wingspan of approximately $35 \mathrm{~mm}$ and females $40-45 \mathrm{~mm}$. In both sexes the upper side of the forewing is patterned in dark grey and black, invariably with small white subapical and median markings near the leading edge of the forewing. These white forewing spots are much more pronounced in females. The ground colour of the upper side of the hind wing is blackish-brown, the basal area with a prominent orange or orange-yellow discal spot. There is a band of orange or orange-yellow postmedian spots across the centre of the hind wing, the inner spot frequently 'tailing' into the inner margin next to the abdomen. The trailing edge of the hind wing has three or 
more small orange or orange-yellow subapical spots. The underside of the forewing has two broad dull orangeyellow bands and a row of pale yellowish spots along the outer margin. The underside of the hind wing has a similar pattern to the upper side, but is duller. This species has been widely misidentified as $S$. sophia.

\section{DISTRIBUTION}

Synemon sp. 'Perth' is a Western Australian endemic. The original specimens to which this interim nametag applies were collected on the Swan Coastal Plain near Perth and on the Darling Scarp round Mundaring
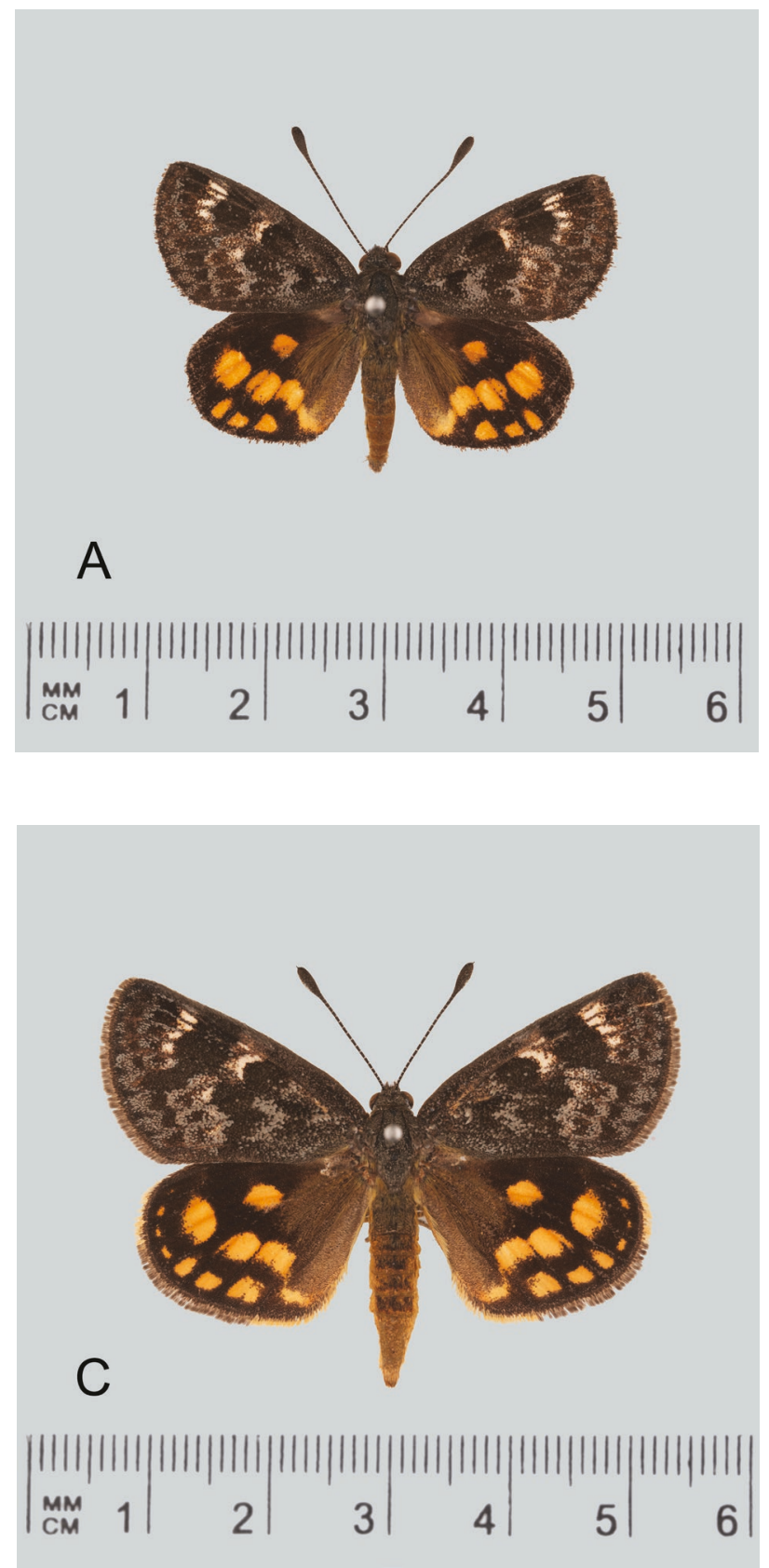

and Martin (ANIC Castniidae database). Since then, numerous specimens which appear to belong to this taxon have been obtained from a wide range of sites. New northern localities include Wicherina Reserve east of Geraldton, Mingenew Bushland, Badgingarra National Park and Watheroo National Park. The species has also been located in the northern and central Jarrah (Eucalyptus marginata) forest inland and south-east of Perth, and in nature conservation reserves in the Wheatbelt and semi-arid areas. To the south it has been located near Yournup and Cranbrook, and in Stirling Range National Park (Figure 21).
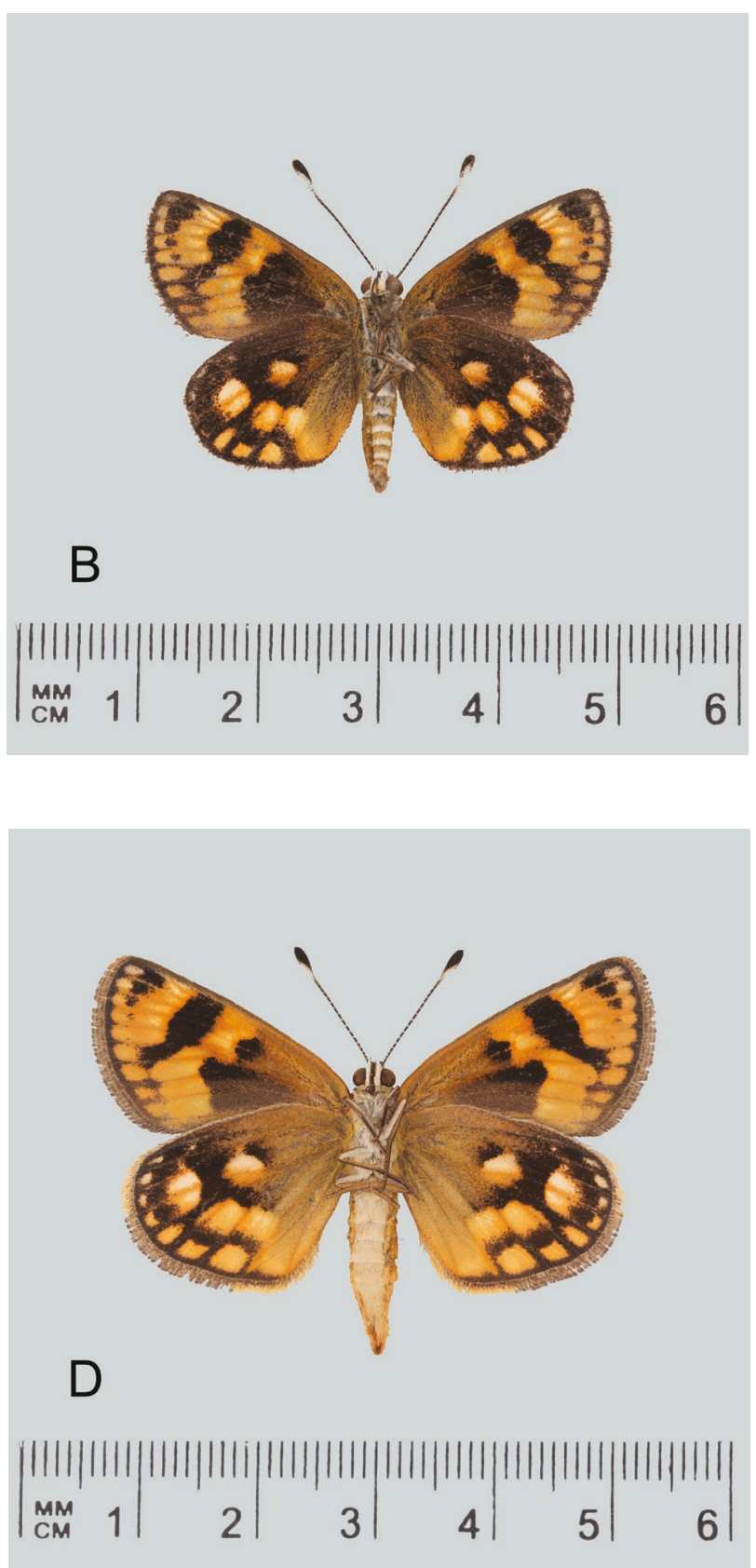

FIGURE 20 Synemon sp. 'Perth' species complex. A, §̊ Dorsal; B, ô Ventral (C2726) Western Australia, Koondoola (WAM); C, o Dorsal; D, o Ventral (C2720) Western Australia, Koondoola bushland (WAM). (Photos: Brian Hanich, Western Australian Museum.) 


\section{LARVAL FOOD PLANT}

The only documented larval food plant for $S$. sp. 'Perth' is the small semaphore sedge Mesomelaena pseudostygia (Kuek.) K.L. Wilson, at Koondoola Bushland, Perth (E.D. Edwards and A.A.E. Williams, personal observation, October 2013) (Russell Barrett identification, personal communication, 2014).

\section{HABITAT}

On the Swan Coastal Plain this species is found mainly in Banksia woodland where the understory is made up of low shrubs and sedges. On the Darling Scarp east and south-east of Perth, the sun-moths fly in open Jarrah (E. marginata), Marri (Corymbia calophylla) or Wandoo (Eucalyptus wandoo) dominated woodlands with mixed shrub and sedge understories. In the Wheatbelt and southern localities $S$. sp. 'Perth' generally favours open shrubland over low mixed heath and sedges.

\section{BEHAVIOUR AND FLIGHT PERIOD}

Synemon sp. 'Perth' is a common and conspicuous spring flying sun-moth which readily feeds at flowers (Williams et al. 2009). In the Banksia woodlands of the Swan Coastal Plain, males course over large areas of heath and sedges in search of unmated females. Mated gravid females oviposit at the bases of common narrowleafed sedges. The flight period of $S$. sp. 'Perth' varies according to location. Sun-moths in the northernmost part of the range emerge in October. In the vicinity of Perth the species normally flies in November, except after a fire, when they emerge much earlier and may be abundant in October. In newly burnt areas, $S$. sp. 'Perth' appears to temporarily displace $S$. sp. 'Yarloop', which round Perth is normally the first spring flying sun-moth to appear. South of Perth $S$. sp. 'Perth' flies in November, while in the inland forest belt the flight period extends from mid-November to December. In the Wheatbelt and semi-arid zone the species flies in October and November.

\section{CONSERVATION STATUS}

Not threatened. This species is widespread, locally common, and well represented in the conservation estate. There are 18 historical and 94 recent records.

\section{HISTORICAL RECORDS}

2 miles $\mathrm{N}$ of Armadale, $32^{\circ} 07^{\prime} 00^{\prime \prime} \mathrm{S}, 116^{\circ} 00^{\prime} 00^{\prime \prime}$ E, 12 Nov 1966, L.E. Couchman; Boorabbin Rock, $31^{\circ}$ 07' 12" S, $120^{\circ} 10^{\prime}$ 12" E, 4-9 Oct 1981, T.F. Houston (WAM); Martin, 32 04' 38" S, $116^{\circ} 01^{\prime} 33^{\prime \prime}$ E, 27 Nov 1986, R.W. Hay; Bedfordale, $32^{\circ} 10^{\prime} 00^{\prime \prime}$ S, $116^{\circ} 03^{\prime}$ 00" E, 21 Nov 1987, R.W. Hay; Mundaring, 31 ${ }^{\circ} 54^{\prime}$ 00" S, 116 10' 00" E, 04 Dec 1988, R.W. Hay; Perth, Mundaring, $31^{\circ} 58^{\prime} 23^{\prime \prime}$ S, $116^{\circ} 07^{\prime}$ 46" E, 04 Nov 1990 ,
M.R. Williams; Paul's Valley Road, Mundaring, $31^{\circ}$ 54' 00" S, $116^{\circ} 10^{\prime} 00^{\prime \prime}$ E, 15 Nov 1991, L.E. Ring;

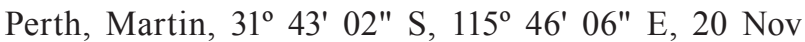
1991, M.R. Williams; Mundaring, 32 07' 28" S, $116^{\circ} 17^{\prime}$ 42" E, 20 Nov 1991, M.R. Williams; Perth, Mirrabooka, 31 ${ }^{\circ} 51^{\prime} 37^{\prime \prime}$ S, $115^{\circ}$ 52' 37" E, 13 Dec 1991, M.R. Williams; Dwellingup, 32 41' 29" S, $116^{\circ} 03^{\prime}$ 01" E, 20 Dec 1991, M.R. Williams; Perth, Gooseberry

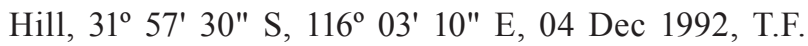
Houston (WAM); Quairading Bushland, 32 01' 13" S, $117^{\circ} 22^{\prime} 12^{\prime \prime}$ E, 10 Oct 1994, A.A.E. Williams; Watheroo National Park, 30 $19^{\prime} 00^{\prime \prime}$ S, $115^{\circ} 46^{\prime} 00^{\prime \prime}$ E, 11 Oct 1994, M.R. Williams; Perth, Neerabup National Park, 31 43' 02" S, $115^{\circ} 46^{\prime}$ 06" E, 16 Oct 1994, M.R. Williams; Quairading Bushland, 32 ${ }^{\circ} 01^{\prime} 17^{\prime \prime} \mathrm{S}, 117^{\circ} 23^{\prime}$ 17" E, 24 Oct 1995, M.R. Williams; Perth, Neerabup, Flynn Drive, 31 41' 11" S, 115º 47' 49" E, 11 Nov 1995, T.F. Houston (WAM); Stirling Range National Park, $34^{\circ} 28^{\prime} 00^{\prime \prime} \mathrm{S}, 118^{\circ} 03^{\prime} 40^{\prime \prime} \mathrm{E}, 03$ Dec 1999, A.A.E. Williams.

\section{RECENT RECORDS}

\section{Northern localities}

Mount Gibson Station, 29 22' 36" S, 117 19' 52" E, 14 Oct 2001, S.R. Patterson (ANIC); Mount Gibson Station, $29^{\circ} 22^{\prime} 36^{\prime \prime}$ S, $117^{\circ} 19^{\prime}$ 52" E, 03 Oct 2002, S.R. Patterson (ANIC); Watheroo National Park, 30 ${ }^{\circ} 1^{\prime}$ 04" S, 115 46' 56" E, 09 Oct 2008, A.A.E. Williams; Watheroo National Park, $30^{\circ} 19^{\prime} 08^{\prime \prime}$ S, $115^{\circ} 04^{\prime} 56^{\prime \prime}$ E, 23 Oct 2009, A.A.E. Williams; Badgingarra National Park, $30^{\circ} 32^{\prime} 55^{\prime \prime}$ S, $115^{\circ} 29^{\prime} 48^{\prime \prime}$ E, 23 Oct 2009, A.A.E. Williams; Wicherina Reserve, $28^{\circ} 44^{\prime} 00^{\prime \prime} \mathrm{S}, 115^{\circ}$ 01' 02" E, 09 Oct 2010, A.A.E. Williams; Mingenew Bushland, 29 $12^{\prime} 38^{\prime \prime} \mathrm{S}, 115^{\circ} 26^{\prime} 39^{\prime \prime}$ E, 16 Oct 2010, A.A.E. Williams; Enneabba, $29^{\circ} 47^{\prime}$ 14" S, $115^{\circ} 16^{\prime} 02^{\prime \prime}$ E, 25 Oct 2010, A.A.E. Williams; Boonanaring Nature Reserve, 31 $12^{\prime}$ 53" S, $115^{\circ} 52^{\prime} 56^{\prime \prime}$ E, 15 Oct 2011, A.A.E. Williams; Calingiri, Fordham Road, Bolgart, $31^{\circ} 09^{\prime} 36^{\prime \prime}$ S, $116^{\circ} 29^{\prime} 30^{\prime \prime}$ E, 19 Nov 2011, F. Hort and J. Hort; Wyening, Fordham Road, Bolgart, 31 $11^{\circ}$ ' 23" S, $116^{\circ} 29^{\prime}$ 04" E, 19 Nov 2011, F. Hort and J. Hort; Lancelin, $20 \mathrm{~km} \mathrm{~N}$ of town, $30^{\circ} 52^{\prime} 20^{\prime \prime} \mathrm{S}, 115^{\circ} 21^{\prime}$ 59" E, 10 Nov 2012, C.G. Miller; Alexander Morrison National Park, $30^{\circ} 03^{\prime} 2^{\prime \prime}$ S, $115^{\circ} 40^{\prime} 27^{\prime \prime}$ E, 16 Oct 2015, A.A.E. Williams; Buntine Water Reserve, $29^{\circ}$ 58' 53" S, $116^{\circ} 34^{\prime} 10^{\prime \prime}$ E, 16 Oct 2016, J. Hort; Lesueur National Park, Mount Peron, $30^{\circ} 06^{\prime} 43^{\prime \prime}$ S, $115^{\circ} 09^{\prime} 05^{\prime \prime}$ E, 23 Nov 2016, A.A.E. Williams.

\section{Perth area}

Muchea, Ioppolo Road, $31^{\circ} 28^{\prime} 30^{\prime \prime} \mathrm{S}, 115^{\circ} 59^{\prime} 56^{\prime \prime}$ E, 24 Oct 2000, A.A.E. Williams; Muchea, Ioppolo Road, 31 $28^{\prime} 30^{\prime \prime}$ S, $115^{\circ} 59^{\prime} 56^{\prime \prime}$ E, 24 Oct 2000, A.A.E. Williams; Perth, Warwick, $31^{\circ} 50^{\prime} 08^{\prime \prime} \mathrm{S}, 115^{\circ}$ 48' 59" E, 13 Nov 2002, M.R. Williams; Perth, Trigg 


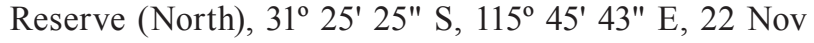
2002, M.R. Williams; Perth, Banksia Grove, 31 ${ }^{\circ} 42^{\prime}$ $20^{\prime \prime}$ S, $115^{\circ} 48^{\prime} 13^{\prime \prime}$ E, 26 Nov 2002, A.A.E. Williams; Perth, Talbot Road Reserve, 31 31' 36" S, $115^{\circ} 41^{\prime} 15^{\prime \prime}$ E, 15 Oct 2009, F. Hort and J. Hort; Yanchep National Park, 31 31' 36" S, $115^{\circ} 41^{\prime} 15^{\prime \prime}$ E, 15 Oct 2009, A.A.E. Williams; Perth, Banksia Grove, $31^{\circ} 41^{\prime} 42^{\prime \prime} \mathrm{S}, 115^{\circ}$ 48' 46" E, 15 Nov 2009, A.A.E. Williams; Perth, Neerabup, Flynn Drive, $31^{\circ} 41^{\prime} 11^{\prime \prime}$ S, $115^{\circ} 47^{\prime} 49^{\prime \prime}$ E, 15 Nov 2009, A.A.E. Williams; Perth, Old Yanchep Road, $31^{\circ} 33^{\prime} 30^{\prime \prime}$ S, $115^{\circ} 41^{\prime} 43^{\prime \prime}$ E, 21 Nov 2009, A.A.E. Williams; Perth, Wanneroo, Yanchep Road, 31 ${ }^{\circ} 39^{\prime}$ 04" S, 115 44' 05" E, 21 Nov 2009, A.A.E. Williams;

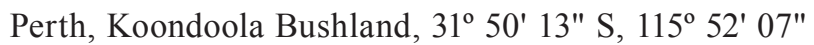
E, 29 Octo 2010, A.A.E. Williams; Chittering, Reserve Road, 31' 29' 31" S, $115^{\circ} 59^{\prime}$ 52" E, 31 Octo 2010, F. Hort and J. Hort; Muchea, Ioppolo Nature Reserve, $31^{\circ}$ 29' 15" S, $115^{\circ} 58^{\prime}$ 13" E, 04 Nov 2010, F. Hort and J. Hort; Perth, Koondoola Bushland, 31 $51^{\circ}$ 07" S, $115^{\circ}$ 52' 11" E, 17 Oct 2012, A.A.E. Williams; Yanchep, Wabling Road, $31^{\circ} 25^{\prime} 00^{\prime \prime} \mathrm{S}, 115^{\circ} 39^{\prime} 00^{\prime \prime} \mathrm{E}, 08 \mathrm{Nov}$ 2012, C.G. Miller; Perth, Errina Road Reserve, $31^{\circ} 49^{\prime}$ 38" S, $116^{\circ}$ 51' 34" E, 12 Nov 2012, A.A.E. Williams; Perth, Koondoola Bushland, $31^{\circ}$ 50' 13" S, $115^{\circ} 52^{\prime}$ 07" E, 12 Nov 2012, A.A.E. Williams; Perth, Koondoola Bushland, 31 50' 13" S, 115 52' 07" E, 05 Dec 2012, A.A.E. Williams; Perth, Talbot Road Reserve, $31^{\circ} 52^{\prime}$ 24" S, $116^{\circ} 02^{\prime} 32^{\prime \prime}$ E, 16 Dec 2012, A.A.E. Williams.

\section{Inland Jarrah / Marri / Wandoo forest}

Dryandra State Forest, $32^{\circ} 45^{\prime} 29^{\prime \prime} \mathrm{S}, 116^{\circ} 56^{\prime} 50^{\prime \prime}$ E, 15 Nov 2006, A.A.E. Williams; $6 \mathrm{~km}$ E of North Bannister, 32 34' 50" S, 116 30' 34" E, 27 Nov 2006, A.A.E. Williams; Narrogin, Quinns Forest Block, $33^{\circ} 08^{\prime} 08^{\prime \prime}$ S, $117^{\circ} 04^{\prime} 43^{\prime \prime}$ E, 25 Nov 2008, A.A.E. Williams; Mount Dale, Dale Road, $32^{\circ} 06^{\prime} 01^{\prime \prime} \mathrm{S}, 116^{\circ}$ 13' 41" E, 14 Nov 2009, A.A.E. Williams; Narrogin, Highbury Forest Block, 33 04' 39" S, $117^{\circ} 06^{\prime}$ 53" E, 16 Nov 2009, A.A.E. Williams; Narrogin, Quinns Forest Block, 33 07' 34" S, $117^{\circ} 04^{\prime} 21^{\prime \prime}$ E, 16 Nov 2009, A.A.E. Williams; Powerline Road, Albany Highway, 32 28' 03" S, 116 ${ }^{\circ} 19^{\prime} 08^{\prime \prime}$ E, 23 Nov 2009, A.A.E. Williams; Tutanning Nature Reserve, 32 $32^{\prime}$ 09" S, $117^{\circ} 16^{\prime} 42^{\prime \prime}$ E, 24 Nov 2009, A.A.E. Williams; Dryandra State Forest, 32 ${ }^{\circ} 43^{\prime} 53^{\prime \prime} \mathrm{S}, 116^{\circ} 57^{\prime} 10^{\prime \prime} \mathrm{E}$, 26 Nov 2009, A.A.E. Williams; Brookton Highway, $32^{\circ} 15^{\prime} 31^{\prime \prime} \mathrm{S}, 116^{\circ} 28^{\prime} 48^{\prime \prime} \mathrm{E}, 27$ Nov 2009, A.A.E. Williams; Mount Dale, 320 07' 28" S, 116 $17^{\circ}$ ' 42" E, 27 Nov 2009, A.A.E. Williams; $20 \mathrm{~km}$ SE of Armadale, $32^{\circ} 22^{\prime} 16^{\prime \prime}$ S, $116^{\circ} 14^{\prime} 16^{\prime \prime}$ E, 28 Nov 2009, A.A.E. Williams; Watershed Road, Brookton Highway, $32^{\circ}$ 16' 22" S, $116^{\circ} 25^{\prime} 31^{\prime \prime}$ E, 02 Dec 2009, F. Hort and J. Hort; Brookton Highway, 32 09' 11" S, $116^{\circ} 09^{\prime} 14^{\prime \prime}$ E, 05 Dec 2009, A.A.E. Williams; Armadale, Boundary Road, 32 $13^{\prime} 54^{\prime \prime} \mathrm{S}, 116^{\circ} 16^{\prime} 17^{\prime \prime}$ E, 14 Dec 2009, F.
Hort and J. Hort; Wandering, Canning River Road, $32^{\circ}$ $25^{\prime} 20^{\prime \prime}$ S, $116^{\circ} 23^{\prime}$ 03" E, 20 Dec 2009, F. Hort and J. Hort; Brookton Highway, Bibbulmun, 32 $12^{\prime} 08^{\prime \prime} \mathrm{S}$, $116^{\circ} 17^{\prime}$ 37" E, 23 Dec 2009, A.A.E. Williams; Great Eastern Highway, The Lakes, $31^{\circ} 52^{\prime} 48^{\prime \prime}$ S, $116^{\circ} 19^{\prime}$ 38" E, 30 Oct 2010, A.A.E. Williams; Mount Dale, Dale Road, 32 06' 23" S, $116^{\circ} 12^{\prime} 41^{\prime \prime}$ E, 18 Dec 2010, F. Hort and J. Hort; Clair State Forest, Rutherglen Road, 31 $14^{\circ}$ 03" S, $116^{\circ} 16^{\prime} 32^{\prime \prime}$ E, 18 Dec 2010, F. Hort and J. Hort; Armadale Forest, Permit Road, $32^{\circ}$ 06' 09" S, $116^{\circ} 12^{\prime}$ 54" E, 18 Dec 2010, F. Hort and J. Hort; Wandoo National Park, 32 ${ }^{\circ} 06^{\prime} 18^{\prime \prime}$ S, $116^{\circ} 34^{\prime}$ 32" E, 20 Nov 2011, F. Hort and J. Hort; Sullivan Rock, $32^{\circ} 22^{\prime} 36^{\prime \prime}$ S, $116^{\circ} 15^{\prime} 08^{\prime \prime}$ E, 02 Dec 2011, A.A.E. Williams; Sullivan Rock, Millars Log Road, $32^{\circ} 21^{\prime}$ 55" S, 116 16' 28" E, 02 Dec 2011, A.A.E. Williams; Blue Rock, ENE of Jarrahdale, $32^{\circ} 19^{\prime} 40^{\prime \prime}$ S, $116^{\circ} 06^{\prime}$ 52" E, 16 Dec 2011, A.A.E. Williams; $1.6 \mathrm{~km} \mathrm{NW}$ of Sullivan Rock, $32^{\circ} 22^{\prime} 16^{\prime \prime} \mathrm{S}, 116^{\circ} 14^{\prime} 16^{\prime \prime}$ E, 22 Dec 2011, A.A.E. Williams; Metro Road off Brookton Hwy, 32 14' 55" S, $116^{\circ} 26^{\prime}$ 48" E, 27 Dec 2011, A.A.E. Williams; Mount Dale at Bibbulmun Hut, $32^{\circ}$ 07' 56" S, $116^{\circ} 17^{\prime} 47^{\prime \prime}$ E, 10 Jan 2012, A.A.E. Williams;

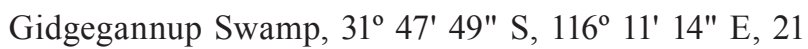
Nov 2012, A.A.E. Williams; $7.5 \mathrm{~km} \mathrm{~S}$ of Yournup, $34^{\circ}$ 07' 29" S, 116 $12^{\circ}$ ' 15" E, 20 Nov 2013, M.R. Williams.

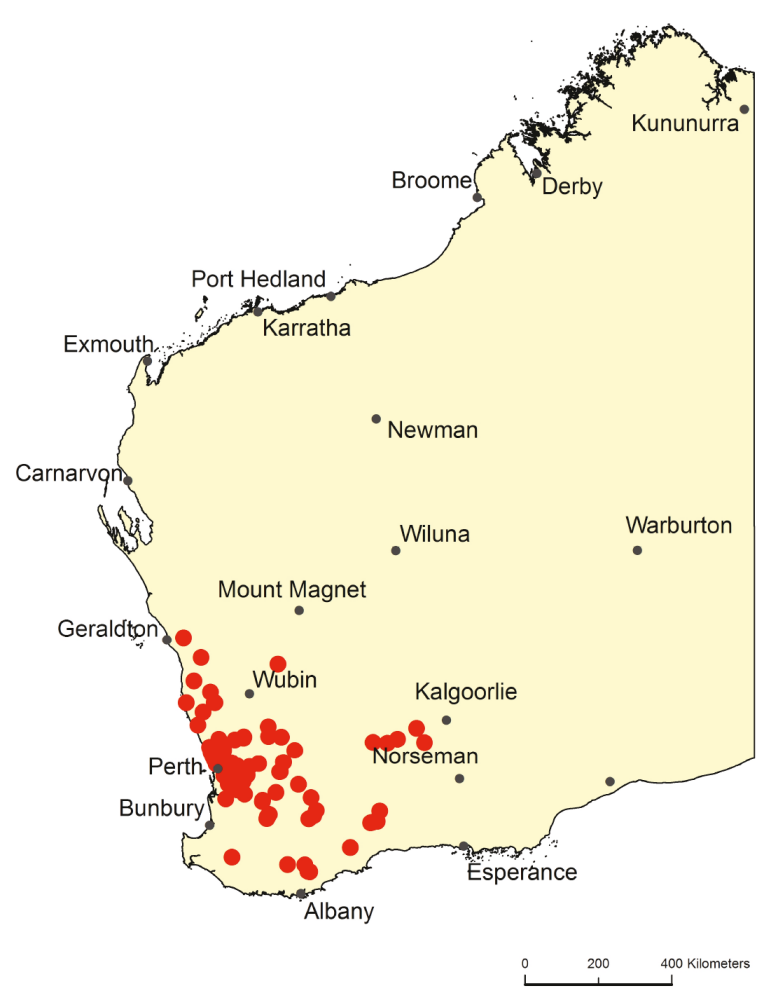

FIGURE 21 Map of Western Australia showing distribution of Synemon sp. 'Perth' species complex. 


\section{Wheatbelt}

Torino Farm, SE of Williams, $33^{\circ} 10^{\prime} 33^{\prime \prime} \mathrm{S}, 117^{\circ}$ 03' 29" E, 05 Nov 2003, T.F. Houston; Wyalkatchem Nature Reserve, $31^{\circ} 10^{\prime} 14^{\prime \prime}$ S, $117^{\circ} 24^{\prime} 49^{\prime \prime}$ E, 23 Oct 2007, A.A.E. Williams; Manmanning Nature Reserve, $30^{\circ} 54^{\prime} 49^{\prime \prime} \mathrm{S}, 117^{\circ} 05^{\prime} 38^{\prime \prime}$ E, 30 Oct 2009, A.A.E. Williams; Amery Nature Reserve, $31^{\circ} 09^{\prime}$ 01" S, $117^{\circ} 05^{\prime} 47^{\prime \prime}$ E, 30 Oct 2009, A.A.E. Williams; Charles Gardner Nature Reserve, $31^{\circ} 47^{\prime} 24^{\prime \prime}$ S, $117^{\circ}$ 28' 03" E, 05 Oct 2010, A.A.E. Williams; Bencubbin Kellerberrin Road, 31 $29^{\circ} 42^{\prime \prime}$ S, $117^{\circ} 44^{\prime} 18^{\prime \prime}$ E, 18 Oct 2010, A.A.E. Williams; Quairading Bushland, $32^{\circ} 01^{\prime}$ $29^{\prime \prime}$ S, $117^{\circ} 22^{\prime} 12^{\prime \prime}$ E, 18 Oct 2010, A.A.E. Williams; Wambyn Nature Reserve, $31^{\circ} 54^{\prime}$ 02" S, $116^{\circ} 38^{\prime} 08^{\prime \prime}$ E, 30 Oct 2010, A.A.E. Williams, F. Hort and J. Hort; Corrigin Bushland, 32 20' 18" S, $117^{\circ} 49^{\prime} 55^{\prime \prime}$ E, 01 Nov 2010, A.A.E. Williams; Newdegate Town site, $33^{\circ} 07^{\prime} 34^{\prime \prime} \mathrm{S}, 117^{\circ} 04^{\prime} 21^{\prime \prime}$ E, 02 Nov 2010, A.A.E. Williams; Pallarup Nature Reserve, $33^{\circ} 14^{\prime} 31^{\prime \prime}$ S, $119^{\circ}$ 45' 42" E, 02 Nov 2010, A.A.E. Williams; Bennett's Lake, 33 16' 49" S, $119^{\circ} 36^{\prime} 10^{\prime \prime}$ E, 02 Nov 2010, A.A.E. Williams; Old Newdegate Road, $33^{\circ} 16^{\prime} 17^{\prime \prime} \mathrm{S}$, $119^{\circ} 38^{\prime} 38^{\prime \prime}$ E, 02 Nov 2010, A.A.E. Williams; Kulin Bushland, 32 39' 49" S, $118^{\circ} 08^{\prime}$ 28" E, 08 Nov 2010, A.A.E. Williams; Kukerin Bushland, $33^{\circ} 10^{\prime}$ 58" S, $118^{\circ} 05^{\prime} 00^{\prime \prime}$ E, 08 Nov 2010, A.A.E. Williams; Charles Gardner Nature Reserve, $31^{\circ} 47^{\prime} 27^{\prime \prime}$ S, $117^{\circ} 27^{\prime} 51^{\prime \prime}$ E, 12 Nov 2011, A.A.E. Williams; Tarin Rock Nature Reserve, 33 06' 28" S, $118^{\circ} 12^{\prime}$ 25" E, 21 Nov 2011, A.A.E. Williams; Lake Ace Nature Reserve, 32 ${ }^{\circ} 9^{\prime}$ 33" S, $119^{\circ} 49^{\prime}$ 32" E, 22 Nov 2011, A.A.E. Williams; Corrigin Bushland, 32 20' 18" S, 117 49' 50" E, 23 Nov 2011, A.A.E. Williams; Wyalkatchem Water Catchment, 31 ${ }^{\circ}$ 10' 14" S, $117^{\circ} 24^{\prime}$ 49" E, 03 Nov 2012, A.A.E. Williams; North Tarin Rock Nature Reserve, $32^{\circ} 58^{\prime}$ 52" S, $118^{\circ} 16^{\prime} 01^{\prime \prime}$ E, 08 Nov 2012, A.A.E. Williams.

\section{Eastern Wheatbelt / Semi-arid zone}

$95 \mathrm{~km} \mathrm{E}$ of Southern Cross, $31^{\circ} 12^{\prime} 47^{\prime \prime} \mathrm{S}, 120^{\circ} 15^{\prime}$ 32" E, 20 Oct 2010, A.A.E. Williams; Yellowdine Nature Reserve, 31 $1^{\circ} 17^{\prime} 43^{\prime \prime} \mathrm{S}, 119^{\circ} 39^{\prime}$ 33" E, 21 Oct 2010, A.A.E. Williams; Queen Victoria Rock, $31^{\circ} 18^{\prime}$ 03" S, $120^{\circ} 55^{\prime}$ 09" E, 21 Oct 2010, A.A.E. Williams; Koorarawalyea, $31^{\circ} 18^{\prime} 39^{\prime \prime} \mathrm{S}, 120^{\circ} 00^{\prime} 34^{\prime \prime}$ E, 20 Oct 2012, T.F. Houston; $1 \mathrm{~km}$ SE of Caenyie Rock, 30 $57^{\circ}$ 03" S, $120^{\circ} 43^{\prime} 33^{\prime \prime}$ E, 12 Oct 2015, A.A.E. Williams.

\section{Southern localities}

Camel Lake Nature Reserve, $34^{\circ} 18^{\prime} 37^{\prime \prime} \mathrm{S}, 117^{\circ}$ 59' 15" E, 13 Nov 2010, A.A.E. Williams; Cranbrook Bushland, 34 18' 24" S, $117^{\circ} 33^{\prime}$ 55" E, 19 Nov 2010, A.A.E. Williams; Stirling Range National Park, 34 $28^{\prime}$ 44" S, $118^{\circ} 06^{\prime} 36^{\prime \prime}$ E, 25 Nov 2010, A.A.E. Williams.

\section{Synemon sp. 'Yarloop' (Orange-banded Sun-moth)}

Figure 22

\section{BRIEF DESCRIPTION}

Synemon sp. 'Yarloop' is a distinctive species. The upper side of the forewing is grey with blackish markings. A patch of white subapical spots, and a less obvious white median spot, are located near the leading edge of the forewing. These are more pronounced in females. The base colour on the upper side of the hind wing is black. A series of large, usually fused, postmedian orange spots form a broad band across the lower portion of the hind wing. The outer margin of the hind wing also has a row of smaller orange subterminal spots. An isolated distinct orange discal spot lies within the basal area of the hind wing. The underside of the forewing has two very broad parallel orange bands, which in females extend across the wing. The outer band is usually fused with a row of small orange terminal spots along the outer edge of the forewing. The pattern on the underside of the hind wing is similar to the upper side, but somewhat duller.

\section{DISTRIBUTION}

Synemon sp. 'Yarloop' is a Western Australian endemic. It has a near-coastal distribution from Badgingarra south to a point $13 \mathrm{~km}$ north-north-east of Bunbury. Pre-2000, this taxon was known from a few localities round Perth, and from Yarloop and near Bunbury (ANIC Castniidae database). In recent years specimens have been taken $175 \mathrm{kms}$ further north at Badgingarra National Park, and at Muchea and Talbot Road Nature Reserve at the base of the Darling Scarp (Figure 23). Although Yarloop is the earliest dated collection site, the species has not been seen there for almost 70 years.

\section{LARVAL FOOD PLANT}

The larval food plant has not been recorded.

\section{HABITAT}

This species is found in a variety of habitats, almost always on sandy soils. At Badgingarra National Park it occurs in species rich low heath, while at Boonanaring Nature Reserve it is found in mixed Coastal Blackbutt (Eucalyptus todtiana) and Firewood Banksia (Banksia menziesii) woodland. Near Moore River National Park, in the vicinity of Perth, and further south near Bunbury, it favours mixed Slender Banksia (Banksia attenuata) and Firewood Banksia (B. menziesii) woodlands.

\section{BEHAVIOUR AND FLIGHT PERIOD}

This is a conspicuous species. It flies moderately close to the ground amongst understory shrubs and sedges in open woodland. Males will often use vehicle sand tracks and natural passages through the vegetation as flight 
pathways. Synemon sp. 'Yarloop' flies in October or very early November. It is usually the first spring flying sunmoth to appear, except immediately after a fire, at which time Synemon sp. 'Perth' takes its place.

\section{CONSERVATION STATUS}

Not threatened. Although this taxon has a somewhat restricted range, it is locally common in near-coastal areas north and south of Perth, and is represented in national parks, nature reserves, and in nature conservation bushland round Perth. There are seven historical and 16 recent records.
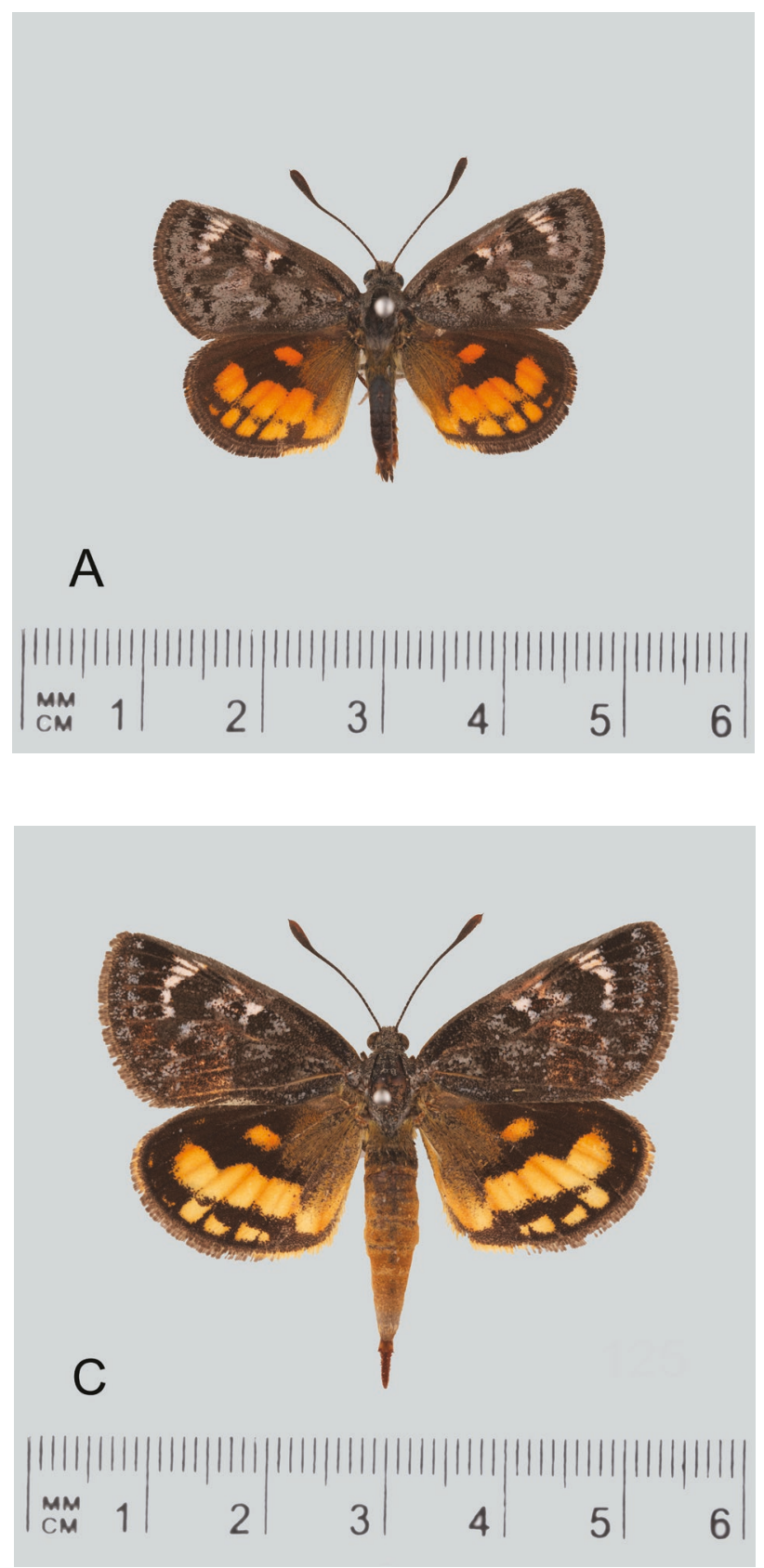

\section{HISTORICAL RECORDS}

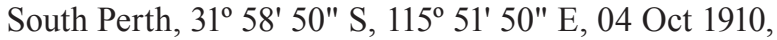
collector not recorded (WAM); Yarloop, 32 $57^{\prime} 00^{\prime \prime} \mathrm{S}$, $115^{\circ} 54^{\prime} 00^{\prime \prime}$ E, 08 Nov 1948, F.E. Wilson; Leeming, $32^{\circ} 05^{\prime} 00^{\prime \prime} \mathrm{S}, 115^{\circ} 51^{\prime} 00^{\prime \prime}$ E, 15 Oct 1982, H. Bollam; Mundaring, $31^{\circ} 54^{\prime} 00^{\prime \prime} \mathrm{S}, 116^{\circ} 10^{\prime} 00^{\prime \prime} \mathrm{E}, 22$ Oct 1985 , R.W. Hay; Perth, Warwick, $31^{\circ} 57^{\prime} 00^{\prime \prime} \mathrm{S}, 115^{\circ} 51^{\prime} 00^{\prime \prime}$ E, 24 Oct 1986, R.W. Hay; $13 \mathrm{~km}$ NNE of Bunbury, 33 13' 52" S, 115 43' 45" E, 04 Nov 1993, M.R. Williams; Perth, Koondoola Reserve, $31^{\circ} 50^{\prime} 00^{\prime \prime} \mathrm{S}, 115^{\circ} 45^{\prime} 00^{\prime \prime} \mathrm{E}$, 18 Oct 1999, D.P.A. Sands.
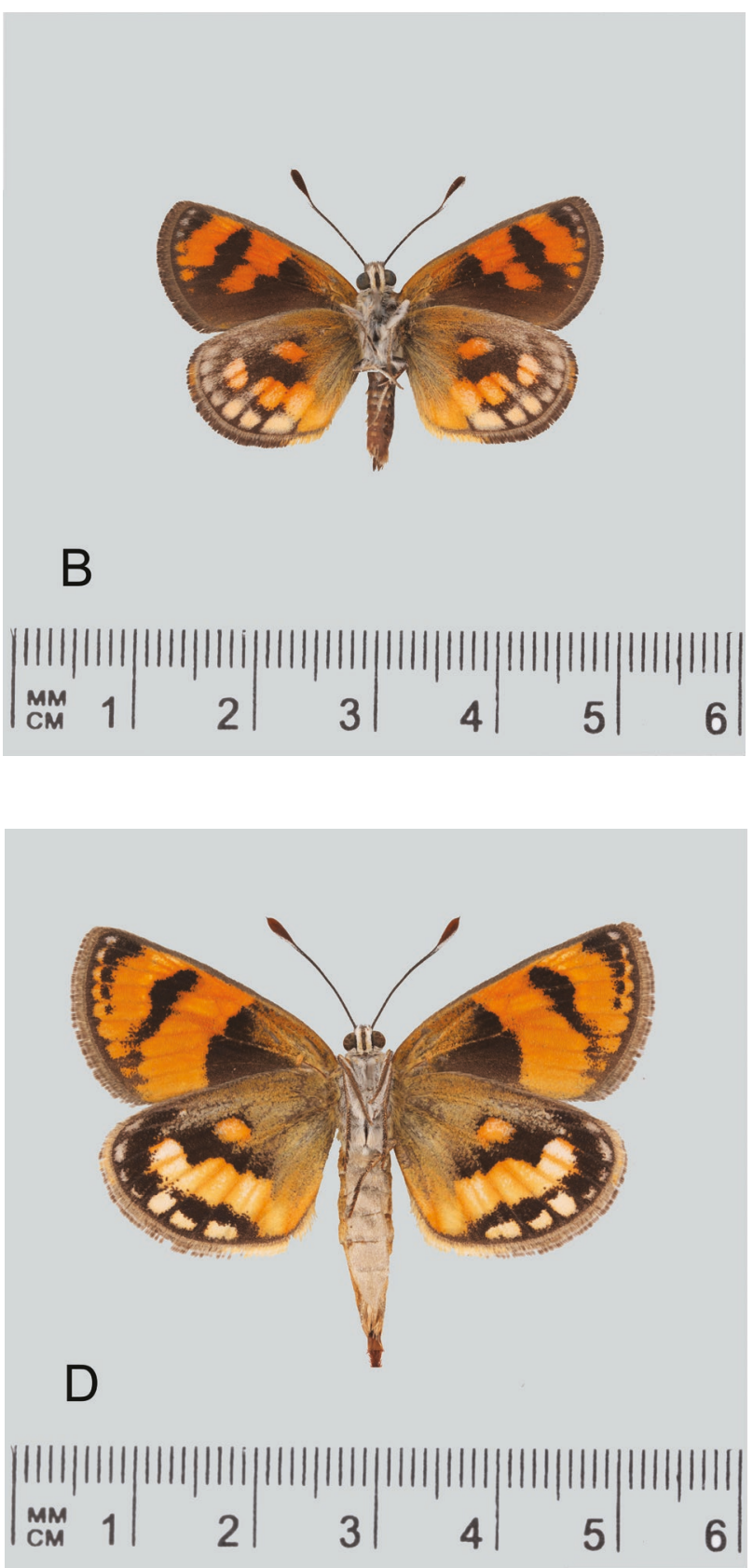

FIGURE 22 Synemon sp. 'Yarloop'. A, $\hat{\jmath}$ Dorsal; B, $\hat{o}$ Ventral (C0769) Western Australia, Muchea (WAM); C, o Dorsal; D, o Ventral (C1935) Western Australia, Boonanaring Nature Reserve (WAM). (Photos: Brian Hanich, Western Australian Museum.) 


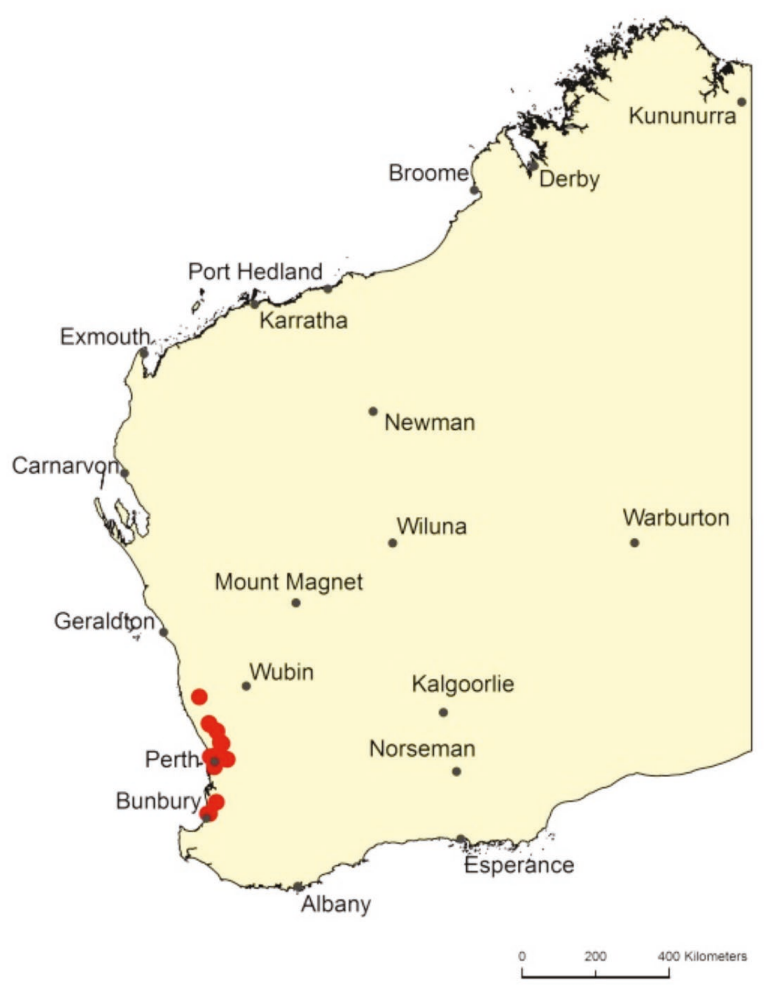

FIGURE 23 Map of Western Australia showing distribution of Synemon sp. 'Yarloop'.

\section{RECENT RECORDS}

Badgingarra National Park, $30^{\circ} 22^{\prime} 00^{\prime \prime} \mathrm{S}, 115^{\circ} 28^{\prime} 47^{\prime \prime}$ E, 23 Oct 2009, A.A.E. Williams; Boonanaring Nature Reserve, $31^{\circ} 12^{\prime} 41^{\prime \prime}$ S, $115^{\circ} 54^{\prime} 34^{\prime \prime}$ E, 15 Oct 2011, A.A.E. Williams; Boonanaring Nature Reserve, $31^{\circ} 12^{\prime}$ 24" S, $115^{\circ} 54^{\prime} 35^{\prime \prime}$ E, 06 Oct 2012, F. Hort and J. Hort; 2 km N Moore River National Park, 31 $01^{\prime}$ 04" S, $115^{\circ}$ 43' 12" E, 07 Oct 2010, A.A.E. Williams; 2 km N Moore River National Park, 31 ${ }^{\circ} 01^{\prime}$ 04" S, $115^{\circ} 43^{\prime} 12^{\prime \prime}$ E, 15 Oct 2011, A.A.E. Williams; Moore River National Park, $31^{\circ}$ 02' 29" S, 115 43' 45" E, 25 Oct 2013, A.A.E. Williams; Muchea, Great Northern Highway, 31 30' 36" S, $116^{\circ} 02^{\prime}$ 13" E, 15 Oct 2011, A.A.E. Williams; Muchea, Ioppolo Road, 31 28' 45" S, $115^{\circ} 59^{\prime}$ 52" E, 17 Oct 2008, A.A.E. Williams; Muchea, Ioppolo Road, 31 28' 44" S, $115^{\circ} 59^{\prime}$ 54" E, 01 Oct 2010, A.A.E. Williams; Muchea, Reserve Road, 31 28' 58" S, $115^{\circ} 59^{\prime}$ 55" E, 01 Oct 2010, A.A.E. Williams; Perth, Gnangara Bushland, 31 ${ }^{\circ} 48^{\prime} 27^{\prime \prime} \mathrm{S}$, $115^{\circ} 52^{\prime} 37^{\prime \prime}$ E, 10 Oct 2003, A.A.E. Williams; Perth, Landsdale Reserve, $31^{\circ} 49^{\prime} 10^{\prime \prime} \mathrm{S}, 115^{\circ} 50^{\prime} 53^{\prime \prime} \mathrm{E}, 18$ Oct 2012, A.A.E. Williams; Perth, Marangaroo Reserve, $31^{\circ}$ 49' 29" S, 115 50' 08" E, 07 Oct 2011, A.A.E. Williams; Perth, Errina Road Reserve, 31 28' 58" S, $115^{\circ} 59^{\prime} 55^{\prime \prime}$ E, 02 Nov 2009, C.L. Bishop, T. Gamblin and M. Williams; Perth, Koondoola Bushland, $31^{\circ} 50^{\prime} 14^{\prime \prime} \mathrm{S}, 115^{\circ} 52^{\prime}$ 07" E, 12 Oct 2008, A.A.E. Williams; Perth, Talbot Road Reserve, $31^{\circ} 52^{\prime} 27^{\prime \prime} \mathrm{S}, 116^{\circ} 02^{\prime} 42^{\prime \prime} \mathrm{E}, 14$ Oct 2012, F. Hort and J. Hort.

\section{Synemon directa species group \\ Synemon directa Westwood 1877 (White-banded Sun-moth)}

Figure 24

\section{BRIEF DESCRIPTION}

Synemon directa is a large, distinctively marked sun-moth. In both sexes, the upper side of the forewing is uniform grey-brown, females having two oblique white bands and males (usually) one. The upper side of the hind wing is dark grey-brown, with bright orange markings that are more pronounced in females. The female underside is also bright orange-brown, with narrow dark markings. Males are much darker below.

\section{DISTRIBUTION}

Synemon directa is a Western Australian endemic. It has a predominantly near-coastal distribution in the south-west and south of the State. The species has been recorded from the Swan River southwards to Dunsborough and Eagle Bay, and eastwards to Walpole, Denmark and Albany. It has been found as far inland as Mount Dale and North Bannister, as well as from Hoffman's Mill and Stirling Range National Park. A single specimen is known from east of Esperance, at Hellfire Bay in Cape Le Grand National Park (ANIC Castniidae database; Atlas of Living Australia website) (Figure 25).

\section{LARVAL FOOD PLANT}

The larval food plants are Coast Sword-sedge Lepidosperma gladiatum Labill and Four-sided Sedge Lepidosperma tetraquetrum Nees.

\section{HABITAT}

Synemon directa occurs in a range of habitats. Along the west and south coasts the species frequents coastal dunes and wetland areas, where L. gladiatum is common. Further inland from Perth, it is found in Jarrah (Eucalyptus marginata) and Marri (Corymbia calophylla) forest, and alongside small freshwater streams on the Darling Scarp where Lepidosperma tetraquetrum is often common.

\section{BEHAVIOUR AND FLIGHT PERIOD}

In coastal sites and along streams on the Darling Scarp, adults are generally found in the vicinity of the tall sedges on which they breed. They are most active in the middle of the day, between 11:00 and 15:00 WST. Mass emergences occur occasionally in the Jarrah forests east and south of Perth (A.A.E. Williams, personal observation, January 2012). At such times the sun-moths disperse widely and may be seen flying along forest tracks, or congregating in the vicinity of exposed granite outcrops in the forest. Adults sometimes 
fly several kilometres from their breeding habitat (E.D. Edwards, personal communication, 2013). Synemon directa is known to feed readily on flowers; a female was observed and photographed feeding on the flowers of Hakea ruscifolia on the Darling Scarp east of Perth (Jean Hort, personal observation, 2008), and another was observed feeding on Eucalyptus patens flowers along a stream near Mundaring Weir (A.A.E. Williams, personal observation, 2016). The peak flying time is December to January, with occasional records in November and in late February to early March.
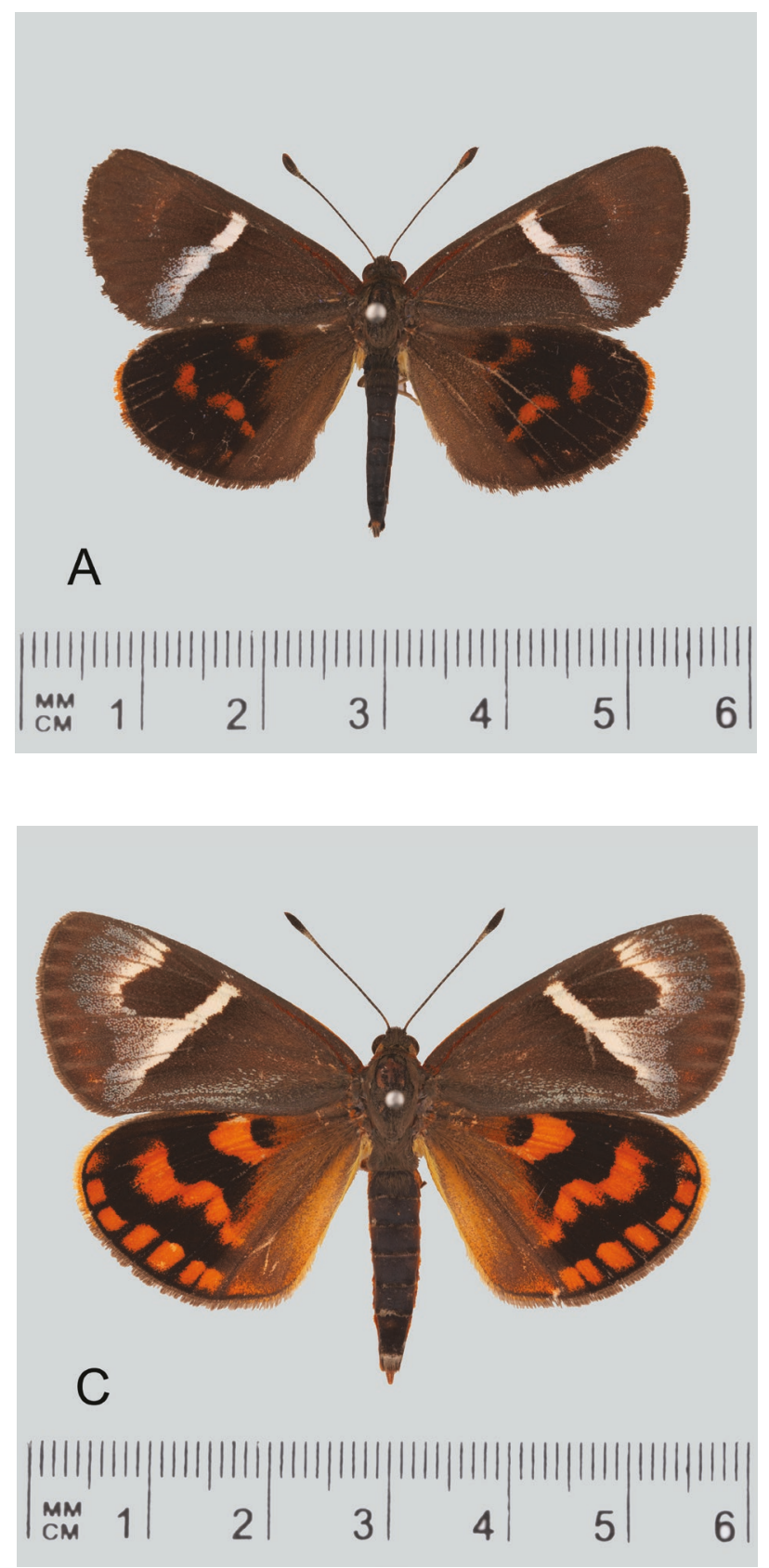

\section{CONSERVATION STATUS}

Not threatened. Synemon directa is locally common along watercourses and moist areas where one or both of its larval food plant sedges, L. gladiatum and $L$. tetraquetrum, are present. This taxon is well represented in the conservation estate and State forest. There are 40 historical and 20 recent records.

\section{HISTORICAL RECORDS}

Australia, location and date not recorded, collector unknown (in HEC Oxford); King George Sound, $35^{\circ}$ $03^{\prime} 00^{\prime \prime} \mathrm{S}, 117^{\circ} 58^{\prime} 00^{\prime \prime} \mathrm{E}$, date not recorded, collector
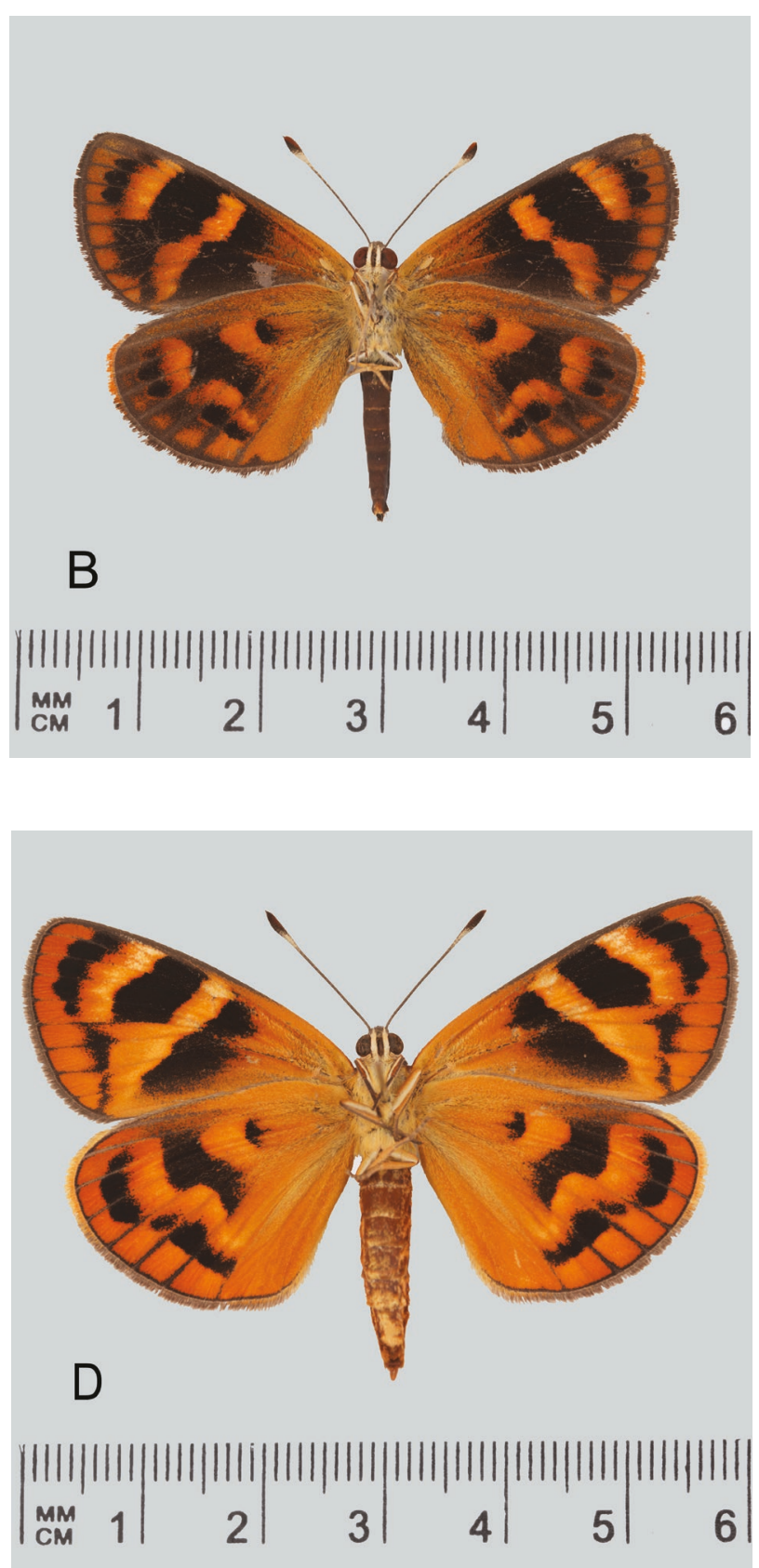

FIGURE 24 Synemon directa. A, ô Dorsal; B, ô Ventral (C2802) Western Australia, Hoffman's Mill (WAM); C, 9 Dorsal; D, o Ventral (C2925) Western Australia, Capel (WAM). (Photos: Brian Hanich, Western Australian Museum.) 


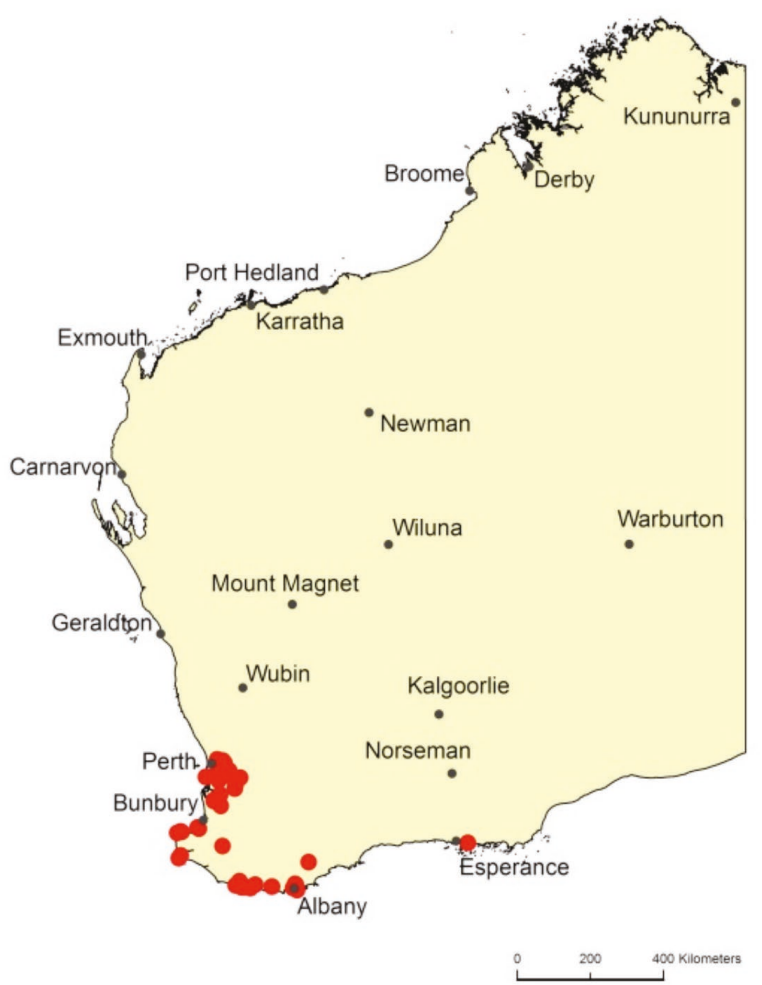

FIGURE $25 \quad$ Map of Western Australia showing distribution of Synemon directa.

unknown; Margaret River District, $33^{\circ} 58^{\prime} 00^{\prime \prime} \mathrm{S}, 115^{\circ} 03^{\prime}$ $00^{\prime \prime} \mathrm{E}$, date not recorded, collector unknown; Waroona, $32^{\circ} 51^{\prime} 00^{\prime \prime ~ S, ~} 115^{\circ} 55^{\prime} 00^{\prime \prime}$ E, 28 Dec 1904, G.F. Berthoud; Hamel, 32॰ 52' 00" S, $115^{\circ} 55^{\prime}$ 00" E, 01 Jan 1907, G.F. Berthoud; Wilsons Inlet (Denmark), 34 58' 00" S, $117^{\circ}$ 21' 00" E, 27 Dec 1912, S.W. Jackson (AM); Bow River, $34^{\circ} 55^{\prime} 00^{\prime \prime} \mathrm{S}, 116^{\circ} 56^{\prime} 00^{\prime \prime} \mathrm{E}, 31$ Dec 1912, S.W. Jackson (AM); Hamel, 32 52' 00" S, $115^{\circ} 55^{\prime} 00^{\prime \prime}$ E, 14 Dec 1913, R. Illidge; Yallingup, $33^{\circ} 39^{\prime} 00^{\prime \prime} \mathrm{S}, 115^{\circ} 01^{\prime} 00^{\prime \prime} \mathrm{E}, 23$ Dec 1913, R.T. Turner; Parkerville, $31^{\circ} 53^{\prime} 00^{\prime \prime} \mathrm{S}, 116^{\circ} 08^{\prime}$ 00" E, 08 Jan 1926, W.B. Barnard; Waroona, 32 51' 00" S, $115^{\circ} 55^{\prime} 00^{\prime \prime}$ E, 14 Jan 1926, W.B. Barnard; Armadale, 32॰ 09' 00" S, 116 00' 00" E, 07 Jan 1936, K.R Norris; Denmark (general), $34^{\circ} 58^{\prime} 00^{\prime \prime} \mathrm{S}, 117^{\circ} 21^{\prime} 00^{\prime \prime} \mathrm{E}, 11 \mathrm{Dec}$ 1962, F.E. Parsons; Deepdene (Deepdene Cave), 34 16' 00" S, $115^{\circ} 03^{\prime} 00^{\prime \prime}$ E, 08 Feb 1963, L.M. O'Halloran; 1 mile W of Mundaring Weir, $31^{\circ} 57^{\prime} 00^{\prime \prime} \mathrm{S}, 116^{\circ} 09^{\prime} 00^{\prime \prime} \mathrm{E}$, 06 Mar 1963, J. Dell; Deepdene, Karridale, 34 12' 00" S, $115^{\circ} 06^{\prime} 00^{\prime \prime}$ E, 17 Jan 1967, M.S. Upton; Serpentine Falls, $32^{\circ} 22^{\prime} 00^{\prime \prime} \mathrm{S}, 116^{\circ} 02^{\prime} 00^{\prime \prime} \mathrm{E}, 20$ Jan 1971, G.A. Holloway (UQ); Dwellingup (general), 32 $2^{\circ} 43^{\prime} 00^{\prime \prime} \mathrm{S}, 116^{\circ} 04^{\prime} 00^{\prime \prime}$ E, 31 Dec 1972, S.M. Wallace; Eagle Bay, Naturaliste, $32^{\circ} 01^{\prime} 00^{\prime \prime} \mathrm{S}, 115^{\circ} 27^{\prime} 00^{\prime \prime} \mathrm{E}, 15$ Jan 1974, M. Grimm (DAFC); Nornalup, Valley of the Giants, $35^{\circ} 00^{\prime} 00^{\prime \prime} \mathrm{S}$, $116^{\circ} 49^{\prime} 00^{\prime \prime}$ E, 18 Jan 1974, J.S. Womersley (SAM); 27 $\mathrm{km}$ N of Mandurah, 32 $2^{\circ} 17^{\prime} 00^{\prime \prime} \mathrm{S}, 115^{\circ} 43^{\prime} 00^{\prime \prime} \mathrm{E}, 18 \mathrm{Nov}$ 1975, K.A. Spencer (WAM); Boulder Rock, Brookton Highway, $32^{\circ} 18^{\prime} 00^{\prime \prime} \mathrm{S}, 116^{\circ} 34^{\prime} 00^{\prime \prime} \mathrm{E}, 13$ Jan 1978, K.T. Richards; Walpole, $34^{\circ} 59^{\prime} 00^{\prime \prime} \mathrm{S}, 116^{\circ} 44^{\prime}$ 00" E, 24 Jan 1979, R.P. McMillan (WAM); Bluff Knoll, Stirling Range National Park, 34 22' 00" S, $118^{\circ} 15^{\prime} 00^{\prime \prime}$ E, 31 Dec 1985 ,
M.J. Lewis; $15 \mathrm{~km}$ NNE of Albany, $34^{\circ} 55^{\prime} 00^{\prime \prime} \mathrm{S}, 117^{\circ}$ 56' 00" E, 16 Jan 1987, G. Daniels, A. Daniels (UQ); Hellfire Bay, Cape Le Grand National Park, 34 01' 00" S, $122^{\circ} 10^{\prime}$ 00" E, 20 Dec 1989, R.P. Field; Broke Inlet, $34^{\circ} 56^{\prime} 00^{\prime \prime} \mathrm{S}, 116^{\circ} 27^{\prime} 00^{\prime \prime}$ E, 16 Jan 1991, M.S. Moulds and B.J. Moulds; $1 \mathrm{~km}$ N of Crystal Springs, $34^{\circ} 59^{\prime} 00^{\prime \prime}$ S, $116^{\circ} 36^{\prime} 00^{\prime \prime}$ E, 05 Jan 1993, E.D. Edwards and E.S. Nielsen; Hooper Road, Albany, 34 58' 00" S, $117^{\circ} 55^{\prime}$ 00" E, 21 Jan 1993, E.D. Edwards; 7 km W of Walpole, $34^{\circ} 59^{\prime} 00^{\prime \prime} \mathrm{S}, 116^{\circ} 39^{\prime} 00^{\prime \prime}$ E, 25 Jan 1993, E.D. Edwards and E.S. Nielsen; Swan River, $31^{\circ} 51^{\prime} 00^{\prime \prime}$ S, $116^{\circ} 00^{\prime} 00^{\prime \prime}$ E, date not recorded, L.J. Newman; Albany, $35^{\circ} 00^{\prime} 00^{\prime \prime}$ S, $117^{\circ} 52^{\prime} 00^{\prime \prime}$ E, date not recorded, L.J. Newman; Deep River, $34^{\circ} 50^{\prime} 00^{\prime \prime} \mathrm{S}, 116^{\circ} 33^{\prime} 00^{\prime \prime} \mathrm{E}$, date not recorded, F.L. Whitlock; Nornalup, $35^{\circ} 00^{\prime} 00^{\prime \prime} \mathrm{S}, 116^{\circ} 49^{\prime} 00^{\prime \prime} \mathrm{E}$, date not recorded, P.N Forte (DAFC); Bridgetown, $33^{\circ}$ $58^{\prime} 12^{\prime \prime} \mathrm{S}, 116^{\circ} 07^{\prime} 48^{\prime \prime} \mathrm{E}$, date not recorded, H. Bracken; Pickering Brook, $32^{\circ} 02^{\prime} 00^{\prime \prime} \mathrm{S}, 116^{\circ} 06^{\prime} 00^{\prime \prime} \mathrm{E}$, date not recorded, R.C. Owen (WAM); Dunsborough, $33^{\circ} 37^{\prime} 00^{\prime \prime}$ S, $115^{\circ} 06^{\prime} 00^{\prime \prime} \mathrm{E}$, date not recorded, R.W. Hay; Manjedal Brook Scout Camp, 32 $17^{\circ}$ 08" S, $116^{\circ} 02^{\prime} 33^{\prime \prime}$ E, 31 Dec 1993, M.R. Williams; Manjedal Brook Scout Camp, $32^{\circ}$ 17' 08" S, 116 02' 33" E, 20 Jan 1994, M.R. Williams; Capel Beach, 33.54999 $\mathrm{S}, 115.550003^{\circ} \mathrm{E}, 30$ Dec 1995, A.A.E. Williams.

\section{RECENT RECORDS}

$10 \mathrm{~km} \mathrm{~W}$ of Christmas Tree Well, $32^{\circ} 12^{\prime} 41^{\prime \prime} \mathrm{S}, 116^{\circ} 19^{\prime}$ 06" E, 09 Jan 2009, P. Hutchinson; Manjedal Brook, $32^{\circ}$ $17^{\prime} 17^{\prime \prime}$ S, $116^{\circ} 02^{\prime}$ 13" E, 08 Jan 2010, A.A.E. Williams; Walpole, Crystal Springs, 34 57' 18" S, $116^{\circ} 36^{\prime} 13^{\prime \prime}$ E, 24 Nov 2010, A.A.E. Williams; Brady State Forest, $32^{\circ}$ 16' 05" S, $116^{\circ} 21^{\prime} 03^{\prime \prime}$ E, 06 Jan 2011, F. Hort and J. Hort; $11 \mathrm{~km} \mathrm{~N}$ of North Bannister, 32 28' 56" S, $116^{\circ} 27^{\prime} 09^{\prime \prime}$ E, 08 Jan 2011, F. Hort and J. Hort; 2 km NW of North Bannister, 32 33' 50" S, $116^{\circ} 25^{\prime}$ 50" E, 10 Jan 2011, F. Hort and J. Hort; Lesley State Forest, Kinsella Road, $32^{\circ} 10^{\prime} 53^{\prime \prime} \mathrm{S}, 116^{\circ} 11^{\prime} 27^{\prime \prime}$ E, 26 Jan 2011, F. Hort and J. Hort; Mount Dale, Bibbulmun Track, 32 07' 46" S, $116^{\circ}$ $17^{\prime} 23^{\prime \prime}$ E, 02 Jan 2012, A.A.E. Williams; Omeo Road, SW of Mount Dale, 32 09' 03" S, $116^{\circ} 17^{\prime} 14^{\prime \prime}$ E, 10 Jan 2012, A.A.E. Williams; Mount Dale, near summit, $32^{\circ}$ 07' 23" S, $116^{\circ} 17^{\prime}$ 37" E, 13 Jan 2012, A.A.E. Williams; Brookton Highway, State Forest, 32 ${ }^{\circ} 11^{\prime} 09^{\prime \prime}$ S, $116^{\circ} 15^{\prime}$ 50" E, 18 Jan 2012, F. Hort and J. Hort; Nanga Brook, NE of Waroona, 32 49' 40" S, $115^{\circ} 57^{\prime}$ 34" E, 26 Jan 2012, A.A.E. Williams; Hoffman's Mill, $32^{\circ} 59^{\prime} 15^{\prime \prime} \mathrm{S}, 116^{\circ} 05^{\prime}$ 21" E, 12 Jan 2013, A.A.E. Williams; Dunsborough, $33^{\circ}$ $37^{\prime} 33^{\prime \prime}$ S, $115^{\circ} 07^{\prime}$ 39" E, 26 Jan 2013, A.A.E. Williams; Capel, Peppermint Grove, $33^{\circ} 30^{\prime}$ 58" S, $115^{\circ} 31^{\prime} 05^{\prime \prime}$ E, 28 Jan 2013, A.A.E. Williams; Perth, Gosnells Regional Park, $32^{\circ} 05^{\prime} 20^{\prime \prime} \mathrm{S}, 116^{\circ} 02^{\prime} 08^{\prime \prime}$ E, 14 Jan 2015, A.A.E. Williams; Mundaring Weir Road, Mundaring, 31 $56^{\circ} 18^{\prime \prime}$ S, $116^{\circ} 10^{\prime}$ 53" E, 11 Dec 2015, A.A.E. Williams; Fred Jacoby Forest Park, Mundaring, 31 ${ }^{\circ} 56^{\prime} 49^{\prime \prime}$ S, $116^{\circ} 10^{\prime} 33^{\prime \prime}$ E, 17 Dec 2015, A.A.E. Williams; Ashendon Road, SSE of Mundaring, 32 00' 51" S, $116^{\circ} 11^{\prime} 29^{\prime \prime}$ E, 02 Jan 2016 , A.A.E. Williams; South Ledge Road, Mundaring, $31^{\circ} 57^{\prime}$ 51" S, $116^{\circ} 09^{\prime} 10^{\prime \prime}$ E, 05 Jan 2016, A.A.E. Williams. 


\section{Synemon sp. 'Victoria Rock' (Goldfields Sun-moth)}

Figure 26

\section{BRIEF DESCRIPTION}

Synemon sp. 'Victoria Rock' is a large, distinctive sunmoth. In both sexes the upper side of the forewing is a uniform pale grey-brown, with two oblique broad white cross bands. The basal area and broad inner margin on the upper side of the hind wing is pale grey-brown. The remaining portion of the hind wing is bright orangebrown, with two contrasting black bands. The central median black band has a very distinctive curved-angular shape, while the outer subterminal band is relatively straight. In females the orange-brown terminal margin is segmented by a series of narrow black radiating vein lines. Males are less clearly patterned along the outer margin of the hind wing. In very fresh specimens the scale fringe on the edge of the wings is grey and white. In both sexes, the basal area on the underside of both wings is whitish-grey, merging to yellowish-orange and then orange along the outer margin. The underside of the forewing has two distinct pale bands, which are in the same position as the upperside white bands. These pale

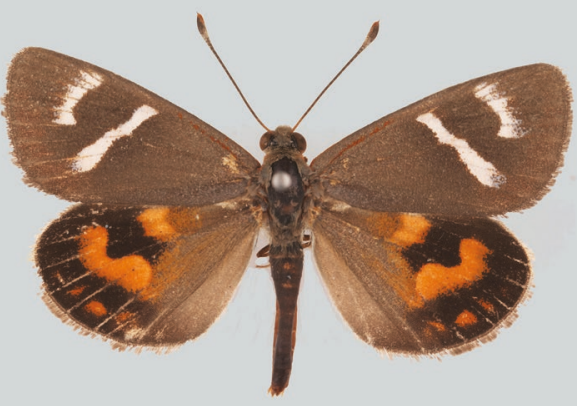

A

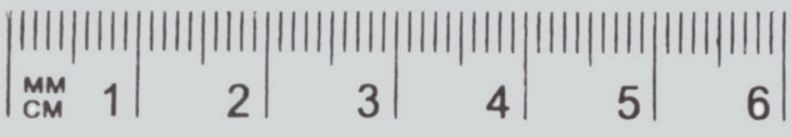

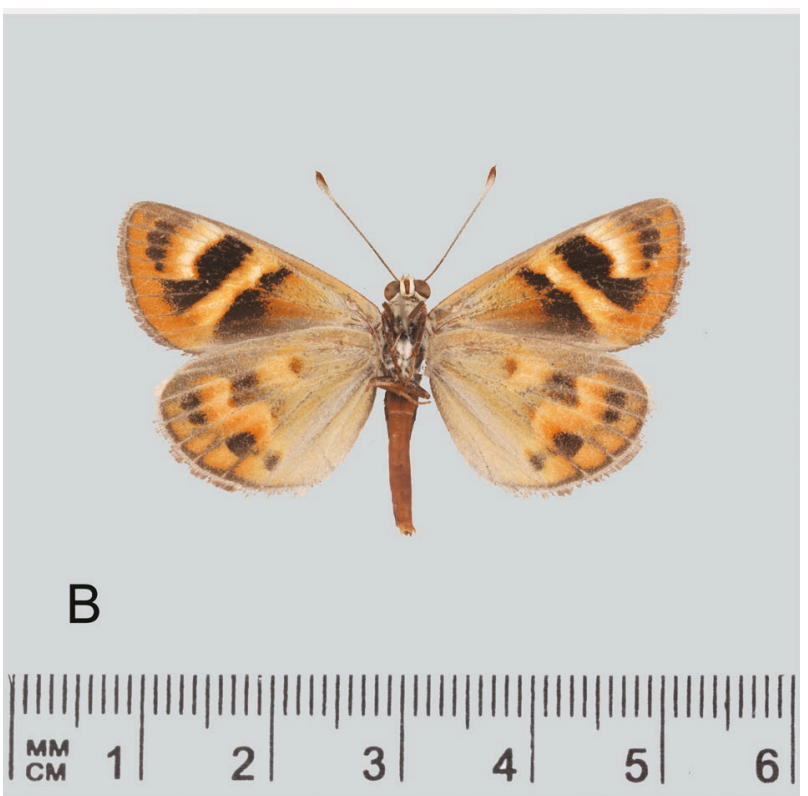

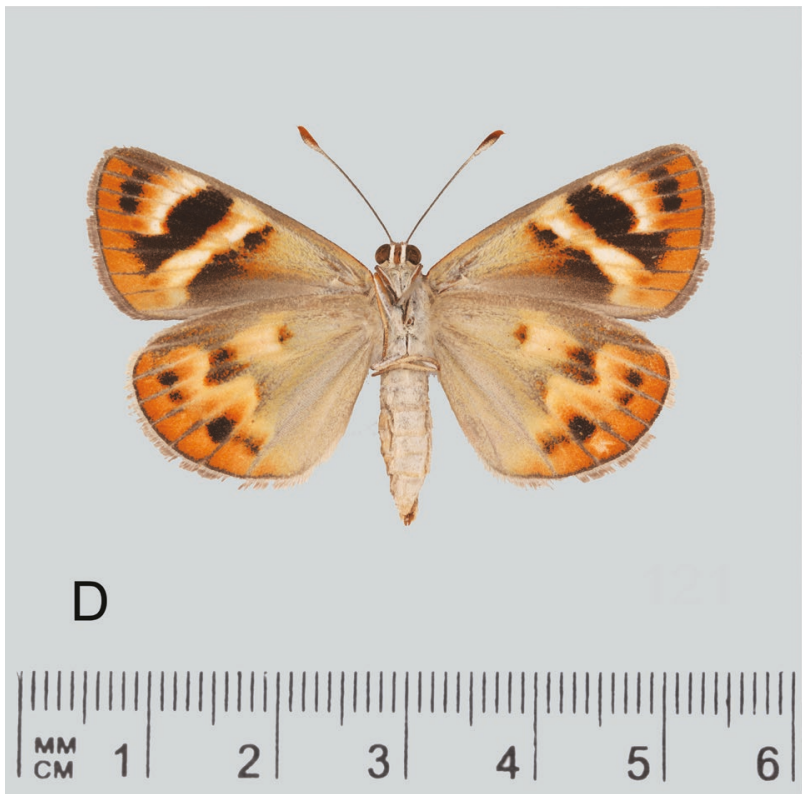

FIGURE 26 Synemon sp. 'Victoria Rock'. A, ô Dorsal; B, ổ Ventral (C2303) Western Australia, Boondi Rock (WAM); C, o Dorsal; D, o Ventral (C2307) Western Australia, Boondi Rock (WAM). (Photos: Brian Hanich, Western Australian Museum.) 


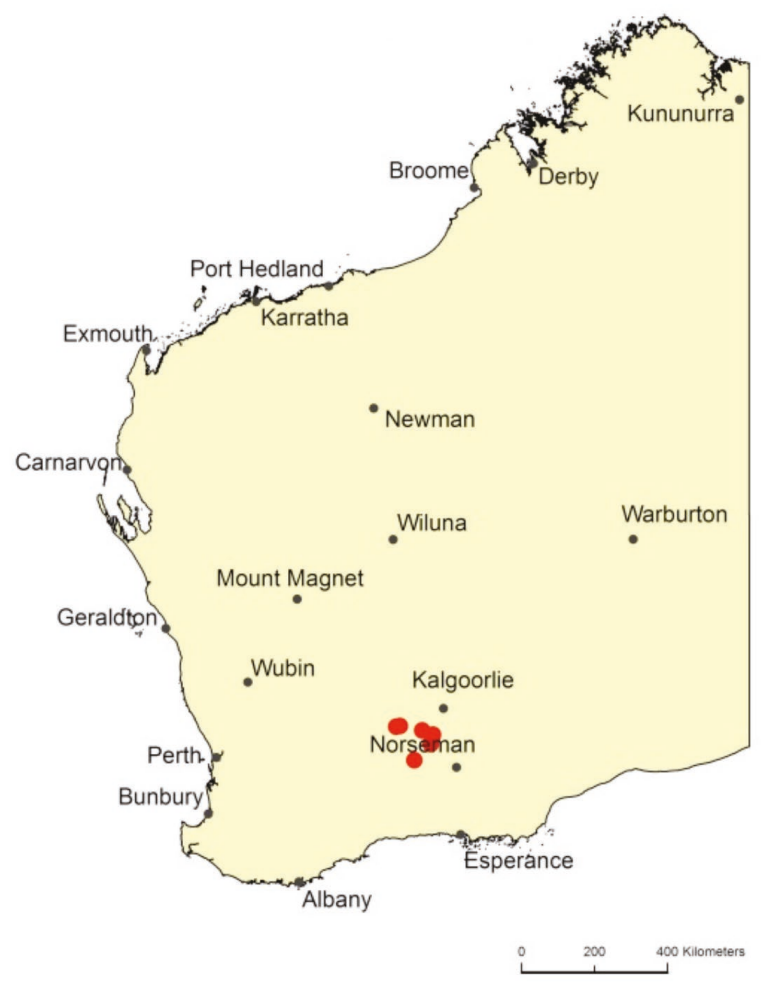

FIGURE 27 Map of Western Australia showing distribution of Synemon sp. 'Victoria Rock'.

underside bands are broadly edged in black. The hind wing is less heavily marked. This species superficially resembles $S$. directa.

\section{DISTRIBUTION}

This species is confined to the inland Goldfields and Great Western Woodlands of Western Australia. It was initially recorded from Queen Victoria Rock and Burra Rock near Coolgardie (ANIC Castniidae database). More recently, populations have been located at several new sites: Boondi Rock and Boorabbin Rock north of the Great Eastern Highway, an unnamed rock $8 \mathrm{~km}$ west-north-west of Caves Hill, a large unnamed rock 5 $\mathrm{km}$ south of Burra Rock, and McDermid Rock alongside the Hyden-Norseman Road (Figure 27).

\section{LARVAL FOOD PLANT}

The larval food plant is a large tall shiny-leafed sedge, Lepidosperma drummondii Benth. Mature larvae have been found in tunnels inside the leaf bases, and pupae within vertical tubular shelters at the base of the leaves.

\section{HABITAT}

Synemon sp. 'Victoria Rock' is found in the vicinity of granite outcrops where its large larval food plant sedge is well established. These sedges generally grow at the base of the rocks, or along natural channels in the rock where soil has accumulated and a seasonal water run off is available.

\section{BEHAVIOUR AND FLIGHT PERIOD}

This is a large, fast flying sun-moth. Adults are active in hot sunny conditions in the vicinity of the larval food plant sedges. Males may be seen flying over the rocks or alongside belts of sedges in search of freshly emerged females. The flight period is from February to March, but the emergence times are unpredictable, and may vary considerably from year to year. On 15 February 2015 the species was common on a granite rock $8 \mathrm{~km}$ west-north-west of Caves Hill. On the same day the following year, in apparently ideal conditions, the sunmoths were absent. This indicates that there must be factors which influence emergence about which we know very little.

\section{CONSERVATION STATUS}

Data deficient. At present this taxon is known from a few granite outcrops in the Goldfields and Great Western Woodlands of Western Australia. Further exploration of other rocky outcrops in the region is needed to establish its distributional boundaries. There are two historical and five recent records.

\section{HISTORICAL RECORDS}

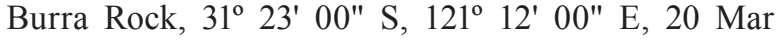
1988, A.J. Graham; Queen Victoria Rock, 31 ${ }^{\circ} 17^{\prime} 32^{\prime \prime}$ S, $120^{\circ} 55^{\prime} 32^{\prime \prime}$ E, 12 Mar 1996, E.D. Edwards and E.S. Nielsen.

\section{RECENT RECORDS}

Boondi Rock, Coolgardie, $31^{\circ} 10^{\prime} 41^{\prime \prime} \mathrm{S}, 120^{\circ} 22^{\prime} 56^{\prime \prime}$ E, 21 Feb 2012, A.A.E. Williams; McDermid Rock, $32^{\circ} 01^{\prime} 16^{\prime \prime} \mathrm{S}, 120^{\circ} 44^{\prime} 21^{\prime \prime}$ E, 13 Feb 2015, A.A.E. Williams; Granite Rock, $8 \mathrm{~km}$ WNW Caves Hill, $31^{\circ}$ 37' 32" S, 1210 08' 41" E, 15 Feb 2015, A.A.E. Williams; Boorabbin Rock, 31 $11^{\circ}$ '03" S, $120^{\circ} 17^{\prime} 15^{\prime \prime}$ E, 19 Feb 2015, A.A.E. Williams; Granite Rock, $5 \mathrm{~km} \mathrm{~S}$ of Burra Rock, 31 $26^{\circ} 22^{\prime \prime} \mathrm{S}, 121^{\circ} 11^{\prime} 19^{\prime \prime}$ E, 13 Feb 2015, A.A.E. Williams.

\section{Synemon magnifica species group \\ Synemon notha Westwood 1877 (Anzac Sun-moth)}

Figure 28

\section{BRIEF DESCRIPTION}

This small sun-moth with rounded wings has a wingspan of approximately $30 \mathrm{~mm}$. The upper side of the forewing is grey to grey-brown, delicately patterned with blackish markings. The hind wing base colour is dark grey-brown, with a prominent submedian discal redorange spot near the costa, and a broad central postmedian red-orange band. The grey-brown outer border encloses a series of small, orange spots. The underside is orange to orange-brown, with bold blackish markings and a few 
small white spots. The outer edge of both wings is lined with a series of orange-white spots. The common name 'Anzac Sun-moth' commemorates the Australian and New Zealand ANZAC troops who departed from King George Sound for Gallipoli in late 1914.

\section{DISTRIBUTION}

Synemon notha is a Western Australian endemic. It has a predominantly south coastal distribution, having been recorded from Kalgup near Busselton east to Albany and Cape Riche. It has also been recorded inland at Stirling Range National Park, Mordetta Nature
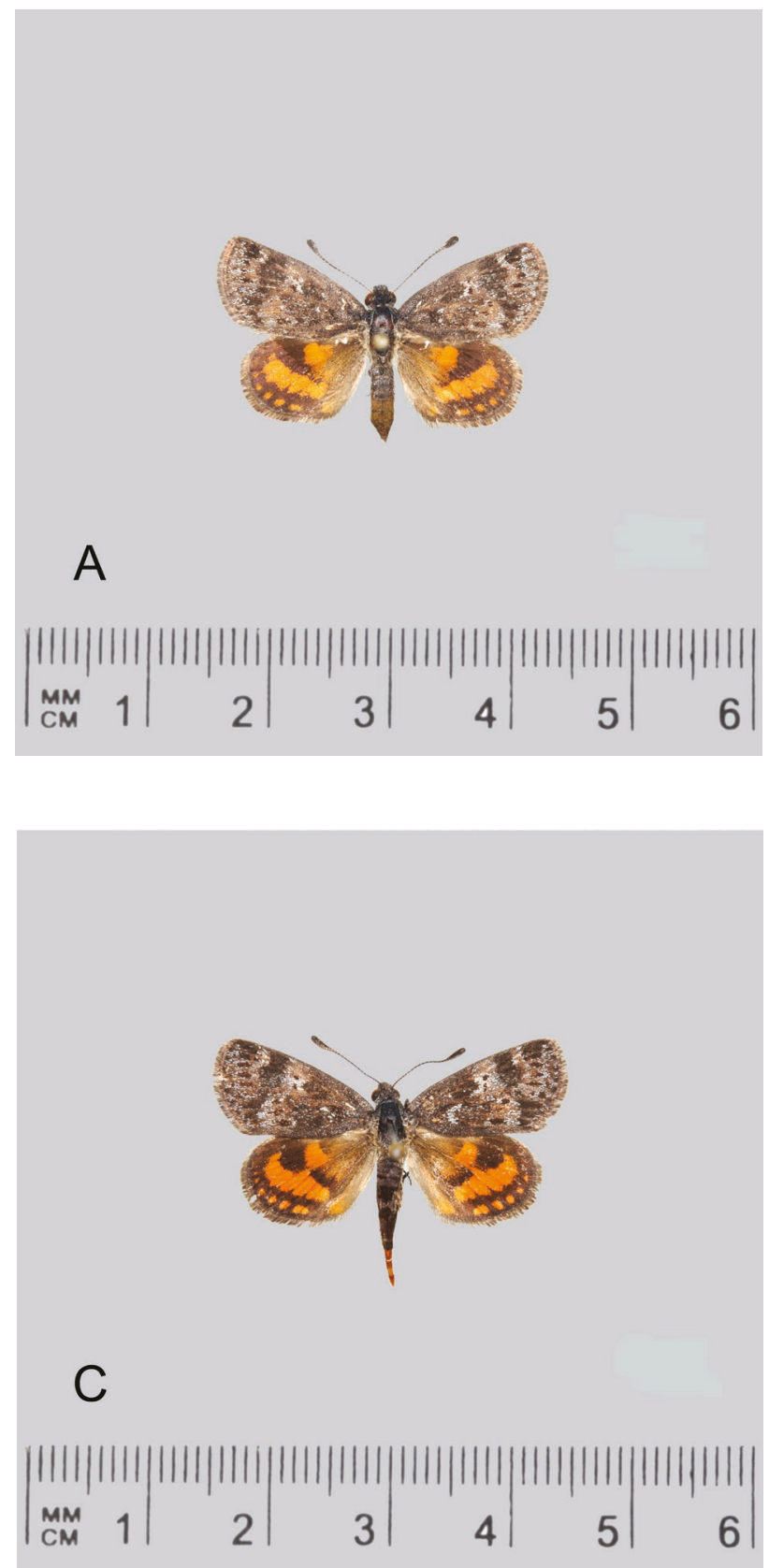

Reserve, and $8 \mathrm{~km}$ east of Pingaring (ANIC Castniidae database). The most recent record is from the Hooper Road Bushland near Albany (Williams and Williams 2016b) (Figure 29).

\section{LARVAL FOOD PLANT}

The larval food plant has not been recorded.

\section{HABITAT}

At Hooper Road $S$. notha is found in the ecotone between winter-wet, species rich sedgeland and mixed Eucalyptus and Allocasuarina forest. In Stirling Range
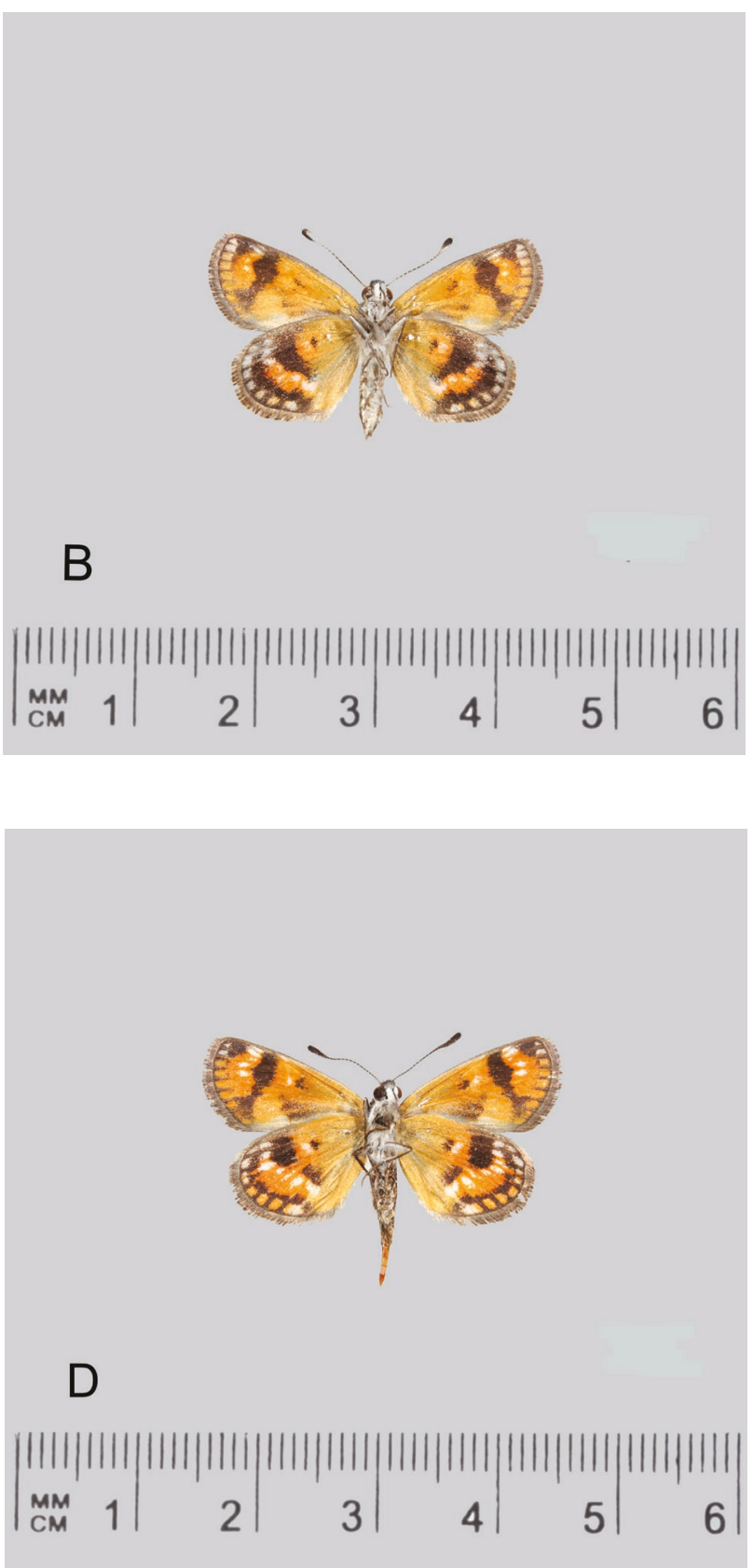

FIGURE 28 Synemon notha. A, ô Dorsal; B, ð̃ Ventral (ANIC31014776) Western Australia, Hooper Road, Albany (ANIC); C, o Dorsal; D, o Ventral (ANIC31014778)Western Australia, Hooper Road, Albany (ANIC). (Photos: You Ning Su, CSIRO, Canberra.) 


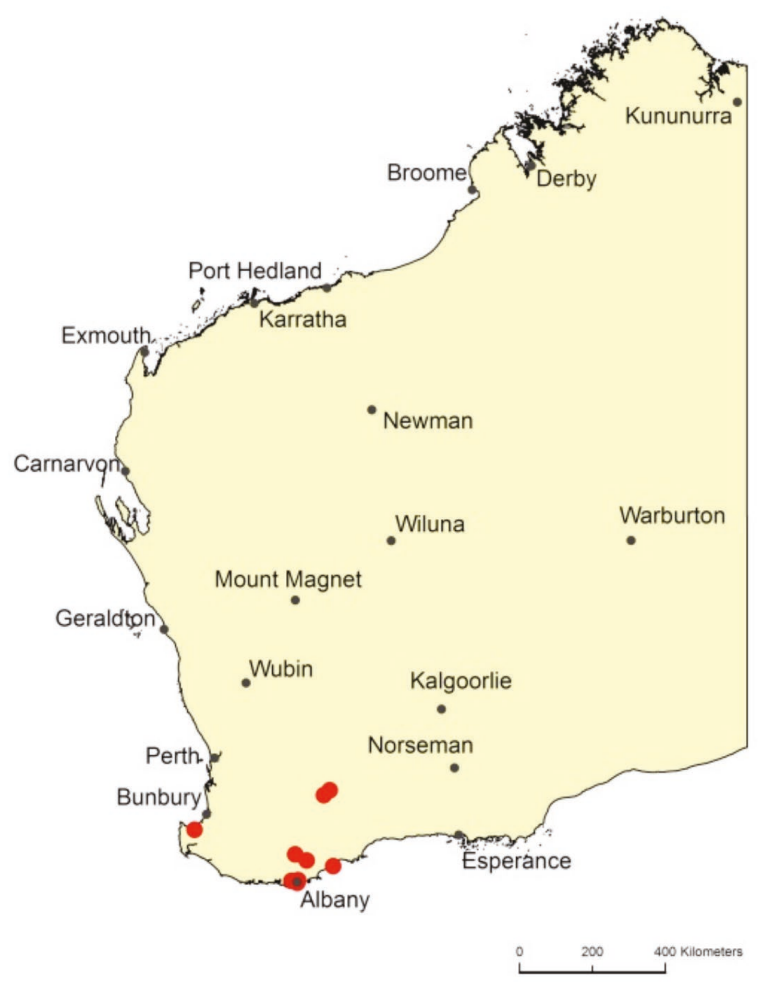

FIGURE 29 Map of Western Australia showing distribution of Synemon notha.

National Park, specimens have been collected along roadside drainage ditches on the low heathland flats south of the range, and in an old gravel extraction site on the northern boundary of the national park.

\section{BEHAVIOUR AND FLIGHT PERIOD}

This species is only active in sunny conditions between 10:00 and 15:00 WST. Adults fly very close to the ground. At inland localities the species flies in November and December. On the coast near Albany it has been recorded mainly in January, though there are two historical records in late February and early March.

\section{CONSERVATION STATUS}

Data deficient. Targeted searches for S. notha in recent years have failed to locate this iconic species, which suggests it may now be very uncommon. In Stirling Range National Park it has been recorded on only two occasions. The winter-wet locality at Hooper Road near Albany has suffered from inappropriate use by off-road vehicles. Searches in nearby Gull Rock Nature Reserve, Two Peoples Bay Nature Reserve and near Walpole have so far failed to locate any further populations. The sun-moth appears to be extinct at its historical site of King George Sound. There are 13 historical and one recent records.

\section{HISTORICAL RECORDS}

Albany, King George Sound, $35^{\circ} 00^{\prime} 00^{\prime \prime} \mathrm{S}, 117^{\circ}$ $52^{\prime} 00^{\prime \prime} \mathrm{E}$, date not recorded, collector unknown (MM); Albany, 35 00' 00" S, $117^{\circ} 52^{\prime} 00^{\prime \prime} \mathrm{E}$, date not recorded, collector unknown (HEC); Cape Riche, $34^{\circ} 37^{\prime} 00^{\prime \prime}$ S, $118^{\circ} 47^{\prime} 00^{\prime \prime}$ E, January 1913, collector unknown (HEC); Albany, 35 00' 00" S, $117^{\circ} 52^{\prime} 00^{\prime \prime}$ E, 02 Mar 1926, W.B. Barnard (QM); Kalgup, E of Busselton, 34 44' 00" S, $115^{\circ} 23^{\prime}$ 00" E, 23 Feb 1928, J.K. Ewers; Albany, $35^{\circ} 00^{\prime} 00^{\prime \prime} \mathrm{S}, 117^{\circ} 52^{\prime} 00^{\prime \prime}$ E, 08 Jan 1935, K.R. Norris; 5 miles $E$ of Pingaring, $32^{\circ}$ $45^{\prime} 00^{\prime \prime}$ S, $118^{\circ} 42^{\prime}$ 00" E, 12 Nov 1978, M. Powell; Mordetta, 32 $52^{\prime}$ 00" S, $118^{\circ} 33^{\prime} 00^{\prime \prime}$ E, 12 Nov 1978 , M. Golding; $14 \mathrm{~km} \mathrm{~W}$ of Albany, $34^{\circ} 59^{\prime} 00^{\prime \prime} \mathrm{S}, 117^{\circ} 45^{\prime}$ 00" E, 08 Jan 1986, G. Daniels and A. Daniels (QM); Albany, Hooper Road, 34 58' 00" S, $117^{\circ} 55^{\prime} 00^{\prime \prime}$ E, 18 Jan 1993, E.D. Edwards; Albany, Mount Adelaide, $35^{\circ}$ 02' 00" S, $117^{\circ}$ 54' 00" E, 22 Jan 1993, E.D. Edwards; Stirling Range National Park, $34^{\circ} 19^{\prime} 43^{\prime \prime} \mathrm{S}, 117^{\circ} 50^{\prime}$ 32" E, 04 Nov 1997, A.A.E. Williams; Stirling Range

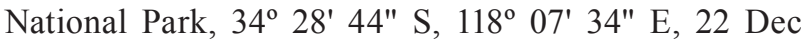
1997, A.A.E. Williams.

\section{RECENT RECORDS}

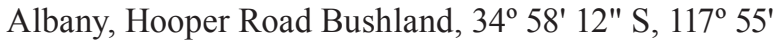
11" E, 23 Jan 2010, A.A.E. Williams.

\section{Synemon sp. 'Moirs Rock' (Royal Sun-moth)}

Figure 30

\section{BRIEF DESCRIPTION}

Synemon sp. 'Moirs Rock' is a very large sun-moth. In males the wingspan varies from 45 to $50 \mathrm{~mm}$, while females may sometimes have wingspans over $60 \mathrm{~mm}$. The upper side of their elongate forewings is dark grey, with or without faint blackish or whitish markings. The upper surface of the hind wing is blackish, with bold orange-red markings. The underside is variably patterned with orange and grey-black markings, often flecked with small white spots. Interestingly, specimens from Kukerin, Nyabing and Peak Charles National Park are noticeably larger than those collected elsewhere. This may simply reflect the very large sedge used as the larval food plant at these localities.

\section{DISTRIBUTION}

This sun-moth has a wide, though disjunct, distribution across south-western Western Australia. The first specimen was collected in the Murchison district during the Elder Expedition in 1892. A precise locality was not recorded for this northernmost record, so it has not been plotted on our species distribution map. Since then $S$. sp. 'Moirs Rock' has only been 
found further south: from the Darling Scarp and forest sites inland of Perth, from the Wheatbelt near Southern Cross, from Kukerin bushland and Nyabing bushland, and further east from Peak Charles National Park, Moirs Rock, and Jimberlana Hill near Norseman (Figure 31).

\section{LARVAL FOOD PLANT}

Near Perth, the larval food plant is a large unidentified species of Lepidosperma sedge with viscous leaf bases. In the central and southern Wheatbelt and at Peak Charles National Park, the larval food plant is Sticky Sword Sedge Lepidosperma sanguinolentum
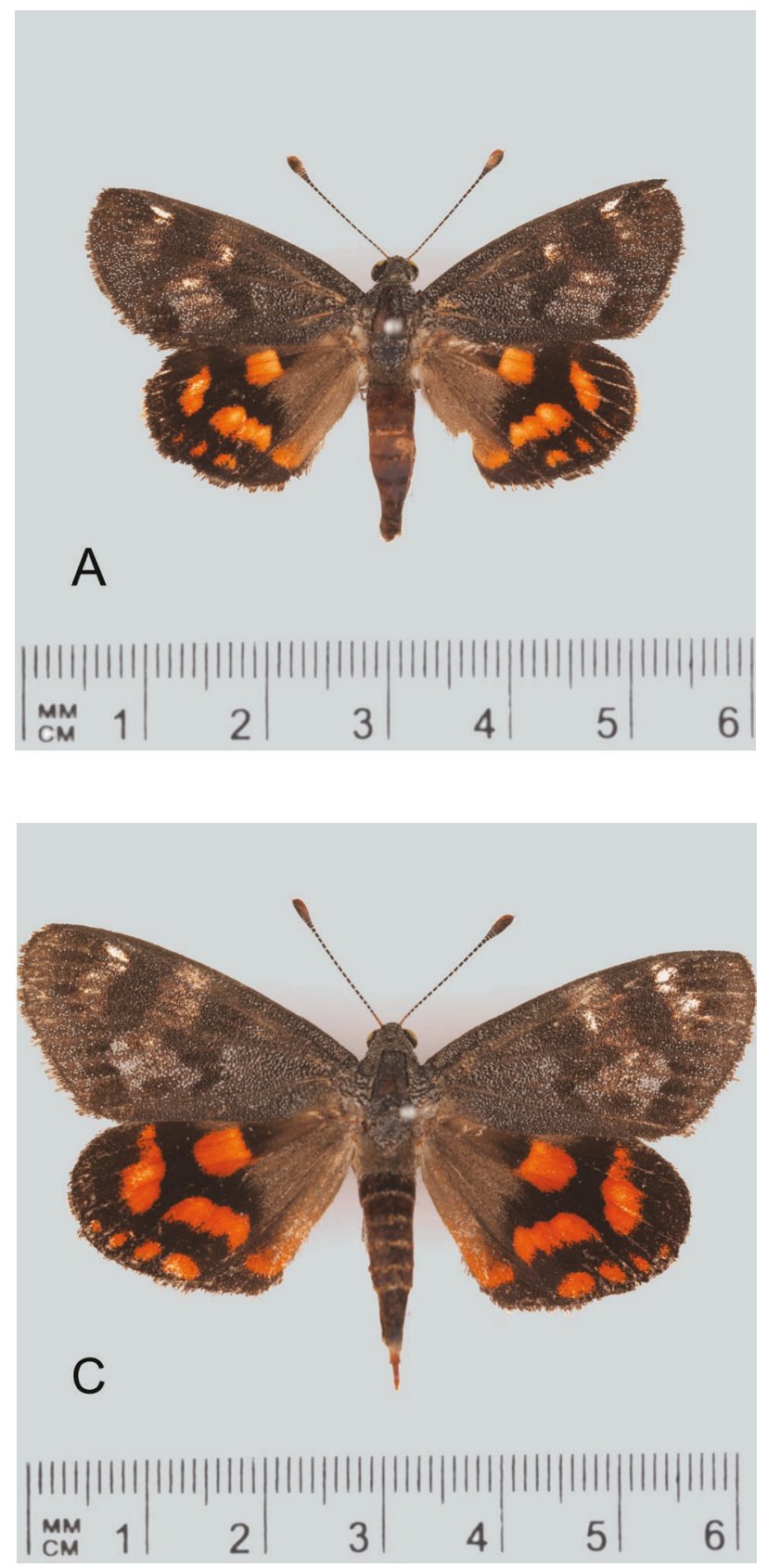

K.L Wilson, (previously Lepidosperma viscidum, Greg Keighery, personal communication, 2014). Leaves of this sedge can easily be extracted from the main plant, displaying their orange-brown, viscous leaf-bases. At Jimberlana Hill the shiny-leafed larval food plant is an undescribed species of Lepidosperma (Greg Keighery, personal communication, 2015).

\section{HABITAT}

Synemon sp. 'Moirs Rock' is found in differing habitats, dependent upon the location of the various large sedges upon which the larvae feed. In the west,
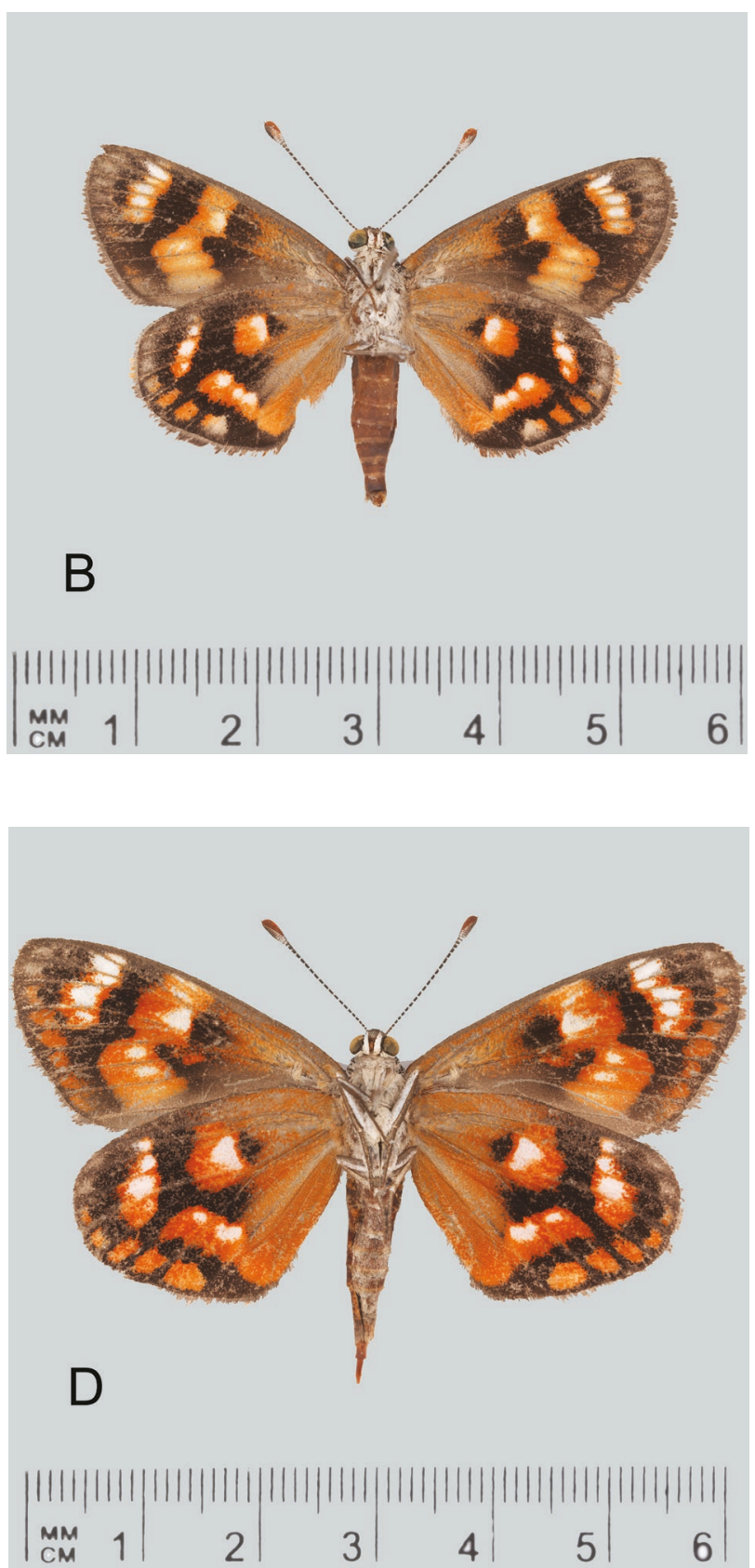

FIGURE 30 Synemon sp. 'Moirs Rock'. A, ô Dorsal; B, ô Ventral (C0285) Western Australia, Kukerin Bushland (WAM); C, o Dorsal; D, o Ventral (C0293) Western Australia, Western Australia, Kukerin Bushland (WAM). (Photos: Brian Hanich, Western Australian Museum.) 


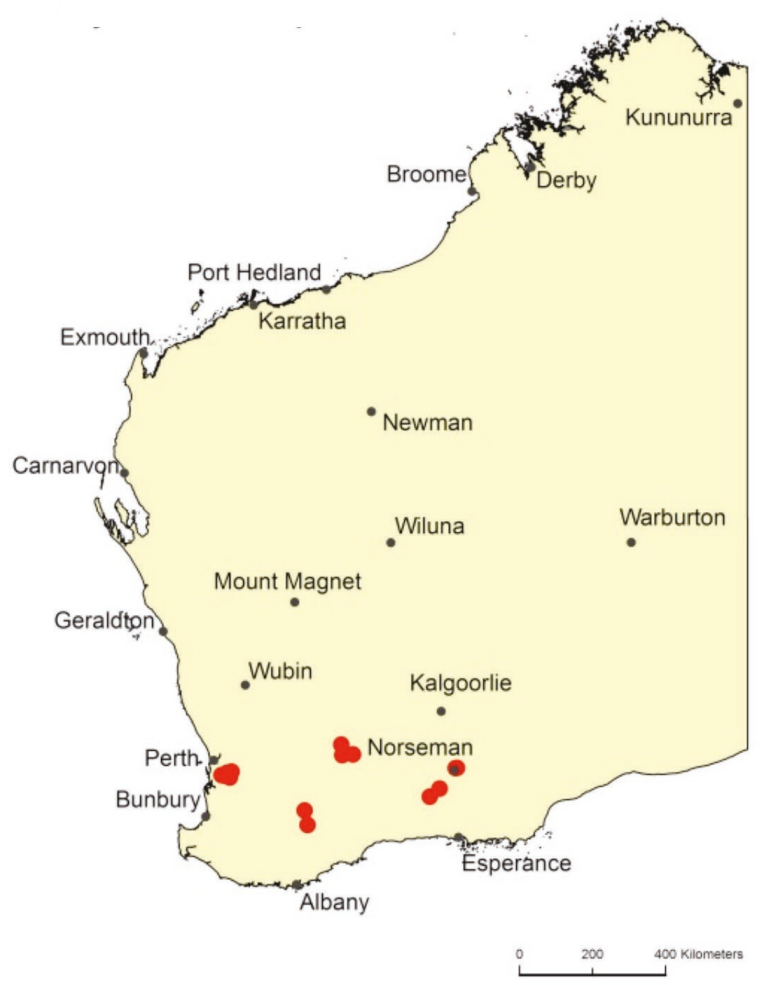

FIGURE 31 Map of Western Australia showing distribution of Synemon sp. 'Moirs Rock'.

near Perth, it is found round granite rocky outcrops, both within the Jarrah (Eucalyptus marginata) forest and on the edge of the Darling Scarp. There, the larval food plant sedges grow at the base of the rocks or in drainage channels on the rocks where sufficient soil has accumulated to support them. In the central and southern Wheatbelt and at Peak Charles National Park, the sun-moths are found in mallee woodland, where the large sedge larval food plants are usually a dominant component of the understory. At Jimberlana Hill, the larval food plant sedge is widespread and dominant on the granitic gneiss rocky hillslopes.

\section{BEHAVIOUR AND FLIGHT PERIOD}

This summer flying sun-moth is active in hot sunny conditions from mid-morning to mid-afternoon. In mallee woodland sites in the Wheatbelt, males fly openly amongst the large sedge food plants; the females are less frequently seen. On the granite outcrops of the Darling Scarp males establish territories on hilltops if the larval food plant sedge is growing nearby. On the upper slopes of Jimberlana Hill the males do not hold territories, but course widely over the large expanses of available sedge food plant. On very hot days adults rest on the cooler, shaded side of burnt upright mallee stags (E.D. Edwards, personal communication, 2013). This species flies primarily in January and has a flying period of approximately two weeks.

\section{CONSERVATION STATUS}

Data deficient. Synemon sp. 'Moirs Rock' has a wide but disjunct distribution. It may be secure, as it occurs in two national parks, but further surveys are required to confirm whether it is present in additional conservation estate. Although a known larval food plant, L. sanguinolentum, is reasonably common in the central and southern Wheatbelt, the plant's presence does not guarantee the presence of the sun-moth. There are six historical and 11 recent records.

\section{HISTORICAL RECORDS}

Murchison District, location not recorded, February 1892, R. Helms (Elder Expedition) (SAM); Moirs Rock, NW of Salmon Gums, 32 39' 00" S, $121^{\circ} 25^{\prime} 00^{\prime \prime}$ E, 01 Jan 1986, G. Daniels and A. Daniels (UQ); Norseman, Jimberlana Hill, $32^{\circ} 08^{\prime} 50^{\prime \prime}$ S, $121^{\circ} 48^{\prime} 00^{\prime \prime}$ E, 12 Jan 1993, E.D. Edwards and E.S. Nielsen; Moirs Rock, $32^{\circ}$ 39' 00" S, $121^{\circ} 25^{\prime} 00^{\prime \prime}$ E, 13 Jan 1993, E.D. Edwards, E.S. Nielsen; $60 \mathrm{~km} \mathrm{E}$ of Hyden, $32^{\circ} 25^{\prime} 00^{\prime \prime} \mathrm{S}, 119^{\circ} 28^{\prime}$ 00" E, 30 Jan 1993, E.D. Edwards, E.S. Nielsen; Mount Cook, 32 ${ }^{\circ} 15^{\prime} 36^{\prime \prime}$ S, $116^{\circ} 11^{\prime}$ 24" E, 28 Jan 1993, E.D. Edwards and E.S. Nielsen.

\section{RECENT RECORDS}

Peak Charles National Park, $33^{\circ} 51^{\prime} 11^{\prime \prime}$ S, $121^{\circ} 10^{\prime}$ 31" E, 08 Jan 2011, A.A.E. Williams; Sullivan Rock, Albany Highway, $32^{\circ} 22^{\prime} 35^{\prime \prime}$ S, $116^{\circ} 15^{\prime} 12^{\prime \prime}$ E, 15 Jan 2011, A.A.E. Williams; Nyabing Bushland, $33^{\circ} 32^{\prime} 58^{\prime \prime}$ S, $118^{\circ} 09^{\prime} 48^{\prime \prime}$ E, 17 Jan 2011, A.A.E. Williams; Serpentine National Park, 32 $2^{\circ} 19^{\prime} 06^{\prime \prime}$ S, $116^{\circ} 02^{\prime} 36^{\prime \prime}$ E, 02 Jan 2012, A.A.E. Williams; $6 \mathrm{~km}$ E of Jarrahdale, $32^{\circ} 20^{\prime} 06^{\prime \prime} \mathrm{S}$, $116^{\circ} 07^{\prime} 50^{\prime \prime}$ E, 09 Jan 2012, A.A.E. Williams; Blue Rock, ENE of Jarrahdale, $32^{\circ} 19^{\prime} 42^{\prime \prime} \mathrm{S}, 116^{\circ} 06^{\prime} 54^{\prime \prime}$ E, 09 Jan 2012, A.A.E. Williams; Abyssinia Rock, 32 ${ }^{\circ} 14^{\prime} 10^{\prime \prime}$ S, $116^{\circ} 17^{\prime} 36^{\prime \prime}$ E, 05 Jan 2013, A.A.E. Williams; Norseman, near Jimberlana Hill, 32 $08^{\prime} 24^{\prime \prime}$ S, $121^{\circ} 50^{\prime} 47^{\prime \prime}$ E, 07 Jan 2015, A.A.E. Williams; Dulyalbin Rock, SW Southern Cross, 31 34' 10" S, $118^{\circ} 59^{\prime} 42^{\prime \prime}$ E, 13 Jan 2016, A.A.E. Williams; Cramphorne Road, Southern Cross, $31^{\circ} 48^{\prime} 25^{\prime \prime}$ S, $119^{\circ}$ 17' 07" E, 14 Jan 2016, A.A.E. Williams; Nulla Nulla South Rd, Southern Cross, $31^{\circ} 49^{\prime} 33^{\prime \prime}$ S, $119^{\circ} 01^{\prime}$ 06" E, 27 Jan 2016, A.A.E. Williams.

\section{Synemon sp. 'Mount Dale' (Semaphore Sun-moth)}

Figure 32

\section{BRIEF DESCRIPTION}

This is a very distinctive, medium sized sun-moth, with a wingspan varying from 40 to $46 \mathrm{~mm}$. The sexes are similar, though males are usually smaller than females. The upper side of the forewing is generally dark grey with blackish markings. Most individuals have distinct median and subapical white patches near the leading edge of the forewing. Three contrasting fused pale grey postmedian patches, each with a black central 
eyespot, are located towards the dorsum on the forewing (see Figure $32 \mathrm{~A} / \mathrm{C}$ ). The ground colour on the upper hind wing is blackish with bold orange markings. On the underside the basal area of both wings is orange-brown. The remainder of the underside has a patchwork of black and dull orange markings, sparsely dotted in white. The presence of a silvery white strip along the outer dorsum of the forewing is almost always a good diagnostic character. Specimens from an isolated northern colony in Lesueur National Park, 220 km north-north-west of Perth, have much more extensive white markings on the underside of their wings.
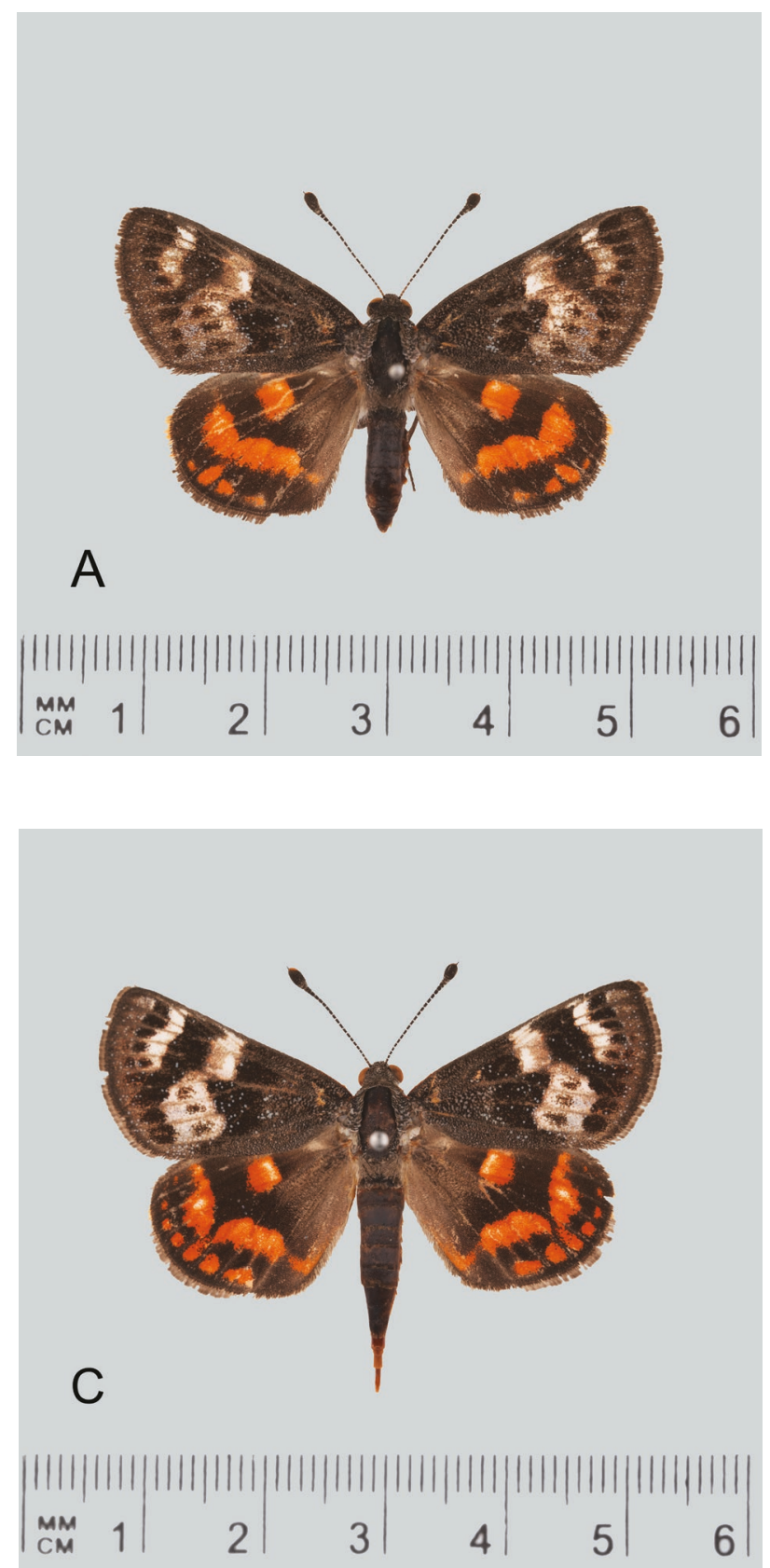

\section{DISTRIBUTION}

There are early records of $S$. sp. 'Mount Dale' from Kalamunda and Hovea on the Darling Scarp, inland at Mount Dale and north of Bannister, and nearer the coast at Yarloop (ANIC Castniidae database). There are recently recorded intermediate populations as well as confirmation of the continued presence of an isolated northern population at Mount Peron in Lesueur National Park. Although the larval food plant is common in the south-west and south coastal areas, the sun-moth has not been recorded south of Yarloop (Figure 33).
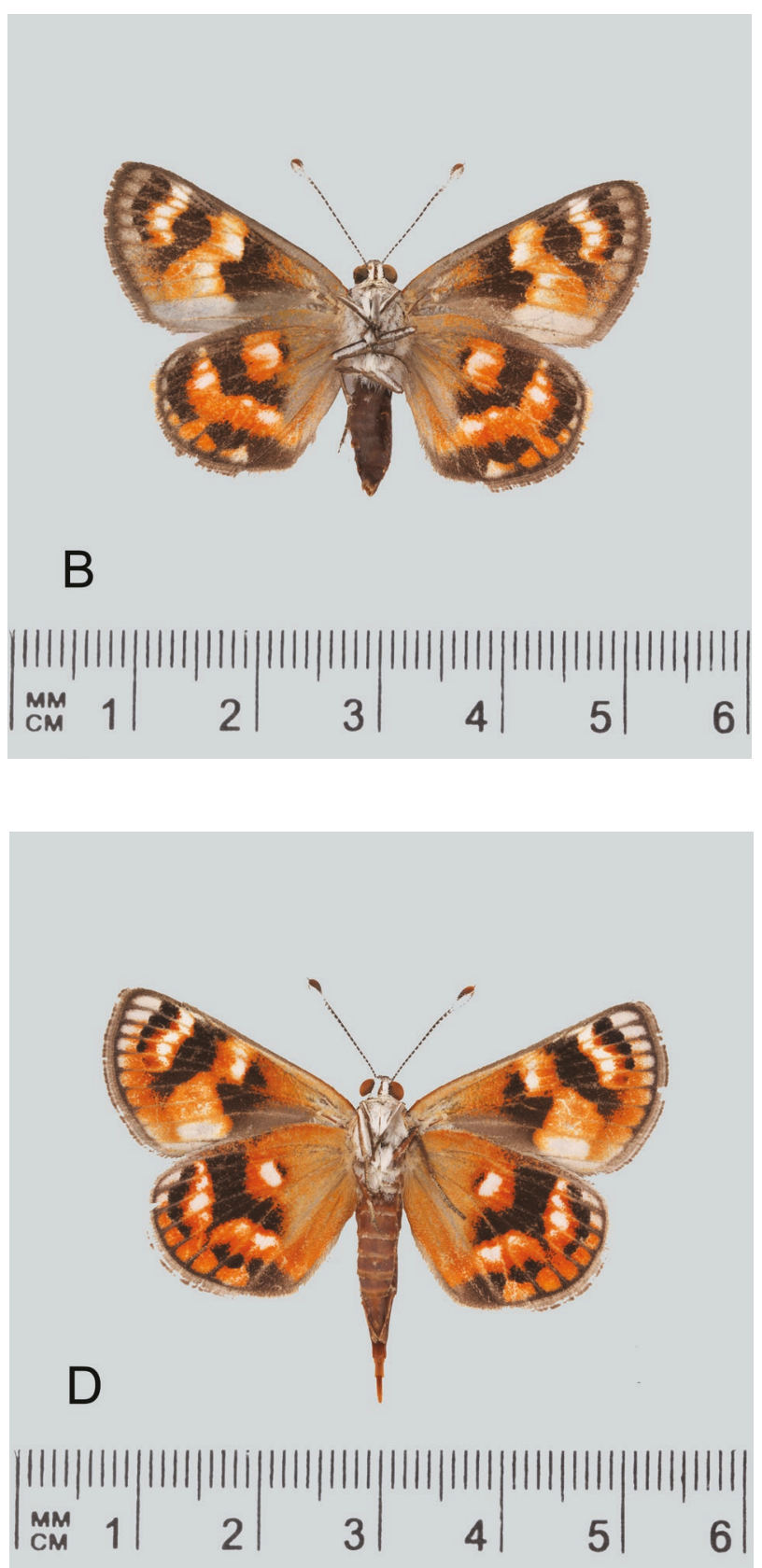

FIGURE 32 Synemonsp. 'Mount Dale'. A, ô Dorsal; B, Ő Ventral (C2673) Western Australia, Jarrahdale (WAM); C, o Dorsal; D, q Ventral (C1294) Western Australia, Metro Road, Brookton Highway (WAM). (Photos: Brian Hanich, Western Australian Museum.) 


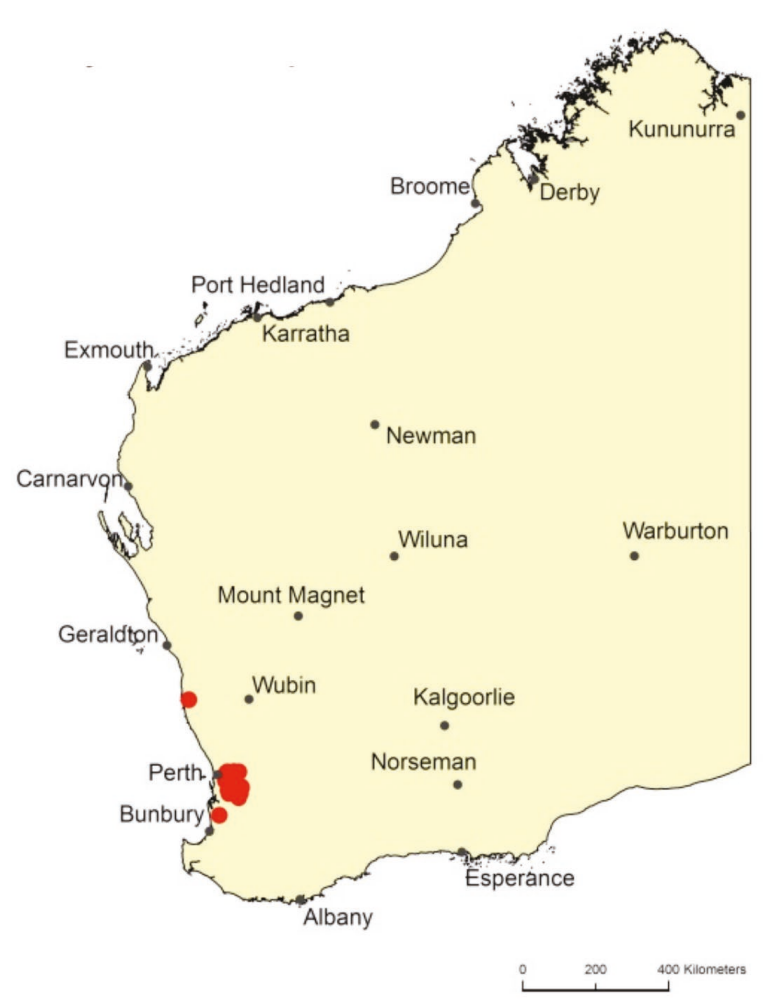

FIGURE 33 Map of Western Australia showing distribution of Synemon sp. 'Mount Dale'.

\section{LARVAL FOOD PLANT}

The larval food plant is the large prominent semaphore sedge Mesomelaena tetragona (R. Br.) Benth., which often grows on laterite, or on sand with a laterite component.

\section{HABITAT}

In its cluster of southern localities, $S$. sp. 'Mount Dale' is invariably found in Marri (Corymbia calophylla) and/or Jarrah (Eucalyptus marginata) dominated forest or woodland where the understory has a major component of $M$. tetragona. The isolated northern sun-moth population at Mount Peron occurs in low species rich heathland on an upper hill slope, where surface laterite outcrops through the sand. Mesomelaena tetragona is locally common at this site. Because sun-moths have an obligate dependence on suitable plants for breeding, the distribution of the larval food plant(s) determines the potential habitat (Williams M. et al. 2012). In this case the distribution of $M$. tetragona enables $S$. sp. 'Mount Dale' to occupy both sheltered woodland habitats in the south and very exposed windswept low heathland in the north.

\section{BEHAVIOUR AND FLIGHT PERIOD}

This fast flying sun-moth is active in sunny conditions. In woodland localities near Perth, males establish territories, which they actively defend against other, intruding males. They frequently settle with wings closed on fallen sticks or the upright stems of semaphore sedges, where they resemble the dark sedge seed-head. At the peak of the flight period the species may be locally common. At the isolated Mount Peron site, S. sp. 'Mount Dale' flies in late November and early December, and because of the frequent windy conditions tends to fly close to the ground, where there is some shelter from the from wind. The main flight period further south is late December and January. Occasionally late flying individuals are seen in early February.

\section{CONSERVATION STATUS}

Not threatened. Although this taxon has a relatively small range, it occurs in conservation estate including State forest and national parks. The common name 'Semaphore Sun-moth' denotes the sun-moth's larval food plant, the large semaphore sedge $M$. tetragona. There are seven historical and 16 recent records.

\section{HISTORICAL RECORDS}

Kalamunda, $31^{\circ} 58^{\prime} 00^{\prime \prime} \mathrm{S}, 116^{\circ} 03^{\prime} 00^{\prime \prime}$ E, 01 Jan 1926, W.B. Barnard (QM); Hovea, 31 ${ }^{\circ} 53^{\prime} 00^{\prime \prime}$ S, $116^{\circ}$ 16' 00" E, 25 Jan 1934, K.R. Norris; North of Bannister, coordinates not recorded, 05 Jan 1961, M.S. Moulds; Mount Peron, 30 07' 00" S, $115^{\circ} 09^{\prime} 00^{\prime \prime}$ E, 28 Nov 1978, collector unknown; Mount Cook, 32 $25^{\prime}$ 00" S, $116^{\circ} 08^{\prime} 00^{\prime \prime}$ E, 23-25 Jan 1985, S. Barker and R.P. McMillan (WAM); Mount Dale, $32^{\circ} 08^{\prime} 00^{\prime \prime} \mathrm{S}, 116^{\circ} 18^{\prime}$ 00" E, 29 Dec 1987, R.W. Hay; Yarloop, 32 57' 00" S, $115^{\circ} 54^{\prime}$ 00" E, 11 Jan 1991, M.S. Moulds and B.J. Moulds.

\section{RECENT RECORDS}

Metro Road, near Brookton Highway, 32 $14^{\prime} 55^{\prime \prime} \mathrm{S}$, $116^{\circ} 26^{\prime}$ 47" E, 31 Dec 2010, A.A.E. Williams; Base of Mount Dale, Bibbulmun Hut, $32^{\circ} 07^{\prime} 56^{\prime \prime}$ S, $116^{\circ} 17^{\prime} 47^{\prime \prime}$ E, 02 Jan 2012, A.A.E. Williams; $1.1 \mathrm{~km} \mathrm{~S}$ of Blue Rock, Jarrahdale, 32 $20^{\prime} 21^{\prime \prime}$ S, $116^{\circ} 06^{\prime} 49^{\prime \prime}$ E, 16 Jan 2012, A.A.E. Williams; Brookton Highway, $32^{\circ} 10^{\prime} 28^{\prime \prime} \mathrm{S}, 116^{\circ}$ 14' 07" E, 17 Jan 2012, A.A.E. Williams; Roleystone, Canning Mills Road, $32^{\circ} 05^{\prime} 50^{\prime \prime} \mathrm{S}, 116^{\circ} 02^{\prime} 4^{\prime \prime}$ E, 17 Jan 2012, A.A.E. Williams; State Forest, Kinsella Road, $32^{\circ}$ 11' 30" S, $116^{\circ} 11^{\prime} 29^{\prime \prime}$ E, 17 Jan 2012, A.A.E. Williams; Brookton Highway, 32 $11^{\prime} 22^{\prime \prime}$ S, $116^{\circ} 15^{\prime} 31^{\prime \prime}$ E, 18 Jan 2012, F. Hort and J. Hort; Korung National Park, $32^{\circ} 03^{\prime}$ 29" S, $116^{\circ} 06^{\prime} 21^{\prime \prime}$ E, 19 Jan 2012, A.A.E. Williams; 36 $\mathrm{km}$ E of The Lakes, 31 52' 46" S, 116 23' 11" E, 21 Jan 2012, A.A.E. Williams; John Forrest National Park, $31^{\circ}$ 53' 56" S, $116^{\circ} 05^{\prime}$ 24" E, 21 Jan 2012, A.A.E. Williams; Mundaring Weir Road, $31^{\circ} 56^{\prime}$ 06" S, $116^{\circ} 10^{\prime} 55^{\prime \prime}$ E, 21 Jan 2012, A.A.E. Williams; Gibbs Forest, Watershed Road, 32 24' 38" S, $116^{\circ} 25^{\prime}$ 17" E, 11 Feb 2012, A.A.E. Williams; $9 \mathrm{~km} \mathrm{NW}$ of North Bannister, 32 $32^{\prime}$ 57" S, $116^{\circ} 22^{\prime} 43^{\prime \prime}$ E, 01 Jan 2013, A.A.E. Williams; Lesueur National Park, Mount Peron, 30 06' 41" S, 1150 09' 06" E, 04 Dec 2014, A.A.E. Williams; $1.3 \mathrm{~km} \mathrm{~S}$ of Chidlow, $31^{\circ}$ $52^{\prime} 30^{\prime \prime}$ S, $116^{\circ} 15^{\prime} 46^{\prime \prime}$ E, 15 Jan 2015, A.A.E. Williams; Greenmount National Park, $31^{\circ} 54^{\prime} 28^{\prime \prime} \mathrm{S}, 116^{\circ} 04^{\prime} 11^{\prime \prime}$ E, 20 Jan 2015, F. Hort and J. Hort. 


\section{Synemon sp. 'Ravensthorpe' (Narrow-winged Sun-moth)}

Figure 34

\section{BRIEF DESCRIPTION}

This is a distinctive, medium sized sun-moth. The sexes are similar, though males may be considerably smaller than females. Males vary in size from 32 to $40 \mathrm{~mm}$, females from 40 to $45 \mathrm{~mm}$. Females have particularly long narrow forewings, which give them a very elongate appearance when settled. In both sexes, the upper side of the forewing has a patchwork pattern
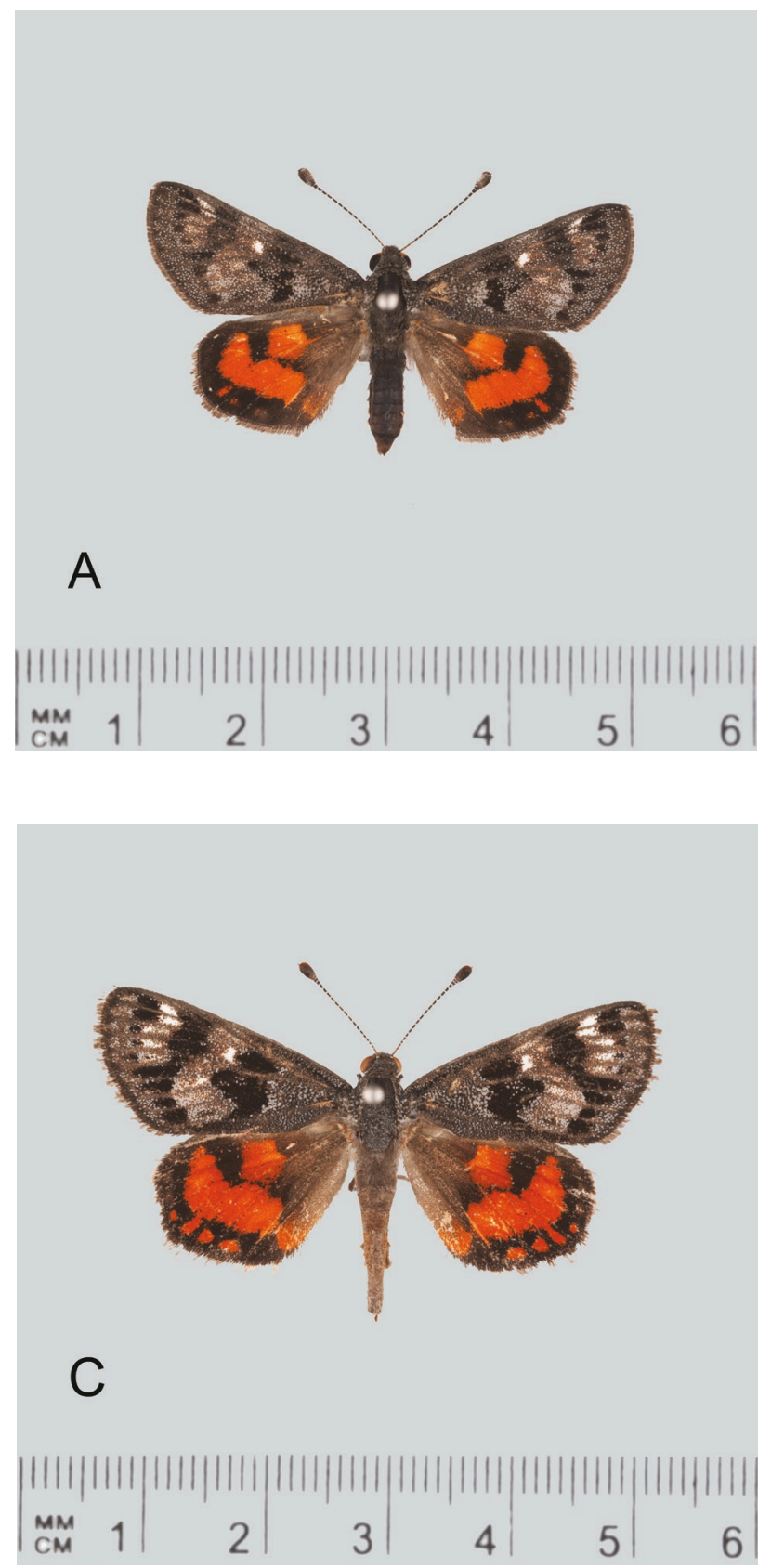

of black and varying shades of grey, sometimes with discrete small subcostal and subapical white spots. The hind wing ground colour is dull black with a very large orange-red discal spot and a very broad orangered postmedian band. This band extends across the hind wing and often enters the dorsum alongside the abdomen. The black border along the trailing edge of the hind wing encloses from one to four very small orangered subterminal spots. In males, the underside of the forewing is blackish-grey, with two dull orange bands which are spotted in white, while the underside of the hind wing is predominantly orange with black and white
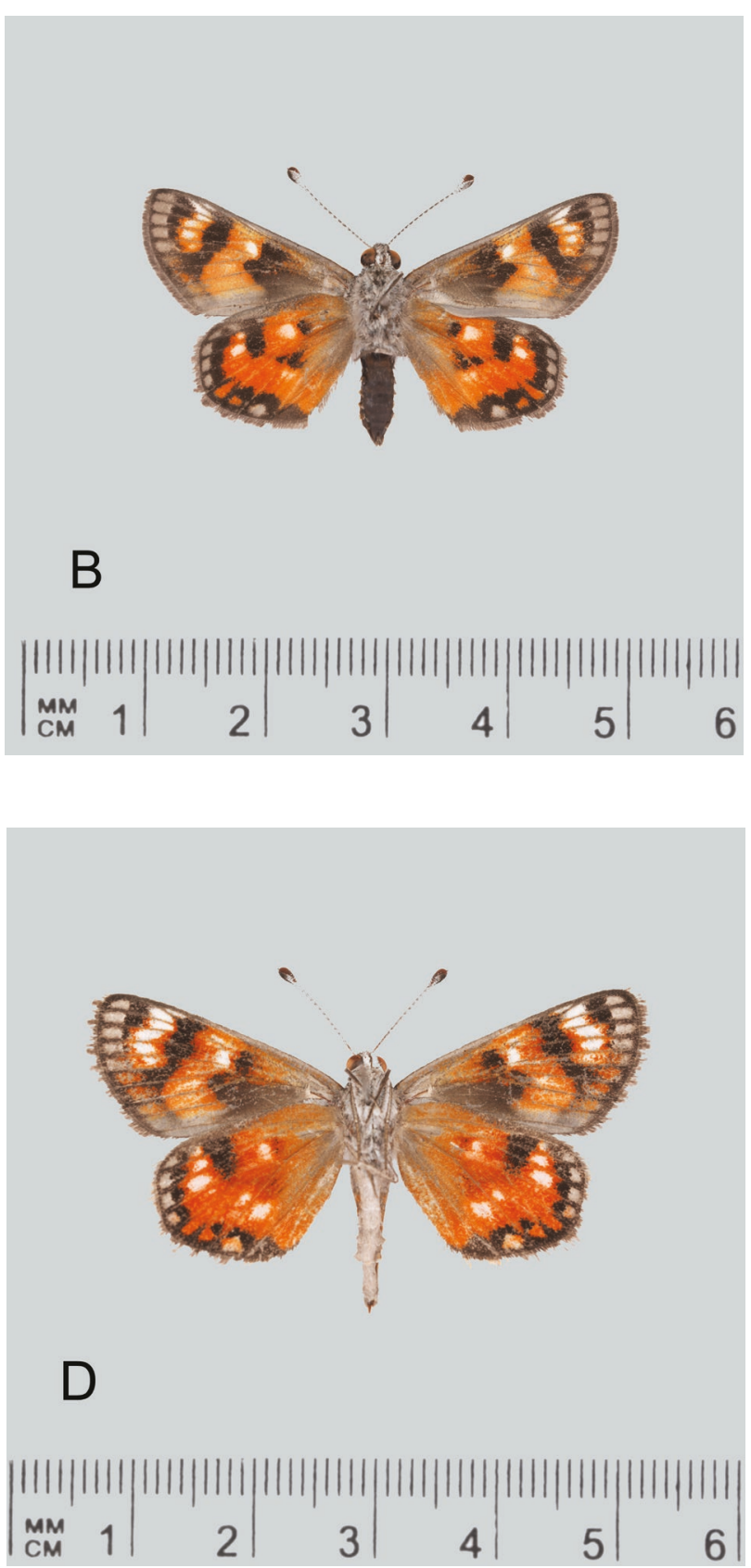

FIGURE 34 Synemon sp. 'Ravensthorpe'. A, ô Dorsal; B, ô Ventral (C3244) Western Australia, Israelite Bay (WAM); C, o Dorsal; D, o Ventral (C3249) Western Australia, Israelite Bay (WAM). (Photos: Nikolai Tatarnic, Western Australian Museum.) 
spots and markings. In females the underside pattern is similar, but the orange colouration is more extensive.

\section{DISTRIBUTION}

This sun-moth is a rare Western Australian endemic. It is known from very few south-eastern coastal and nearcoastal localities. The original specimens were collected $26 \mathrm{~km}$ east of Ravensthorpe and at Sheoaks Hill in Nuytsland Nature Reserve in 1993. An intermediate locality was identified at Fields Nature Reserve in 1999. Since then, however, the only location where $S$. sp. 'Ravensthorpe' has been found is in Nuytsland Nature Reserve close to the coast north-east of Israelite Bay (Figure 35).

\section{LARVAL FOOD PLANT}

The larval food plant is Hook-leaf Saw Sedge Gahnia ancistrophylla Benth.

\section{HABITAT}

Near Ravensthorpe this sun-moth occurs in mixed low mallee woodland with sparse low shrubs and patches of $G$. ancistrophylla sedge, growing on laterite gravel and clay-sand. North-east of Israelite Bay the sunmoths occur alongside a series of saline lakes, where the vegetation is a Melaleuca sp. dominated shrubland with an understory of $G$. ancistrophylla. This vegetation

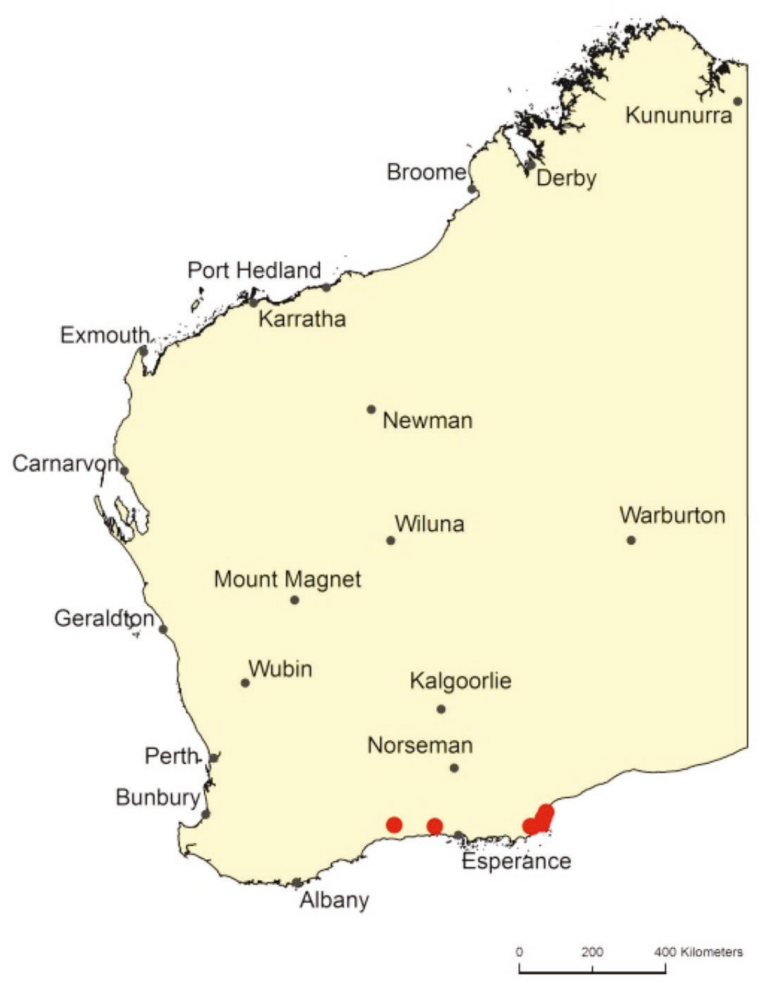

FIGURE 35 Map of Western Australia showing distribution of Synemon sp. 'Ravensthorpe'. association grows in shallow white sand overlying pavement limestone.

\section{BEHAVIOUR AND FLIGHT PERIOD}

This is a moderately fast flying sun-moth. Near Ravensthorpe specimens were collected in January 1993, flying close to the ground on an old roadside gravel scrape (E.D. Edwards, personal communication, 2011). On the telegraph track north of Israelite Bay the sun-moths were active alongside the main sand track where $G$. ancistrophylla sedges had regenerated on scraped flattened road verges. Females were observed ovipositing on sedges where empty pupal exuvia were collected. Synemon sp. 'Ravensthorpe' has been recorded in early January and undoubtedly flies in late December as well.

\section{CONSERVATION STATUS}

Data deficient. The species is known from very few sites. The primary population is centred on Israelite Bay and north-east along the coast within Nuytsland Nature Reserve. Further surveys for this sun-moth are required in other areas where its larval food plant is known to occur. Any mineral exploration activity in Nuytsland Nature Reserve will inevitably undermine the nature conservation values of this remote coastal wilderness and impact negatively on the few known colonies of this rare sun-moth. There are three historical and 10 recent records.

\section{HISTORICAL RECORDS}

Israelite Bay, Sheoaks Hill, $33^{\circ} 37^{\prime} 48^{\prime \prime} \mathrm{S}, 123^{\circ} 39^{\prime}$ 36" E, 08 Jan 1993, E.D. Edwards and E.S. Nielsen; 26 km E of Ravensthorpe, 33 36' 00" S, 120 18' 00" E, 10 Jan 1993, E.D. Edwards and E.S. Nielsen; Fields Nature Reserve, 33 38' 00" S, $121^{\circ} 18^{\prime} 00^{\prime \prime}$ E, 31 Jan 1999, M. Golding and M. Powell.

\section{RECENT RECORDS}

Israelite Bay, Telegraph Track, $33^{\circ} 26.291^{\prime} \mathrm{S}, 123^{\circ}$ 58.929' E, 11 Jan 2014, D.J. Hilton; Israelite Bay, Telegraph Track, 33 26' 17" S, $123^{\circ} 58^{\prime} 56^{\prime \prime}$ E, 01 Jan 2015, A.A.E. Williams; Israelite Bay, Gora Road, $33^{\circ} 38^{\prime} 24^{\prime \prime} \mathrm{S}, 123^{\circ} 42^{\prime} 20^{\prime \prime}$ E, 03 Jan 2015, A.A.E. Williams; Israelite Bay, Gora Road, $33^{\circ} 38^{\prime} 38^{\prime \prime} \mathrm{S}, 123^{\circ}$ 42' 42" E, 03 Jan 2015, A.A.E. Williams; Israelite Bay, Telegraph Track, 33 34' 08" S, $123^{\circ} 56^{\prime} 25^{\prime \prime}$ E, 04 Jan 2015, A.A.E. Williams; Israelite Bay, Telegraph Track, $33^{\circ} 26^{\prime} 22^{\prime \prime} \mathrm{S}, 123^{\circ} 58^{\prime} 55^{\prime \prime}$ E, 04 Jan 2015, A.A.E. Williams; Israelite Bay, Telegraph Track, 33 $26^{\prime} 16^{\prime \prime} \mathrm{S}$, $123^{\circ} 58^{\prime}$ 56" E, 04 Jan 2015, A.A.E. Williams; Israelite Bay, Telegraph Track, 33 24' 31" S, $123^{\circ} 59^{\prime} 12^{\prime \prime}$ E, 04 Jan 2015, A.A.E. Williams; Israelite Bay, Telegraph Track, 33 ${ }^{\circ} 24^{\prime} 17^{\prime \prime} \mathrm{S}, 123^{\circ} 59^{\prime} 16^{\prime \prime}$ E, 04 Jan 2015, A.A.E. Williams; Israelite Bay, Telegraph Track, $33^{\circ}$ $16^{\prime} 53^{\prime \prime}$ S, $124^{\circ} 02^{\prime} 32^{\prime \prime}$ E, 04 Jan 2015, A.A.E. Williams. 


\section{Synemon laeta species group}

\section{Synemon edwardsi Williams and Williams 2016 (Splendid Sun-moth)}

Figure 36

\section{BRIEF DESCRIPTION}

Though small, S. edwardsi is a very striking sunmoth. Males have elongate, pointed forewings, while females have rounded forewings. In both sexes, the upper side of the forewing is uniformly grey, with two
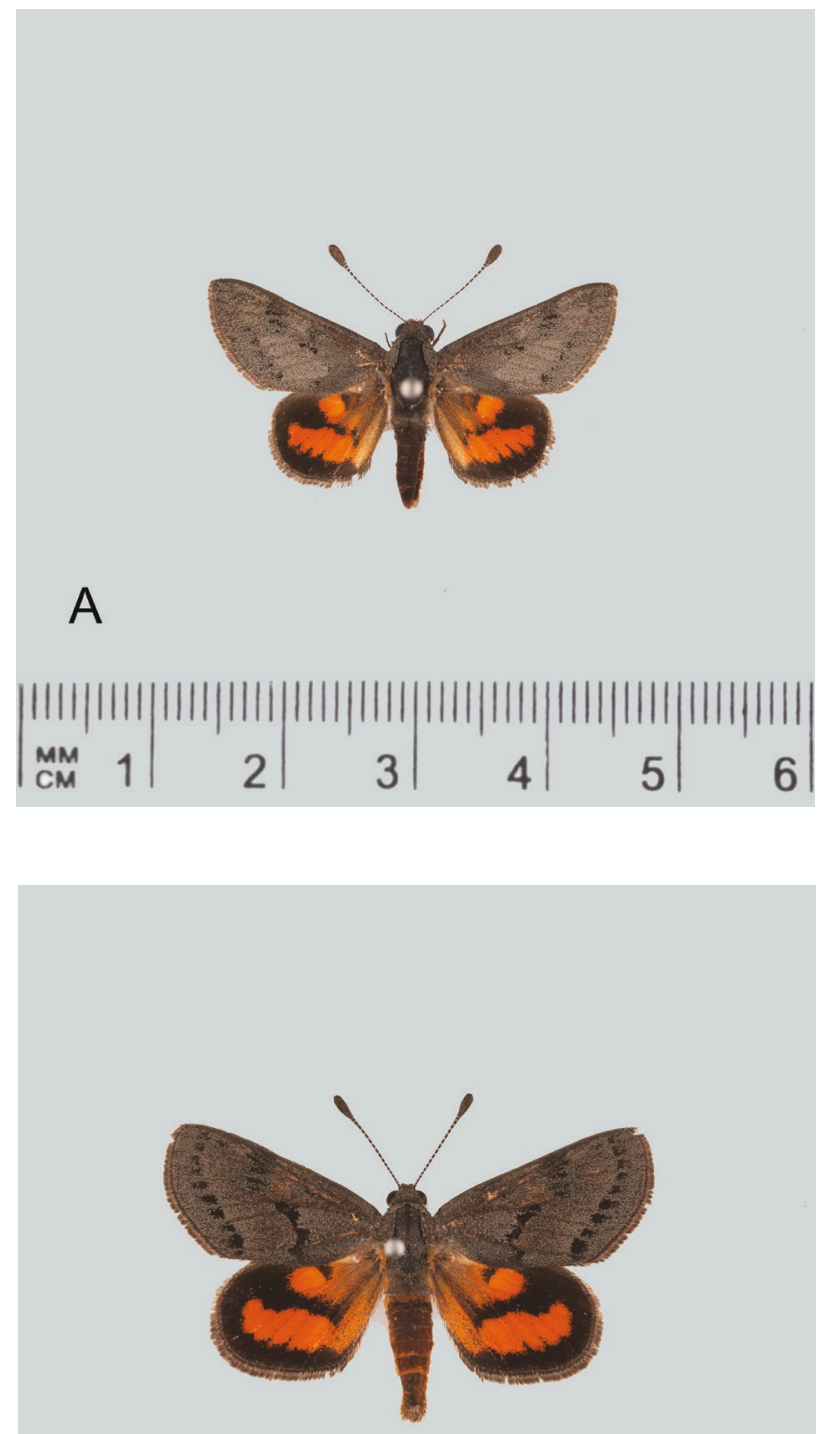

\section{C}

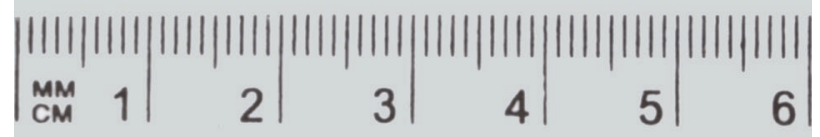

oblique parallel broken black lines. In males the upper side of the hind wing is a very deep bright orange, broadly bordered in black, and almost always with a continuous, if irregular, black band across the centre. In females too the upper side of the hind wing is bright orange, broadly bordered black, with a solid broad black central band which tapers up alongside the dorsum, parallel with the abdomen. In males, the underside of both fore and hind wings is dull orange, with diffuse black and greyish-black markings. There are three small whitish markings in the subapical part of the forewing. In females, the underside is largely orange with bolder

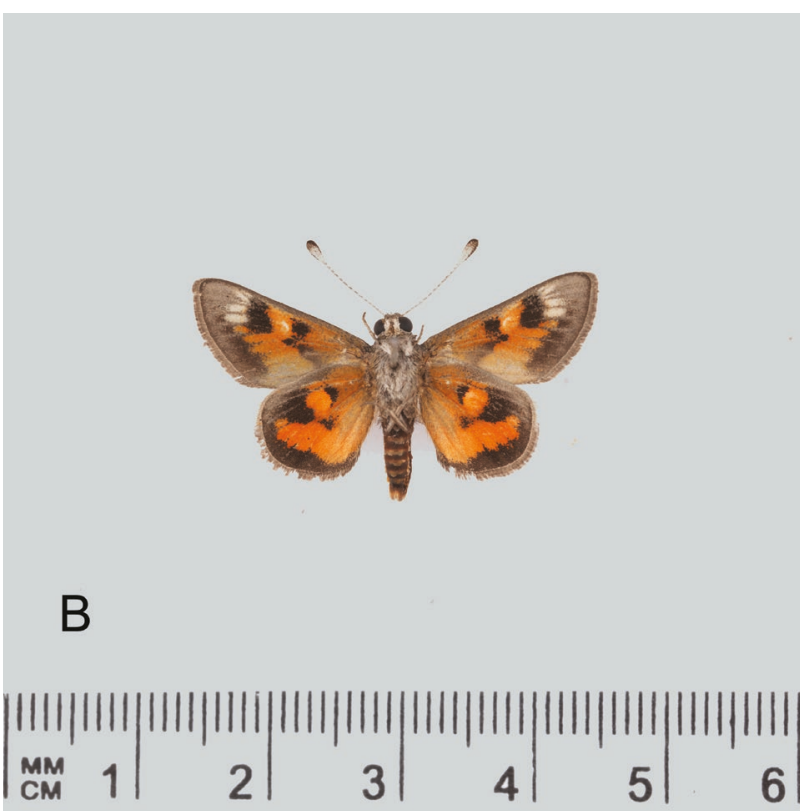

\section{D}

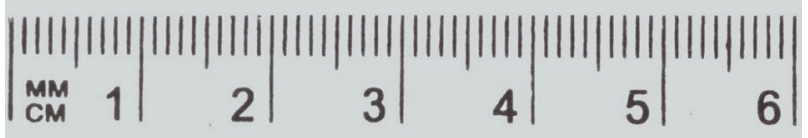

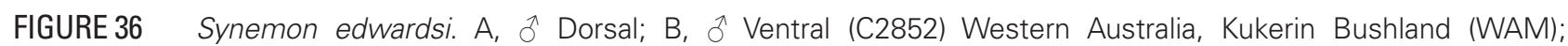
C, o Dorsal; D, o Ventral (C2856) Western Australia, North Tarin Rock Nature Reserve (WAM). (Photos: Nikolai Tatarnic, Western Australian Museum.) 
black markings. The outer edge of both wings has a broad blackish border, and a black band extends partway across the centre of the hind wing. Note: In an earlier publication (Williams and Williams 2013b), this taxon was referred to as Synemon sp. 'Kukerin'.

\section{DISTRIBUTION}

This sun-moth is a Western Australian endemic. It is known from ten localities, all in the central and southern Wheatbelt - from Charles Gardner Nature Reserve, near Tammin, south to Kukerin and east to the western boundary of Frank Hann National Park (Figure 37).

\section{LARVAL FOOD PLANT}

The larval food plant is Chamaexeros fimbriata (F. Muell.) Benth.

\section{HABITAT}

The usual habitat is open mixed mallee or shrubland over open low heath and sedges, where the larval food plant grows. The upper story is frequently dominated by Tamma (Allocasuarina campestris).

\section{BEHAVIOUR AND FLIGHT PERIOD}

This small, fast flying sun-moth occurs in small isolated colonies, where it invariably flies close to the ground. Males set up territories in areas of open ground,

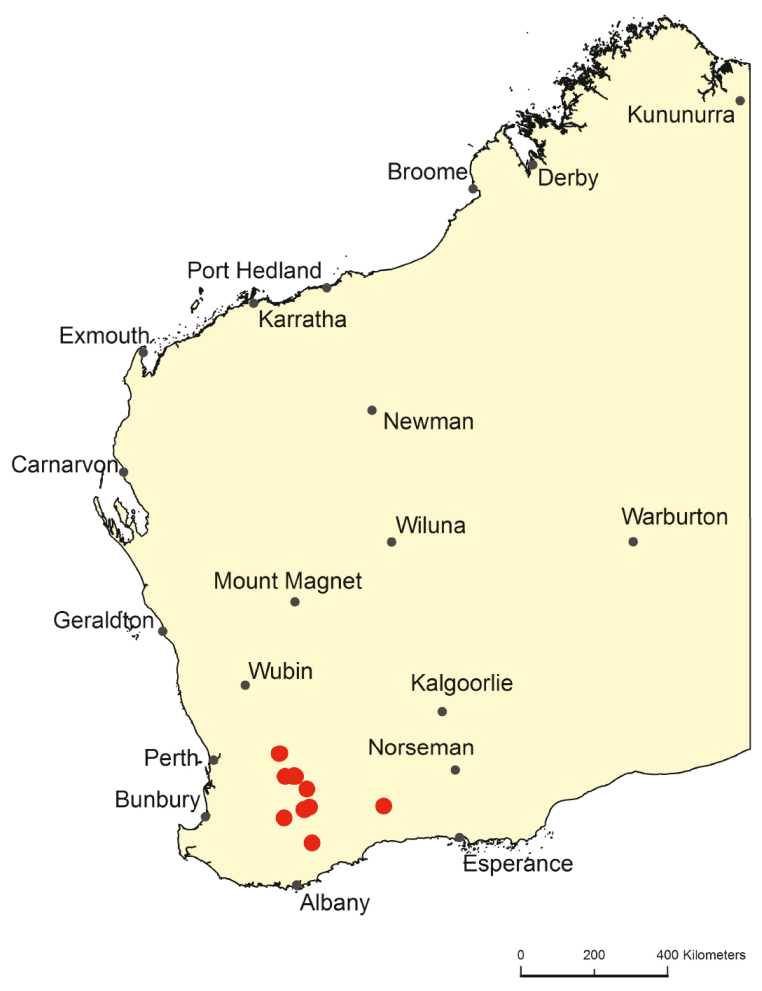

FIGURE 37 Map of Western Australia showing distribution of Synemon edwardsi. and will use low termite mounds as perching points, if they are available. Females are less frequently observed. The sun-moths are active in warm to hot, sunny conditions from mid morning to mid afternoon, and (like many other species) will become inactive if cloudcover forms. The flight period lasts for approximately two weeks, in November. The timing of emergence varies from year to year. In dry years the species appears in early November, but in cooler, wetter seasons it does not fly until later in the month (Williams and Williams 2013b, 2016a).

\section{CONSERVATION STATUS}

Data deficient. In view of predicted drying trends for the Western Australian Wheatbelt, this taxon may be regarded as threatened in the northern parts of its range, where it is restricted to a few small remnant patches of native vegetation (Williams and Williams 2013b). Known colonies are very small and local. Further surveys are required to determine whether $S$. edwardsi is present in the extensive moister heathlands south and east of Frank Hann National Park (Williams and Williams 2013b), where the larval food plant $C$. fimbriata is known to occur. There are two historical and 12 recent records.

\section{HISTORICAL RECORDS}

Kukerin, location not recorded, 1948, A.M. Douglas (WAM); Charles Gardner Nature Reserve, $31^{\circ} 47^{\prime} 00^{\prime \prime} \mathrm{S}$, $117^{\circ} 28^{\prime} 56^{\prime \prime}$ E, 21 Nov 1996, T.F. Houston (WAM).

\section{RECENT RECORDS}

Kukerin Bushland, 33 10' 26" S, $118^{\circ} 04^{\prime}$ 39" E, 01 Nov 2010, A.A.E. Williams; Kulin Bushland, 32 39' 48" S, $118^{\circ} 08^{\prime}$ 27" E, 01 Nov 2010, A.A.E. Williams; Corrigin Bushland (north-west), 32 $22^{\prime} 18^{\prime \prime} \mathrm{S}, 117^{\circ}$ 49' 55" E, 01 Nov 2010, A.A.E. Williams; Charles Gardner Nature Reserve, $31^{\circ} 47^{\prime} 27^{\prime \prime} \mathrm{S}, 117^{\circ} 27^{\prime}$ 51" E, 02 Nov 2010, A.A.E. Williams; Corrigin Bushland (south-east), 32 $21^{\circ} 10^{\prime \prime} \mathrm{S}, 117^{\circ} 51^{\prime} 38^{\prime \prime}$ E, 08 Nov 2010, A.A.E. Williams; Frank Hann National Park (boundary), 33 04' 48" S, 120 01' 36" E, 22 Nov 2011, A.A.E. Williams; Kunjin Bushland, 32 $21^{\prime} 08^{\prime \prime} \mathrm{S}$, $117^{\circ} 48^{\prime} 13^{\prime \prime}$ E, 07 Nov 2012, A.A.E. Williams; Tarin Rock Nature Reserve, $33^{\circ} 06^{\prime}$ 26" S, $118^{\circ} 12^{\prime}$ 25" E, 08 Nov 2012, A.A.E. Williams; North Tarin Rock Nature Reserve, $33^{\circ} 58^{\prime}$ 53" S, $118^{\circ} 16^{\prime}$ 01" E, 08 Nov 2012, A.A.E. Williams; Overhue Nature Reserve, $33^{\circ} 22^{\prime}$ 23" S, $117^{\circ} 34^{\prime}$ 58" E, 13 Nov 2012, A.A.E. Williams; North Lomos Road, near Corrigin, 32 $21^{\prime} 26^{\prime \prime} \mathrm{S}, 117^{\circ}$ 36' 37" E, 13 Nov 2012, A.A.E. Williams; Charles Gardner Nature Reserve, $31^{\circ} 47^{\prime} 27^{\prime \prime}$ S, $117^{\circ} 27^{\prime}$ 51" E, 12 Nov 2013, E.D. Edwards and M.R. Williams (ANIC). 


\section{Synemon gratiosa Westwood 1877 (Graceful Sun-moth)}

Figure 38

\section{BRIEF DESCRIPTION}

Synemon gratiosa is one of the smallest sun-moths in Western Australia. Males are smaller than females and have pointed, rather than rounded, forewings. In both sexes, the upper side of the forewing is variably patterned with cryptic grey, brown, black, and whitish markings. The upper side of the hind wing is orange, with variable blackish markings along the outer border, and sometimes a narrow curved black central band. In some individuals the upper side of the hind wing is entirely orange, apart from a narrow dark border. The underside is predominantly orange, more extensively in females. S. gratiosa specimens from the southernmost part of the range have more extensive black markings, including a solid black band crossing the upper side of the hind wing.

\section{DISTRIBUTION}

Synemon gratiosa is a Western Australian endemic, with an extensive but disjunct near-coastal distribution, from Binningup, in the south, to Kalbarri and
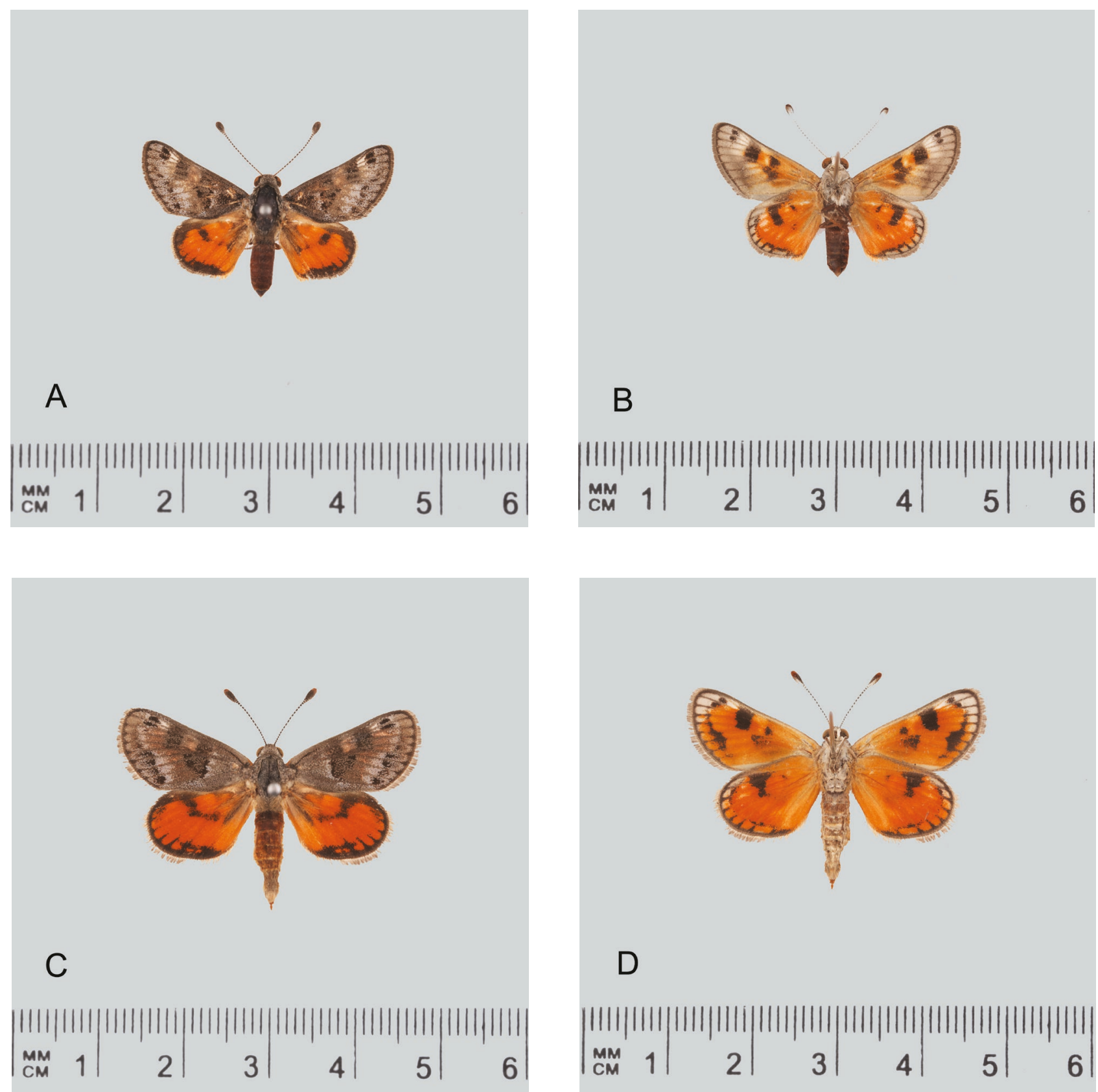

FIGURE 38 Synemon gratiosa. A, ổ Dorsal; B, ô Ventral (C1671) Western Australia, Perth, Tamala Park (WAM); C, o Dorsal; D, o Ventral (C1800) Western Australia, Perth, Yanchep (WAM). (Photos: Brian Hanich, Western Australian Museum.) 
Murchison House Station, in the north (Williams M. et al. 2012; Williams A. et al. 2012). Near Perth, the species is also found on the Swan Coastal Plain and at the base of the Darling Scarp (near Bullsbrook and at Talbot Nature Reserve in Stratton). In the Jarrah (Eucalyptus marginata) forest east of Perth, there are several small, local populations where individuals display genetic affiliations to both $S$. gratiosa and $S$. jcaria. These unusual, probably hybrid populations, are identified with blue dots on the $S$. gratiosa distribution map (Figure 39).

\section{LARVAL FOOD PLANT}

The larval food plants are two closely related mat-rushes, Lomandra maritima T.S. Choo and Lomandra hermaphrodita (C.R.P. Andrews) C.A. Gardner (Williams M. et al. 2012).

\section{HABITAT}

Synemon gratiosa occurs predominantly on coastal and near-coastal dunes, where the larval food plant, L. maritima, is often widespread and abundant. On the Swan Coastal plain near Perth $S$. gratiosa is found mainly in Banksia woodlands where L. hermaphrodita is the larval food plant.

\section{BEHAVIOUR AND FLIGHT PERIOD}

This sun-moth is active in hot, sunny conditions. In coastal areas males establish territories on dune ridges and dune crests, in the vicinity of the larval food plant. Males typically fly close to the ground for short periods, before settling on the ground, a stick or a shrub at a prominent vantage point. They actively defend these territories against intruding males. When an unmated female enters a male's territory, the male will immediately pursue the female until she lands, when copulation takes place. In Banksia woodland, males frequently establish territories in open sandy patches where the larval food plants grow. The females are seen less frequently. The flight period for S. gratiosa is mid February to early April. Adults appear earlier in southern than in northern localities.

\section{CONSERVATION STATUS}

This species is listed Federally as 'near-threatened' and as a 'priority 4' species under Western Australian State legislation. About $15-20 \%$ of its known habitat is scheduled to be cleared within the next 10 years, which can be expected to cause the loss of a similar proportion of the total population (Williams M, 2012). Fortunately, populations also occur in some large conservation reserves, including Yalgorup National Park, south of Perth, and Wanagarren Nature Reserve, Nambung National Park, Beekeepers Nature Reserve and Kalbarri National Park, north of Perth. There are 14 historical and 75 recent records.

\section{HISTORICAL RECORDS}

Perth (general), $31^{\circ} 57^{\prime} 00^{\prime \prime} \mathrm{S}, 115^{\circ} 57^{\prime} 00^{\prime \prime} \mathrm{E}$, date not recorded, collector unknown (WAM); Kings Park, $31^{\circ}$ 58' 12" S, $115^{\circ} 49^{\prime} 48^{\prime \prime} \mathrm{E}$, date not recorded, collector unknown (WAM); Swan River, $31^{\circ} 51^{\prime} 00^{\prime \prime}$ S, $116^{\circ} 00^{\prime}$
00" E, date not recorded, J. Clark (DAFC); Swan River, $31^{\circ} 51^{\prime} 00^{\prime \prime} \mathrm{S}, 116^{\circ} 00^{\prime} 00^{\prime \prime} \mathrm{E}$, date not recorded, L.J. Newman (WAM); Naval Base, $32^{\circ} 12^{\prime} 00^{\prime \prime} \mathrm{S}, 115^{\circ} 46^{\prime}$ $48^{\prime \prime} \mathrm{E}$, date not recorded, C.F. Jenkins (WAM); Crawley, $31^{\circ} 57^{\prime} 00^{\prime \prime} \mathrm{S}, 115^{\circ} 51^{\prime} 00^{\prime \prime} \mathrm{E}, 26$ Feb 1935, K.R. Norris (WAM); Fremantle, $32^{\circ} 04^{\prime} 12^{\prime \prime} \mathrm{S}, 115^{\circ} 45^{\prime} 00^{\prime \prime} \mathrm{E}, 03$ Mar 1935, K.R. Norris (WAM); Applecross, $32^{\circ} 01^{\prime} 12^{\prime \prime}$ S, $115^{\circ} 49^{\prime} 48^{\prime \prime}$ E, 17 Mar 1951, D.G. Shedley (WAM); Jandakot, 32 $07^{\prime} 12^{\prime \prime}$ S, $115^{\circ} 4^{\prime} 9^{\prime} 48^{\prime \prime}$ E, 15 Mar 1969, F.O. Donnell (WAM); Sorrento, 31 $41^{\prime} 48^{\prime \prime} \mathrm{S}, 115^{\circ} 45^{\prime}$ 00" E, 24 Mar 1971, B. Wilson (WAM); Swanbourne, $31^{\circ} 58^{\prime} 48^{\prime \prime} \mathrm{S}, 115^{\circ} 46^{\prime} 12^{\prime \prime}$ E, 21 Feb 1976, M. Powell (WAM); Mandurah, 32० 31' 48" S, $115^{\circ} 43^{\prime} 12^{\prime \prime}$ E, 16 Feb 1984, R.W. Hay (WAM); Wanneroo, $31^{\circ} 45^{\prime} 00^{\prime \prime} \mathrm{S}, 115^{\circ}$ 48' 00" E, 18 Mar 1984, R.W. Hay (WAM); Neerabup, Flynn Drive, 31 40' 48" S, 115 48' 00" E, 19 Mar 1996, E.D. Edwards and E.S. Nielsen.

\section{RECENT RECORDS}

Perth, Koondoola Bushland, $31^{\circ} 50^{\prime} 03^{\prime \prime}$ S, $115^{\circ} 51^{\prime}$ 47" E, 27 Mar 2002, M.R. Williams; Yalgorup National Park, White Hill, 32 ${ }^{\circ} 41^{\prime} 21^{\prime \prime}$ S, $115^{\circ} 37^{\prime} 01^{\prime \prime}$ E, 15 Feb 2010, A.A.E. Williams; Preston Beach, 32 53' 27" S, $115^{\circ} 39^{\prime}$ 32" E, 16 Feb 2010, J. Abery; Yalgorup,

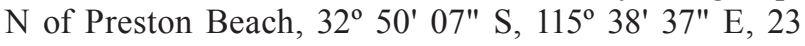
Feb 2010, A.A.E. Williams; Perth, Ocean Reef Boat

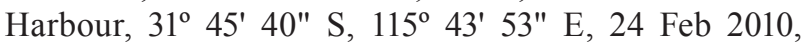
A.A.E. Williams; Yanchep Water Block, 31 $31^{\circ} 11^{\prime \prime}$ S, $115^{\circ} 38^{\prime} 44^{\prime \prime}$ E, 26 Feb 2010, C.L. Bishop; Perth,

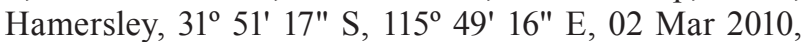
G. Harewood and J. Lisle; Wilbinga (north-east), $31^{\circ}$ 24' 02" S, 115 34' 08" E, 03 Mar 2010, C.L. Bishop and J. Fissioli; Perth, Eglinton, $31^{\circ} 37^{\prime} 17^{\prime \prime} \mathrm{S}, 115^{\circ} 41^{\prime}$ 29" E, 04 Mar 2010, P. Mitrovski; Yanchep, Pipidinny Road (north), 31 34' 19" S, $115^{\circ} 40^{\prime} 56^{\prime \prime}$ E, 05 Mar 2010, C.L. Bishop and J. Fissioli; Point Peron, 32 $17^{\prime} 06^{\prime \prime}$ S, $115^{\circ} 42^{\prime} 22^{\prime \prime}$ E, 08 Mar 2010, M. Brown; Southern Beekeepers Nature Reserve, 30 28' 19" S, $115^{\circ} 06^{\prime} 35^{\prime \prime}$ E, 15 Mar 2010, A.A.E. Williams; Nambung National Park, 30 33' 44" S, $115^{\circ} 05^{\prime}$ 41" E, 16 Mar 2010, A.A.E. Williams; Jurien Bay, $30^{\circ} 16^{\prime} 57^{\prime \prime} \mathrm{S}, 115^{\circ} 04^{\prime}$ 06" E, 17 Mar 2010, A.A.E. Williams; Nilgen Nature Reserve, 30 59' 12" S, $115^{\circ} 21^{\prime} 46^{\prime \prime}$ E, 18 Mar 2010, A.A.E. Williams; Wilbinga South Coast, $31^{\circ} 26^{\prime} 21^{\prime \prime}$ S, $115^{\circ} 33^{\prime} 31^{\prime \prime}$ E, 18 Mar 2010, J. Fissioli, P. Cavalli and A. Reaveley; Perth, Gnangara Bush-Forever Site, $31^{\circ} 47^{\prime} 16^{\prime \prime} \mathrm{S}, 115^{\circ} 51^{\prime} 12^{\prime \prime}$ E, 18 Mar 2010, Coffey Environments; Perth, Tamala Park, $31^{\circ} 41^{\prime} 59^{\prime \prime} \mathrm{S}, 115^{\circ}$ 42' 39" E, 26 Mar 2010, J. Purvis; Preston Beach Townsite, $32^{\circ} 52^{\prime} 16^{\prime \prime} \mathrm{S}, 115^{\circ} 39^{\prime} 12^{\prime \prime} \mathrm{E}, 11$ Feb 2011, A.A.E. Williams; Binningup, 33 09' 24" S, $115^{\circ} 41^{\prime} 19^{\prime \prime}$ E, 21 Feb 2011, A.A.E. Williams; Perth, Kallaroo, Maritana

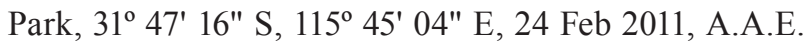
Williams; Perth, Talbot Road Reserve, 31 47' 51" S, $115^{\circ}$ 46' 26" E, 25 Feb 2011, F. Hort and J. Hort; Perth, Mirrabooka Bushland, $31^{\circ} 51^{\prime} 39^{\prime \prime} \mathrm{S}, 115^{\circ} 51^{\prime} 32^{\prime \prime} \mathrm{E}, 02$ Mar 2011, J. Cullity; Perth, Alkimos, Marmion Avenue, $31^{\circ} 37^{\prime} 17^{\prime \prime} \mathrm{S}, 115^{\circ} 41^{\prime} 29^{\prime \prime}$ E, 02 Mar 2011, A.A.E. Williams; Perth, Forrest Road, Bibra Lake, 32 $05^{\prime} 14^{\prime \prime}$ S, $115^{\circ}$ 47' 47" E, 02 Mar 2011, A.A.E. Williams; Perth, Alkimos, 31 37' 19" S, 115 40' 02" E, 02 Mar 2011, R. Browne-Cooper; Preston Beach Conservation Reserve, 
$32^{\circ} 54^{\prime}$ 05" S, $115^{\circ} 39^{\prime}$ 31" E, 02 Mar 2011, C.L. Bishop and M.R. Williams; Wandoo National Park, Crawler Road, 31 58' 53" S, $116^{\circ} 30^{\prime} 57^{\prime \prime}$ E, 02 Mar 2011, A.A.E. Williams, F. Hort and J. Hort; Wandoo National Park, Deefor Road, 31' 59' 26" S, 116 31' 08" E, 02 Mar 2011, A.A.E. Williams, F. Hort and J. Hort; Wandoo National Park, Warrigal Rd, 32 $03^{\prime}$ 28" S, $116^{\circ} 31^{\prime} 50^{\prime \prime}$ E, 02 Mar 2011, A.A.E. Williams, F. Hort and J. Hort; Flynn State Forest, Kent Road, $31^{\circ} 57^{\prime} 49^{\prime \prime} \mathrm{S}, 116^{\circ} 30^{\prime} 48^{\prime \prime} \mathrm{E}$, 02 Mar 2011, A.A.E. Williams, F. Hort and J. Hort; Perth, Errina Road Reserve, 31 $1^{\circ} 49^{\prime} 33^{\prime \prime}$ S, $115^{\circ} 51^{\prime} 32^{\prime \prime}$ E, 03 Mar 2011, C.L. Bishop; Yanchep South, 31 ${ }^{\circ} 34^{\prime}$ 05" S, $115^{\circ}$ 38' 38" E, 03 Mar 2011, R. Browne-Cooper; Perth, Warwick Open Space, $31^{\circ} 50^{\prime} 34^{\prime \prime}$ S, $115^{\circ} 49^{\prime}$ 08" E, 03 Mar 2011, C.L. Bishop; Yarra Road, 6 km $\mathrm{N}$ of Brookton Hwy, $32^{\circ} 10^{\prime} 32^{\prime \prime} \mathrm{S}, 116^{\circ} 26^{\prime} 03^{\prime \prime} \mathrm{E}, 04$ Mar 2011, A.A.E. Williams; Perth, Landsdale Reserve, $31^{\circ}$ 49' 07" S, $115^{\circ} 50^{\prime}$ 52" E, 04 Mar 2011, A.A.E. Williams; Wandoo National Park, Gunappin Ridge, $32^{\circ} 06^{\prime} 15^{\prime \prime} \mathrm{S}, 116^{\circ} 34^{\prime} 36^{\prime \prime} \mathrm{E}, 07$ Mar 2011, F. Hort and J. Hort; Wandoo National Park, Catchment Rd, 32 $06^{\prime}$ 15" S, 116 34' 36" E, 07 Mar 2011, F. Hort and J. Hort; Yanchep, Pipidinny Road, $31^{\circ} 33^{\prime} 51^{\prime \prime}$ S, $115^{\circ} 40^{\prime}$ 50" E, 07 Mar 2011, A.A.E. Williams; Kalbarri National Park, $27^{\circ} 46^{\prime} 25^{\prime \prime}$ S, $114^{\circ} 07^{\prime}$ 30" E, 10 Mar 2011, M.R. Williams, C.L. Bishop and T. Gamblin; Kalbarri Town site, $27^{\circ} 44^{\prime} 15^{\prime \prime} \mathrm{S}, 114^{\circ} 08^{\prime}$ 48" E, 10 Mar 2011, M.R. Williams, C.L. Bishop and T. Gamblin; Port Kennedy, $32^{\circ} 21^{\prime} 48^{\prime \prime}$ S, $115^{\circ} 45^{\prime} 56^{\prime \prime}$ E, 16 Mar 2011, G. Harewood and S. Paul; Wanagarren Nature Reserve, $30^{\circ} 47^{\prime} 36^{\prime \prime} \mathrm{S}$, $115^{\circ} 13^{\prime} 43^{\prime \prime}$ E, 18 Mar 2011, A.A.E. Williams; Gregory,

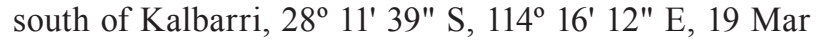
2011, M.R. Williams; Murchison House Station, $27^{\circ} 41^{\prime}$ 55" S, $114^{\circ} 09^{\prime}$ 43" E, 22 Mar 2011, A.A.E. Williams and M.R. Williams; Gibbs Forest, Watershed Road, $32^{\circ}$ 25' 58" S, 116² 24' 24" E, 11 Feb 2012, A.A.E. Williams and E.P. Williams; Brookton Highway, Beraking Pool Rd, 32 $12^{\prime} 41^{\prime \prime} \mathrm{S}, 116^{\circ} 21^{\prime} 56^{\prime \prime}$ E, 15 Feb 2012, A.A.E. Williams; Gibbs Forest, Millars Log Road, 32 24' 24" S, $116^{\circ} 24^{\prime} 01^{\prime \prime}$ E, 17 Feb 2012, A.A.E. Williams; Two Rocks, north of Perth, 31 $21^{\circ} 16^{\prime \prime} \mathrm{S}, 115^{\circ} 37^{\prime} 48^{\prime \prime} \mathrm{E}, 23$ Feb 2012, C.L. Bishop and M.R. Williams; Wilbinga North Coast, 31 24' 46" S, 115 33' 22" E, 23 Feb 2012 , T. Gamblin; Ledge Point Transect $1,30^{\circ} 05^{\prime} 47^{\prime \prime} \mathrm{S}, 115^{\circ}$ 23' 35" E, 27 Feb 2012, A.A.E. Williams and M.R. Williams; Wanagarren Nature Reserve, (West), 30 47' 02" S, 115 12' 28" E, 01 Mar 2012, A.A.E. Williams and M.R. Williams; Wanagarren Nature Reserve, (East), 30 47' 20" S, 115 16' 03" E, 01 Mar 2012, C.L. Bishop and T. Gamblin; Ledge Point Transect 2, 30 06' 22" S, 115² 23' 11" E, 02 Mar 2012, A.A.E. Williams and M.R. Williams; Bullsbrook, Smith Road, 31 ${ }^{\circ} 38^{\prime}$ 59" S, $116^{\circ} 03^{\prime} 15^{\prime \prime}$ E, 02 Mar 2012, A.A.E. Williams; Bullsbrook, Kimberley Road, 31 39' 27" S, $116^{\circ} 02^{\prime}$ 05" E, 02 Mar 2012, A.A.E. Williams; Perth, Marangaroo

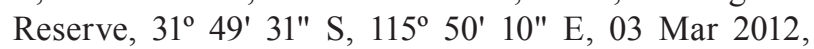
A.A.E. Williams; Perth, Pinnaroo Memorial Park, $31^{\circ} 47^{\prime}$ 51" S, $115^{\circ} 46^{\prime} 26^{\prime \prime}$ E, 03 Mar 2012, A.A.E. Williams; Jurien Bay Transect 1, 30 $17^{\circ} 34^{\prime \prime}$ S, $115^{\circ} 04^{\prime}$ 13" E, 08 Mar 2012, M.R. Williams and C.L. Bishop; Wandoo National Park, $32^{\circ} 12^{\prime} 5^{\prime \prime}$ S, $116^{\circ} 34^{\prime} 16^{\prime \prime}$ E, 08 Mar 2013, F. Hort and J. Hort; Wandoo National
Park, Catchment Rd, $32^{\circ} 06^{\prime} 47^{\prime \prime} \mathrm{S}, 116^{\circ} 37^{\prime} 17^{\prime \prime} \mathrm{E}, 08$ Mar 2013, F. Hort and J. Hort; Wandoo National Park, $32^{\circ} 06^{\prime}$ 47" S, $116^{\circ} 37^{\prime}$ 34" E, 09 Mar 2013, A.A.E. Williams, F. Hort and J. Hort; Wandoo National Park, $32^{\circ} 06^{\prime} 06^{\prime \prime} \mathrm{S}, 116^{\circ} 39^{\prime}$ 24" E, 09 Mar 2013, A.A.E. Williams, F. Hort and J. Hort; Nilgen Nature Reserve, Transect 3, 30 56' 27" S, $115^{\circ} 19^{\prime}$ 05" E, 12 Mar 2012, A.A.E. Williams and M.R. Williams; Jurien Bay, Transect 2, 30 $18^{\circ}$ '13" S, $115^{\circ} 04^{\prime} 18^{\prime \prime}$ E, 13 Mar 2012, C.L. Bishop and T. Gamblin; Port Denison, 29 $19^{\prime} 06^{\prime \prime}$ S, $114^{\circ} 56^{\prime} 52^{\prime \prime}$ E, 14 Mar 2012, M.R. Williams and C.L. Bishop; Seabird, N of Perth, $31^{\circ} 16^{\prime} 56^{\prime \prime} \mathrm{S}, 115^{\circ} 26^{\prime} 45^{\prime \prime}$ E, 23 Mar 2012, A.A.E. Williams and M.R. Williams; Perth, Paloma Park, 31 49' 59" S, $115^{\circ} 51^{\prime}$ 08" E, 17 Mar 2013, A.A.E. Williams; Jurien Bay, North Shore, $30^{\circ} 13^{\prime} 22^{\prime \prime} \mathrm{S}, 115^{\circ} 01^{\prime}$ 00" E, 20 Mar 2013, A.A.E. Williams and M.R. Williams; Perth, Montrose Park, $31^{\circ} 50^{\prime} 38^{\prime \prime} \mathrm{S}, 115^{\circ} 51^{\prime} 12^{\prime \prime} \mathrm{E}, 22$ Mar 2013, A.A.E. Williams; Coolimba Road, $10 \mathrm{~km} \mathrm{~N}$ of Leeman, 29 $51^{\prime}$ 15" S, $114^{\circ}$ 59' 09" E, 30 Mar 2013, A.A.E. Williams; Cape Burney, $9 \mathrm{~km} \mathrm{~S}$ of Geraldton, $28^{\circ} 52^{\prime} 02^{\prime \prime} \mathrm{S}, 114^{\circ}$ 38' 13" E, 07 Apr 2013, A.A.E. Williams and M.R. Williams; Crowther Rd, S of Geraldton, $28^{\circ} 55^{\prime}$ 02" S, $114^{\circ} 40^{\prime}$ 59" E, 08 Apr 2013, A.A.E. Williams; Wandoo National Park, Korner Road, $32^{\circ} 08^{\prime} 31^{\prime \prime}$ S, $116^{\circ} 30^{\prime} 22^{\prime \prime}$ E, 03 Mar 2015, A.A.E. Williams; Perth, Brian Burke

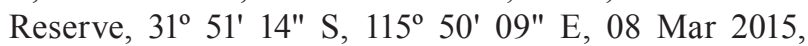
A.A.E. Williams.

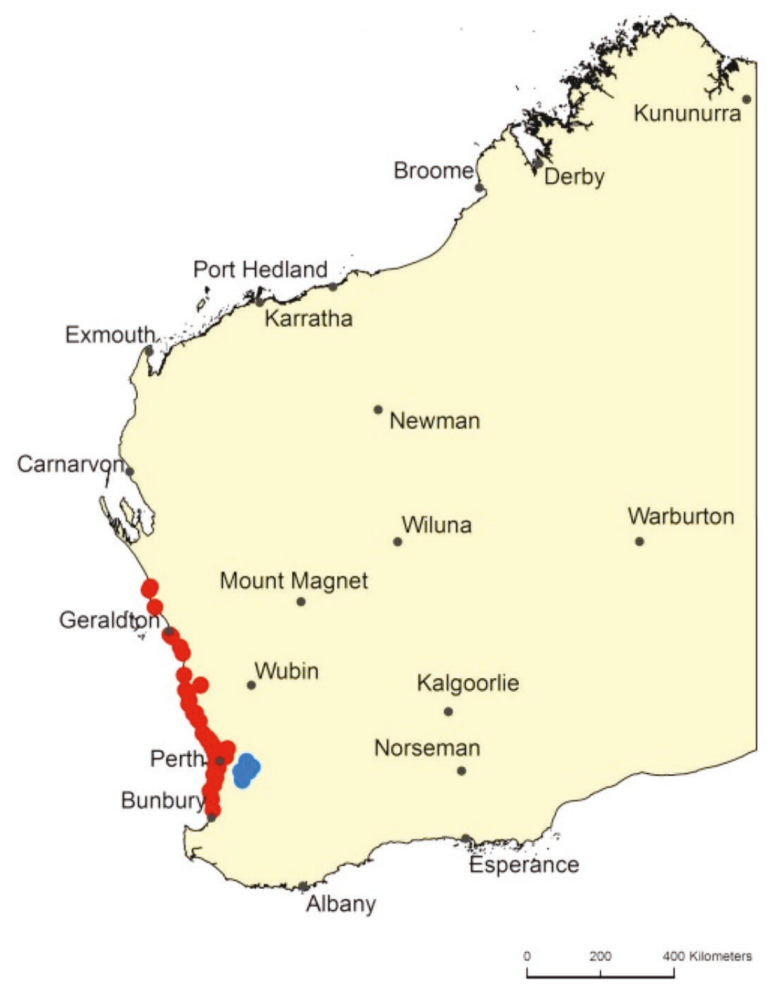

FIGURE 39 Map of Western Australia showing distribution of Synemon gratiosa. Blue dots represent hybrid populations between S. gratiosa and inland sister species $S$. jcaria. 


\section{Synemon jcaria R. Felder 1874 (Claret Sun-moth)}

Figure 40

\section{BRIEF DESCRIPTION}

Synemon jcaria is noticeably larger than S. gratiosa, though there is some size overlap. The upper side of the forewing is variably patterned with grey, brown, blackish, and whitish markings. Males are smaller than females, with distinctly pointed rather than rounded forewings. In both sexes, the upper side of the hind
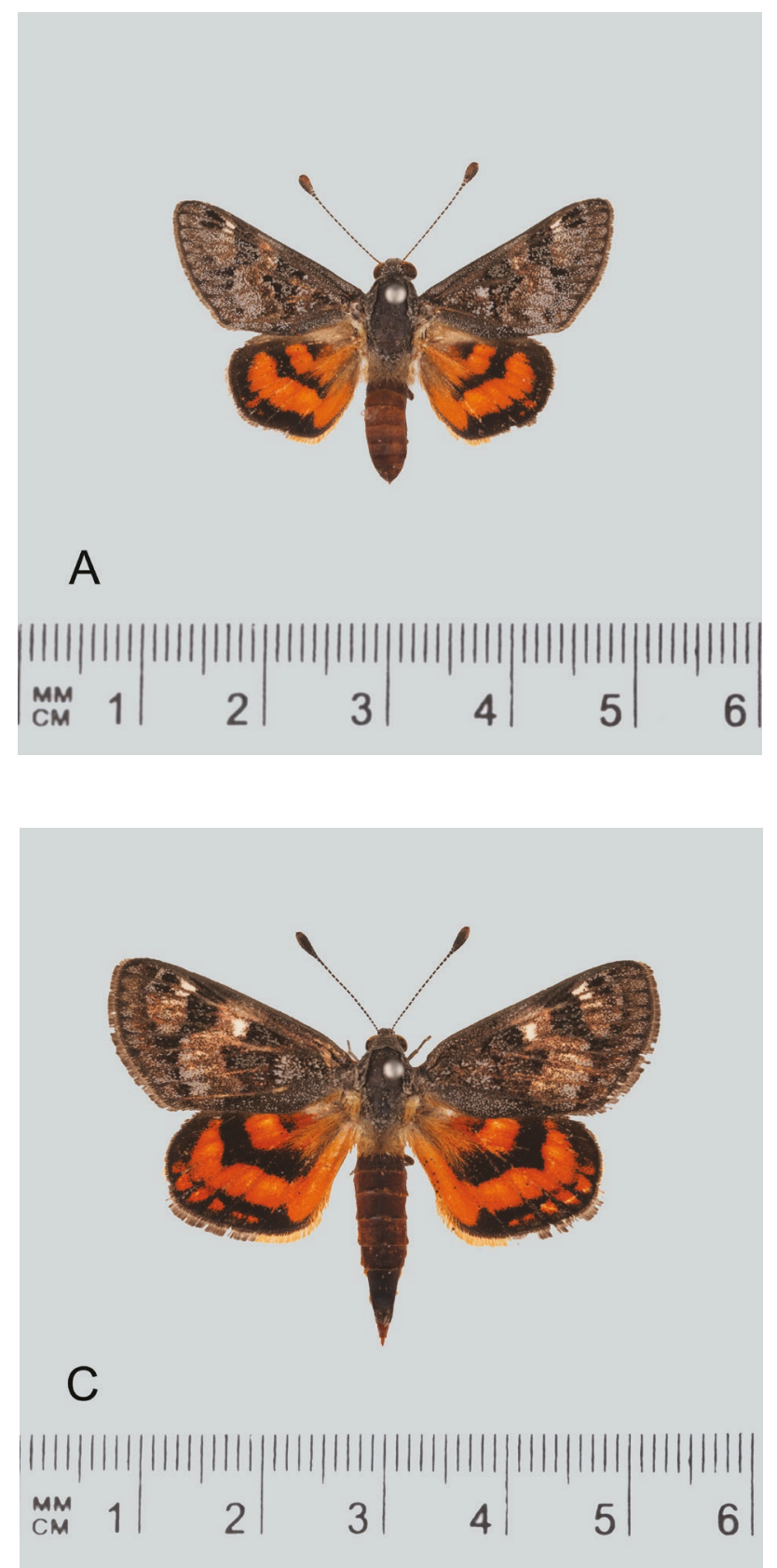

wing is orange, with a blackish border, and invariably with a partial or complete black curved central band. The underside is orange with extensive black markings and some white spotting.

Note: Although the naming of this species is generally credited to R. Felder 1874, the first mention of the name 'Synemon icaria', with an illustration of the sun-moth, but without a description, (nomen nudum), is found in Felder C. et al. (1864). (Leonie Samuelsson, WAM Librarian, personal communication, 3 December 2015). The common
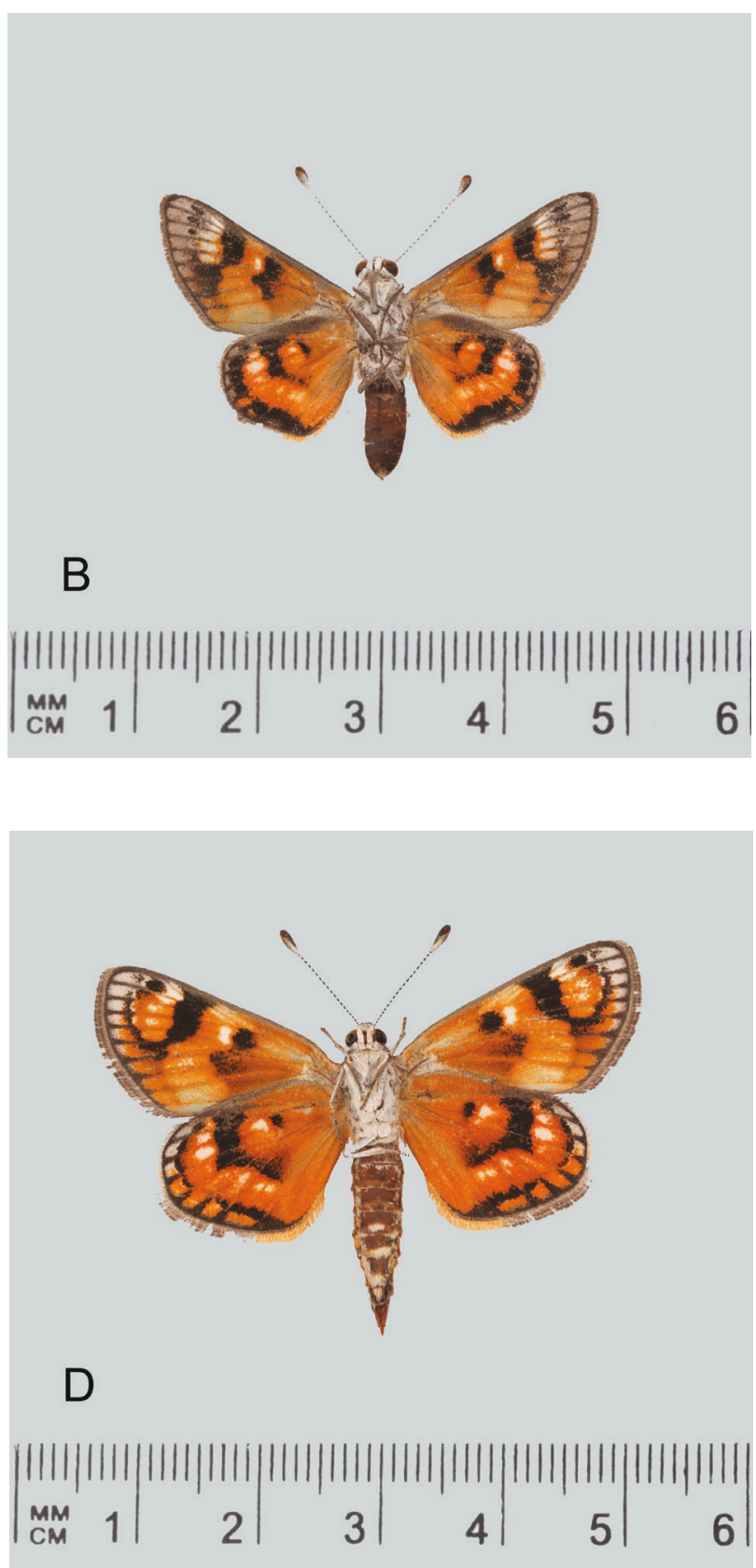

FIGURE 40 Synemon jcaria. A, ô Dorsal; B, ô Ventral (C2910) Western Australia, Namelkatchem Nature Reserve (WAM); C, o Dorsal; D, o Ventral (C2309) Western Australia, Drummond Nature Reserve (WAM). (Photos: Brian Hanich, Western Australian Museum.) 
name Claret Sun-moth is used for Western Australian S. jcaria (Williams A. et al. 2012, Williams and Williams 2013ab). In Victoria and South Australia, the accepted common name is Reddish-orange Sunmoth (Douglas 2007). Recent genetic analysis shows that Western Australian and Victorian S. jcaria are quite well separated genetically (M.R. Williams, personal communication, 2016) (unpublished data), but it is too early to predict whether western and eastern populations are separate species. The level of genetic variation within the eastern populations will first need to be known. At this stage the common name Claret Sun-moth is retained.

\section{DISTRIBUTION}

Synemon jcaria has a predominantly inland distribution in Western Australia. Our recent records have greatly extended its known range and documented its occurrence in many Wheatbelt localities. In the semiarid zone $S$. jcaria has been recorded at Charles Darwin Reserve in the north and near the Menzies-Evanston Road in the east. Along the south coast the species has recently been recorded in Cape Arid National Park. Synemon jcaria populations located by F. and J. Hort from sites in the western parts of its range are in close proximity to areas in the Jarrah (Eucalyptus marginata) forest east of Perth where there appears to be hybridisation between this species and $S$. gratiosa (Gamblin et al. 2011, Williams M. 2012). (See blue dots on S. gratiosa distribution map, Figure 39). Synemon jcaria is also recorded from South Australia, Victoria and New South Wales, though recent studies indicate that the eastern and Western Australian populations are genetically distinct from one another (see Discussion, this paper).

\section{LARVAL FOOD PLANT}

The larval food plant is Scented Mat-rush Lomandra effusa (Lindl.) Ewart. This tussock plant has stiff, long, narrow strap-like leaves with finely pointed bifurcate leaf tips (Williams and Williams 2013a).

\section{HABITAT}

Synemon jcaria is always found in the vicinity of its mat-rush larval food plant, which typically grows in open eucalyptus woodlands and mallee shrublands, or on low inland sand dunes adjacent to inland salt lakes.

\section{BEHAVIOUR AND FLIGHT PERIOD}

This is a small, fast flying sun-moth. Males set up territories in open areas close to the larval food plant. They settle on prominent perches, often fallen sticks or plant stems, and from these vantage points wait for passing unmated females. Rival males which enter

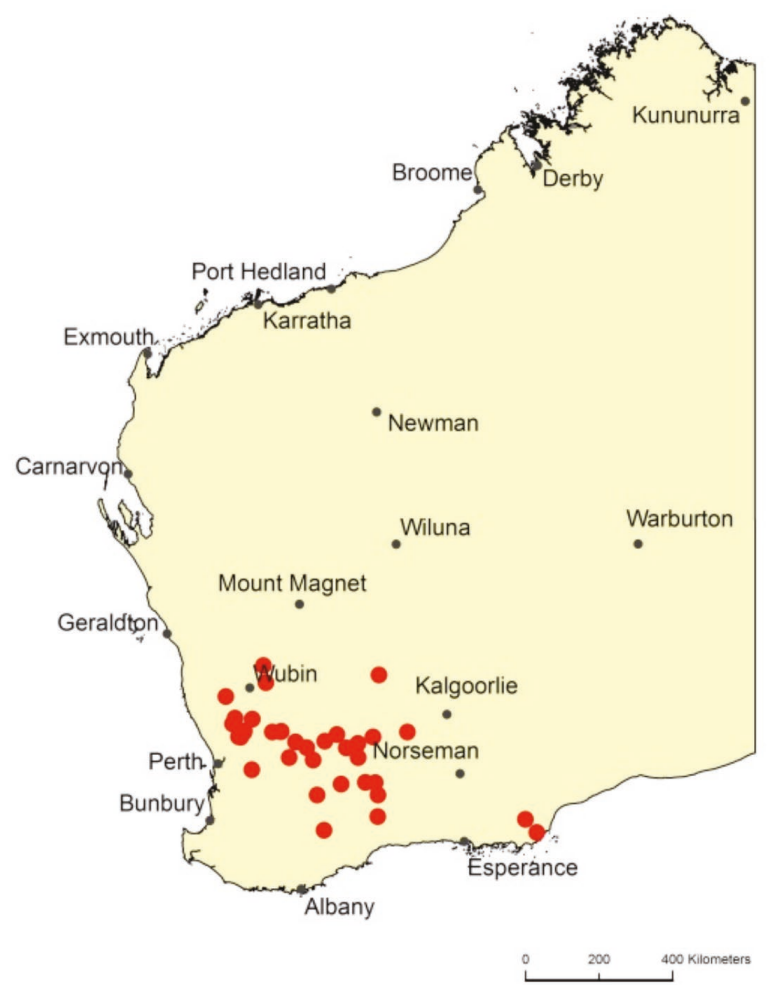

FIGURE 41 Map of Western Australia showing distribution of Synemon jcaria.

the territory are immediately challenged and forced to retreat. Females are less frequently seen. Having mated, they depart and search out suitable larval food plants to lay their eggs. They deposit one egg at a time in the soil alongside the stem of the larval food plant, by means of a retractable ovipositor. The flight period is January to March; the peak flying time is generally mid February.

\section{CONSERVATION STATUS}

Not threatened. In Western Australia this taxon is widespread but local, and moderately common in some places. It is well represented in national parks and nature reserves. There are seven historical and 31 recent records.

\section{HISTORICAL RECORDS}

New Holland, Swan River, location and date not recorded, collector unknown $(\mathrm{BMNH}) ; 37 \mathrm{~km} \mathrm{~S}$ of Lake Cronin, 32 43' 00" S, $119^{\circ} 46^{\prime} 00^{\prime \prime}$ E, 23 Jan 1975, K.T. Richards (DAFC); E of Hyden, $32^{\circ}$ 27' 00" S, $118^{\circ} 52^{\prime}$ 00" E, 15 Feb 1985, R.W. Hay;

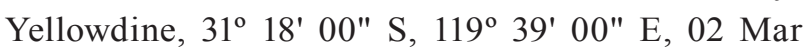
1990, R.W. Hay; Sheoaks Hill, W of Israelite Bay, $33^{\circ} 37^{\prime} 48^{\prime \prime}$ S, 123 39' 36" E, 07 Jan 1993, E.D. Edwards and E.S. Nielsen; $60 \mathrm{~km} \mathrm{E}$ of Hyden, $32^{\circ} 24^{\prime} 00^{\prime \prime} \mathrm{S}, 119^{\circ} 27^{\prime} 00^{\prime \prime} \mathrm{E}, 31$ Jan 1993, E.D. 
Edwards, E.S. Nielsen; $78 \mathrm{~km}$ E of Hyden, $32^{\circ} 25^{\prime}$ 00" S, 119² 42' 00" E, 10 Feb 1993, M.R. Williams, R.W. Hay.

\section{RECENT RECORDS}

Charles Darwin Reserve, 29 $33^{\circ} 29^{\prime \prime} \mathrm{S}, 116^{\circ} 57^{\prime}$ 54" E, 05 Mar 2009, A.A.E. Williams and M.R. Williams; Hopkins Nature Reserve, 32 ${ }^{\circ} 43^{\prime} 14^{\prime \prime}$ S, $118^{\circ} 16^{\prime}$ 39" E, 15 Feb 2010, A.A.E. Williams; Chinocup Nature Reserve, $33^{\circ} 34^{\prime} 38^{\prime \prime}$ S, $118^{\circ} 26^{\prime}$ 56" E, 16 Feb 2010, A.A.E. Williams; Durocoppin Nature Reserve, $31^{\circ} 25^{\prime} 13^{\prime \prime}$ S, $117^{\circ} 45^{\prime} 09^{\prime \prime}$ E, 20 Feb 2010, A.A.E. Williams; Wyalkatchem Golf Course, $31^{\circ} 10^{\prime} 14^{\prime \prime} \mathrm{S}, 117^{\circ} 23^{\prime} 56^{\prime \prime}$ E, 20 Feb 2010, A.A.E. Williams; Petrudor Rocks, 30 51' 43" S, $116^{\circ}$ 41' 31" E, 01 Mar 2010, A.A.E. Williams; Pallarup Nature Reserve, 33 14' 31" S, $119^{\circ} 45^{\prime}$ 49" E, 15 Feb 2011, A.A.E. Williams; $2 \mathrm{~km} \mathrm{~W}$ of Burracoppin, $31^{\circ} 24^{\prime}$ 03" S, 118 28' 06" E, 22 Feb 2011, A.A.E. Williams; Sandford Rock Nature Reserve, $31^{\circ} 14^{\prime} 30^{\prime \prime} \mathrm{S}, 118^{\circ}$ 45' 42" E, 22 Feb 2011, A.A.E. Williams; $1 \mathrm{~km}$ $\mathrm{N}$ of Wyalkatchem, $31^{\circ} 10^{\prime} 15^{\prime \prime} \mathrm{S}, 117^{\circ} 23^{\prime} 27^{\prime \prime} \mathrm{E}$, 22 Feb 2011, A.A.E. Williams; Kellerberrin Road

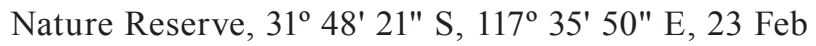
2011, A.A.E. Williams; Calingiri Water Reserve, Bolgart, 31 09' 30" S, $116^{\circ} 29^{\prime}$ 57" E, 11 Feb 2012, F. Hort and J. Hort; Wyening Town site, Bolgart, $31^{\circ} 11^{\prime} 21^{\prime \prime} \mathrm{S}, 116^{\circ} 29^{\prime} 09^{\prime \prime} \mathrm{E}, 11 \mathrm{Feb} 2012$, F. Hort and J. Hort; Julimar Conservation Park, 31 ${ }^{\circ} 17^{\prime} 47^{\prime \prime}$ S, $116^{\circ} 21^{\prime} 23^{\prime \prime}$ E, 13 Feb 2012, F. Hort and J. Hort; Drummond Nature Reserve, $31^{\circ} 18^{\prime} 22^{\prime \prime}$ S, $116^{\circ} 24^{\prime}$ 26" E, 13 Feb 2012, F. Hort and J. Hort; $20 \mathrm{~km} \mathrm{~N}$ of New Norcia, 30 50' 23" S, $116^{\circ} 16^{\prime}$ 09" E, 15 Feb 2012, A.A.E. Williams; $75 \mathrm{~km} \mathrm{E}$ of Yellowdine, $31^{\circ} 10^{\prime} 46^{\prime \prime} \mathrm{S}, 120^{\circ} 29^{\prime} 21^{\prime \prime} \mathrm{E}, 21 \mathrm{Feb}$ 2012, A.A.E. Williams; Wandoo National Park, Qualen Road, $32^{\circ}$ 05' 53" S, 116 40' 42" E, 02 Feb 2013, F. Hort and J. Hort; Namelcatchem Nature Reserve, 31 ${ }^{\circ} 10^{\prime} 52^{\prime \prime}$ S, $117^{\circ} 11^{\prime}$ 02" E, 15 Feb 2013, A.A.E. Williams; Wyalkatchem Nature Reserve, $31^{\circ} 09^{\prime} 43^{\prime \prime}$ S, $117^{\circ}$ 23' 57" E, 25 Feb 2013, A.A.E. Williams; Cape Arid

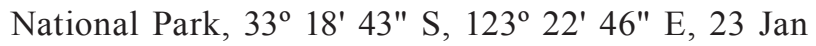
2015, A.A.E. Williams, E.P. Williams; Cramphorne

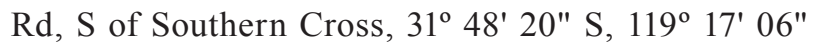
E, 13 Jan 2016, A.A.E. Williams; Dulyalbin Rock Water Reserve, 31 34' 10" S, $118^{\circ} 59^{\prime} 37^{\prime \prime}$ E, 14 Jan 2016, A.A.E. Williams; Frog Rock Nature Reserve, $31^{\circ} 30^{\prime} 05^{\prime \prime}$ S, $119^{\circ} 14^{\prime} 45^{\prime \prime}$ E, 26 Jan 2016, A.A.E. Williams; Wockallarry Nature Reserve, $31^{\circ} 27^{\prime} 37^{\prime \prime}$ S, $119^{\circ} 16^{\prime}$ 50" E, 26 Jan 2016, A.A.E. Williams; Borona Road, ENE of Dulyalbin Rock, $31^{\circ} 33^{\prime} 47^{\prime \prime} \mathrm{S}$, $119^{\circ} 01^{\prime} 29^{\prime \prime}$ E, 26 Jan 2016, A.A.E. Williams; Bruce Rock, Reserve \# 16467, 31 51' 48" S, $118^{\circ} 11^{\circ}$ 02" E, 30 Jan 2016, A.A.E. Williams; New Norcia, Great
Northern Highway, $30^{\circ} 58^{\prime} 58^{\prime \prime}$ S, $116^{\circ} 12^{\prime} 32^{\prime \prime}$ E, 04 Feb 2016, A.A.E. Williams; $2.5 \mathrm{~km} \mathrm{SW}$ of Watheroo, $30^{\circ} 18^{\prime} 55^{\prime \prime} \mathrm{S}, 116^{\circ} 02^{\prime} 32^{\prime \prime}$ E, 06 Feb 2016, A.A.E. Williams; Menzies-Evanston Rd, W of Menzies, $29^{\circ} 47^{\prime} 06^{\prime \prime}$ S, $119^{\circ} 47^{\prime} 46^{\prime \prime}$ E, 15 Feb 2016, A.A.E. Williams; Lake Goorly, $40 \mathrm{~km}$ ENE of Wubin, $29^{\circ} 58^{\prime} 34^{\prime \prime} \mathrm{S}, 117^{\circ} 01^{\prime} 43^{\prime \prime}$ E, 05 Mar 2016, A.A.E. Williams.

\section{Synemon 'Grass-feeding' species group \\ Synemon austera Meyrick 1891 (Sombre Sun-moth)}

Figure 42

\section{BRIEF DESCRIPTION}

Synemon austera is a cryptically coloured, medium sized sun-moth. In the male, the ground colour on the upper side of the forewing is dull grey and brown, with a blurred white central spot and post-median band. The hind wing is blackish-brown above, with a large wedge-shaped cream marking extending inwards from the termen to a median point near the dorsum. The female's forewing is grey-brown on the upper side, with a small blurred central white spot. The hind wing upper side is blackish-brown, with cream-brown markings. In both sexes the underside is similar: the basal area dark blackish-brown, with the outer portion of the forewing pale orange-brown; females have a subapical band of dark brown elongate spots at the apex of the forewing.

\section{DISTRIBUTION}

Synemon austera is is known only from Carnarvon and the Minilya River, in the Gascoyne region of Western Australia (Figure 43).

\section{LARVAL FOOD PLANT}

The larval food plant is a tussock-forming form of Golden Beard Grass Chrysopogon fallax S.T. Blake (E.D. Edwards, personal observation, 1992; A.A.E. Williams, personal observation, 2010).

\section{HABITAT}

The type specimens were collected by Meyrick at Carnarvon 'in a damp place on the plain' (Meyrick 1891). This plain has been degraded over the last 100 years, and attempts to relocate the sun-moths there have been unsuccessful. In recent times the sun-moth has only been found at two localities; a seasonally wet watercourse lined with white-barked Eucalyptus victrix trees near Carnarvon, and at one site alongside the Minilya River. 


\section{BEHAVIOUR AND FLIGHT PERIOD}

This cryptic species flies close to the ground along usually dry seasonal watercourses in the vicinity of its larval food plant. The peak flight period is in mid to late October, with some individuals still active in early November.

\section{CONSERVATION STATUS}

Data deficient - possibly endangered. Synemon austera is only known from two localities in pastoral areas in the Gascoyne region of Western Australia.
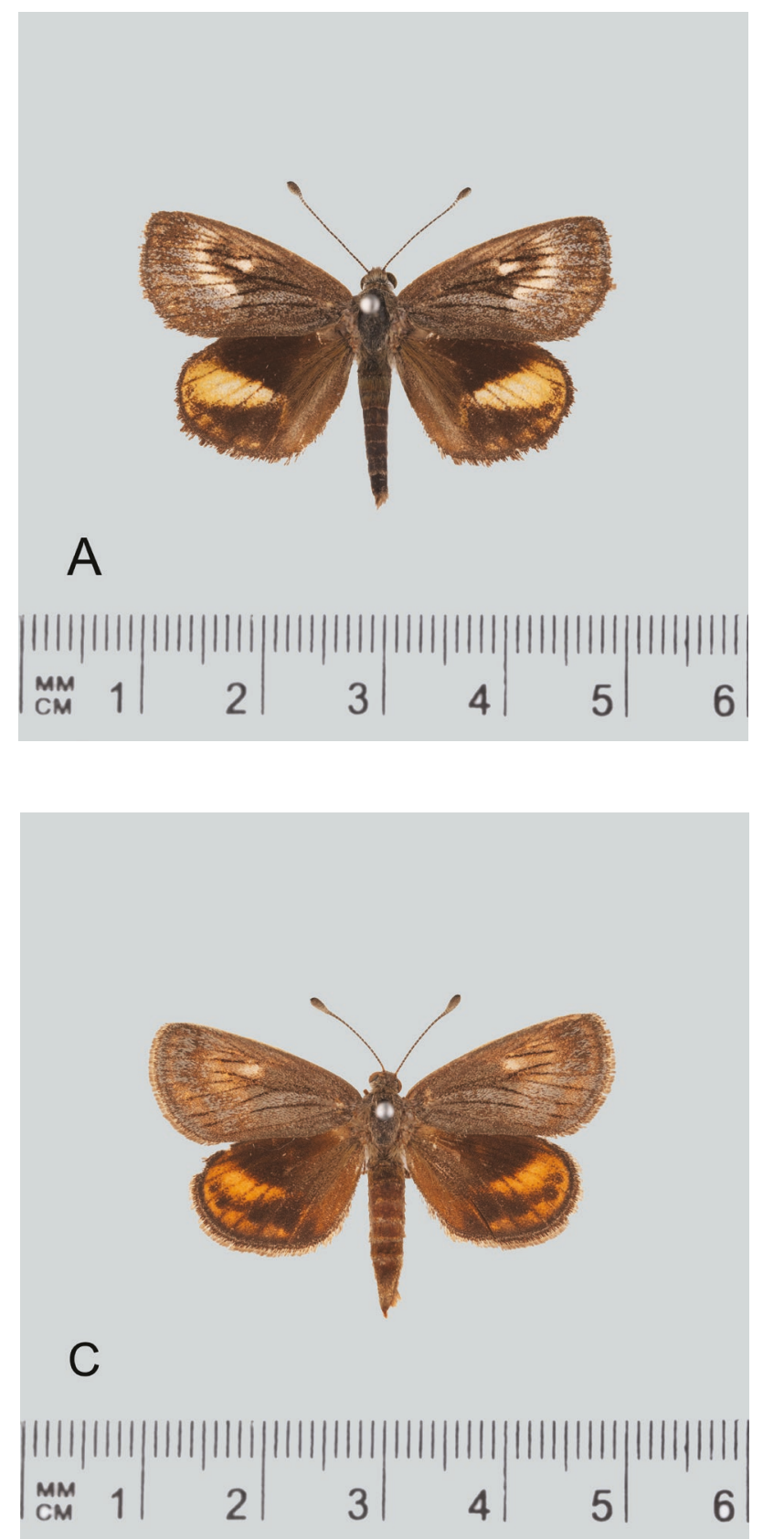

Insufficient surveys have been conducted to determine its conservation status. Known colonies are very local. Damage to the habitat and larval food plant of this rare sun-moth by cattle must be regarded as a serious threat. There are three historical and two recent records.

\section{HISTORICAL RECORDS}

Carnarvon, $24^{\circ} 53^{\prime} 00^{\prime \prime} \mathrm{S}, 113^{\circ} 40^{\prime} 00^{\prime \prime} \mathrm{E}, 23$ Oct 1886, E. Meyrick (BMNH); $9 \mathrm{~km} \mathrm{NE}$ of Carnarvon, $24^{\circ} 49^{\prime} 00^{\prime \prime} \mathrm{S}, 113^{\circ} 43^{\prime} 00^{\prime \prime}$ E, 19-23 Oct 1992, E.D. Edwards and E.S. Nielsen; $1 \mathrm{~km} \mathrm{~S}$ of Minilya River,
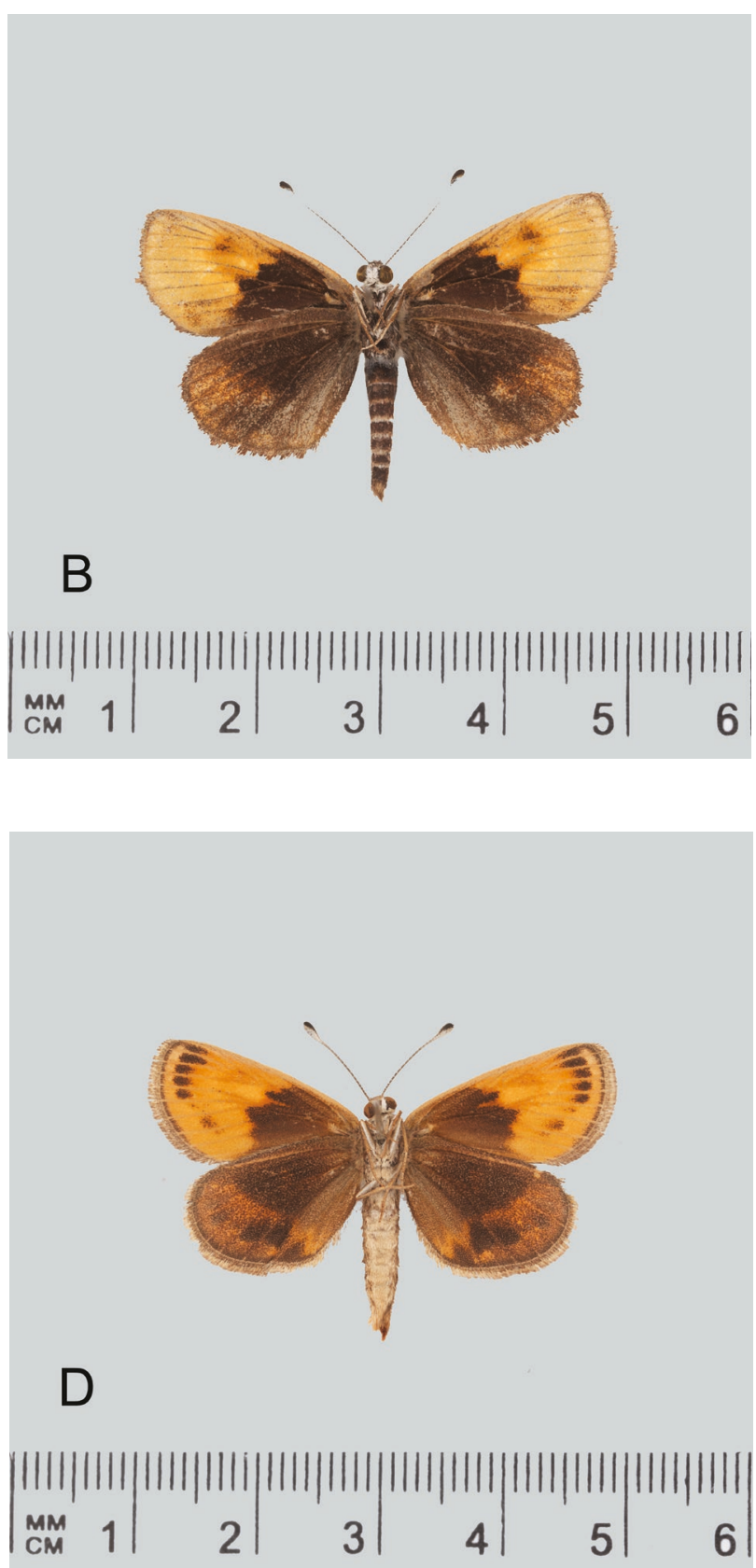

FIGURE 42 Synemon austera. A, ô Dorsal; B, ô Ventral (C0814) Western Australia, Carnarvon (WAM); C, $q$ Dorsal; D, q Ventral (C0817) Western Australia, Carnarvon (WAM). (Photos: Brian Hanich, Western Australian Museum.) 


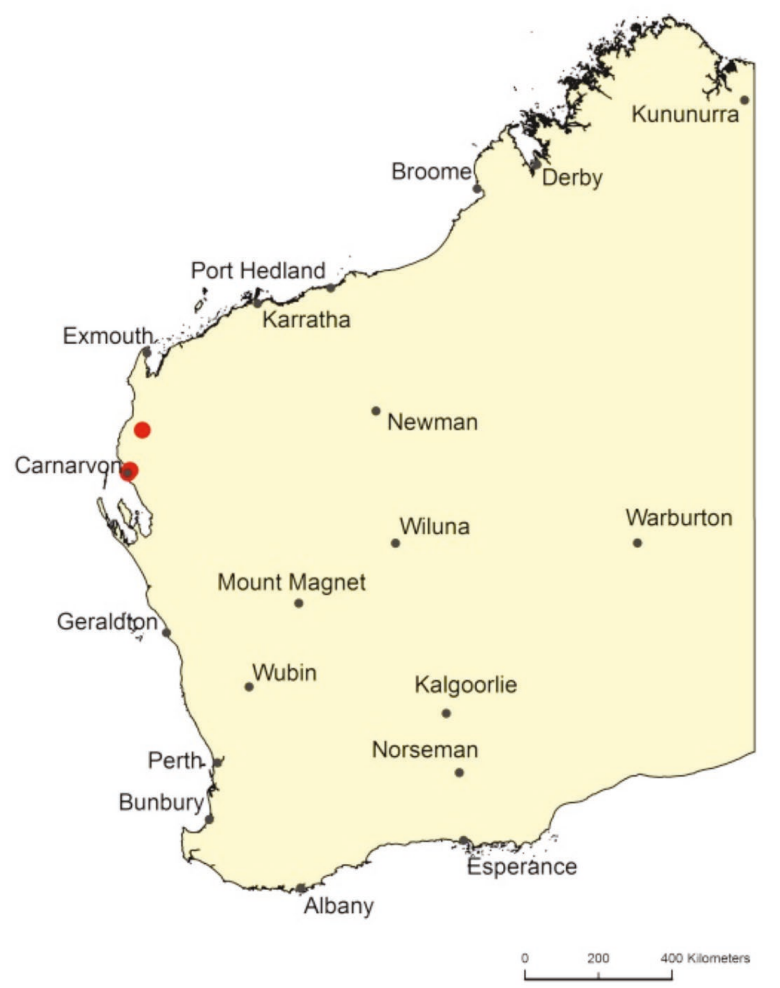

FIGURE 43 Map of Western Australia showing distribution of Synemon austera.

$23^{\circ} 50^{\prime} 00^{\prime \prime} \mathrm{S}, 114^{\circ} 01^{\prime}$ 00" E, 21 Oct 1992, E.D. Edwards and E.S. Nielsen.

\section{RECENT RECORDS}

9 km NE of Carnarvon, $24^{\circ} 48^{\prime} 59^{\prime \prime} \mathrm{S}, 113^{\circ} 43^{\prime} 02^{\prime \prime} \mathrm{E}$, 12 Nov 2009, A.A.E. Williams; 9 km NE of Carnarvon, $24^{\circ} 48^{\prime}$ 59" S, $113^{\circ} 43^{\prime}$ 02" E, 14-15 Oct 2010, A.A.E. Williams.

\section{Synemon brontias Meyrick 1891 (Meyrick's Sun-moth)}

Figure 44

\section{BRIEF DESCRIPTION}

Synemon brontias is a small, nondescript sun-moth. In males the basal half of the upper side of the forewing is grey-brown edged blackish, enclosing a small white median spot near the leading edge of the wing. The outer portion of the forewing is whitish, with a pale grey-brown subapical band merging into a line of small dark subtornal spots. The basal half of the upper side of the hind wing is brownish-black, the outer portion pale cream, with the termen edged grey-brown. On the underside of the forewing the basal third is brownishblack, the outer portion predominantly cream-yellow, with a large contrasting brownish black subcostalpostmedian spot. On the underside of the hind wing the basal two thirds are brownish-black, the outer third patterned pale brown and cream. In the female, the upper side forewing pattern is similar to that of the male, but is generally greyer with less obvious darker markings. The basal half of the hindwing upper side is brownish-black, with a small yellowish discal spot. The outer half is pale brownish yellow, with three or four pale brown subtornal spots. The termen is blackish brown. On the underside, the basal third of the forewing is brown. The outer portion is yellow, with small but distinct brown subcostal-postmedian and subapical spots. The termen is lined with very small brown spots. The basal half of the hindwing is blackish brown, with a clear yellow discal spot. The outer half is brownish yellow, with four or five distinct brown subterminal spots. The outer border is narrowly edged brown. The photo illustrations of $S$. brontias in this paper are of specimens from White Mountains National Park in Queensland, Australia.

\section{DISTRIBUTION}

In Western Australia S. brontias is known from coastal and inland sites in the Gascoyne and Pilbara regions (Figure 45). The type specimens, held in the British Museum of Natural History, were collected near Carnarvon on 26 October 1886 (Meyrick 1891). Another old specimen, also in the British Museum of Natural History, has a locality label 'Sherlock River' but lacks any further information. In October 1995, a specimen which probably belongs to this species was obtained at Cape Range National Park. In September 2005, a further specimen was caught in a Malaise trap on Juna Downs Station in the Pilbara (E.D. Edwards, personal communication, 2010). Another individual was subsequently seen at exactly the same site on 23 September 2011 (A.A.E. Williams, personal observation). Specimens illustrated in this paper from northern Queensland (Figure 44) either belong here, or are very closely related to this species (E.D. Edwards, personal communication, 2015).

\section{LARVAL FOOD PLANT}

The larval food plant is almost certainly Golden Beard Grass Chrysopogon fallax S.T. Blake. Larvae, presumed to be $S$. brontias, have been found in the rhizomes of $C$. fallax at Karijini National Park, $31 \mathrm{~km}$ north-north-west of Juna Downs Station, in similar habitat to that at Juna Downs Station (Williams A. 2011). These larvae have been preserved for phylogenetic examination.

\section{HABITAT}

The original specimens were described as being found 'on the plain' near Carnarvon (Meyrick 1891). At Juna Downs Station the habitat is an alluvial plain beside a shallow creek where Mulga (Acacia aneura) woodland grows over open grassland including $C$. fallax. At Cape 
Range National Park the habitat is a spinifex-dominated rocky slope near a dry range creek bed (A.G. Tomlinson, personal communication, 2005).

\section{BEHAVIOUR AND FLIGHT PERIOD}

Observations at Cape Range National Park and Juna Downs Station indicate that this species is most active in the mornings between 10:00 and 12:00 WST. The adult observed at Juna Downs Station in 2011 flew close to the ground in open areas between scattered dry tussocks of the presumed larval food plant, C. fallax (A.A.E. Williams, personal observation, 2011). At Juna Downs $S$.
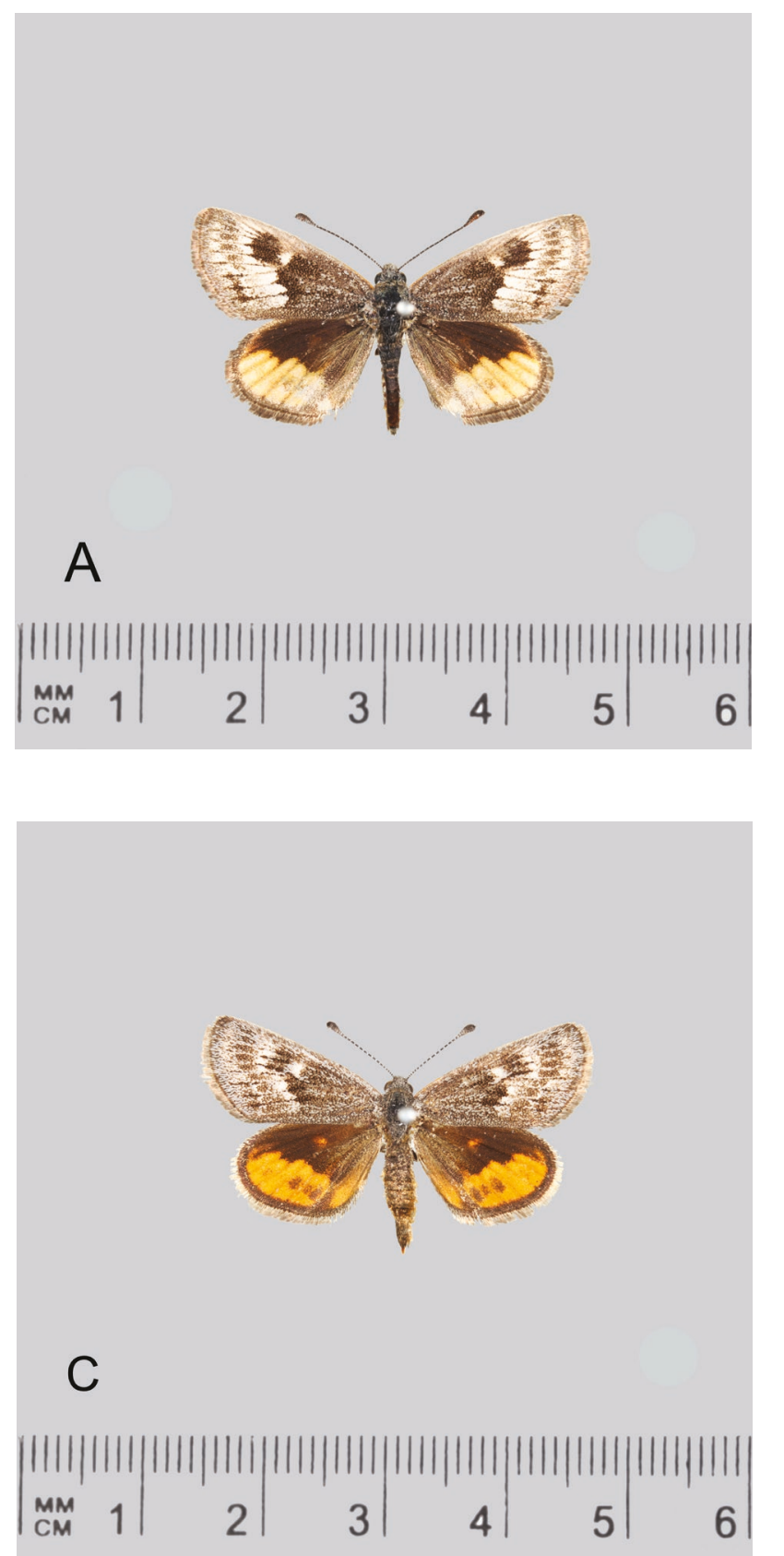

brontias flies in late September, while at Carnarvon and Cape Range it has been recorded in October.

\section{CONSERVATION STATUS}

Data deficient - possibly endangered. Although scanty, the historical records indicate that the species may be widespread across the Gascoyne and Pilbara regions. The paucity of recent records, however, suggests that the species is or has become very rare. Insufficient surveys have been conducted to determine its conservation status accurately. Known colonies are very local. Damage to the habitat and larval food plant
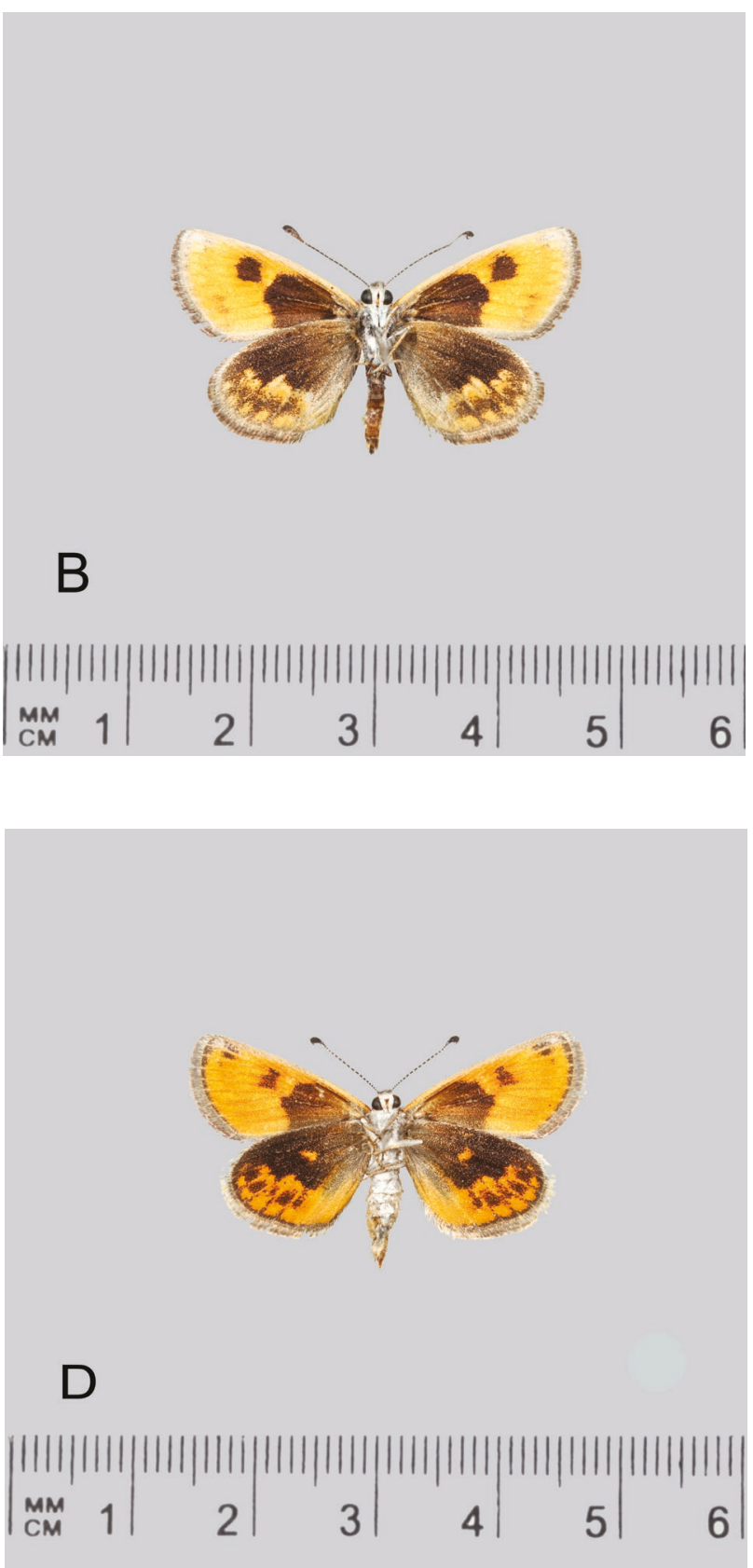

FIGURE 44 Synemon brontias. A, ổ Dorsal; B, ô Ventral (ANIC31052448) Queensland, White Mountains National Park (ANIC); C, o Dorsal; D, q Ventral (ANIC31036144) Queensland, White Mountains National Park (ANIC). (Photos: You Ning Su, CSIRO, Canberra.) 


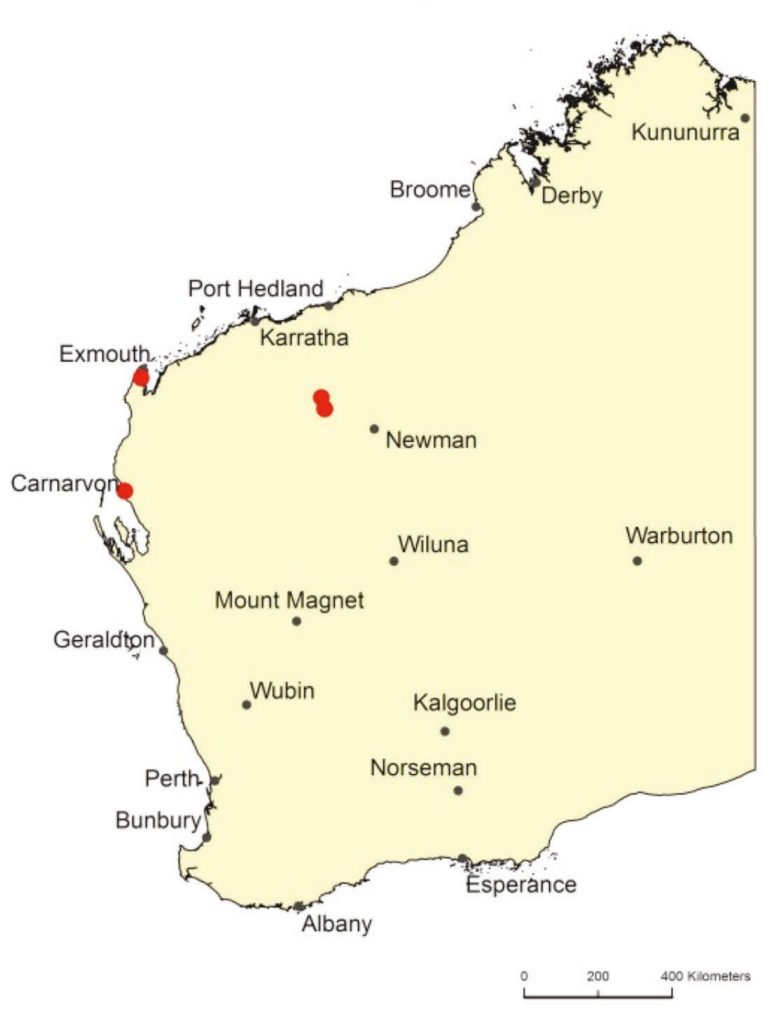

FIGURE 45 Map of Western Australia showing distribution of Synemon brontias.

of this rare sun-moth by cattle or mining activity, must be regarded as serious threats. There are three historical and three recent records.

\section{HISTORICAL RECORDS}

Carnarvon, 24 53' 00" S, 113 40' 00" E, 26 Oct 1886, E. Meyrick (BMNH); Sherlock River, location and date not recorded, collector unknown (BMNH); Cape Range National Park, 22 07' 15" S, 114 03' 49" E, 03 Oct 1995, A.G. Tomlinson (TTC).

\section{RECENT RECORDS}

Juna Downs Station, $22^{\circ} 52^{\prime} 31^{\prime \prime} \mathrm{S}, 118^{\circ} 31^{\prime} 49^{\prime \prime}$ E, 28 Sep 2005, collector unknown; Juna Downs Station (sight record), 22 52' 29" S, $118^{\circ}$ 31' 52" E, 23 Sep 2011, A.A.E. Williams; Karijini National Park (larvae), $22^{\circ} 35^{\prime}$ 52" S, $118^{\circ} 27^{\prime} 02^{\prime \prime}$ E, 24 Sep 2011, A.A.E. Williams.

\section{Synemon nais Klug 1850 (Orange Sun-moth)}

Figure 46

\section{BRIEF DESCRIPTION}

This is a very small sun-moth, with rounded wings in both sexes. The upper side of the forewing is variable. The base colour is brownish-grey, patterned with paler grey and blackish markings and a small white central spot. The basal third of the hind wing is blackish-brown and encloses an orange discal spot. The remainder of the hind wing is orange; the outer margin has a series of blackish-brown spots which are often fused. In males, the underside of both wings is orange with brown and blackish-brown markings. Females are similar, but more extensively orange than males.

\section{DISTRIBUTION}

In Western Australia $S$. nais occurs on the Nullarbor Plain. This taxon also occurs in South Australia and Victoria. In Western Australia, the species has been recorded $70 \mathrm{~km}$ west of Caiguna, $12 \mathrm{~km}$ east of Madura, and $56 \mathrm{~km}$ west of Mundrabilla (ANIC Castniidae database). Intermediate sites have recently been located, between Madura and Mundrabilla, and west of Caiguna (Figure 47).

\section{LARVAL FOOD PLANT}

The larval food plants are grasses (Poaceae) and in South Australia include Bristly Wallaby Grass Austrodanthonia setacea (R. Br.) H.P. Linder, Desert Spear Grass Austrostipa eremophila (Reader) S.W.L. Jacobs and J. Everett, and Rough Spear Grass Austrostipa scabra (Lindl.) S.W.L. Jacobs and J. Everett (Grund 2011). At Caiguna, in Western Australia, the larval food plant is Austrostipa nitida (Summerh. and C.E. Hubb.) S.W.L. Jacobs and J. Everett.

\section{HABITAT}

In the western part of the Nullarbor Plain, between Balladonia and Madura, the habitat is $A$. nitida grassland with small scattered patches of mallee / shrubland. East of Madura, below the escarpment, this sun-moth occurs in areas of extensive low saltbush over small grass tussocks. In October 2013 most of these tussock grasses were found to be dry, and adult sun-moths were only encountered along roadside drainage ditches, where sufficient water enabled the grasses to produce new growth.

\section{BEHAVIOUR AND FLIGHT PERIOD}

These sun-moths become active when daytime temperatures reach $24-25^{\circ} \mathrm{C}$. On days of intermittent sunshine, they fly during sunny spells but remain still when cloud cover forms. Males set up territories, often in open areas within the grassland habitat. At sites where the sun-moths are locally common, combat flights between rival males are frequent (A.A.E. Williams, personal observation, 2013). Similar territorial behaviour has been recorded on the Eyre Peninsula, in South Australia (Grund 2011). In Western Australia, the flight period begins in early September and peaks in late September to early October. In South Australia and Victoria this sun-moth flies in October and November (Grund 2011; Douglas 2012). 


\section{CONSERVATION STATUS}

Data deficient. In Western Australia, S. nais is known from a few isolated colonies across the Nullarbor Plain. Suitable-looking habitat is widespread, but insufficient surveys have been conducted to accurately determine the species' occurrence and distribution. In coastal South Australia it is considered local or rare (Grund 2011), with frequent fires being regarded as a threatening process. In Victoria, S. nais is listed as threatened under the Flora and Fauna Guarantee Act 1988 (Douglas 2004; 2012). There are four historical and seven recent records.

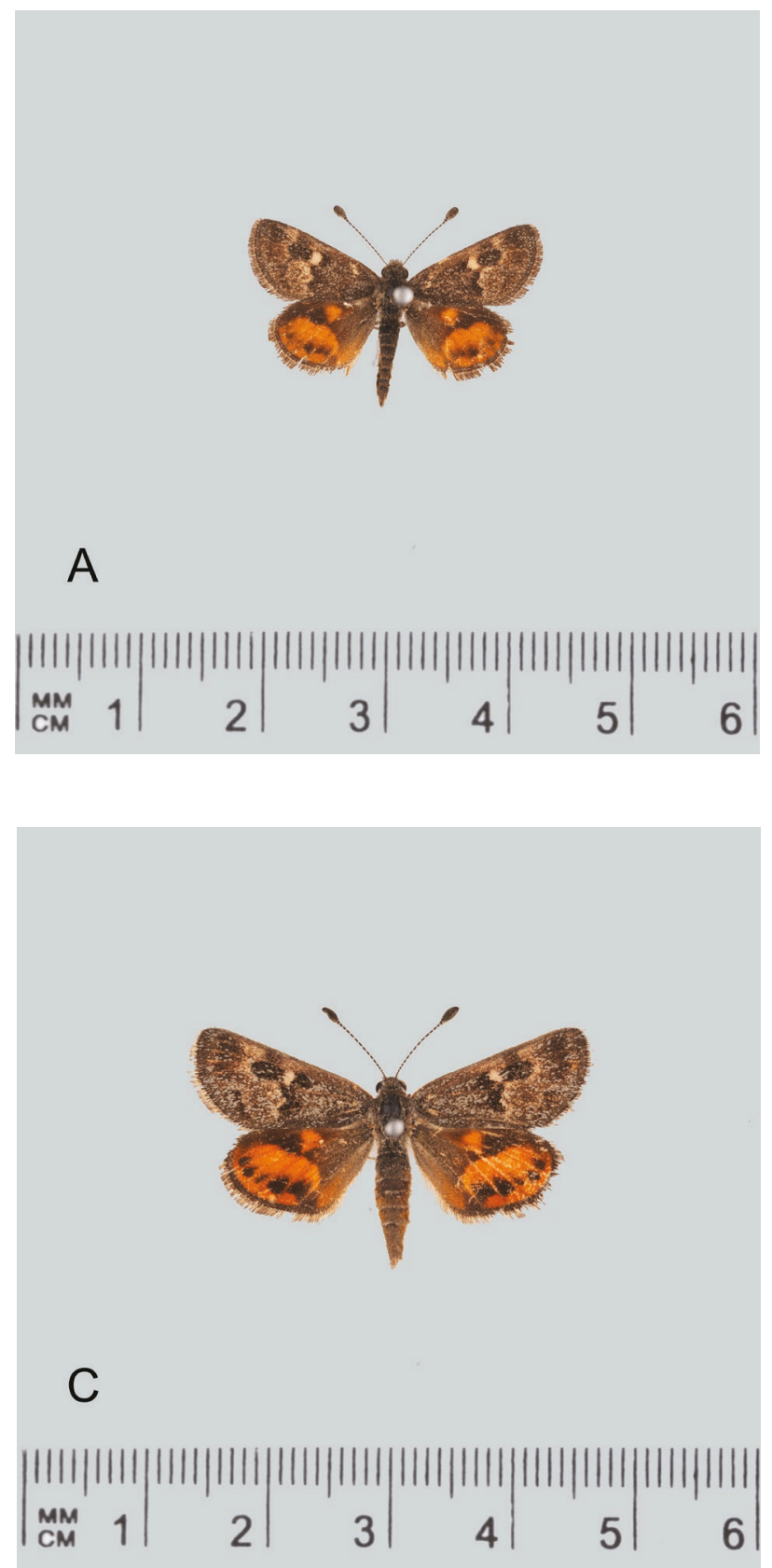

\section{HISTORICAL RECORDS}

New Holland, location and date not recorded, collector unknown (MNHU); $43 \mathrm{mi}$. W by S of Caiguna, $32^{\circ} 21^{\prime}$ 00" S, $127^{\circ} 46^{\prime} 00^{\prime \prime}$ E, 14 Oct 1968, Britton, Upton and Balderson; $13 \mathrm{mi}$. W by S of Mundrabilla HS, 31 $53^{\circ}$ $00^{\prime \prime} \mathrm{S}, 127^{\circ} 38^{\prime} 00^{\prime \prime} \mathrm{E}, 16$ Oct 1968, Britton, Upton, and Balderson; $12 \mathrm{~km}$ E of Madura, $31^{\circ} 54^{\prime} 00^{\prime \prime} \mathrm{S}, 127^{\circ} 09^{\prime}$ 00” E, 23 Sep 1981, D.C.F. Rentz.

\section{RECENT RECORDS}

$4.4 \mathrm{~km}$ ENE of Caiguna, $32^{\circ} 15^{\prime} 00^{\prime \prime} \mathrm{S}, 125^{\circ} 31^{\prime} 30^{\prime \prime} \mathrm{E}$, 9 Oct 2008, K.L. Dunn (ANIC); $5 \mathrm{~km} \mathrm{~W}$ of Caiguna, $32^{\circ}$
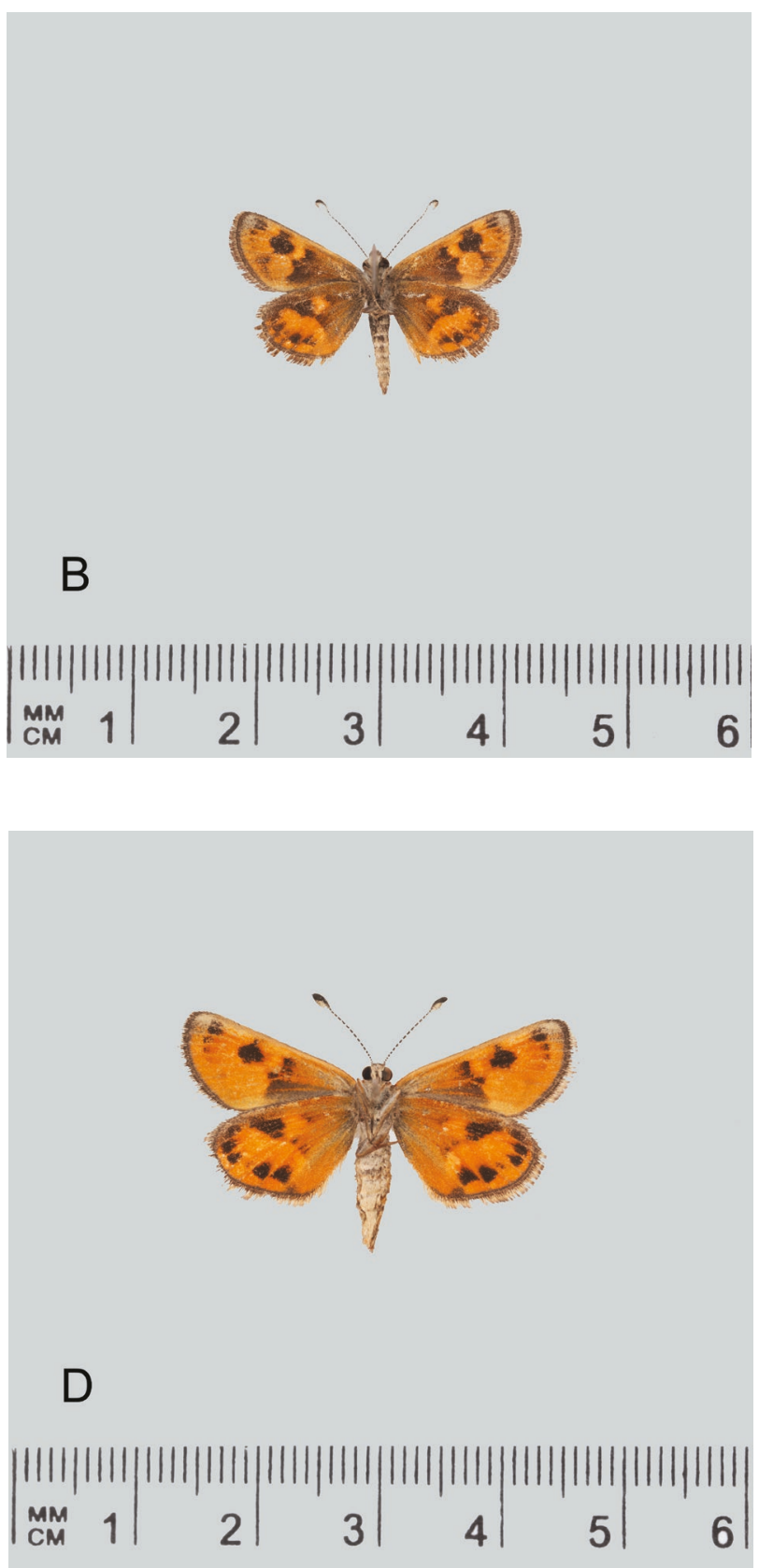


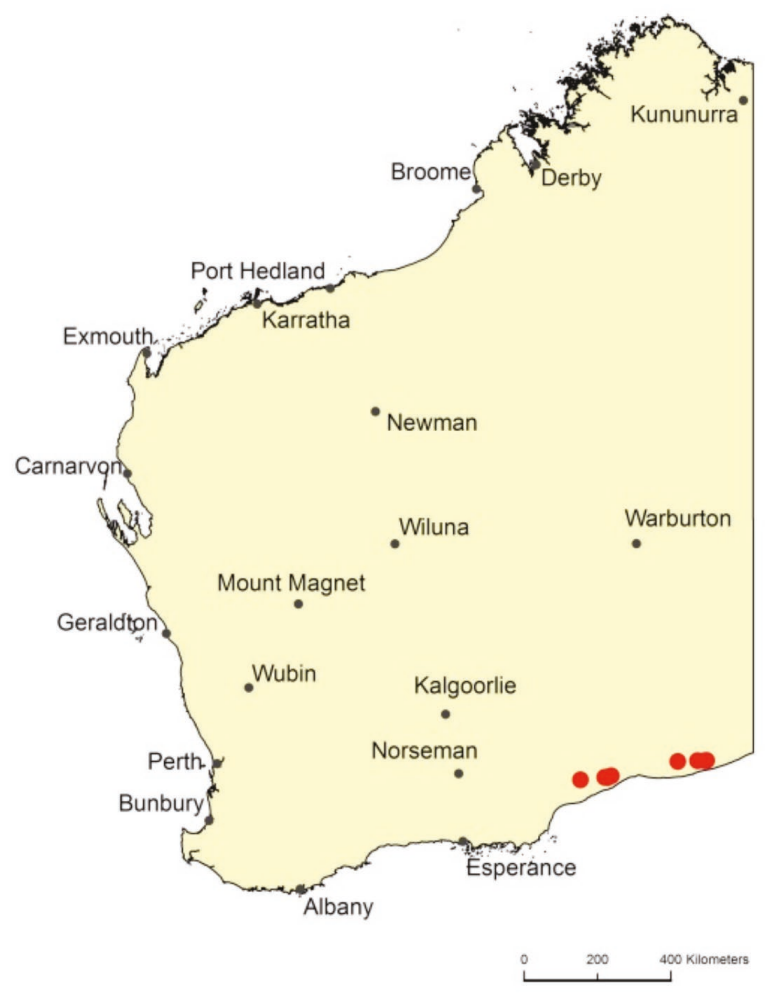

FIGURE 47 Map of Western Australia showing distribution of Synemon nais.

$16^{\prime} 40^{\prime \prime} \mathrm{S}, 125^{\circ} 25^{\prime} 50^{\prime \prime} \mathrm{E}, 24$ Sep 2012, G. Walker; 2 km $\mathrm{S}$ of Caiguna Blowhole, $32^{\circ} 17^{\prime} 37^{\prime \prime} \mathrm{S}, 125^{\circ} 25^{\prime} 54^{\prime \prime} \mathrm{E}, 3$ Oct 2013, A.A.E. Williams; $12 \mathrm{~km} \mathrm{~W}$ of Caiguna, $32^{\circ}$ $17^{\prime} 10^{\prime \prime} \mathrm{S}, 125^{\circ} 21^{\prime} 39^{\prime \prime}$ E, 3 Oct 2013, A.A.E. Williams; $35 \mathrm{~km} \mathrm{~W}$ of Mundrabilla, $31^{\circ} 52^{\prime} 29^{\prime \prime} \mathrm{S}, 127^{\circ} 51^{\prime} 38^{\prime \prime} \mathrm{E}$, 3 Oct 2013, A.A.E. Williams; $40 \mathrm{~km} \mathrm{~W}$ of Mundrabilla, $31^{\circ} 52^{\prime} 51^{\prime \prime} \mathrm{S}, 127^{\circ} 48^{\prime} 40^{\prime \prime}$ E, 3 Oct 2013, A.A.E. Williams; $5 \mathrm{~km} \mathrm{~W}$ of Caiguna, 32 $16^{\prime} 40^{\prime \prime} \mathrm{S} ., 125^{\circ} 25^{\prime} 51^{\prime \prime}$ E.,3-5 Oct 2013,A.A.E. Williams.

\section{Synemon obscurella Westwood 1877 (Western Cryptic Sun-moth)}

Figure 48

\section{BRIEF DESCRIPTION}

Synemon obscurella is a small to medium sized sun-moth, with rounded wings and a wingspan of approximately $35 \mathrm{~mm}$. The upper surface of the forewing is patterned in variable tones of grey and greybrown, and has a small but distinct central white spot. The upper side of the hind wing is dark grey-brown, with extensive paler orange-brown markings. The underside of the forewing is brown, with an orangebrown apical area and postmedian band. The underside of the hindwing is also brown, variably spotted with orange-brown markings. When settled with its wings closed, the white spot on the upper surface of the forewing is visible. Sometimes diminutive specimens are encountered which are much paler. Westwood described an extreme one of these.

\section{DISTRIBUTION}

S. obscurella is a Western Australian endemic. The northernmost record is $26 \mathrm{~km}$ south of Billabong Roadhouse, on the Great Northern Highway. Further south, it has been recorded $10 \mathrm{~km}$ north-east of Eurady Homestead, $26 \mathrm{~km}$ north of Eneabba, at Beverley, and at Hamel. To the south-east it has been recorded as far inland as Wialki, Peak Charles National Park, and Moirs Rock (ANIC Castniidae database). Recent records extend this sun-moth's range southwards and increase the number of known localities in Western Australia's conservation estate (Figure 49).

\section{LARVAL FOOD PLANTS}

The larval food plants are Tussocky Cord-rush Ecdeiocolea monostachya F. Muell., and the tall tussock grass Spartochloa scirpoidea (Steud.) C.E. Hubb (E.D. Edwards, personal communication, 2013).

\section{HABITAT}

Synemon obscurella occurs in shrublands and open eucalyptus woodlands, invariably close to either $E$. monostachya, or the tall tussock grass S. scirpoidea, which is often associated with exposed granite pavement or granite outcrops.

\section{BEHAVIOUR AND FLIGHT PERIOD}

S. obscurella is a cryptic species, its sombre grey and orange-brown colouration making it inconspicuous in flight. Males are generally seen flying round the larval food plants, in search of unmated females. This species has an extended flight period in late spring and summer. In its northernmost localities, it flies in October and November, whereas in southern and inland localities it is on the wing from December to January.

\section{CONSERVATION STATUS}

Not threatened. This species is widespread, locally common, and well represented in the conservation estate. There are nine historical and 26 recent records.

\section{HISTORICAL RECORDS}

Australia, location and date not recorded, collector unknown (HEC); Beverley, 32 $07^{\prime}$ 00" S, 116 56' 00" $\mathrm{E}$, date not recorded, collector unknown; Hamel, $32^{\circ}$ $52^{\prime} 00^{\prime \prime} \mathrm{S}, 115^{\circ} 55^{\prime} 00^{\prime \prime} \mathrm{E}, 15$ Dec 1913, R. Illidge; 5 miles W of Wialki, 30 29' 00" S, $118^{\circ} 02^{\prime}$ 00" E, 04 Dec 1978, M. Powell; Peak Charles National Park, $32^{\circ}$ 53' 00" S, $121^{\circ} 10^{\prime} 00^{\prime \prime}$ E, 01 Jan 1986, G. Daniels and A. Daniels (UQ); $26 \mathrm{~km} \mathrm{~S}$ of Billabong Roadhouse, 
$27^{\circ} 02^{\prime} 00^{\prime \prime} \mathrm{S}, 114^{\circ} 39^{\prime}$ 00" E, 24 Oct 1992, E.D. Edwards and E.S. Nielsen; Moirs Rock NE of Salmon Gums, 320 39' 00" S, $121^{\circ} 25^{\prime}$ 00" E, 11 Jan 1993, E.D. Edwards; $26 \mathrm{~km} \mathrm{~N}$ of Eneabba, $29^{\circ} 35^{\prime} 00^{\prime \prime} \mathrm{S}, 115^{\circ} 16^{\prime}$ 00" E, 24 Nov 1995, T.F. Houston (WAM); 10.5 km NE of Eurardy Homestead, $27^{\circ} 29^{\prime} 24^{\prime \prime}$ S, 114 44' 25" E, 24 Nov 1998, T.F. Houston (WAM).

\section{RECENT RECORDS}

$40 \mathrm{~km} \mathrm{~S}$ of Billabong Roadhouse, 27 10' 28" S, $114^{\circ} 36^{\prime}$ 58" E, 11 Nov 2009, A.A.E. Williams; 80
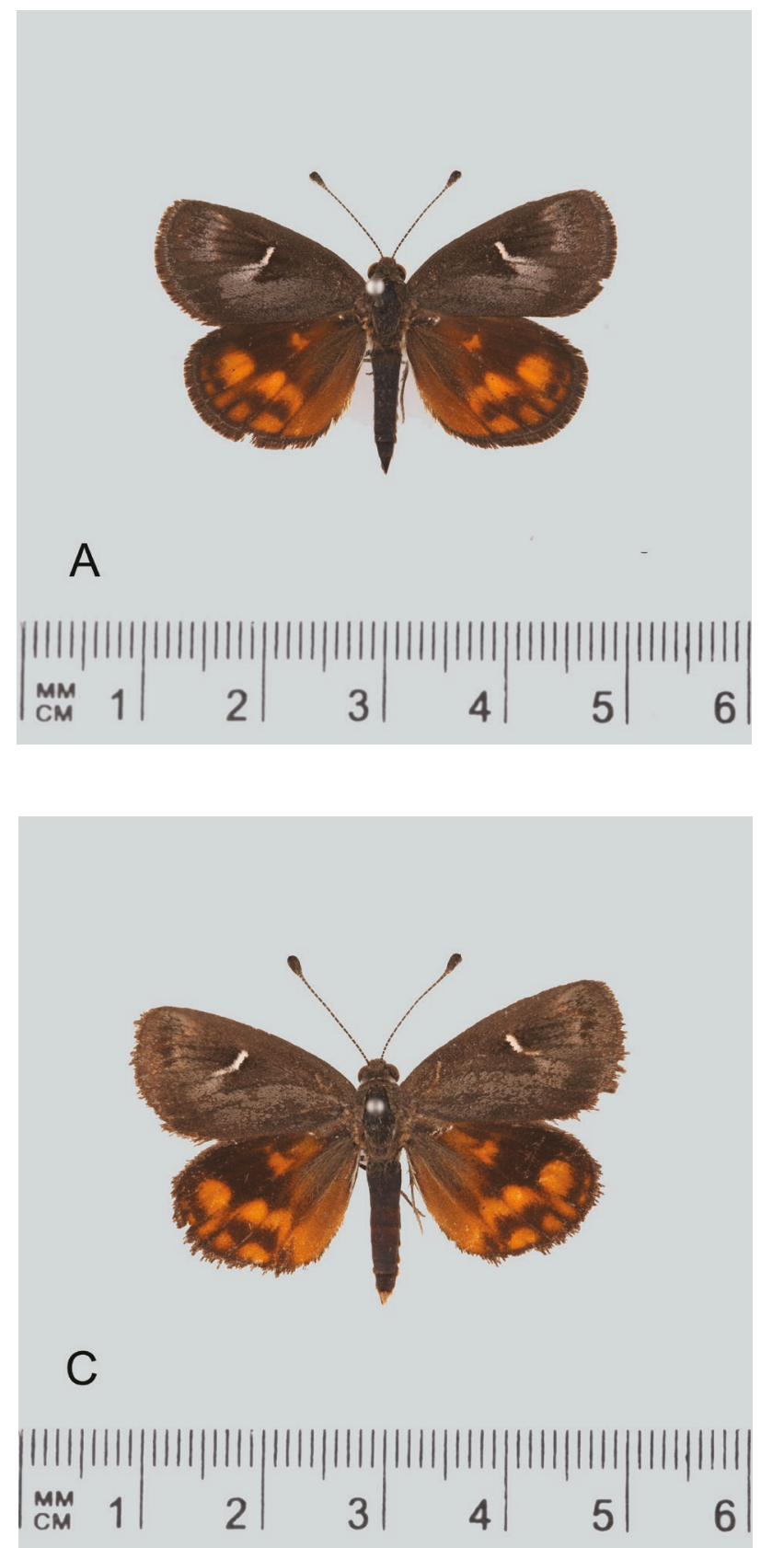

$\mathrm{km} \mathrm{S}$ of Billabong Roadhouse, $27^{\circ} 29^{\prime} 46^{\prime \prime} \mathrm{S}, 114^{\circ}$ 43' 14" E, 11 Nov 2009, A.A.E. Williams; Kalbarri National Park, $27^{\circ} 52^{\prime} 00^{\prime \prime} \mathrm{S}, 114^{\circ} 30^{\prime}$ 07" E, 11 Nov 2009, A.A.E. Williams; Pallarup Nature Reserve, $33^{\circ} 14^{\prime}$ 29" S, $119^{\circ} 45^{\prime}$ 45" E, 01 Jan 2010, A.A.E. Williams; Nature Reserve at Gunyidi, $30^{\circ} 08^{\prime} 48^{\prime \prime}$ S, $116^{\circ} 04^{\prime}$ 39" E, 12 Nov 2010, A.A.E. Williams; Gunyidi Nature Reserve, $30^{\circ} 11^{\prime} 36^{\prime \prime} \mathrm{S}, 116^{\circ} 02^{\prime}$ 05" E, 12 Nov 2010, A.A.E. Williams; $2 \mathrm{~km} \mathrm{~N}$ of Badgingarra, 30 22' 35" S, 115'29' 28" E, 09 Dec 2010, A.A.E. Williams; $9 \mathrm{~km} \mathrm{~N}$ of Cataby, 30 41' 50" S, $115^{\circ} 29^{\prime} 33^{\prime \prime}$ E, 09 Dec 2010, A.A.E. Williams;
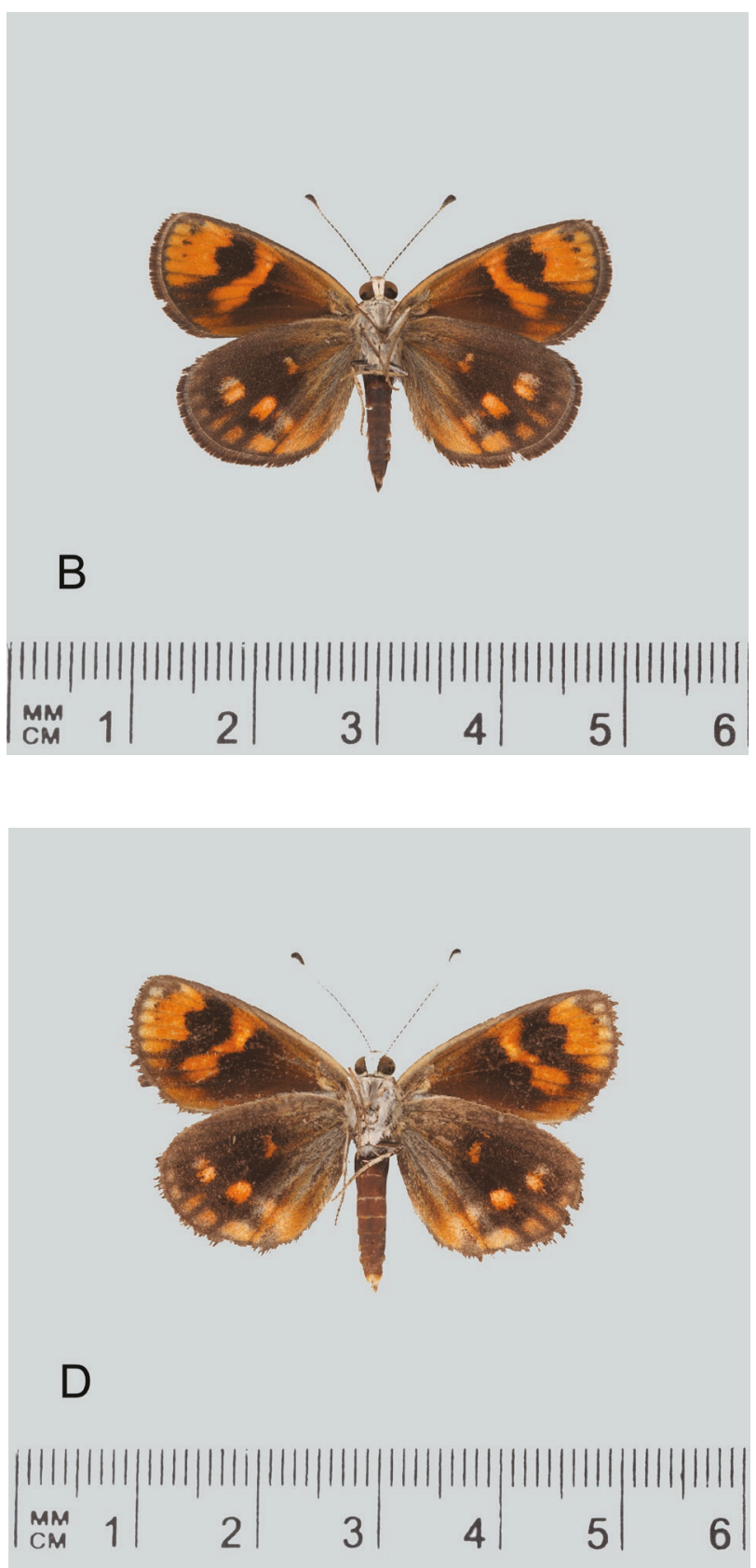

FIGURE 48 Synemon obscurella. A, ô Dorsal; B, ô Ventral (C2764) Western Australia, Wyalkatchem (WAM); C, o+ Dorsal; D, o Ventral (C1182) Western Australia, Nature Reserve at Gunyidi (WAM). (Photos: Brian Hanich, Western Australian Museum.) 
$2 \mathrm{~km} \mathrm{~S}$ of Cataby, 30 46' 24" S, 115 34' 05" E, 09 Dec 2010, A.A.E. Williams; Yandin Nature Reserve, $30^{\circ} 46^{\prime} 26^{\prime \prime} \mathrm{S}, 115^{\circ} 36^{\prime} 15^{\prime \prime}$ E, 09 Dec 2010, A.A.E. Williams; Minyulo Nature Reserve, $30^{\circ} 38^{\prime} 32^{\prime \prime} \mathrm{S}$, $115^{\circ} 34^{\prime} 30^{\prime \prime}$ E, 11 Dec 2010, A.A.E. Williams, F. Hort and J. Hort; Pallarup Nature Reserve, $33^{\circ} 14^{\prime}$ 59" S, $119^{\circ}$ 45' 29" E, 07 Jan 2011, A.A.E. Williams; Merredin Rock Bushland, $31^{\circ} 28^{\prime} 2^{\prime \prime}$ S, $118^{\circ} 17^{\prime}$ 48" E, 11 Nov 2011, A.A.E. Williams; Merredin,

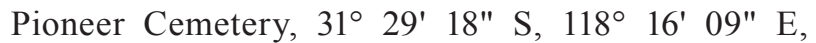
24 Nov 2011, A.A.E. Williams; Merredin, Tamma Parkland, $31^{\circ} 29^{\prime} 27^{\prime \prime}$ S, $118^{\circ} 16^{\prime} 24^{\prime \prime}$ E, 25 Nov 2011, A.A.E. Williams; Wyalkatchem Nature Reserve, $31^{\circ} 10^{\prime} 14^{\prime \prime} \mathrm{S}, 117^{\circ} 24^{\prime}$ 49" E, 25 Nov 2011, A.A.E. Williams; Wyalkatchem Water Catchment, 31 ${ }^{\circ} 09^{\prime}$ 47" S, $117^{\circ} 21^{\prime}$ 49" E, 03 Nov 2012, A.A.E. Williams; Yorkrakine Rock Nature Reserve, $31^{\circ} 25^{\prime} 27^{\prime \prime}$ S, $117^{\circ}$ $30^{\prime} 20^{\prime \prime}$ E, 10 Nov 2012, A.A.E. Williams; Hartley Reserve, $12 \mathrm{~km} \mathrm{~S}$ of Corrigin, $32^{\circ} 26^{\prime} 31^{\prime \prime} \mathrm{S}, 117^{\circ}$ 54' 04" E, 13 Nov 2012, A.A.E. Williams; $2.8 \mathrm{~km}$ $\mathrm{S}$ of Eneabba, $31^{\circ} 25^{\prime} 27^{\prime \prime} \mathrm{S}, 117^{\circ} 30^{\prime} 20^{\prime \prime} \mathrm{E}, 15 \mathrm{Dec}$ 2012, P. Hutchinson (PHC); Wicherina Reserve, E of Geraldton, 28 $8^{\circ} 44^{\prime} 00^{\prime \prime} \mathrm{S}, 115^{\circ} 00^{\prime} 56^{\prime \prime} \mathrm{E}, 19 \mathrm{Nov}$ 2013, A.A.E. Williams; Kalbarri National Park Euardy boundary, $27^{\circ} 29^{\prime} 42^{\prime \prime} \mathrm{S}, 114^{\circ} 31^{\prime} 38^{\prime \prime}$ E, 04 Nov 2014, A.A.E. Williams; Purnita Rock, 32 ${ }^{\circ} 50^{\prime}$ 30" S, $119^{\circ} 32^{\prime}$ 54" E, 30 Dec 2014, A.A.E. Williams;

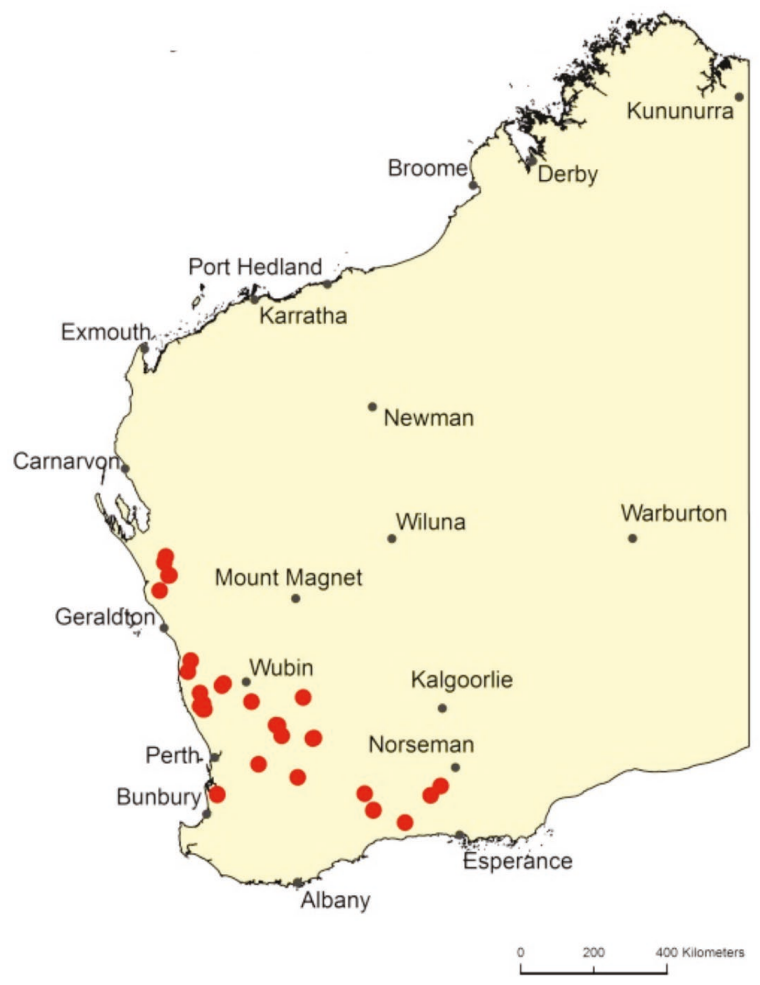

FIGURE 49 Map of Western Australia showing distribution of Synemon obscurella
West Point Road, Oldfield River, $33^{\circ} 32^{\prime} 47^{\prime \prime} \mathrm{S}, 120^{\circ}$ 32' 19" E, 30 Dec 2014, A.A.E. Williams; NorthamPithara Road, Ballidu, $30^{\circ} 35^{\prime} 11^{\prime \prime}$ S, $116^{\circ} 45^{\prime} 29^{\prime \prime}$ E, 24 Nov 2015, F. Hort and J. Hort; Lake Logue Nature Reserve, $29^{\circ} 51^{\prime} 15^{\prime \prime} \mathrm{S}, 115^{\circ} 11^{\prime} 55^{\prime \prime}$ E, 27 Nov 2015, A.A.E. Williams.

\section{Synemon phaeoptila Turner 1906 (Northern White-spotted Sun-moth)}

Figure 50

\section{BRIEF DESCRIPTION}

Synemon phaeoptila is a small sun-moth with rounded wings. The wingspans of specimens from Western Australia vary from 24 to $30 \mathrm{~mm}$ in males and 24 to $26 \mathrm{~mm}$ in females. In males the upper side of the forewing is pale brown, with a distinct white central spot; variable, gently curved white lines with contrasting dark brown edges radiate out from the basal area. The upper side of the hind wing is pale brown, merging to dark brown towards the outer edge. The underside of the forewing in the male is predominantly dark brown, with a somewhat obscure orange-brown terminal to subterminal band. The termen has a wide dark scale fringe. The underside of the male's hind wing is dull black, with distinct silvery-grey spots and markings, which extend into the dorsum alongside the abdomen. In females the upperside of the forewing is pale greybrown, with numerous pale lines radiating out from the base. The basal area on the upperside of the hind wing is grey, the remainder dull orange-brown, with several blurred dark brown subterminal spots. In females the underside basal area on both fore and hind wings is grey. The outer portion of the forewing is orange-brown, with a central white spot and four distinct elongate black subapical spots; the outer border is narrowly edged in black. The underside of the female's hind wing is dark, distinctively patterned with bands of small silvery-grey and white spots.

\section{DISTRIBUTION}

In Western Australia S. phaeoptila has been found only on the north Kimberly coastline, immediately east of Borda Island (Figure 51). The species also occurs in the Northern Territory and in Queensland.

\section{LARVAL FOOD PLANTS}

The larval food plant for $S$. phaeoptila has not been recorded in Western Australia, though on the mainland near Borda Island it is in all probability Chrysopogon fallax. On the Pinkerton Range in the Northern Territory, $55 \mathrm{~km}$ east of the Western Australian border, Chrysopogon latifolius is a recorded larval food 
plant (M.F. Braby, personal communication, 2016) (Braby 2011).

\section{HABITAT}

At the northern Kimberley site east of Borda Island, the sun-moths occur on a sandstone rise adjacent to a saline coastal inlet. The habitat is very open low Acacia and Grevillea woodland over a grassy understory dominated by a species of Chrysopogon. This grass is likely to be Chrysopogon fallax which occurs in similar habitat on nearby Borda Island (Greg Keighery, personal communication, 2016).

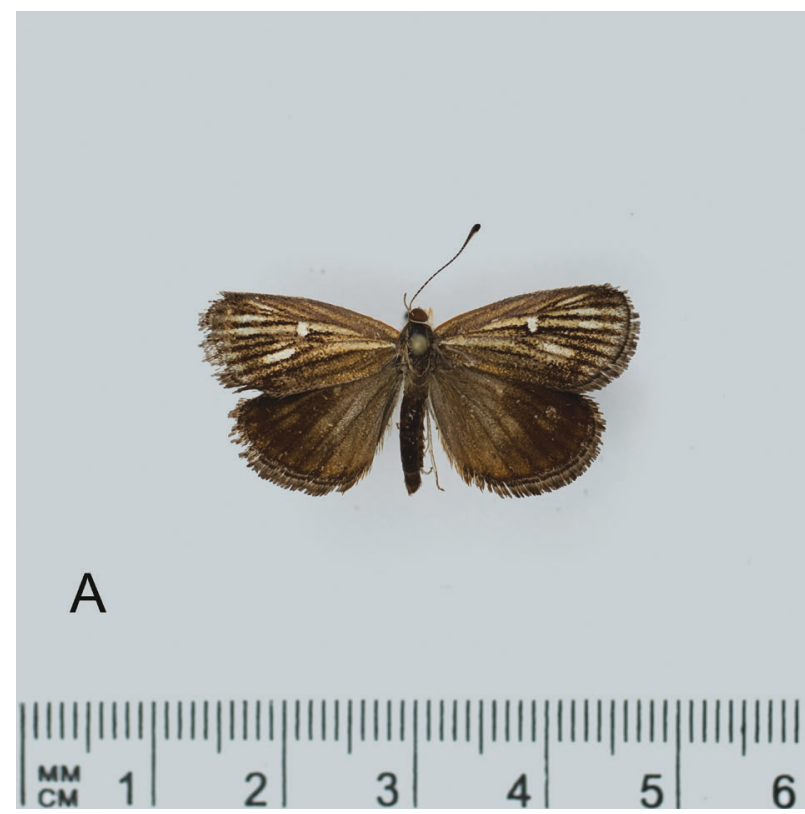

\section{BEHAVIOUR AND FLIGHT PERIOD}

On the mainland east of Borda Island, S. phaeoptila has been observed and filmed flying amongst dense green Chrysopogon sp. grasses. The sun-moths fly in early February and are active from mid morning to early afternoon.

\section{CONSERVATION STATUS}

Data deficient. In Western Australia, S. phaeoptila is only known from one coastal site in the northern Kimberley. Its lush Chrysopogon sp. grassland habitat
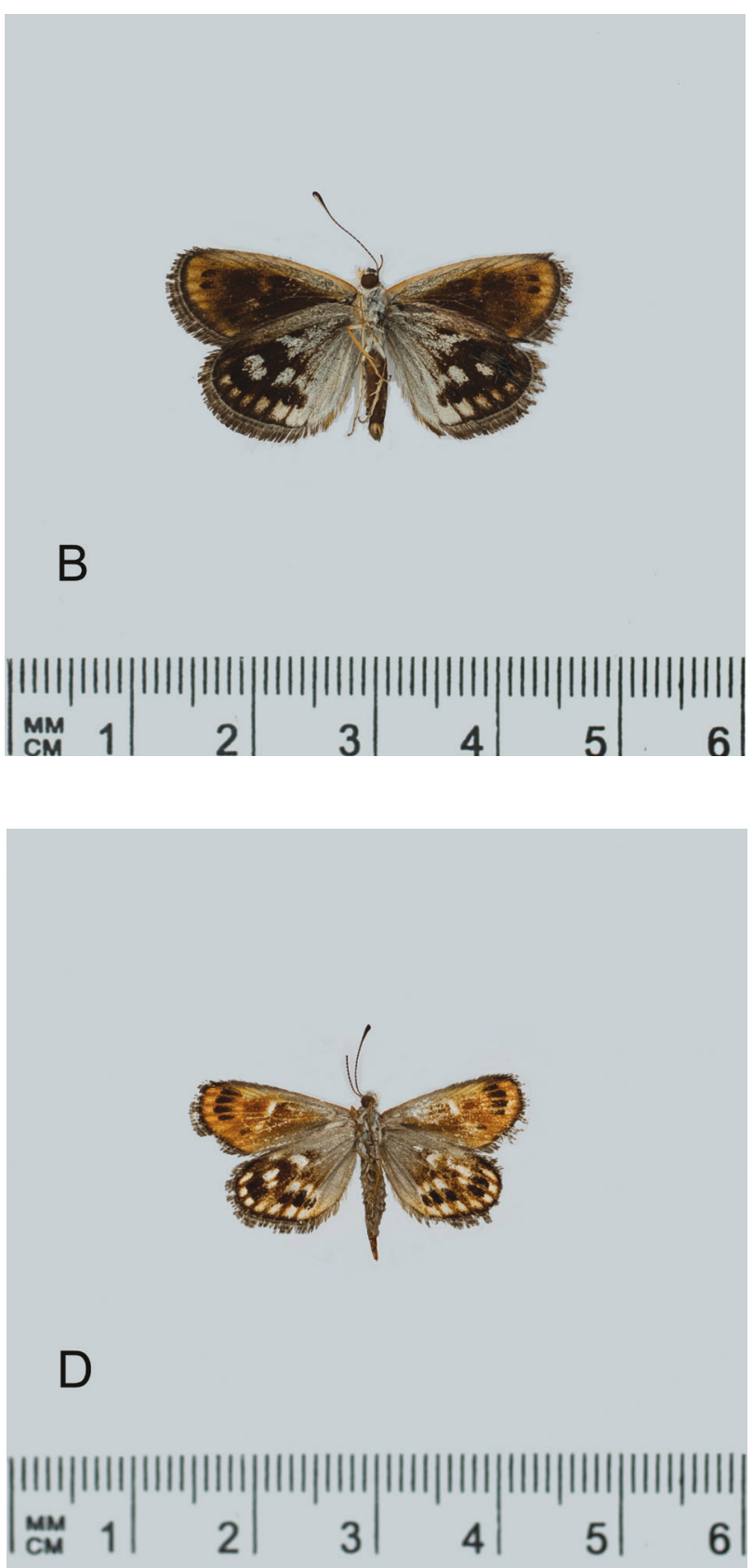

FIGURE 50 Synemon phaeoptila. A, ô Dorsal; B, ô Ventral (C3472) Western Australia, north Kimberley (WAM); C, 9 Dorsal; D, q Ventral (C3483) Western Australia, north Kimberley (WAM). (Photos: Nikolai Tatarnic, Western Australian Museum.) 
is apparently unusual in the region, where spinifexdominated ground cover is more the norm (J. Koeyers and M. Heath, personal communication, 2016). Insufficient surveys have been conducted along the north Kimberley coastline to accurately determine its distribution and conservation status in Western Australia. It is possible that this is an undescribed species, as males are consistently smaller and have three characters which distinguish them from most Northern Territory specimens; females are also marginally different (M.F. Braby, personal communication, 2016). Specimens from the Northern Territory's Pinkerton Range (near the Western Australian border), appear to be transitional in some of these characters. More specimens, and better quality material from the Kimberley is required before a thorough taxonomic assessment can be made (M.F. Braby, personal communication, 2016). We therefore provisionally include these Kimberley specimens with $S$. phaeoptila. There is no historical and one recent record.

\section{HISTORICAL RECORDS}

None.

\section{RECENT RECORDS}

Kimberley coast, E of Borda Island, $14^{\circ} 14^{\prime} 18^{\prime \prime} \mathrm{S}, 126^{\circ}$ 05' 08" E, 08 Feb 2016, J. E. Koeyers.

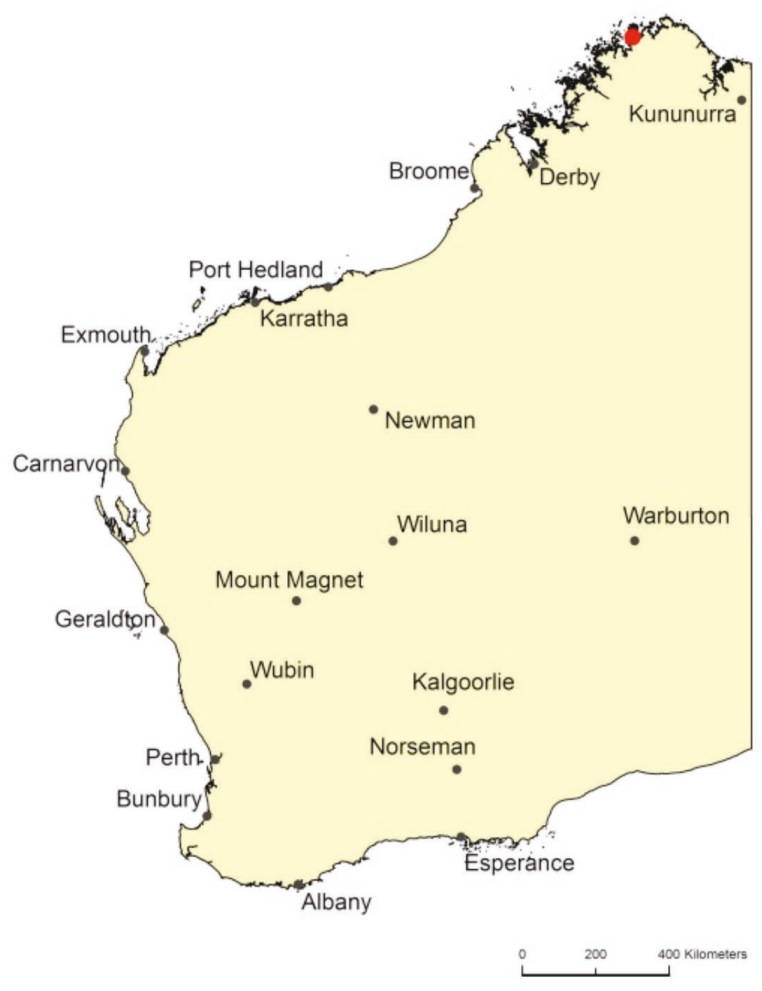

FIGURE $51 \quad$ Map of Western Australia showing distribution of Synemon phaeoptila.

\section{Synemon wulwulam Angel 1951 (Golden-flash Sun-moth)}

Figure 52

\section{BRIEF DESCRIPTION}

This is a medium sized sun-moth, its wingspan varying from 30 to $42 \mathrm{~mm}$. The sexes are similar, although females are typically larger. The shape of the forewing is distinctive, the termen being very rounded, culminating in a pointed apex. The base colour on the upper side of the forewing is grey-brown, with a contrasting greyish-white pattern that resembles the lateral view of a stylised face-mask. The rounded hind wing is dull brownish-black, the outer portion with a series of variable, slightly iridescent orange-brown or ochre-yellow markings that radiate out to the margin. In some individuals these markings are absent. On the underside, the basal area of both wings is dull black. The outer portion of the forewing is golden-yellow to brownish-yellow, with a distinct, dark subcostal median spot. The pattern on the outer portion of the hind wing resembles that on the upper surface. In Western Australia there is some variation in upperside forewing pattern between populations. Kununurra specimens are atypical, the face-mask pattern being the norm in all the other known Western Australian populations. (See Figure 52A-B depicting a specimen from Mitchell Plateau, and Figure 52C-D, depicting a specimen from Kununurra.). Angel (1951), notes that the most striking characteristic of the species is the large golden-yellow patch on the underside of the forewings. When the insect is in flight, the flashing of this bright patch makes the moth conspicuous and hence its common name.

\section{DISTRIBUTION}

Synemon wulwulam has a wide but disjunct distribution across northern Australia, from Queensland, through the Northern Territory, and into the Kimberley region of Western Australia where it is known from five locations: Derby (historical record), Mitchell Plateau round Kandiwal, Kelly's Knob in Kununurra, Lake Argyle, and the Victoria Highway close to the Northern Territory border (Figure 53).

\section{LARVAL FOOD PLANTS}

The larval food plant at Kelly's Knob, Kununurra, is the green form of Chrysopogon setifolius Stapf. Along the Victoria Highway close to the Northern Territory border, $S$. wulwulam breeds on a locally abundant bluegrey form of this species. In the Northern Territory, Plume Canegrass Sorghum plumosum (R. Br.) P. Beauv. is a recorded larval food plant (Braby, 2015). 


\section{HABITAT}

At Mitchell Plateau, S. wulwulam occurs on the rolling plateau uplands round Kandiwal. It is almost invariably found in very open woodland dominated by Ironwood (Erythrophleum chlorostachys) over patches of lowgrowing grasses including Chrysopogon fallax, Lemon Grass Cymbypogon bombycinus, and Heteropogon contortus. In Kununurra, the habitat on the lower slopes of Kelly's Knob is open savannah woodland over $C$. setifolius tussock grassland. Near the Northern Territory border, the habitat is very open savannah woodland
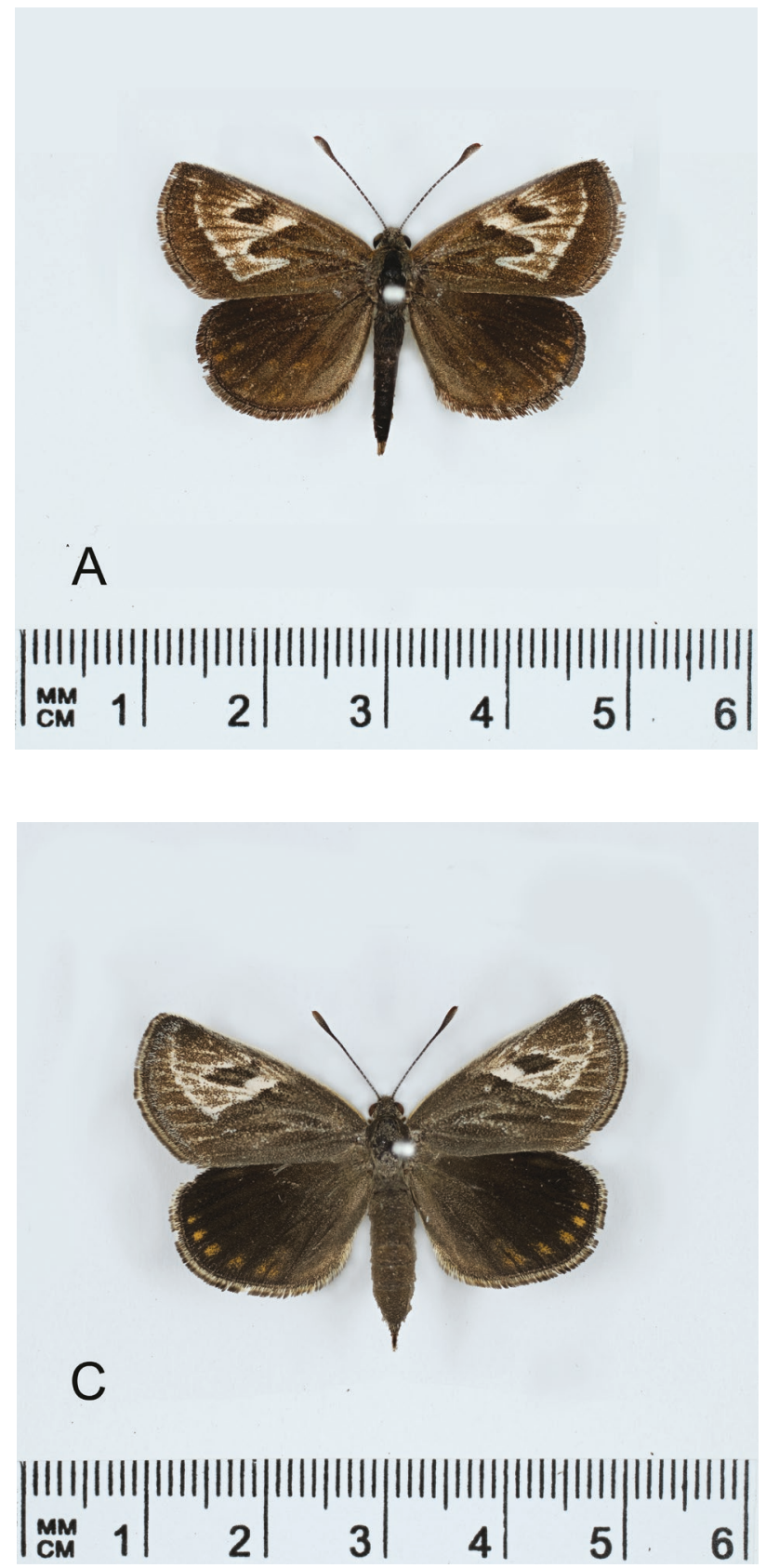

over a blue-grey form of $C$. setifolius, which grows extensively on well drained rocky hillsides.

\section{BEHAVIOUR AND FLIGHT PERIOD}

This sun-moth flies in warm to hot sunny conditions between 10:00 and 12:00 WST. The males are active amongst low-growing grasses, undoubtedly in search of unmated females. After midday, activity ceases abruptly. As these sun-moths have very reduced mouthparts, they must derive all their energy from stored larval fat reserves. The short daytime activity period may be an
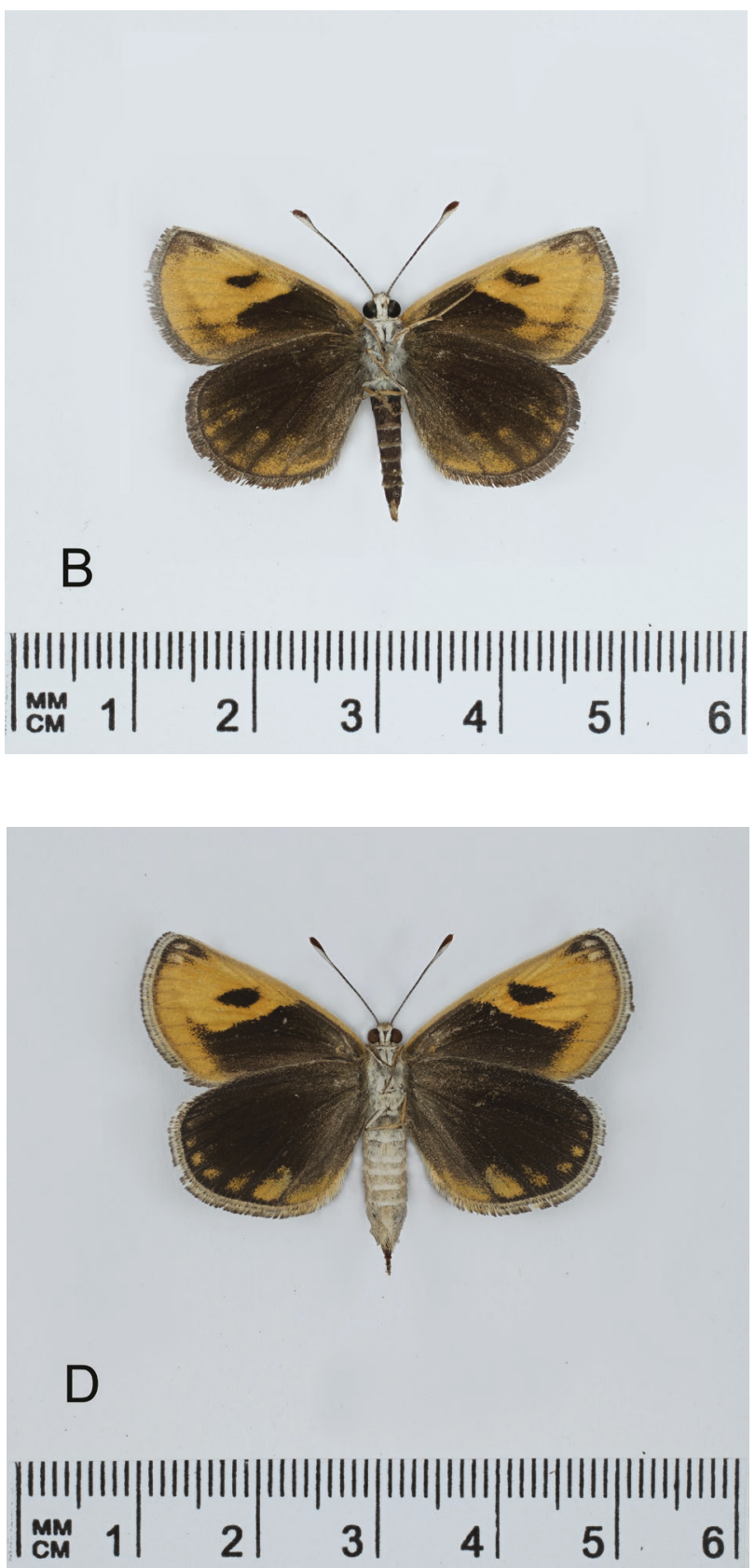

FIGURE 52 Synemon wulwulam. A, ô Dorsal; B, ô Ventral (C3188) Western Australia, Mitchell Plateau (WAM); C, o Dorsal; D, o Ventral (C3509) Western Australia, Kununurra (WAM). (Photos: Nikolai Tatarnic, Western Australian Museum.) 

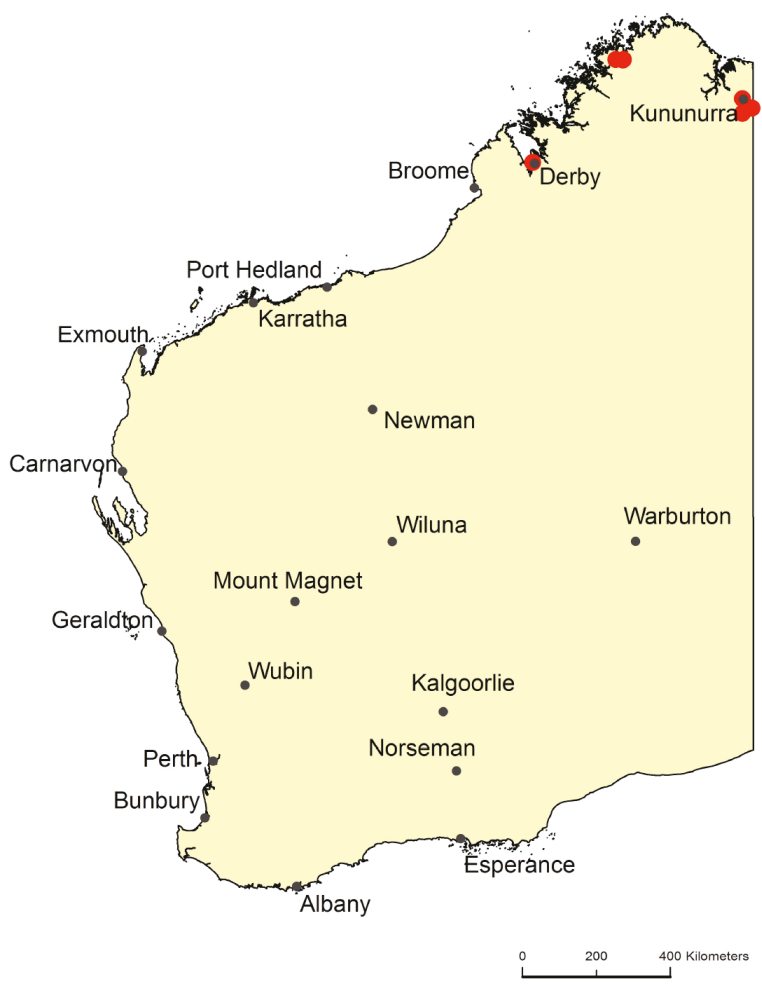

FIGURE 53 Map of Western Australia showing distribution of Synemon wulwulam.

energy saving strategy, with the males only active at times when freshly emerged females are likely to be encountered. A similar flight-time was reported for S. wulwulam at Lake Argyle (Geoff Walker, personal communication, 2015). On the Victoria Highway close to the Northern Territory border, a freshly emerged female with slightly crumpled soft wings was observed at 9:30 WST clambering up from the base of a $C$. setifolius grass tussock (A.A.E. Williams pers. obs). Two males were flying round this tussock. Near Borrolooa in the Northern Territory, males were most active between 11:30 and 12:00 CST. Females were observed ovipositing between 13:20 and 14:10 CST (Braby, 2015). In Western Australia $S$. wulwulam flies in May.

\section{CONSERVATION STATUS}

Data deficient. Insufficient surveys have been conducted to accurately determine the conservation status of this taxon in Western Australia. Survey effort to date suggests the species is probably uncommon and localised. Damage to the sun-moth's larval food plants by grazing cattle is a likely threat. There are two historical and 10 recent records.

\section{HISTORICAL RECORDS}

Mitchell Plateau, Mining Camp, $14^{\circ} 49^{\prime} 00^{\prime \prime} \mathrm{S}, 125^{\circ}$ 50' 00" E, 09 May 1983, J.C. Cardale; Derby (general), $17^{\circ} 19^{\prime} 00^{\prime \prime} \mathrm{S}, 123^{\circ} 38^{\prime} 00^{\prime \prime} \mathrm{E}$, date not recorded, collector unknown (MM).

\section{RECENT RECORDS}

Mitchell Plateau, near Kandiwal, $14^{\circ} 48^{\prime} 47^{\prime \prime} \mathrm{S}$, $125^{\circ} 50^{\prime} 20^{\prime \prime}$ E, 09 May 2014, A.A.E. Williams; Mitchell Plateau, near Kandiwal, $14^{\circ} 48^{\prime} 35^{\prime \prime} \mathrm{S}$, $125^{\circ} 50^{\prime} 14^{\prime \prime}$ E, 12 May 2014, A.A.E. Williams; Mitchell Plateau, near Kandiwal, $14^{\circ} 48^{\prime} 23^{\prime \prime}$ S, $125^{\circ}$ 39' 14" E, 12 May 2014, A.A.E. Williams; Mitchell Plateau, near Kandiwal, $14^{\circ} 48^{\prime} 50^{\prime \prime} \mathrm{S}, 125^{\circ} 49^{\prime}$ 54" E, 13 May 2014, A.A.E. Williams; Mitchell Plateau, near Kandiwal, $14^{\circ} 48^{\prime} 21^{\prime \prime}$ S, $125^{\circ} 50^{\prime} 43^{\prime \prime}$ E, 13 May 2014, A.A.E. Williams; Lake Argyle, S of Kununurra, $16^{\circ} 06^{\prime} 33^{\prime \prime} \mathrm{S}, 128^{\circ} 44^{\prime} 00^{\prime \prime} \mathrm{E}, 17$ May 2015, G. Walker and L. Walker; Lake Argyle, S of Kununurra, $16^{\circ} 06^{\prime} 32^{\prime \prime}$ S, $128^{\circ} 44^{\prime} 42^{\prime \prime}$ E, 14 May 2016, A.A.E. Williams; Kelly's Knob, Kununurra, $15^{\circ} 45^{\prime} 48^{\prime \prime} \mathrm{S}, 128^{\circ} 44^{\prime} 19^{\prime \prime}$ E, 16 May 2016, A.A.E. Williams; Victoria Hwy, $34 \mathrm{~km}$ SE Kununurra, $15^{\circ} 59^{\prime} 31^{\prime \prime} \mathrm{S}, 128^{\circ} 58^{\prime} 26^{\prime \prime}$ E, 18 May 2016, A.A.E. Williams; Victoria Hwy, $34 \mathrm{~km}$ SE Kununurra, $15^{\circ} 59^{\prime} 09^{\prime \prime} \mathrm{S}, 128^{\circ} 57^{\prime} 53^{\prime \prime}$ E, 19 May 2016, A.A.E. Williams.

\section{Synemon sp. 'Alan Graham' (Queen Victoria's Sun-moth)}

Figure 54

\section{BRIEF DESCRIPTION}

Synemon sp. 'Alan Graham' is only known from a single worn male specimen in the Australian National Insect Collection. It is a small, nondescript sun-moth with a wing-span of $35 \mathrm{~mm}$. The ground colour on the upper side of the forewing is greyish-brown; near the leading edge of the forewing there is a white subcostal spot. An indistinct white line radiates out from the wing base into the median area of the forewing, terminating below a group of less distinct whitish subapical markings. Eight elongate whitish termen spots are located close to the outer margin of the forewing. The basal two thirds of the upper side of the hind wing, including the dorsum, is dark brown, and encloses a small but distinct yellowish discal spot. The outer portion of the hind wing is pale brownish-yellow, with a series of brown subterminal spots and markings. The basal area on the underside of the forewing is dull brown. The remainder of the underside of the forewing is dull brownish-yellow, with a series of elongate white apical spots which are edged brown subapically. The basal area on the underside of the hind wing is brown. The outer portion of the hind wing is brownish-yellow and encloses four subterminal brown spots. Genitalia (slide 16590) and leg (slide 18534) are in ANIC, Canberra. 


\section{DISTRIBUTION}

Synemon sp. 'Alan Graham' is only known from Queen Victoria Rock near Coolgardie, in the semi-arid zone of Western Australia (Figure 55).

\section{LARVAL FOOD PLANT}

The larval food plant is unknown, but is probably a grass species which grows in the vicinity of Queen Victoria Rock. This sun-moth is morphologically most similar to the Synemon collecta / Synemon colona species group, whose larvae feed on grasses (Grund 2011).

\section{HABITAT}

Queen Victoria Rock is a large exposed granite outcrop fringed by sedges and grasses, which in turn are overshadowed by mixed shrublands and eucalyptus woodland.

\section{BEHAVIOUR AND FLIGHT PERIOD}

Nothing is known of the behaviour of this sun-moth, except that it flies in March.

\section{CONSERVATION STATUS}

Data deficient - possibly endangered. Synemon sp. 'Alan Graham' is undoubtedly rare and local. Searches for this taxon conducted in February and March, both at Queen Victoria Rock and other nearby rocks, have been unsuccessful. Further surveys are required to locate additional populations and identify the sun-moth's larval food plant. There is one historical and no recent record.

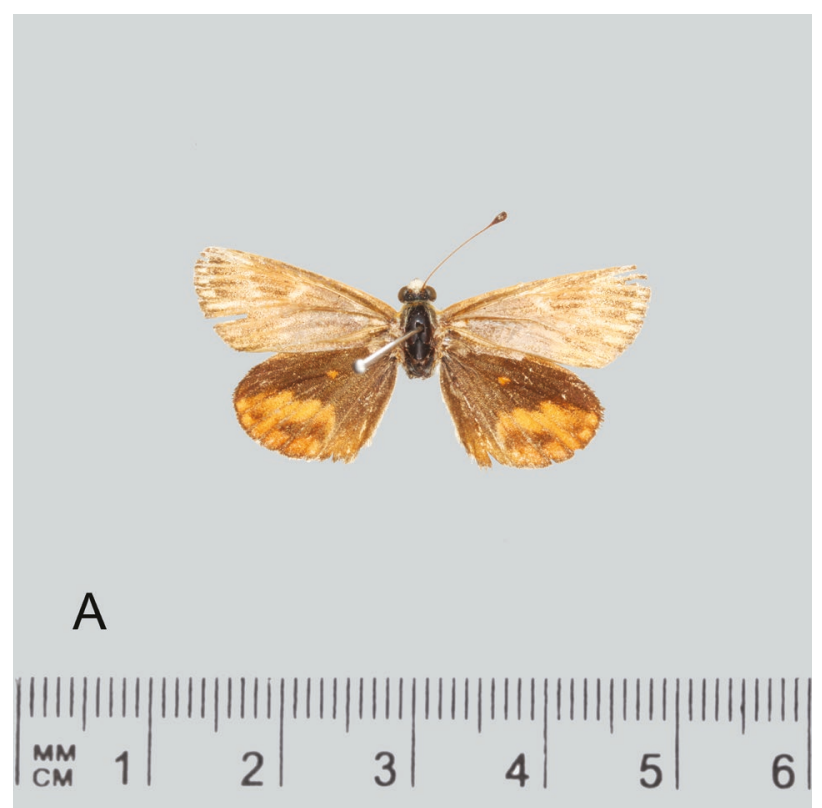

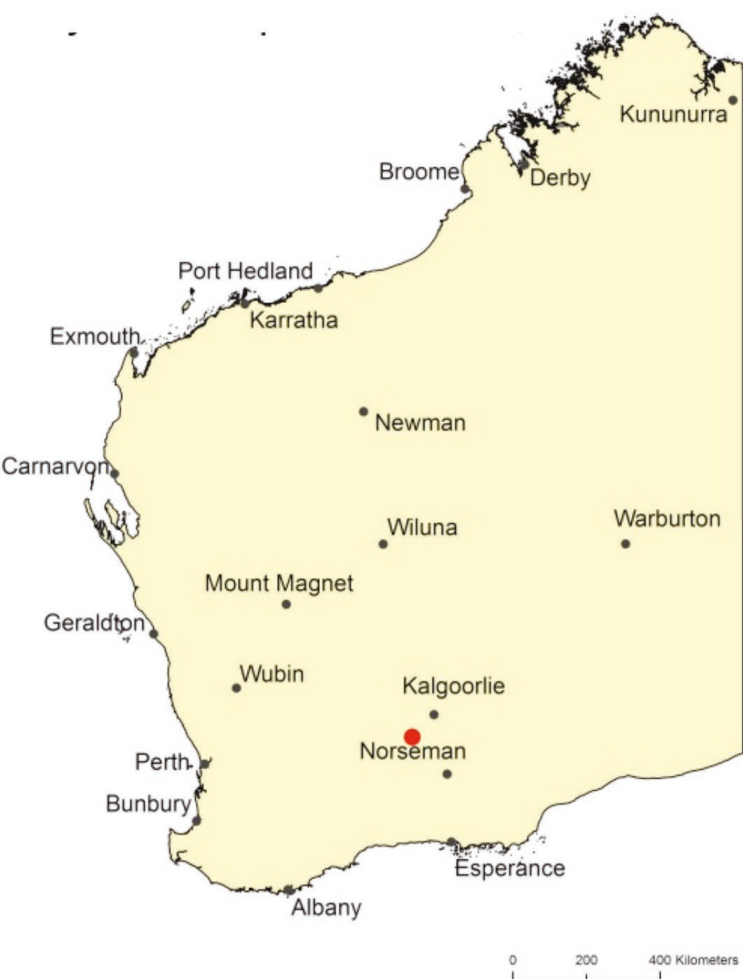

FIGURE 55 Map of Western Australia showing distribution of Synemon sp. 'Alan Graham'.

\section{HISTORICAL RECORDS}

Queen Victoria Rock, 31 $17^{\prime} 32^{\prime \prime}$ S, $120^{\circ} 55^{\prime} 32^{\prime \prime}$ E, 13 Mar 1988, A.J. Graham.

\section{RECENT RECORDS}

None.

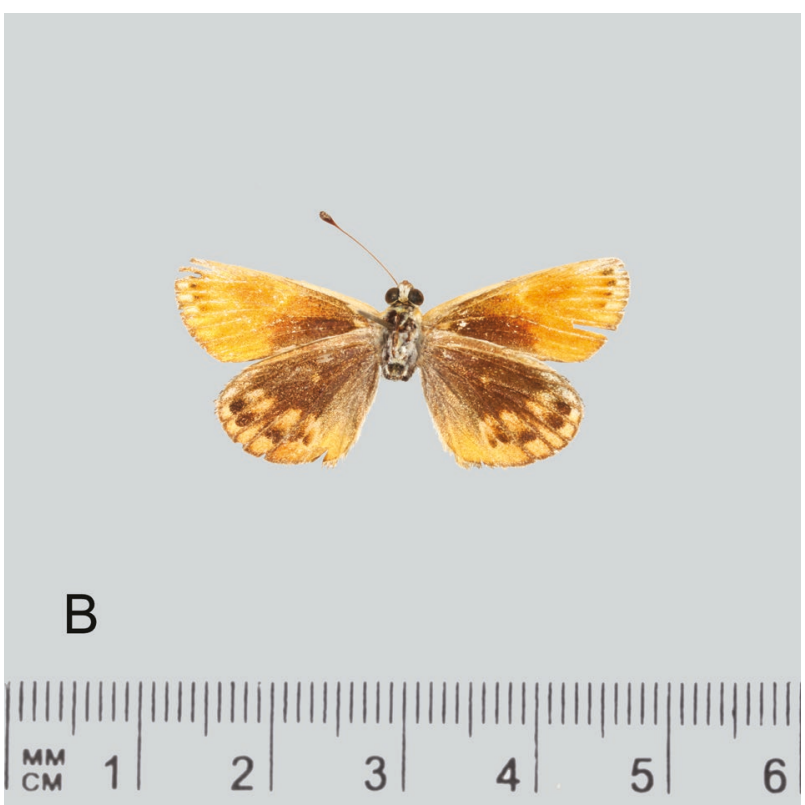




\section{Synemon sp. 'Eradu' (Ochre Sun-moth)}

Figure 56

\section{BRIEF DESCRIPTION}

Synemon sp. 'Eradu' is a small species with a wingspan of approximately $28 \mathrm{~mm}$. The upper side of the forewing is dull grey, with a small, indistinct central white spot. The upper side of the hind wing is dull ochre orange-brown, with shadowy darker under-markings. The underside is grey-brown, with subdued orangebrown markings on both the fore and hind wings.

\section{DISTRIBUTION}

This sun-moth is a Western Australian endemic. It is known from the boundary between Kalbarri National Park and Eurardy Station, $95 \mathrm{~km}$ north of Northampton; from Eradu, $40 \mathrm{~km}$ east of Geraldton; and further south from Watheroo National Park, $180 \mathrm{~km}$ north of Perth (Figure 56). The original four specimens, held in the Queensland Museum, were collected at Eradu by J. Clark on 21 November 1926 (E.D. Edwards, personal communication, 2013). Since then two specimens have been found: one collected by T.F. Houston near Eurardy Station, the other by M.R. Williams at Watheroo National Park.

\section{LARVAL FOOD PLANT}

The larval food plant is unknown, but may be Triodia danthonioides (F. Muell.) Lazarides, which occurs at all three sites where the sun-moth has been found.

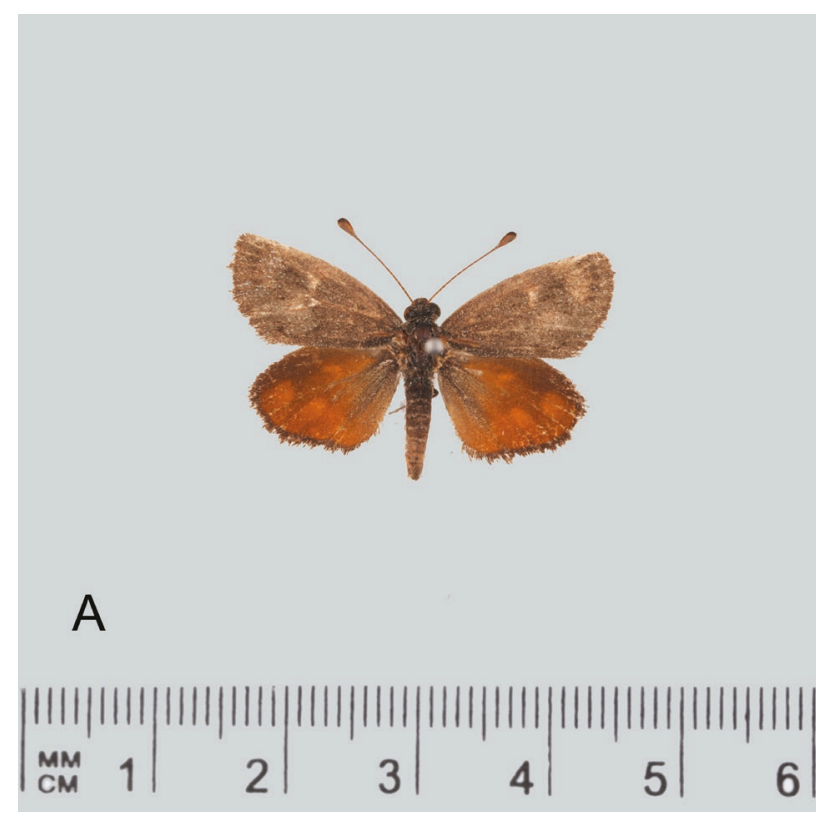

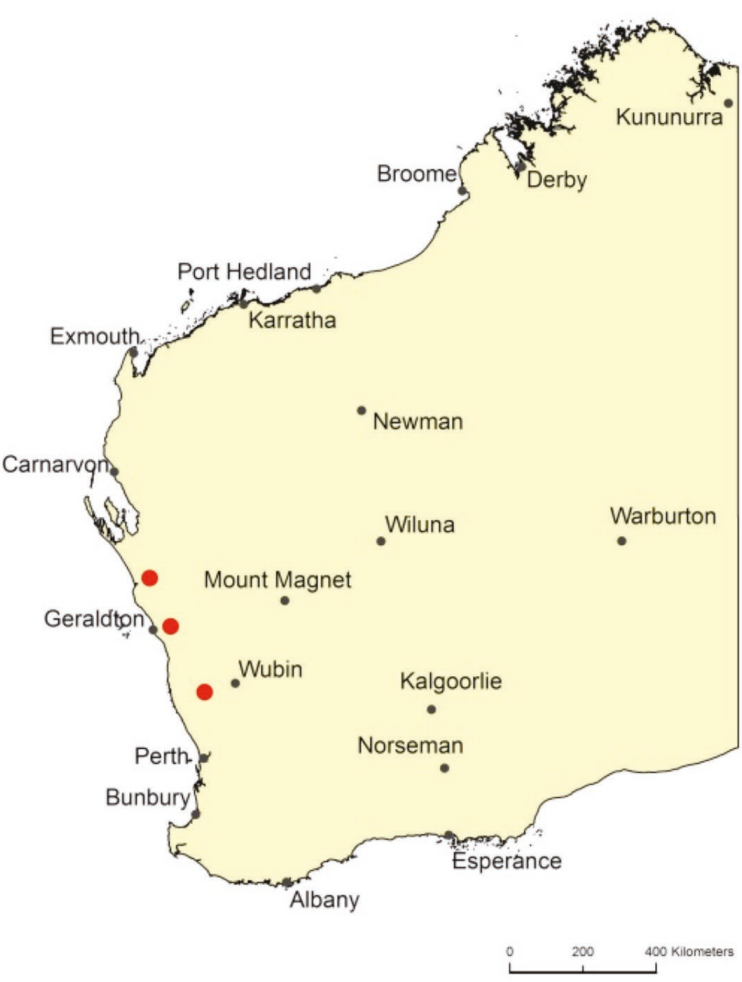

FIGURE 57 Map of Western Australia showing distribution of Synemon sp. 'Eradu'.

\section{HABITAT}

At the northern Eurardy site $S$. sp. 'Eradu' was collected in an extensive area of shrubland and sedges growing on sandy soil. At Watheroo National Park the species was collected at the edge of Banksia-dominated

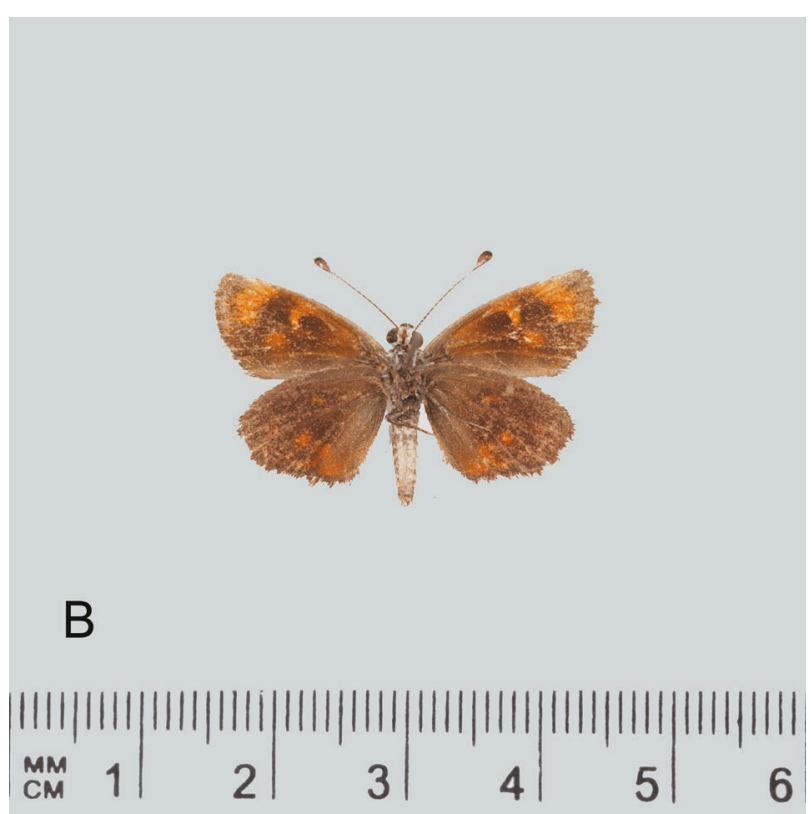


woodland with a sparse shrub understory. A potential larval food plant identified at Watheroo National Park is the tall robust tussock spinifex grass $T$. danthonioides. This species extends north to Shark Bay, where it was seen close to the northern Eurardy site. Interestingly, a closely allied species, Triodia bromoides (F. Muell.) Lazarides, also occurs in the Shark Bay area (Greg Keighery, personal communication, 2013).

\section{BEHAVIOUR AND FLIGHT PERIOD}

Little is known of this species' behaviour. The original specimens' label data lists only the locality, date and collector. The specimen collected at Watheroo National Park was caught on 13 November 2002, and was flying fast along a gravel road through Banksia-dominated woodland, at precisely the time that $S$. catocaloides was experiencing one of its periodic mass emergences.

\section{CONSERVATION STATUS}

Data deficient - possibly endangered. This taxon is very rare and only six specimens are known to exist. Further surveys are needed to determine its distribution, larval food plant and occurrence in the conservation estate. There are two historical and one recent records.

\section{HISTORICAL RECORDS}

Eradu, $40 \mathrm{~km}$ E of Geraldton, 28 41' 45" S, 115 $02^{\prime} 30^{\prime \prime}$ E, 21 Nov 1926, J. Clark (QM); Kalbarri National Park / Eurardy boundary, 27\% 30' 22" S, 114 31' 39" E, 09 Nov 1999, T. F. Houston (WAM).

\section{RECENT RECORDS}

Watheroo National Park, 30 19' 04" S, 115 52' 26" E, 13 Nov 2002, M.R. Williams.

\section{Synemon sp. 'Roper River' (White-veined Sun-moth)}

Figure 59

\section{BRIEF DESCRIPTION}

This is a medium sized distinctive sun-moth, with a wingspan of about 30 to $35 \mathrm{~mm}$. In the male the upper side of the forewing is grey-brown, with a long slightly curved white line radiating outwards from the base. A series of shorter parallel white markings are located on the outer portion of the wing, with four less prominent blackish apical spots near the wing tip. The basal half on the upper side of the hind wing is dull black. The outer portion is orange-brown and encloses three or four black marginal spots. On the underside the base of both the fore and hind wing is brownish-black. The outer areas are dull orange to orange-brown. Both fore and hind wings have a series of subapical dark spots. In the female, the upper side of the forewing is pale greyishbrown, with similar but less distinct white line markings to those found in the male. On the upper side of the hind wing the basal half is brown; the outer portion is warm orange-brown, with a band of large, almost fused, black subterminal spots. The outer margin of the hind wing is brownish-black. On the underside the female is generally pale yellow-brown with the basal area tinged brown. The forewing has five elongate blackish-brown apical to subapical spots. The hind wing has a similar band of dark subterminal spots.

\section{DISTRIBUTION}

Synemon sp. 'Roper River' occurs sporadically in the top end of the Northern Territory and the Kimberley. In Western Australia it has only been recorded from 10 miles $(16 \mathrm{~km}$ ) south-east of Halls Creek (Figure 58). A single specimen in the DAFC was collected there in May 1944. The specimens illustrated (Figure 59) are from the Northern Territory.

\section{LARVAL FOOD PLANT}

The larval food plant has not been recorded in Western Australia. In the Northern Territory the sunmoth breeds on Golden Beard Grass Chrysopogon fallax S.T. Blake (Braby 2011), and Ribbon Grass Chrysopogon pallidus (R. Br.) Steud. (E.D. Edwards, personal communication, 2015).

\section{HABITAT}

The habitat in Western Australia has not been specifically identified. It is likely to occur in grassland where Chrysopogon sp. ribbon grasses are present. In the Northern Territory, adults have been recorded at Limnen National Park in open savannah woodland over grassland (Braby 2011).

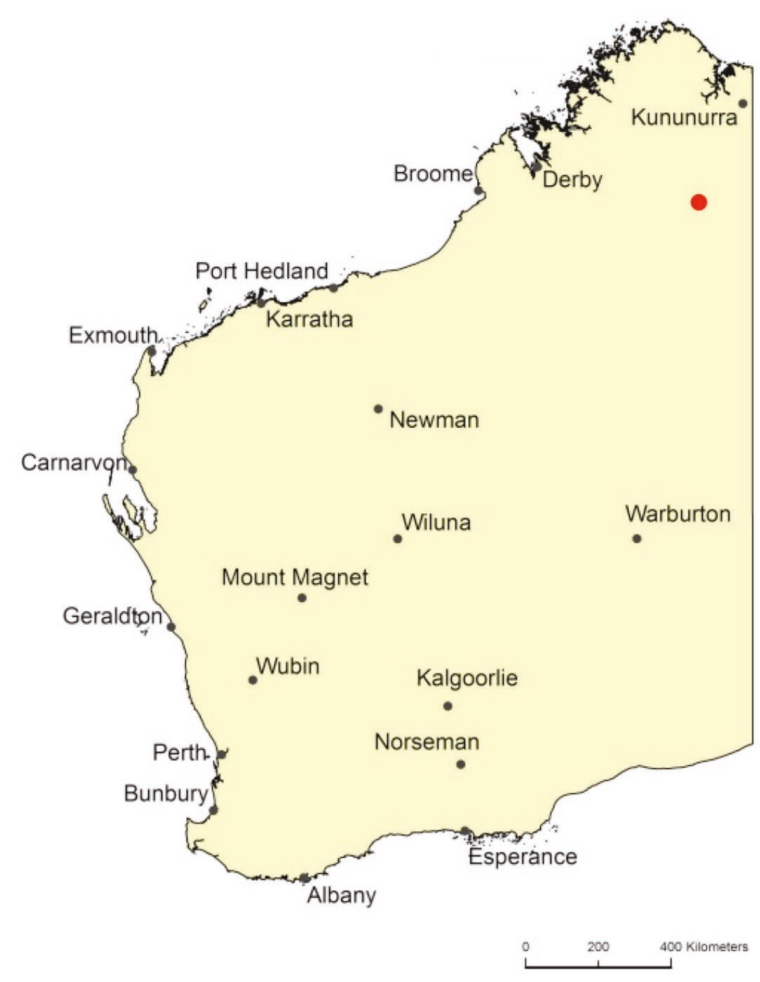

FIGURE $58 \quad$ Map of Western Australia showing distribution of Synemon sp. 'Roper River'. 


\section{BEHAVIOUR AND FLIGHT PERIOD}

Nothing is known of this species' behaviour in Western Australia. An adult was recorded near Halls Creek in May 1944. In the Northern Territory adults were recorded at Limmen National Park on 14 May 2009 (Braby 2011) and Barkly Tableland on 6 May 2015 (M.F. Braby, personal communication, 2015).

\section{CONSERVATION STATUS}

Data deficient. Synemon sp. 'Roper River' appears to have a very limited distribution in Western Australia,
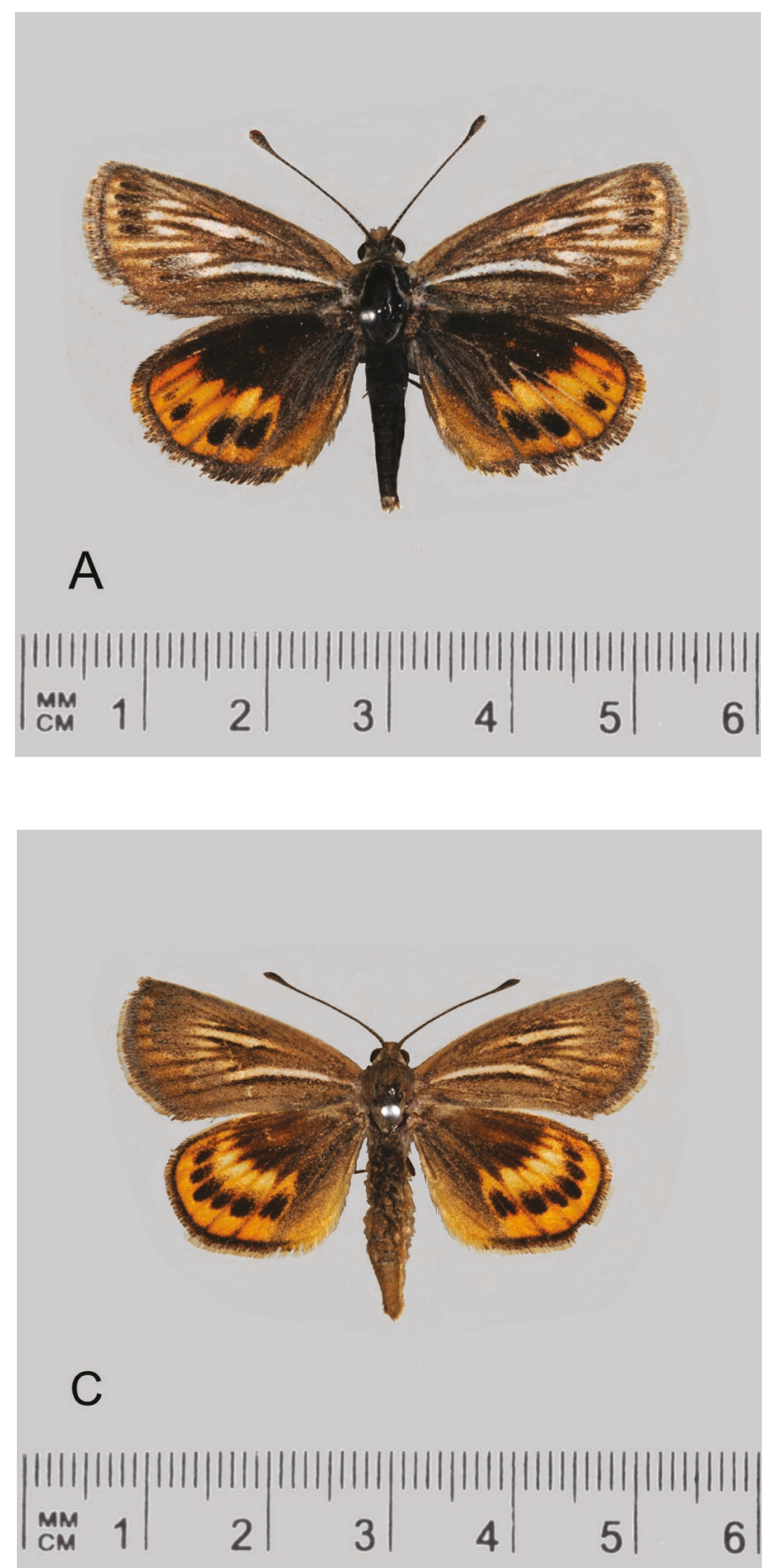

being known from only one historical record. Insufficient surveys have been conducted to accurately determine the species' distribution and conservation status in Western Australia. There is one historical and no recent record.

\section{HISTORICAL RECORDS}

$16 \mathrm{~km}$ SE of Halls Creek, $18^{\circ} 20^{\prime} 00^{\prime \prime} \mathrm{S}, 127^{\circ} 46^{\prime} 00^{\prime \prime}$ E, May 1944, collector unknown (DAFC).

\section{RECENT RECORDS}

None in Western Australia.
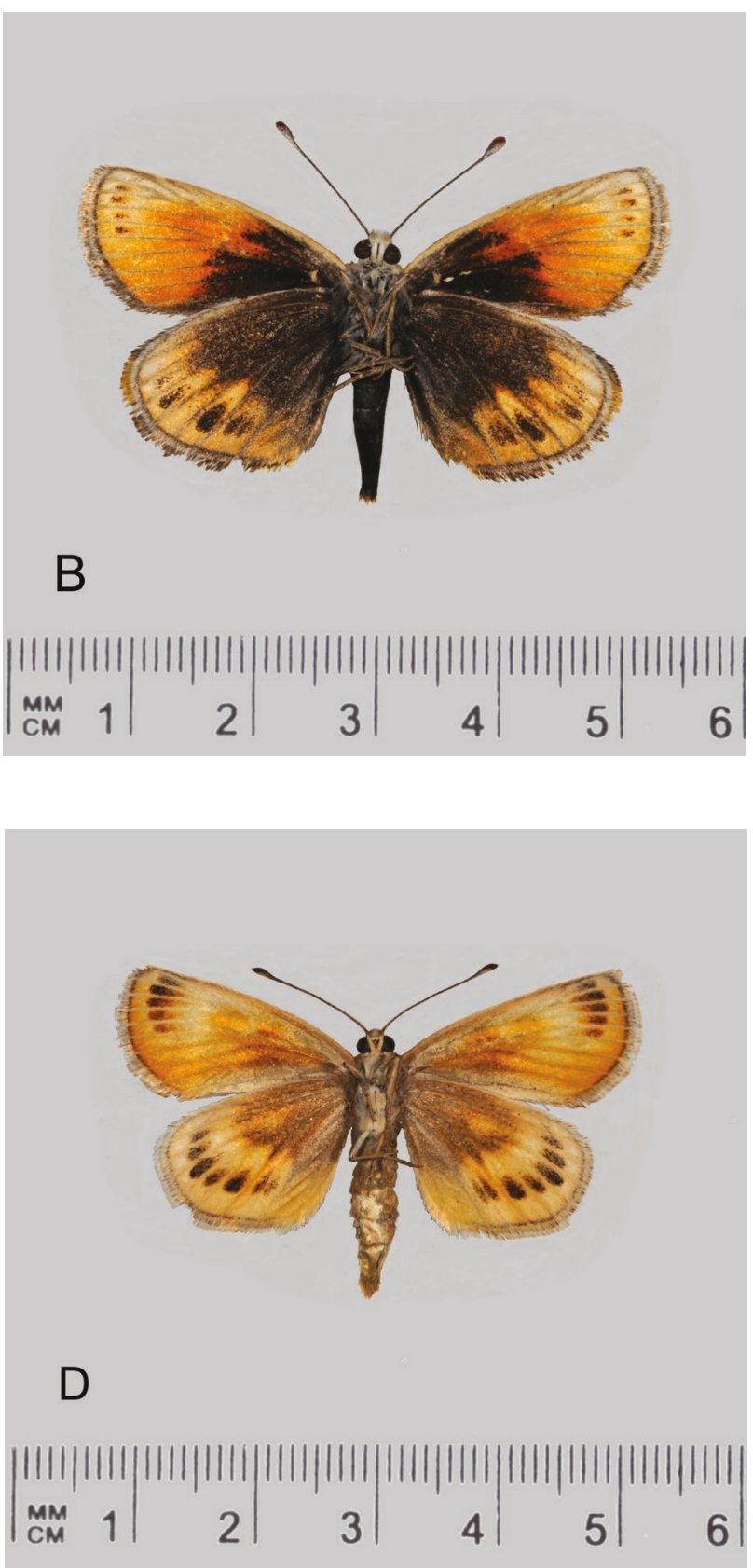

FIGURE 59 Synemon sp. 'Roper River'. A, §ิ Dorsal; B, ô Ventral, Northern Territory, 1 km north of Barkly Highway (MFBC); C, o Dorsal; D, o Ventral, Northern Territory, Nathan River Ranger Station, Limnen National Park (MFBC). (Photos: Michael Braby, CSIRO, Canberra.) 


\section{DISCUSSION}

\section{SPATIAL DISTRIBUTION AND DIVERSITY}

The diversity of the Western Australian sun-moth fauna is the highest of any State in Australia. In particular, the south-western region, roughly south of a line running from Geraldton to Caiguna, supports the richest sun-moth fauna, with 24 of the 29 species recognised in this paper. Twenty two of the 24 southwestern species $(92 \%)$ are endemic to the region. The heavily weighted distribution of sun-moth species in the south-western region is very evident in Figure 63

This sun-moth diversity is inextricably linked to the distribution and abundance of their food plants: those sun-moths which use larval food plants that are common and widespread also tend to be common and widespread. Examples include S. catocaloides, which uses the widespread Tussocky Cord-rush (Ecdeiocolea monostachya), and $S$. jcaria, which uses the very widespread Scented Mat-rush (Lomandra effusa). Conversely, $S$. sp. 'Victoria Rock' has a locally restricted distribution because its larvae feed on Lepidosperma drummondii, which in the Goldfields and Great Western Woodlands appears to grow only on isolated granite outcrops.

There are a number of reasons for the diverse nature of Western Australia's Castniidae fauna. The first is that south-western Western Australia encompasses the Southwest Australian Floristic Region, which is recognised as a global hotspot of plant biodiversity (Hopper and Gioia 2004). The habitat occupied by southwestern sun-moths is frequently species rich open low heath and woodland. Amongst the vast array of plant species found in this vegetation type are numerous sedges (Cyperaceae), mat-rushes (Asparagaceae), cord-rushes (Ecdeiocoleaceae), and grasses (Poaceae). Many species within these four plant families have rhizomatous root systems upon which sun-moth larvae are able to feed. Places where these plants are numerous frequently support two or more species of sun-moth. Combined with the availability of larval food plants is an abundance of spring flowering shrubs and annuals. These plants provide a rich nectar energy source for insects, including adult spring flying sun-moths. Almost all spring flying sun-moth species are equipped with a coiled retractable proboscis and likely live for extended periods, replenishing their energy by drinking nectar. The exception is $S$. edwardsi, which flies in late spring but has a reduced relict proboscis.

Another factor which enhances diversity among south-western sun-moths is that different species fly at different times of the year. Rather than flying in spring, some species emerge during summer or autumn. Both of those aspects of diversity have been documented at Wyalkatchem Nature Reserve, where six sun-moth species are known to occur (Williams and Williams 2013a). These sun-moths fly in spring, summer and autumn, with little overlap in their flight periods. Where they do overlap, each sun-moth species uses a different larval food plant. Three species, $S$. catocaloides, $S$. nupta and $S$. sp. 'Perth', may be seen together at Wyalkatchem in spring. The fourth species, Synemon obscurella, tends to fly in early and mid summer, whereas $S$. $s p$. 'Bob Hay' does not appear until February; the sixth species, S. jcaria, flies in February and March, but in quite different woodland habitat and using a different larval food plant, Scented Mat-rush $(L$. effusa) (Williams A. et al. 2012; Williams and Williams 2013a). These latter three sun-moths, which appear in the hot, dry summer and in autumn at Wyalkatchem, fly at times when there are few if any flowering plants, so that nectar is not readily available. The mouthparts of these species have become greatly reduced (Williams and Williams 2013a); instead of relying for energy on nectar, they rely on body fats accumulated during the larval stage. The individual adult lifespan of these nonfeeding summer flying species may be only a few days. However, not all summer flying sun-moths are unable to feed. For example, $S$. sp. 'Ravensthorpe' has a functional coiled proboscis, presumably because it occurs near the coast, where some plants still flower in December and early January.

Another interesting finding is that two sun-moths, common in the south-western region, $S$. catocaloides and $S$. obscurella, use the same larval food plant $(E$. monostachya). At Wyalkatchem, these two sun-moths fly at different times of the year: $S$. catocaloides in October and $S$. obscurella in November and December. Ecdeiocolea monostachya forms large, robust clumps, and is often dominant and widespread where it occurs. It is able to withstand the impact of two species of Castniidae larvae feeding simultaneously on its deep rhizomes. It is possible that larvae of a third species, $S$. sp. 'Bob Hay', may also feed on E. monostachya, but this has not been definitely confirmed.

In contrast to the richness of sun-moths in the southwest of the State is the paucity of species in the north (Williams A, 2011). The reason for this disparity may simply be a lack of suitable sedge food plants in northwestern Australia; instead grasses predominate, and these appear to be the only larval food plants. The five sun-moth species found in northern Western Australia generally occur in tropical or sub-tropical savannah woodlands, where grasses make up the bulk of the understory. The larval food plants for $S$. austera, $S$. phaeoptila, S. wulwulam and S. sp. 'Roper River' are native grasses, and the same is likely to be true of $S$. brontias (Braby 2011, 2015; Williams A. 2011).

It is interesting that, although there are so few northern species, they follow a similar flight-time separation pattern to those in the south. Of the three species known from the Kimberley, two, S. wulwulam and $S$. sp. 'Roper River', fly in May at the start of the northern dry season; one, $S$. phaeoptila, flies in February at the peak of the hot summer wet season. The two species known from the Pilbara and Gascoyne fly in spring (September to November), S. austera somewhat later than S. brontias. 


\section{REMARKS ON TAXONOMIC STATUS AND MORPHOLOGICAL CHARACTERS}

The sun-moth species occurring in the south-west of the State typically have distinctively coloured red, yellow or orange hind wings. This is not so for the five northern species, all of which have dull-coloured hind wings. The reason for this difference is unclear. One feature that is common to all Australian sun-moths (with the notable exceptions of $S$. directa and $S$. sp. 'Victoria Rock') is the cryptic pattern on the upper side of their forewing. In their settled posture, with wings folded back over the body, this pattern is a very effective camouflage.

Twenty-six of the 29 species recognised in this paper can usually be distinguished from each other by wing pattern alone:

1. Synemon sophia species group: $S$. catocaloides, $S$. leucospila, S. maja, S. nupta, S. sophia, S. sp. 'Bob Hay', S. sp. 'Mount Ragged', S. sp. 'Yarloop'.

2. Synemon directa species group: S. directa, S. sp. 'Victoria Rock'.

3. Synemon magnifica species group: S. notha, S. sp. 'Moirs Rock', S. sp. 'Mount Dale', S. sp. 'Ravensthorpe'.

4. Synemon laeta species group: S. edwardsi, S. gratiosa, S. jcaria.

5. Synemon 'grass-feeding' species group: S. austera, S. brontias, S. nais, $S$. obscurella, S. phaeoptila, $S$. wulwulam, $S$. sp. 'Alan Graham', $S$. sp. 'Eradu' and $S$. sp. 'Roper River'.

The remaining three species, $S$. sp. nr. discalis, $S$. sp. 'Leeman' and $S$. sp. 'Perth', which belong to the Synemon sophia Species Group, are more problematic because they have similar wing patterns and colouration (Figures 14, 16 and 20) and their species status is yet to be formally determined. Of particular interest is the group of sun-moths which in this paper are lumped together under E.D. Edwards' interim name tag $S$. sp. 'Perth'. These sun-moths cover a wide area within the south-western region (Figure 21), and their hind wing colour pattern varies from orange to orange-yellow. It is unclear whether this is an exceptionally variable and widespread species, or whether it comprises a number of closely related species. Genetic examination of specimens from across the range will be needed to clarify the situation. The similar looking species, $S$. maja (Figure 6) and S. sp. nr. discalis (Figure 14) are genetically distinct (Williams M. et al 2012). Synemon sp. nr. discalis from Western Australia and Synemon discalis from eastern Australia can be distinguished on wing pattern alone, (Fabian Douglas, personal communication 2015), but their genetic relationship has yet to be tested. The taxonomic relationships of several Western Australian sun-moths are currently unclear and the relationships of some Western Australian populations with those of eastern Australia is being studied using molecular phylogenetics by A. Kallies and M.R. Williams. Initial genetic comparisons of a few Western Australian species (Williams M. et al. 2012) has shown that S. sophia and S. sp. 'Yarloop' are a pair of closely related species, and that $S$. sp. 'Perth' and $S$. sp. 'Leeman' are another such pair. The only Western Australian sun-moth for which detailed phylogenetic information is available is $S$. gratiosa. Phylogenetic analysis has shown it to be a single (monophyletic) entity (Williams M. et al. 2012), with the morphologically similar species $S$. jcaria as a very close relative. These two species are related to $S$. edwardsi, which flies in spring (Williams M. et al. 2012; Williams and Williams 2016a).

\section{LIFE HISTORIES}

The life histories for most sun-moths are either incompletely known or have not been formally documented, but the life cycle patterns are essentially the same for all species. Only the life history of Synemon magnifica from near Sydney, New South Wales, has been studied in detail (Common and Edwards 1981). Adult female sun-moths possess a retractable ovipositor with which to 'deposit' eggs singly into the soil or sand at the base of the larval food plant. Upon hatching, the young larva then chews its way into the leaf bases and heads downwards to feed inside or beside the plant's rhizome and developing leaf shoots. Pupation takes place within an upright tubular structure, the top of which sits at or protrudes above ground level at the base of the food plant. The duration of life cycles may vary considerably depending on seasonal conditions, especially for those species which emerge in summer or autumn. For example, with $S$. gratiosa, small and medium sized larvae are often found at the same time as both adults and pupae. This indicates that larval duration may be anything from one to three years. In a pilot trial to translocate larval food plants, S. gratiosa food plants were potted and observed ex-situ. Although most of the plants died, the larvae they held survived for extended periods even after the plants had died - suggesting that larvae have the ability to remain quiescent for long periods (Williams M. et al. 2012).

\section{LARVAL FOOD PLANTS}

Typically it is the requirements of the immature life stages that define habitat quality for insects. For butterflies and day flying moths, the importance of how densely their host plants occur has been demonstrated both in Western Australia and elsewhere (Dennis et al. 2004; Dover et al. 2008). Because of this obligate dependence of sun-moths on suitable plants for breeding, the potential habitat is determined by the distribution of their host plants (Williams M. et al. 2012). In Western Australia sun-moths are known to breed on monocotyledons belonging to four plant families, the sedges (Cyperaceae), mat-rushes (Asparagaceae), cordrushes (Ecdeiocoleaceae) and grasses (Poacaeae). Of the 21 Western Australian sun-moths for which larval food 
plant data is available (Table 1), at least eleven use sedges (Cyperaceae), three use mat-rushes (Asparagaceae), two use cord-rushes (Ecdeiocoleaceae) and six use grasses (Poaceae). Where multiple plant species are used by one sun-moth species, they usually belong to the same plant family. The exception is $S$. obscurella, which uses both Ecdeiocoleaceae and Poaceae. For eight species the larval food plant has not been identified. The relations between the phylogeny of the Western Australian sun-moths and their choice of host plants will furnish an interesting study of how the moths and plants coevolved. There is a proposal that Chamaexeros fimbriata, the food plant for S. edwardsi, should be placed in the genus Lomandra (Greg Keighery, personal communication, 2016), in which case the three related sun-moths $S$. gratiosa, $S$. jcaria and $S$. edwardsi would all use food plants belonging to the same genus.

\section{TEMPORAL DISTRIBUTION}

The longer days and warming sunshine of spring appear to trigger the emergence of spring flying sunmoths in south-western Western Australia (Williams and Williams 2016b). In species which have an extensive north-south distribution, the northernmost populations always fly first. Only later, as the conditions in the south become warmer, do the southern populations begin to emerge. Synemon catocaloides is a typical example of this pattern: the sun-moths

TABLE $1 \quad$ Larval food plants of Western Australian sun-moths. (Sources: personal communication M.F. Braby, M. Peterson; personal observation E.D. Edwards, A.A.E. Williams, M.R. Williams.)

\begin{tabular}{|c|c|c|}
\hline Sun-moth species & Larval food plants & Plant family \\
\hline Synemon directa & Lepidosperma gladiatum, Lepidosperma tetraquetrum & Cyperaceae \\
\hline Synemon sp. 'Moirs Rock' & Lepidosperma sanguinolentum, Lepidosperma sp. & Cyperaceae \\
\hline Synemon sp. 'Victoria Rock' & Lepidosperma drummondii & Cyperaceae \\
\hline Synemon nupta & Lepidosperma rigidulum & Cyperaceae \\
\hline Synemon leucospila & Lepidosperma tenue & Cyperaceae \\
\hline Synemon sp. 'Mount Dale' & Mesomelaena tetragona & Cyperaceae \\
\hline Synemon sp. 'Bob Hay' & Mesomelaena preissii & Cyperaceae \\
\hline Synemon sp. 'Perth' complex & Mesomelaena pseudostygia & Cyperaceae \\
\hline Synemon sp. 'Leeman' & Schoenus lanatus & Cyperaceae \\
\hline Synemon sp. nr. discalis & Gahnia lanigera & Cyperaceae \\
\hline Synemon sp. 'Ravensthorpe' & Gahnia ancistrophylla & Cyperaceae \\
\hline Synemon gratiosa & Lomandra hermaphrodita, Lomandra maritima & Asparagaceae \\
\hline Synemon jcaria & Lomandra effusa & Asparagaceae \\
\hline Synemon edwardsi & Chamaexeros fimbriata & Asparagaceae \\
\hline Synemon catocaloides & Ecdeiocolea monostachya & Ecdeiocoleaceae \\
\hline Synemon obscurella & Ecdeiocolea monostachya & Ecdeiocoleaceae \\
\hline Synemon obscurella & Spartochloa scirpoidea & Poaceae \\
\hline Synemon nais & Austrostipa nitida & Poaceae \\
\hline Synemon austera & Chrysopogon fallax & Poaceae \\
\hline Synemon wulwulam & Chrysopogon setifolius & Poaceae \\
\hline Synemon phaeoptila & Chrysopogon latifolius (NT record) & Poaceae \\
\hline Synemon sp. 'Roper River' & Chrysopogon fallax, Chrysopogon pallidus (NT records) & Poaceae \\
\hline
\end{tabular}




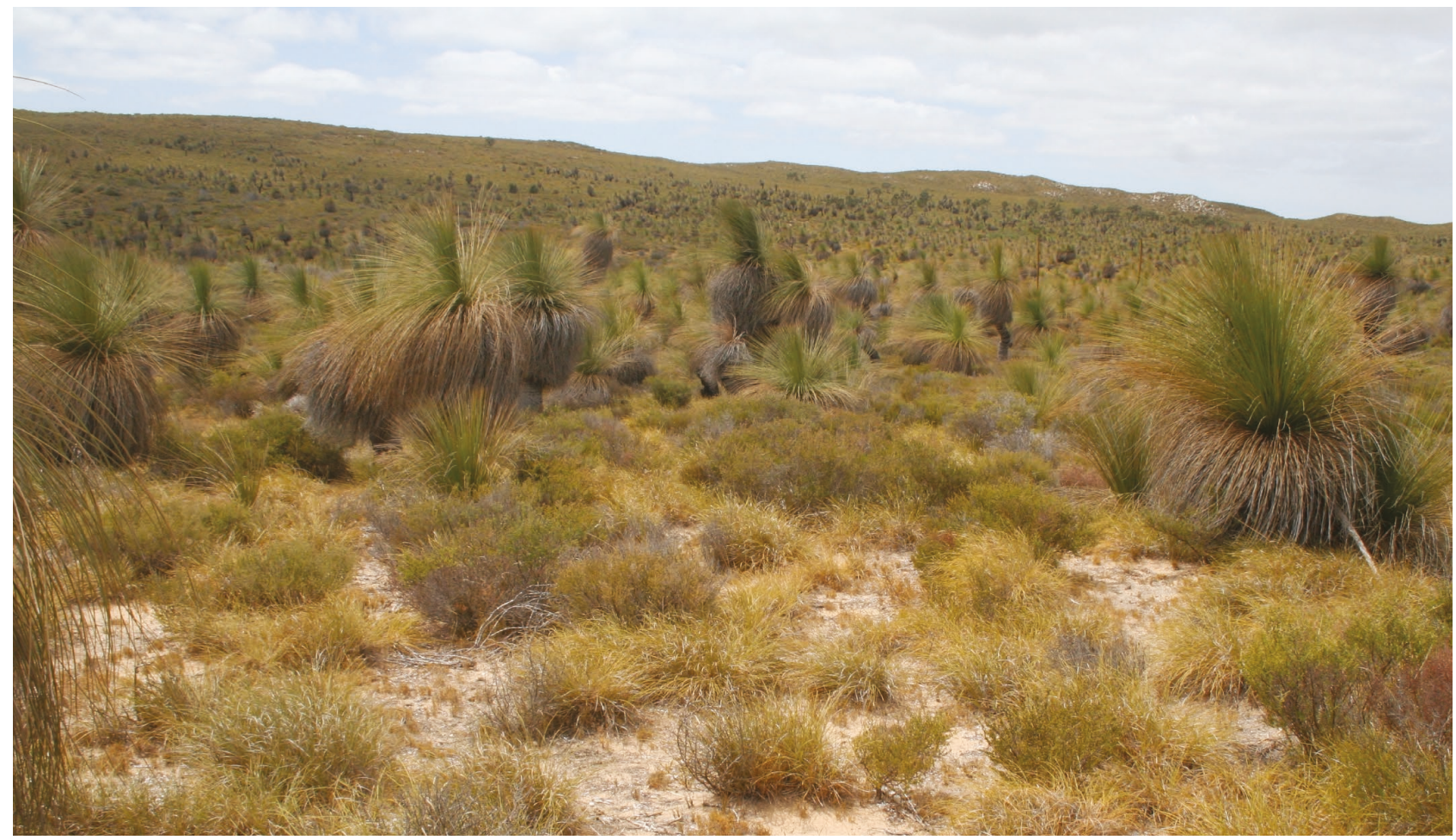

FIGURE 60 Wanagarren Nature Reserve (2014) showing grasstree (Xanthorrhoea preissii) woodland over tussocks of Lomandra maritima, the larval food plant of the graceful sun-moth Synemon gratiosa. (Photo: AndrewWilliams.)

at its northernmost sites emerge in August and early September, whereas those in the south do not fly until October. For the autumn flying S. gratiosa, which also has an extensive north-south distribution, the situation is reversed - only after the heat of summer has moderated do these sun-moths start to fly. Synemon gratiosa occurs from the south coastal town of Binningup to Murchison House Station near Kalbarri, $600 \mathrm{~km}$ to the north. Unlike the spring flying species, the first $S$. gratiosa emerge at their southernmost sites, where shorter days with cooler temperatures are experienced first. At Binningup, S. gratiosa flies in early February, and the emergence of this species progresses northwards over time, so that at Murchison House Station individuals finally emerge in mid March to early April (Williams and Williams 2016b).

Seasonal weather may also influence the flight period of some species. For example, this is the case for $S$. edwardsi, which occurs in the central and southern Wheatbelt. Initial monitoring has shown that its flight period is only two weeks and that the timing of its emergence varies from year to year. In dry years it appears in early November, but in cooler, wetter seasons it does not fly until much later in the month (Williams and Williams 2013b).

\section{RESPONSE TO FIRE}

South-western Western Australia has a Mediterranean type climate, characterised by hot, dry summers and cool, wet winters. Hot summer wildfires occur regularly across the landscape, and over time a remarkable number of plant species have evolved the ability to survive in this fire-prone environment (Hopper and Gioia 2004). The same is true for the local Castniidae fauna, whose life-cycles are particularly well suited to coping with the effects of fire.

Most Australian Lepidoptera have larvae which feed above ground on the leaves, shoots and flowers of various plants. This is not so with the Australian Castniidae: their immature stages develop underground, within the root rhizomes of their various monocotyledon food plants. Hence at least some species are known to be able to survive the passage of a fire. This has been observed at Landsdale Conservation Reserve, an isolated patch of native bushland within Perth's northern suburbs. This area of Banksia woodland was entirely burnt in January 2009. The following year adult graceful sun-moths $S$. gratiosa were nonetheless present on the reserve (David Pyke, personal communication, 2010). Synemon gratiosa has been recorded flying there each year since that time (A.A.E. Williams, personal observations, 2011-2016). In January 2016 a large proportion of Wanagarren Nature Reserve, $130 \mathrm{~km}$ north-north-west of Perth, was burnt in a hot summer wildfire. Subsequent monitoring along preestablished transects in Wanagarren Nature Reserve revealed that $S$. gratiosa had survived the fire. Freshly emerged adults were observed flying well within the scorched landscape, only a month after the fire, in early February 2016 (A.A.E. Williams and R.A.M. Coppen, personal observation, 2016) (Figures 61-62). 


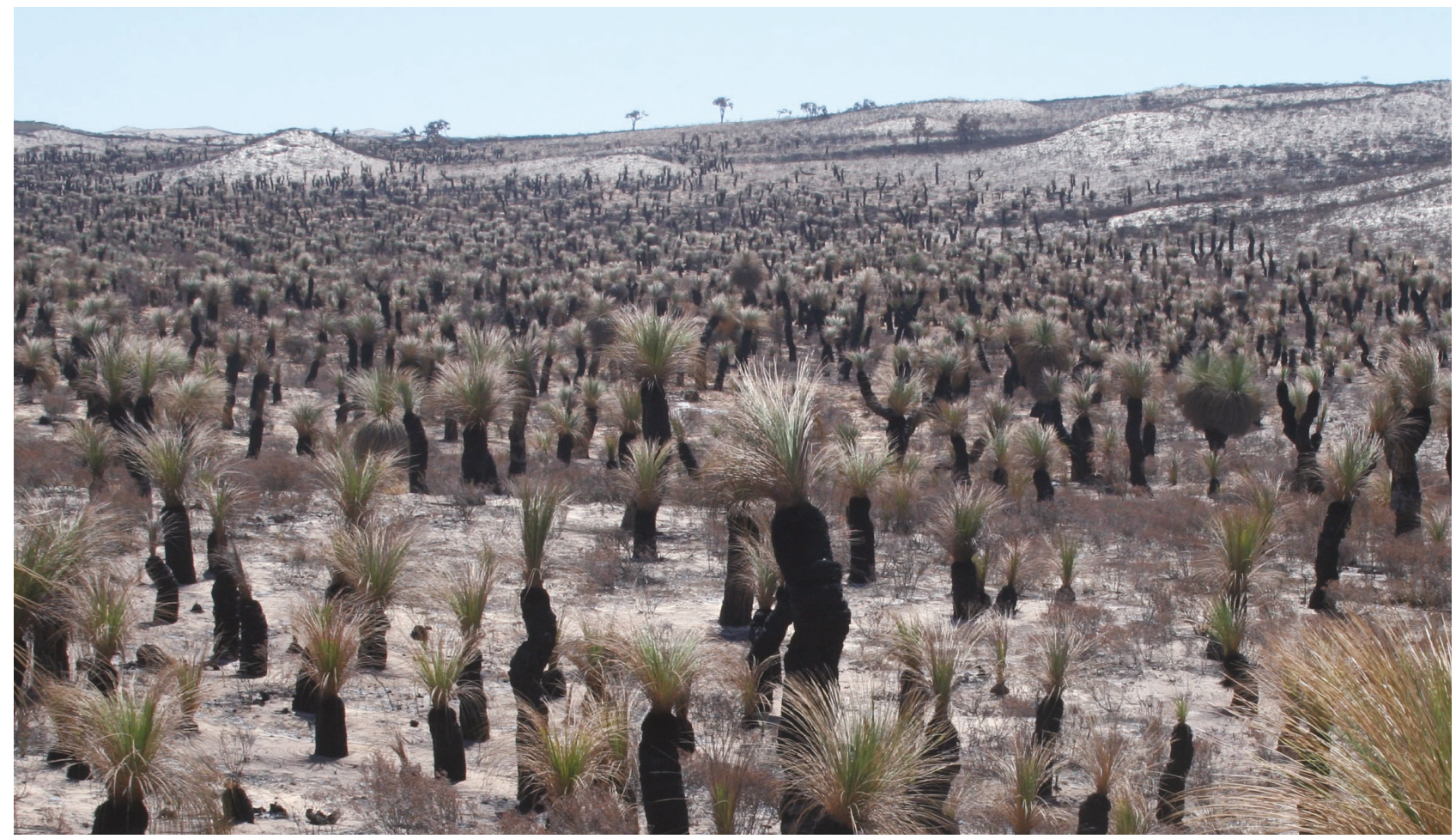

FIGURE 61 Wanagarren Nature Reserve after the summer wildfire in January 2016. (Photo: Andrew Williams.)

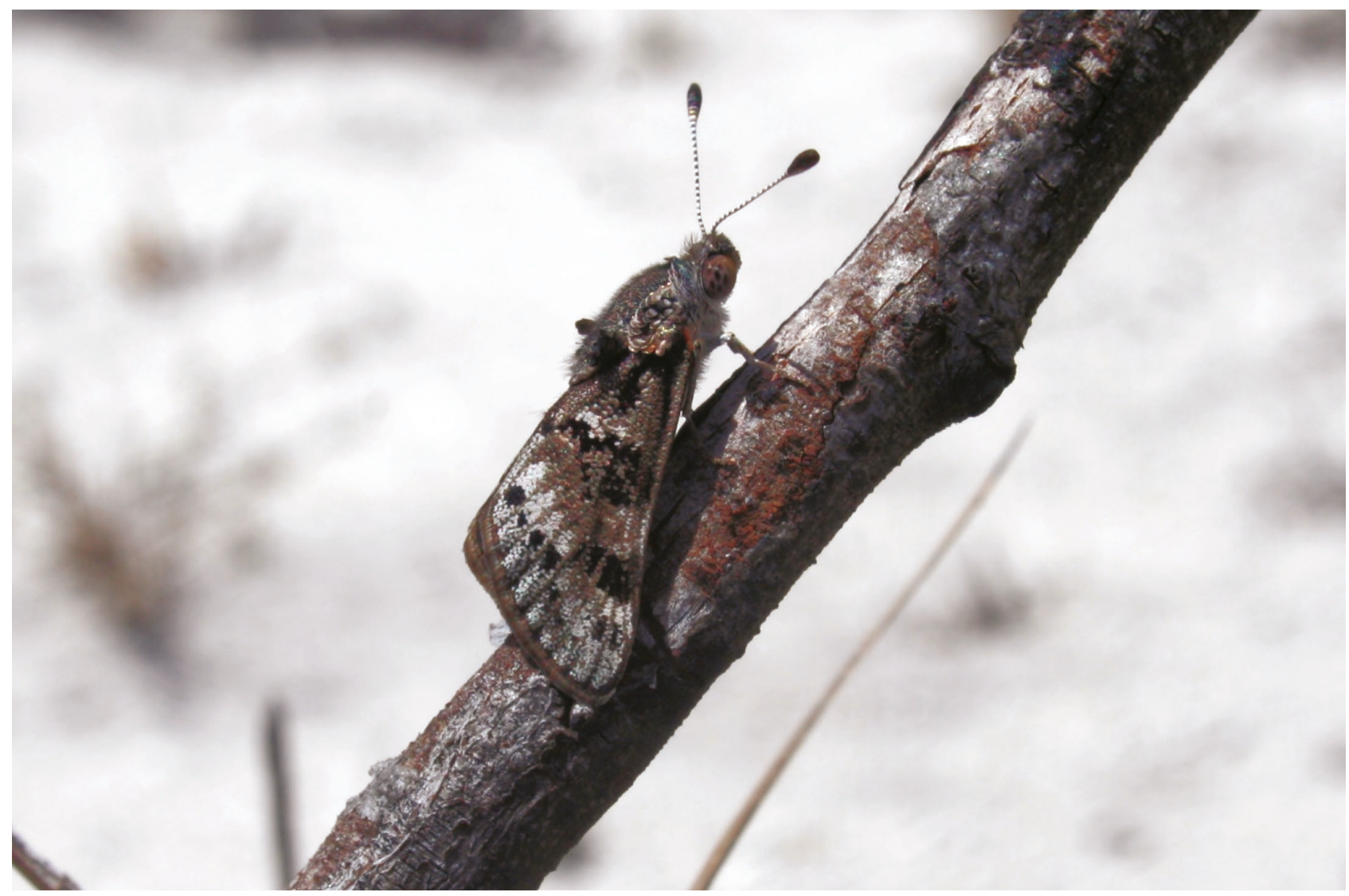

FIGURE 62 Freshly emerged S. gratiosa perched on a partially scorched shrub stem within the burnt portion of Wanagarren Nature Reserve (March 2016). Note the raised 'shoulder tufts' so characteristic of this sun-moth species group. (Photo: Andrew Williams.) 
In late December 2010, another Castniidae species, $S$. sp. 'Mount Dale', was locally abundant in a recently burnt area in the Jarrah (Eucalyptus marginata) and Marri (Corymbia calophylla) forest inland from Perth. Regenerating Mesomelaena tetragona sedges (the sunmoth's larval food plant) were numerous amongst the recovering understory plants. Sun-moths often flourish in freshly burnt areas, perhaps because for a period these are effectively 'fire-safe zones'. It is therefore possible that the forest dwelling Castniidae benefitted during the period when Aboriginal patchwork burning took place, prior to European settlement.

Also very interesting is the response to fire of $S$. sp. 'Perth', particularly in areas where $S$. sp. 'Perth' and $S$. sp. 'Yarloop' coexist. In the Perth metropolitan area, $S$. sp. 'Perth' normally flies in November. However, after a fire, it emerges much earlier than normal, and may be abundant in October; in newly burnt areas, $S$. sp. 'Perth' temporarily displaces $S$. sp. 'Yarloop', which round Perth is normally the first spring flying sun-moth to appear. Similar altered flight-time emergence has been noted in Badgingarra National Park, $175 \mathrm{~km}$ north of Perth. In October 2009, a freshly burnt protective firebreak, 200 metres wide, had been installed in bushland immediately west of Badgingarra townsite. Within this burnt area $S$. sp. 'Perth' was abundant in October 2009. Synemon sp. 'Yarloop' was not encountered in the burnt area, but was present in adjacent unburnt bushland and along a slashmowed (unburnt) perimeter beyond the town's newly burnt firebreak.

The ability of sun-moths to survive fire is not confined to southern species. At Limmen National Park in the Northern Territory, Braby (2011) recorded freshly emerged $S$. sp. 'Roper River' in an area where their grassland habitat had been extensively burnt three days earlier.

\section{HILL-TOPPING BEHAVIOUR}

Synemon sp. 'Mount Ragged' is a remarkably strong flier. It is the only Australian sun-moth known to exhibit deliberate hill-topping behaviour (see Common and Waterhouse 1981 pp. 59-62). Hill-topping behaviour has been reported for $S$. jcaria (Douglas 2007), but this is based on one observation by O.F. Noelker in February 1993. O.F. Noelker reportedly saw four male $S$. jcaria 'hill-topping' on a large sand-hill in the Big Desert, Victoria. On a subsequent visit to this site, Fabian Douglas and Allen Sundholm observed one male $S$. jcaria defending a confined territory at the top of the hill, noting the behaviour it exhibited was very similar to normal $S$. jcaria territorial behaviour in the Big Desert (Douglas 2007, p. 124). We consider it likely that O.F. Noelker's observation was nothing more than S. jcaria males competing for territory. Synemon gratiosa is closely related to $S$. jcaria. In Western Australia, it is not uncommon to find up to three $S$. gratiosa males on a single sandhill, each defending a discreet territory on the upper slopes round the summit of the hill. In these instances, periodic spiralling flights by two, three or even four males are commonplace. In Western Australia S. jcaria has not been recorded on large sandhills, but the species is regularly found on low sand ridges where males actively patrol and defend small territories. On the Evanston-Menzies Road west of Menzies, S. jcaria males have also been observed in territorial combat flights over patches of the larval food plant, L. effusa, along the edge of a small saline lake (A.A.E. Williams, personal observation, 2016).

\section{THREATS TO THE SURVIVAL OF WESTERN AUSTRALIAN SUN-MOTH SPECIES}

In Western Australia, the vast majority of the sunmoths (24 of the 29 species) are found in the southwestern part of the State (Figure 63). Many occur in what is now the Western Australian 'Wheatbelt' - a region dominated by broadscale agriculture, and almost completely cleared of natural vegetation. Prior to European settlement, this region must have supported an astoundingly diverse flora (see Keighery and Keighery 1981), and the invertebrate fauna would have been equally diverse. An indication of this may be deduced from the fact that relatively small bushland remnants (such as Wyalkatchem Nature Reserve) still retain as many as six sun-moth species (Williams and Williams 2013a). There is no evidence that any of the Western Australian sun-moths have become extinct since European settlement. For many sun-moth species, however, clearing and fragmentation of habitat have no doubt reduced both the extent of their occurrence and the area of occupied habitat.

For one Western Australian endemic species, the graceful sun-moth ( $S$. gratiosa), the impacts of habitat loss have been quantified and mapped. The detailed studies of this species (Williams M. et al. 2012), and of the golden sun-moth (Synemon plana) in eastern Australia (ACT Government 1998, Gibson and New 2007, DEWHA 2009a, 2009b), serve as examples that are likely to reflect the patterns of habitat loss of most other sun-moths. For these two species, the clearing of habitat has fragmented their previously continuous distributions. These remnant populations are now isolated from one another and, because of the moths' poor dispersal abilities, are potentially at risk of extinction. Synemon gratiosa has already become locally extinct at several sites where it was previously known to occur (Williams M. et al. 2012).

The past and ongoing loss and degradation of habitat, and the resultant fragmentation of that which remains, will have important and perhaps dire consequences for sun-moth populations and even entire species. Western Australia is not alone in this regard: in South America, the ongoing destruction of native habitat means that several giant butterfly-moth species (also Castniidae) may now be threatened or declining (Gonzáles 2004; Ríos and Gonzáles 2011). 
Habitat destruction from urban development particularly threatens those Western Australian sunmoths (and butterflies) which have coastal or near coastal distributions (Williams M. 2009). In the case of $S$. gratiosa, land clearing is projected to lead to the loss of $15-20 \%$ of its entire population within ten years (Williams M. 2012). Moreover, much of the Swan Coastal Plain round Perth is very fragile, being made up of vegetated sand dunes of varying ages (Seddon 1972). The species rich heathland and sedgeland on these sandy soils are very easily disturbed, allowing invasive exotics (especially the veldt grasses Ehrharta calycina Sm. and Ehrharta longiflora Sm.) to become established and out compete the native plants. This includes the native monocotyledons upon which Castniidae depend.

Even where relatively large tracts of urban bushland have been set aside for conservation or recreation, inappropriate management has at times had damaging consequences for sun-moths. For example, at Whiteman Park, north of Perth, overgrazing by uncontrolled numbers of western grey kangaroos (Macropus fuliginosus) in the Banksia woodland has depleted the larval food plant of $S$. gratiosa to such an extent that the sun-moth no longer survives there. At Bold Park, physical disturbance of the fragile sandy dune soils, where Lomandra maritima is still present, has allowed invasive veldt grasses to dominate the native plant understory. Previously open spaces between $L$. maritima larval food plants have now been occupied by dense veldt grasses. The result is that the open sandy patches where male $S$. gratiosa would normally establish territories have now gone. The habitat no longer supports graceful sun-moths (A.A.E. Williams, personal observation, 2011).

Perth's rapid population growth in recent years has resulted in greatly increased recreational use of off-road vehicles and motorbikes in the State forests inland of the city. In the last five years considerable damage has been inflicted on winter-wet areas within the forest. These seasonal forest wetlands are important habitat for a number of Castniidae, and Brachodidae day flying moths; if this uncontrolled recreational activity continues unabated, then irremediable damage to some seasonal wetland-dependant invertebrate populations is inevitable.

Along some of the fresh-water streams on the Darling Scarp, particularly in built-up areas, the introduced Bugle Lily (Watsonia meriana var. bulbillifera) is a serious invasive weed. This species has choked out native stream-line plants including the once dominant native sedge Lepidosperma tetraquetrum. As this sedge is a larval food plant for $S$. directa, the local extinction of the sedge equates to a corresponding loss of breeding habitat for the sun-moth.
In the semi-arid zone $S$. sp. 'Victoria Rock' is found on granite outcrops where its food plant $L$. drummondii survives, relying on the seasonal run off of rainfall from the rocks. In many cases, long water catchment barriers made from slabs of exfoliated stone have been cemented on the rocks to channel water into dams or reservoirs. As a result, water run off previously available to the fringing vegetation has been reduced, diminishing the abundance and quality of the sun-moth's larval food plant. In northern Western Australia large cattle stations will most likely continue to degrade habitat where sunmoths may still exist. Cattle trampling and grazing pressure on ribbon grassland habitat along watercourses in the Gascoyne region are likely to be a threat to the survival of $S$. austera.

Climate change is projected to bring a drying trend across south-western Western Australia, with forecasts of less predictable rainfall and greater aridity (Indian Ocean Climate Initiative 2012). This change has been identified as a potential threat for $S$. edwardsi, particularly in the northern parts of its range, where it occurs in isolated bushland remnants in the Wheatbelt (Williams and Williams 2013b). In time, $S$. gratiosa may also be threatened, if the drying climate reduces the density of its larval food plant, Lomandra hermaphrodita, in the Banksia woodlands round Perth. Rapid die-off of previously healthy large food plants has been noted in years of below-average winter rainfall, with no evidence of recruitment of young plants. (A.A.E. Williams, personal observations, 2010-2016). This drying trend and its overall effects on the vegetation of the Swan Coastal Plain have been well documented by Froend et al. (2011). The full impact of climate change on the larval food plants of the Western Australian Castniidae is yet to be experienced. Because sun-moths have an obligate dependence on specific plants for breeding, the distribution and health of these native food plants are crucial for their survival. If sunmoth larval food plants suffer or are unable to persist because of changing weather patterns, then the sun-moth populations will inevitably decline or disappear. Only Synemon plana, at western Belconnen in Canberra, $\mathrm{ACT}$, is known to have adapted to an introduced exotic grass as an alternative larval food plant (Braby and Dunford 2006).

\section{FUTURE CONSERVATION}

The conservation status 'not threatened' is proposed for eleven of the 29 Castniidae species recognised in this paper: S. catocaloides, S. leucospila, S. nupta, $S$. sp. 'Bob Hay', S. sp. nr. discalis, S. sp. 'Perth', S. sp. 'Yarloop', S. directa, S. sp. 'Mount Dale', S. jcaria. S. obscurella. Twelve species, S. sp. 'Leeman', S. maja, S. sp. 'Victoria Rock', S. notha, S. sp. 'Moirs Rock', $S$. sp. 'Mount Ragged', S. sp. 'Ravensthorpe', S. edwardsi, S. nais, S. phaeoptila, S. wulwulam, S. sp. 'Roper 
River' are considered 'data deficient', while five, $S$. sophia, S. austera, S. brontias, S. sp. 'Alan Graham' and $S$. sp. 'Eradu' are considered 'data deficient possibly endangered'. One species, S. gratiosa, is listed Federally as 'near-threatened' and as a 'priority 4' species under Western Australian State legislation (Williams M. 2012). This is the only Western Australian sun-moth species for which comprehensive survey work has been completed, and currently the Department of Parks and Wildlife is monitoring selected populations of this species from Binningup in the south to Kalbarri in the north.

For those sun-moth species listed in this paper as 'not threatened', regular monitoring of their presence or absence at selected sites is nonetheless important. For the twelve species listed as 'data deficient', further surveys are essential to determine their distributions accurately, and where possible identify their larval food plants, so that any potential vulnerability can be assessed. The five rarest and least known species, which are listed as 'data deficient - possibly endangered', require dedicated searches for new populations. Priority should be directed towards them. Studies are needed to determine their larval food plants in order to formulate effective conservation management plans. The responsible authority for the conservation and management of Western Australia's flora and fauna is the Department of Parks and Wildlife.

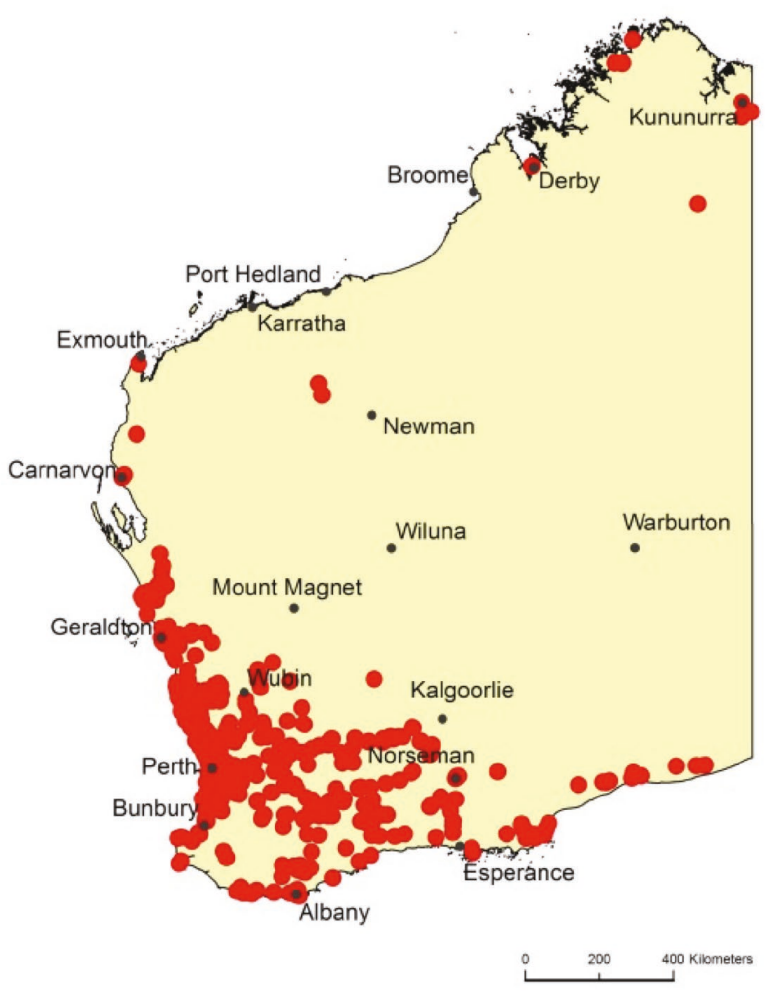

FIGURE 63 Map of Western Australia showing the concentration of Castniidae in the southwestern region.
As it is likely that many sun-moth species will be increasingly threatened in the future, it would seem desirable to promote public awareness of them and their needs, and to involve interested members of the public in research and management projects (for instance, growing known or suspected food plants) on public or private land. Such involvement could provide information relevant to the formulation of effective conservation management plans, such as the feasibility of protecting sun-moth populations by expanding their habitat, and perhaps the abilities of some of the sunmoth species to disperse and colonise new sites.

\section{ACKNOWLEDGEMENTS}

We are grateful to Brian Hanich and Nikolai Tatarnic (Western Australian Museum) who photographed the majority of sun-moth specimens illustrated in this paper. You Ning Su (CSIRO, Canberra) provided photographs of a number of specimens in the Australian National Insect Collection which are not well represented in the Lepidoptera reference collection of the Department of Parks and Wildlife in Perth. We are indebted to Michael Braby for his revision of an early draft manuscript, for providing photographic illustrations of Synemon sp. 'Roper River', for providing specimens of $S$. phaeoptila from the Northern Territory, and for his opinion on possible affiliations between Northern Territory and Kimberley S. phaeoptila. Fabian Douglas provided encouragement and valuable insights into differences between Synemon discalis from Victoria, and a related species, Synemon sp. $\mathrm{nr}$ discalis from Western Australia. We are also indebted to Jane Emberson and Robert Powell for their valuable suggestions on the final draft. We thank Fred and Jean Hort for collecting many sun-moth specimens and locating the unusual hybrid population of Synemon gratiosa / Synemon jcaria in Wandoo National Park east of Perth. We are grateful to Terry Houston, Magnus Peterson, Paul Hutchinson, and Tony Tomlinson for permission to list their sun-moth records in this paper. We thank Doug Hilton, Axel Kallies, Cliff Meyer, Grant Miller and Steve Brown for the additional specimens they have provided for the Department of Parks and Wildlife Lepidoptera reference collection. Fabian Douglas kindly provided specimens of $S$. discalis from eastern Australia for genetic comparison with S. sp. nr. discalis specimens from Western Australia. We are grateful to Geoff and Lois Walker, who located a colony of $S$. wulwulam near Lake Argyle, and to J. Koeyers, who obtained the first $S$. phaeoptila specimens in Western Australia. Greg Keighery (Department of Parks and Wildlife) and Russell Barrett (Kings Park, Perth) identified the sun-moth larval food plant sedges, mat-rushes and grasses listed in this paper. 


\section{REFERENCES}

ACT Government (1998). Golden sun moth (Synemon plana). An endangered species. Action Plan No. 7, Environment ACT, Canberra, AU.

Angel, F.M. (1951). Notes on the Lepidoptera of the Northern Territory of Australia, with description of a new species. Transactions of the Royal Society of South Australia 74: 6-14, 1 plate.

Atlas of Living Australia, Castniidae. Accessed 27 November 2014: http://bie.ala.org.au/species/urn:lsid:biodiversity.org/.

Bishop, C., Williams, M., Mitchell, D., and Gamblin, T. (2010a). Survey guidelines for the graceful sun-moth (Synemon gratiosa) and site habitat assessments. Department of Environment and Conservation, Kensington, WA. 20 pp.

Bishop, C., Williams, M., Mitchell, D., Williams, A., Fissioli, J. and Gamblin, T. (2010b). Conservation of the graceful sunmoth (Synemon gratiosa): findings from the 2010 graceful sun-moth surveys and habitat assessments across the Swan, South West and southern Midwest regions: interim report, August 2010. Department of Environment and Conservation, Kensington, WA. 30 pp.

Braby, M.F. (2000). Butterflies of Australia: their identification, biology and distribution. CSIRO Publishing, Collingwood. 976 pp.

Braby, M.F. (2004). The complete guide to butterflies of Australia. CSIRO Publishing, Collingwood, Victoria, Australia. 339 pp.

Braby, M.F. and Dunford, M. (2006). Field observations on the ecology of the golden sun moth, 'Synemon plana' Walker (Lepidoptera: Castniidae). The Australian Entomologist 33: $103-110$.

Braby, M.F. (2011). New larval food plant associations for some butterflies and diurnal moths (Lepidoptera) from the Northern Territory and eastern Kimberley, Australia. The Beagle, Records of the Museums and Art Galleries of the Northern Territory 27: 85-105.

Braby, M.F. (2015). New larval food plant associations for some butterflies and diurnal moths (Lepidoptera) from the Northern Territory and eastern Kimberley, Australia. Part II. Records of the Western Australian Museum 30: 73-97.

Braby, M.F. (2016). The complete field guide to butterflies of Australia (second edition). CSIRO Publishing, Clayton South, Victoria. 384 pp.

Common, I.F.B. and Waterhouse, D.F. (1981). Butterflies of Australia. Revised Edition. Angus and Robertson, Sydney.

Common, I.F.B. and Edwards, E.D. (1981). The life history and early stages of Synemon magnifica Strand (Lepidoptera: Castniidae). Journal of the Australian Entomological Society 20: 295-302.

CSIRO, Australian National Insect Collection Taxon Database, Castniidae. Accessed 27 March 2014: http://anic.ento.csiro. au/database/biota_details.aspx?BiotaID=26617.

Dennis, R.L.H., Hodgson, J.G., Grenyer, R., Shreeve, T.G. and Roy, D.B. (2004). Host plants and butterfly biology. Do host-plant strategies drive butterfly status? Ecological Entomology 29: 12-26.

DEWHA (2009a). Background paper to EPBC Act Policy Statement 3.12 - Nationally Threatened Species and Ecological Communities: Significant impact guidelines for the Critically Endangered Golden Sun Moth (Synemon plana), by DEWHA, Department of the Environment Water Heritage and the Arts, Canberra.

DEWHA (2009b). Significant impact guidelines for the critically endangered golden sun moth (Synemon plana).
Department of the Environment Water Heritage and the Arts, Canberra

Douglas, F. (2004). Five threatened Victorian sun-moths Synemon species. Action Statement, Flora and Fauna Guarantee Act 1988, Victoria. No. 146, 11 pp.

Douglas, F., MSc. (2007). The Sun-moths (Lepidoptera: Castniidae) of Victoria, with a detailed study of the Pale Sun-moth (Synemon selene Klug, 1850). University of Ballarat, Victoria.

Douglas, F. (2012). Orange sun-moth (Synemon nais) survey in the Victorian Mallee. Mallee Catchment Technical Bulletin No. 10.4 pp.

Dover, J.W., Dennis, R.L.H. and Atkins, L. (2008). The western jewel butterfly (Hypochrysops halaetus) II: factors affecting oviposition and egg distribution within native Banksia bushland in an urban setting. Journal of Insect Conservation 13: 487-503.

Edwards, E. D. (1997). Moths in the sun. ANIC News 10: 7-8.

Edwards, E.D., Gentili, P., Horak, M., Kristensen, N.P. and Nielsen, E.S. (1999). The cossoid/sesioid assemblage. Ch. 11, pp. 181-195 in Kristensen, N.P. (Ed.). Lepidoptera, Moths and Butterflies. Volume 1: Evolution, Systematics, and Biogeography. Handbuch der Zoologie. Eine Naturgeschichte der Stämme des Tierreiches / Handbook of Zoology. A Natural History of the phyla of the Animal Kingdom. Band / Volume IV Arthropoda: Insecta Teilband / Part 35: 491 pp. Walter de Gruyter, Berlin, New York.

Felder, C., Felder, R. and Rogenhofer, A.F. (1864). Reise der Österreichischen Fregatte Novara um die Erde in den Jahren 1857, 1858, 1859. Kaiserlich-Königliche Hof- und Staatsdruckerei, Vienna, plate 79.

Felder, R. (1874). 'S. Icaria' In: Histoire naturelle des insectes. Species général des lépidoptères héterocères (Eds.), J.A Boisduval and A. Guenée, Librarie Encyclopedique de Roret, Paris, pp. 554-55.

Florabase: Western Australian Herbarium (1998-). FloraBase - the Western Australian Flora. Department of Parks and Wildlife: https://florabase.dpaw.wa.gov.au/

Froend, R., Hardy, G., Matusick, G., Poot, P. and Venrklaas, E. (2011). Effects of drought on our south-west bushland. Bushland News 78: pp. 1 and 5.

Gamblin, T., Bishop, C., Williams, M. and Williams, A. (2010). Graceful sun-moth. Landscope 25(4): 31.

Gamblin, T., Bishop, C., Williams, M. and Williams, A. (2011). Graceful sun-moth (Synemon gratiosa). Information Sheet 41, 2pp. Accessed: http://www.dpaw.wa.gov.au/aboutus/science-and-research/publications-resources/111-sciencedivision-information-sheets/.

Gibson, L. and New, T.R. (2007). Problems in studying populations of the golden sun-moth, Synemon plana (Lepidoptera: Castniidae), in south eastern Australia. Journal of Insect Conservation 11: 309-313.

Gonzáles, J.M. (2004). Castniinae (Lepidoptera: Castniidae) from Venezuela. VI. The genus Athis. Diagnosis and comments. Caribbean Journal of Science 40: 408-413.

Grund, R, (2011). A new species of Synemon Doubleday (Lepidoptera: Castniidae) from the Colona Plains, South Australia. The Australian Entomologist 38: 167-178.

Grund, R. (2011). South Australian sun-moths. Accessed: http:// sabutterflies.org.au/moths/S_nais.htm/.

Grund, R. and Stolarski, A. (2012). Taxonomy and biology of Synemon discalis Strand and S. parthenoides R. Felder (Lepidoptera: Castniidae) in South Australia. Australian Entomologist 39: 121-161. 
Hopper, S.D. and Gioia, P. (2004). The southwest Australian floristic region: evolution and conservation of a global hot spot of biodiversity. Annual Review of Ecology, Evolution and Systematics 35: 623-650.

ICZN (International Commission on Zoological Nomenclature) (1999). International Code of Zoological Nomenclature, 4th edition. Adopted by the I.U.B.S. The International Trust for Zoological Nomenclature, London.

Indian Ocean Climate Initiative (2012). Western Australia's Weather and Climate: A synthesis of Indian Ocean Climate lnitiative Stage 3 Research. (Eds.), Bates, B., Frederiksen, C. and Wormworth, J. CSIRO and Bureau of Meteorology, Australia.

Kallies A, Edwards T, Young A, Douglas F. (2016).Synemon ignita sp. nov., a new sun moth species from southern Australia (Lepidoptera, Castniidae). Zootaxa 4092(3): 436-44.

Keighery, G. and Keighery, B. (2014). The Avon wheatbelt: an underrated biodiversity hotspot. Kwongan Matters 4: 7-15.

Klug, J.C.F. (1850). Über die Lepidopteren-Gattung Synemon. Nebst einem Nachtrage über Castniae. Abhandlungen der Königlichen Akademie der Wissenschaften zu Berlin. pp. 245-257, 1 plate.

Meyrick, E. (1891). Descriptions of new Australian Lepidoptera, Transactions of the Royal Society of South Australia 14: 188-192.

Orr, A. and Kitching, R. (2010). The Butterflies of Australia. Allen \& Unwin. 336 pp.

Ríos, S.D. and Gonzáles, J.M. (2011). A synopsis of the Castnidae (Lepidoptera) of Paraguay, Zootaxa 3055: 43-61.

Seddon, G. (1972). Sense of Place. University of Western Australia Press. 274 pp.

Strand, E. (1911). Castniidae. In: Seitz, A. (Ed.) The Macrolepidoptera of the World. Volume 10, Bombyces and Sphinges of the Indo-Australian Region. Alfred Kernen, Stuttgart, 2 volumes. 909 pp, 100 plates.

Walker, F. (1865). List of the specimens of Lepidopterous Insects in the collection of the British Museum, Part XXXL Supplement 2: 322-706.

Westwood, J.O. (1877). A monograph of the Lepidopterous Genus Castnia and some allied groups. Transactions of the Linnean Society, Series 2, Zoology, Volume 1. London, pp. 155-207, plates 28-33.

White, A. (1841). Notes on some insects from King George's Sound, collected and presented to the British Museum by Captain George Grey. In Grey, G., Journals of two expeditions of discovery in north west and western Australia, during the years 1837, 38, and 39. Under the authority of Her Majesty's government, describing many newly discovered, important and fertile districts, with observations on the moral and physical character of the aboriginal inhabitants, \&c. \& c. T. and W. Boone, London, pp. $450-482$.

Williams, A., Powell, R., Williams, M. and Walker, G. (2009). Common Butterflies of the South-West. Department of Environment and Conservation, Kensington. Department of Environment and Conservation, Western Australia, Bush Books. 72 pp.

Williams, A.A.E. (2011). Report on Pilbara rare sun-moth survey, September 2011. Department of Environment and Conservation, Woodvale, Western Australia. 5 pp.

Williams, A., Williams, M., Powell, R. and Walker, G. (2012). Rare Butterflies of the South-West. Department of Environment and Conservation, Kensington. Department of Environment and Conservation, Western Australia, Bush Books. 72 pp.

Williams, A. and Williams, M. (2013a). Sun-moth haven in the wheatbelt: Wyalkatchem Nature Reserve. Landscope 28(4): pp. 24-30.

Williams, A.A.E. and Williams, M.R. (2013b). Kukerin sunmoth, Synemon sp. Kukerin, rediscovered. Information Sheet 67, 2pp. Accessed: http://www.dpaw.wa.gov.au/aboutus/science-and-research/publications-resources/111-sciencedivision-information-sheets/.

Williams, A.A.E. and Williams, M.R. (2016a). A new species of Synemon Doubleday (Lepidoptera: Castniidae) from Western Australia. Australian Entomologist 43: 119-134.

Williams, A.A.E. and Williams, M.R. (2016b). Castniidae Database (sorted by species / locality / date) July 2016. Department of Parks and Wildlife, Science and Conservation Division, Kensington, Western Australia. 66 pp.

Williams, M.R. (2009). Butterfly and day flying moths in a fragmented urban landscape, south-west Western Australia: patterns of species richness. Pacific Conservation Biology 15: $32-46$.

Williams, M. (2011). Graceful sun-moth results 2011. Bushland News 80: 5.

Williams, M. (2012). Graceful sun-moth - survey results. Western Australian Insect Study Society Newsletter. April 2012. pp. 3-6.

Williams, M., Bishop, C., Mitchell, D., Williams, A. and Gamblin, T. (2012). Conservation of the graceful sun-moth (Synemon gratiosa): survey results from the Swan, South West and southern Midwest regions 2010-2012: summary report. Department of Environment and Conservation, Western Australia. 16 pp.

MANUSCRIPT RECEIVED 29 AUGUST 2016; ACCEPTED 7 DECEMBER 2016. 